\title{
Dolomite flotation of high magnesium phosphate ores using fatty acid soap collectors
}

\author{
Zhengxing Gu \\ West Virginia University
}

Follow this and additional works at: https://researchrepository.wvu.edu/etd

\section{Recommended Citation}

Gu, Zhengxing, "Dolomite flotation of high magnesium phosphate ores using fatty acid soap collectors" (2007). Graduate Theses, Dissertations, and Problem Reports. 4303.

https://researchrepository.wvu.edu/etd/4303

This Dissertation is protected by copyright and/or related rights. It has been brought to you by the The Research Repository @ WVU with permission from the rights-holder(s). You are free to use this Dissertation in any way that is permitted by the copyright and related rights legislation that applies to your use. For other uses you must obtain permission from the rights-holder(s) directly, unless additional rights are indicated by a Creative Commons license in the record and/ or on the work itself. This Dissertation has been accepted for inclusion in WVU Graduate Theses, Dissertations, and Problem Reports collection by an authorized administrator of The Research Repository @ WVU.

For more information, please contact researchrepository@mail.wvu.edu. 


\title{
Dolomite Flotation of High Magnesium Phosphate Ores \\ Using Fatty Acid Soap Collectors
}

\author{
Zhengxing Gu
}

\author{
Dissertation submitted to \\ College of Engineering and Mineral Resources \\ at West Virginia University \\ in partial fulfillment of the requirements \\ for the degree of
}
Doctor of Philosophy
in
Mineral Processing
Felicia F. Peng, Ph.D., Chair
Syd Peng, Ph.D.
Eung Ha Cho, Ph.D.
Yi Luo, Ph.D.
Yunqing Zhang, Ph.D.

\section{Department of Mining Engineering}

Morgantown, West Virginia

2007

Key words: dolomitic phosphate, flotation, fatty acid, surfactants 


\section{ABSTRACT \\ Dolomite Flotation of High Magnesium Phosphate Ores \\ Using Fatty Acid Soap Collectors}

\section{Zhengxing Gu}

The separation of dolomite from apatite has been recognized as one of the most difficult subjects in mineral processing due to the similarities in their physiochemical properties. In this study, selective surfactants were used with a fatty acid soap collector to improve the flotation performance of separating dolomite from high magnesium phosphate ores.

Three surfactants, diethyl phthalate (DP), Tween-80 (TW) and derivative of sulfonate salt (DSS1) were used. Hallimond cell flotation was conducted using pure dolomite sample to determine the effects of various factors including dosages, particle size, $\mathrm{Ca}^{2+}$ ions and slimes on the dolomite flotation recovery. The results showed that the surfactants can significantly improve dolomite flotation performance by increasing collecting ability and tolerating the effect of calcium ions and slime contents.

The stirrer-tank cell batch flotation tests were carried out using two natural high magnesium phosphate ore samples containing 3.3\% and $1.5 \% \mathrm{MgO}$. The test results showed that the surfactant DP could improve dolomite flotation at low dosages, and DSS1 could enhance the separation of dolomite from phosphate by improving both 
collecting ability and flotation selectivity. When $10 \%$ of DSS1 was used with the fatty acid soap as collector, at least $10 \%$ more dolomite can be removed with less $\mathrm{P}_{2} \mathrm{O}_{5}$ loss. The effectiveness of the surfactant DSS1 in enhancing dolomite flotation was further demonstrated in modified packed column flotation with natural dolomitic phosphate ore sample.

The addition of the surfactant DSS1 into fatty acid soap collector could improve its frothability and froth stability, and reduce the bubble size. It has been found that the dolomite flotation performance has a close relationship with the frothability and froth stability of the collector. 


\section{ACKNOWLEDGEMENTS}

The author would like to express his deep appreciation to his academic advisor and dissertation committee Chair, Dr. Felicia F. Peng for her persistent guidance during the course of the research work. The valuable suggestions and comments by dissertation committee members, Dr. Eung Ha Cho, Dr. Syd Peng, Dr. Yi Luo and Dr. Yunqing Zhang are greatly appreciated.

Special acknowledge is due to the financial supports to this research projects (DE-FC26-01NT41091 WV006 and WV007) provided by the U.S. Department of Energy (U.S. DOE), National Energy and Technology Center (NETL), through the Center of Advanced Separation Technology (CAST). The fundings also support author in pursuing his Ph.D. in Mining Engineering, emphasized on mineral Processing. College of Engineering and Mineral Resources, West Virginia University is greatly acknowledged.

The author would also like to express his sincere thanks to Dr. Patrick Zhang, research director of Florida Institute of Phosphate Research, and Dr. Yichang Guan, process engineer of Mosaic Phosphate Company, for providing dolomitic phosphate samples, and technical advices. Dr. Guoxin Wang, technical manager of Arr-Maz Chemicals, is also acknowledged for providing flotation reagents.

The author wishes to give particular thanks to his wife, Xiaomei Wang, and his daughter, Jie Gu for their constant love and understanding, and to his family members in China for their consistent encouragement and moral support. 


\section{TABLE OF CONTENTS}

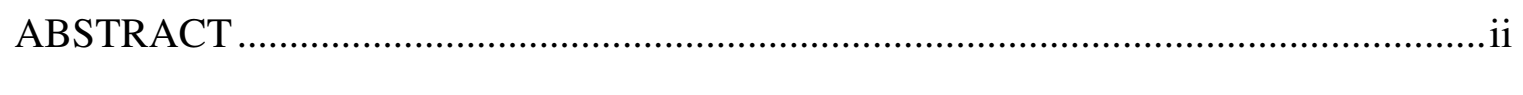

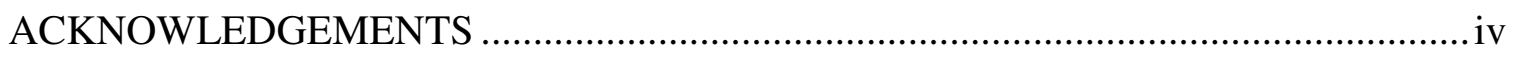

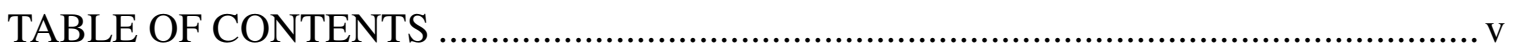

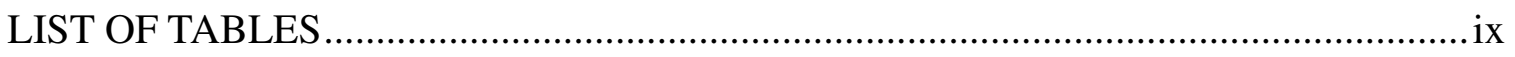

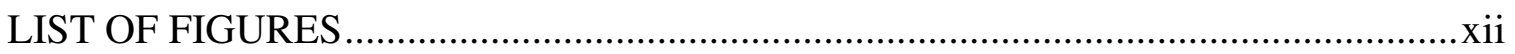

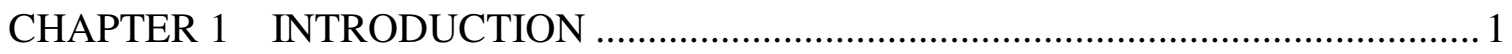

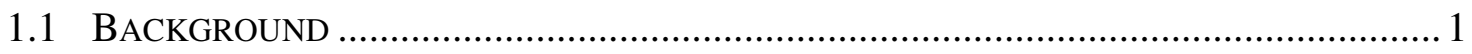

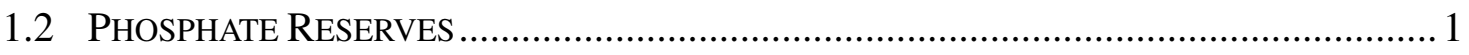

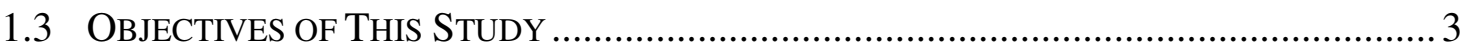

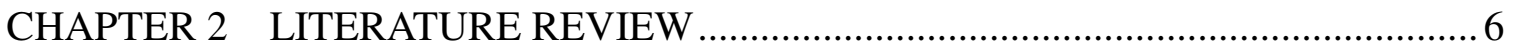

2.1 Similarity in Properties of CARbonate And Phosphate Minerals .................. 6

2.2 Development of Carbonate SeParation Processes ……................................ 7

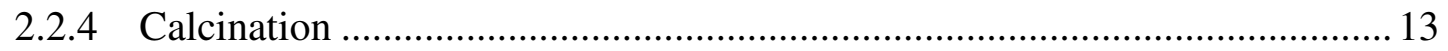

2.2.5 Physical Separation Methods .................................................................... 13

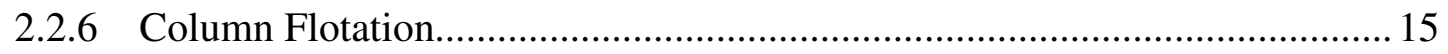

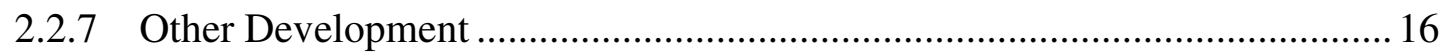




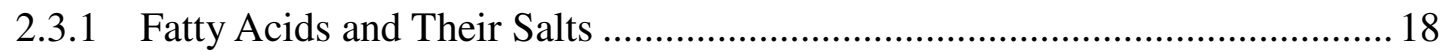

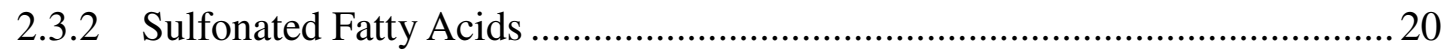

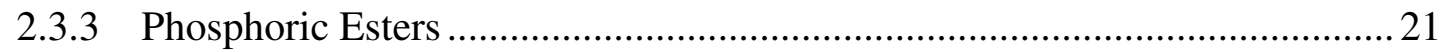

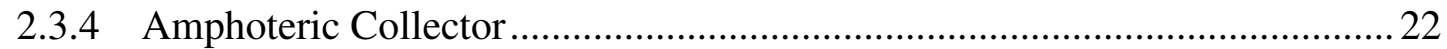

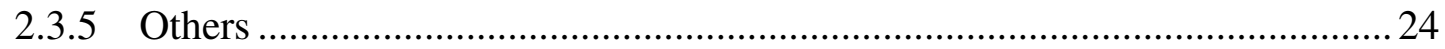

2.4 Flotation with Surfactant MiXtures as Collectors .................................. 25

2.5 MEChanisms of Dolomite Flotation in ACIDIC MEdiA .................................. 28

2.5.1 pH Effect on Dolomite Flotation.........................................................28

2.5.2 Mechanisms of Dolomite Flotation ..........................................................29

CHAPTER 3 MATERIALS AND METHODOLOGY ............................................... 33

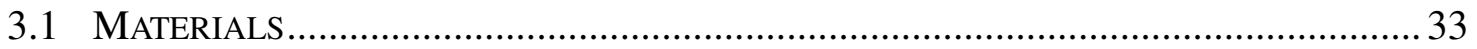

3.1.1 Phosphate Ore Samples and Compositions ............................................ 33

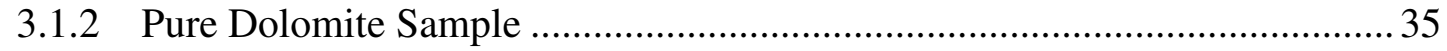

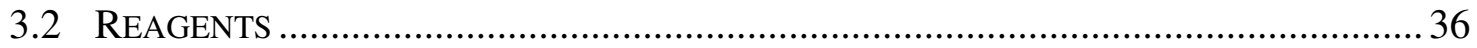

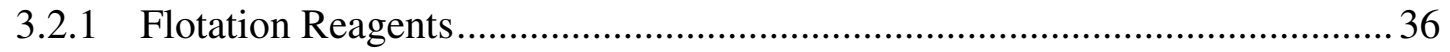

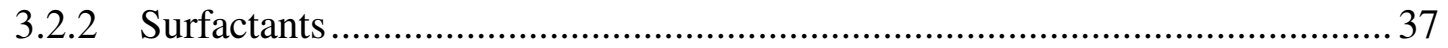

3.3 EQUIPMENT AND EXPERIMENTAL METHODS .................................................... 38

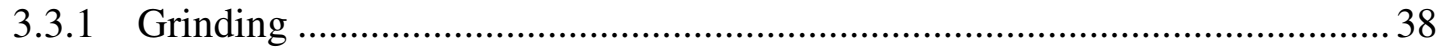

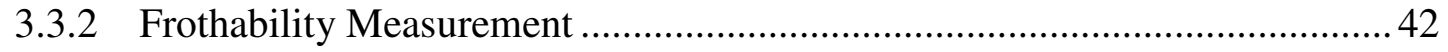


3.3.3 Froth Stability Measurement ......................................................................... 43

3.3.4 Hallimond cell flotation Experiments ............................................................ 44

3.3.5 Batch Flotation Experiments................................................................... 47

3.3.6 Modified Packed Column Flotation ...............................................................50

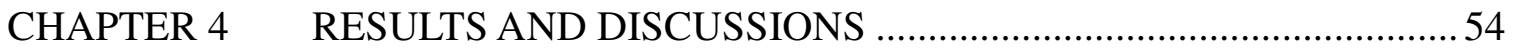

4.1 MEASUREMENT OF FrothabILITY AND Froth StABILITY ....................................54

4.1.1 Effect of Selected Surfactants on Collector Frothability ………...................54

4.1.2 Effect of Selected Surfactants on Collector Froth Stability ...........................66

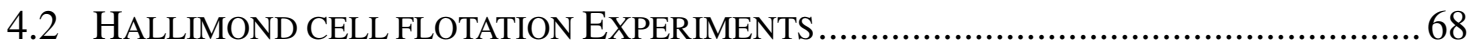

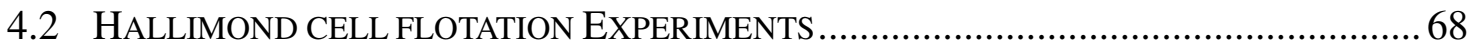

4.2.1 Effect of Reagent Dosages on Dolomite Flotation..........................................68

4.2.2 Effect of Calcium Ions on Dolomite Flotation............................................... 71

4.2.3 Effect of Particle Size on Dolomite Flotation ................................................

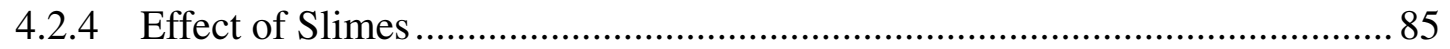

4.3 Batch Cell Flotation of Natural Dolomitic Phospahte Ores ..................... 92

4.3.1 pH Effect on Dolomite Flotation.................................................................92

4.3.2 Surfactant Effect on Dolomite Flotation for Sample H.................................. 99

4.3.3 Surfactant Effect on Silica Flotation ........................................................... 107

4.3.4 Surfactant Effect on Bubble Size …………….......................................... 109

4.3.5 pH Effect on Dolomite Flotation in Presence of DSS1 ................................. 112 
4.3.6 Flotation Tests on Dolomitic Phosphate Sample L .................................... 114

4.3.7 Dolomite Flotation Results with Different Dolomite Collectors ................. 118

4.4 Packed Column Flotation of Dolomitic Phosphate Ore ............................ 121

4.4.1 Experiment Design for Modified Packed Column Flotation ....................... 122

4.4.2 Grinding Tests for Modified Packed Column Flotation .............................. 125

4.4.3 Modified Packed Column Flotation Test Results..................................... 125

4.4.4 Modified Packed Column Flotation of Dolomitic Phosphate Ore With MiXTURE OF FAS-40A AND DSS1 AS COLLECTOR ................................................. 135

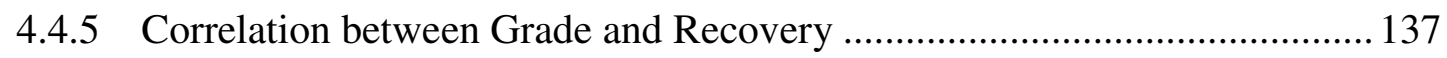

4.4.6 Amine Flotation to Remove Silica Impurity ........................................... 141

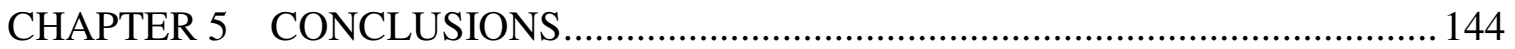

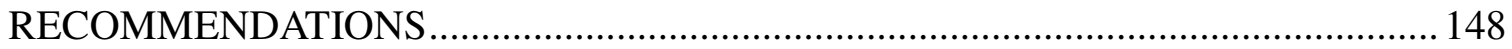

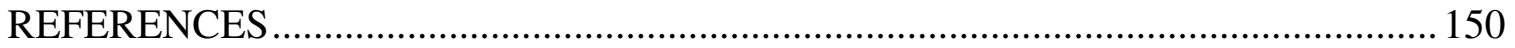

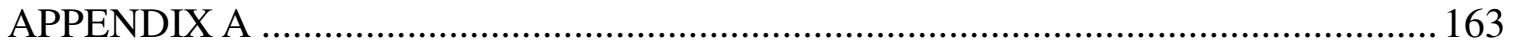

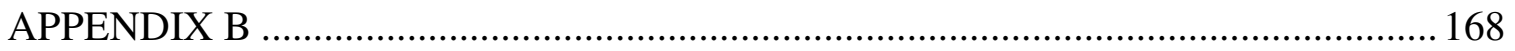

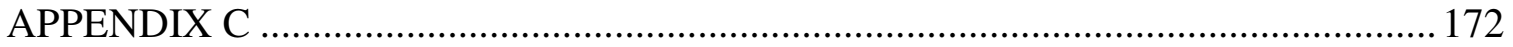

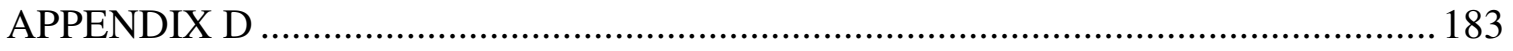

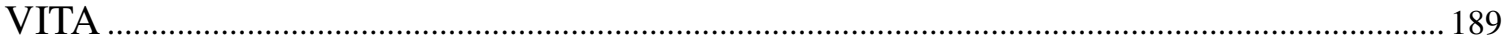




\section{LIST OF TABLES}

Table 1-1 World Phosphate Production, Reserves, and Reserve Base ........................... 2

Table 1-2 Summary of Process Developed for Florida Dolomitic Phosphate

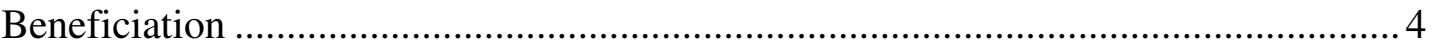

Table 3-1 Chemical analysis of dolomitic phosphate pebble samples ......................... 34

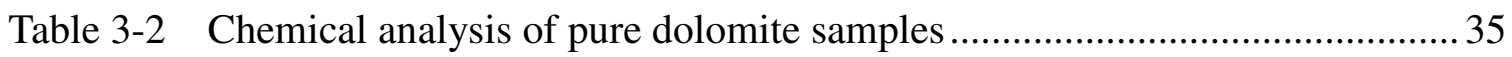

Table 3-3 Size distribution at different grinding time for $300 \mathrm{~g}$ dolomitic phosphate

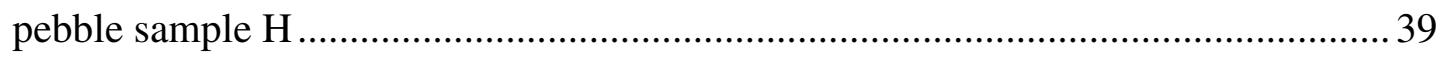

Table 3-4 Size distribution at different grinding time for $300 \mathrm{~g}$ dolomitic phosphate

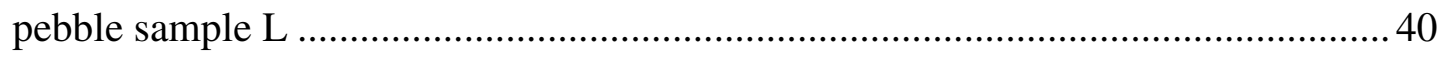

Table 3-5 Size distribution at different grinding time for $1000 \mathrm{~g}$ dolomitic phosphate

pebble sample L

Table 4-1 Ultimate froth height and volume constant as a function of froth

concentration

Table 4-2 Conditions for the modified packed column flotation

Table 4-3 Experiment design of column flotation tests

Table 4-4 Results of modified packed column flotation

Table 4-6 Sum of squares, F-ratios and p-values

Table 4-9 Packed column test results using FAS-40A collector and surfactant DSS1. 137

Table 4-10 Material balance of dolomite flotation followed by silica amine flotation 143 
Table A-1 Size distribution and chemical analysis of dolomitic phosphate pebble sample $\mathrm{H}$

Table A-2 Chemical analysis of the as-received sample $\mathrm{H}$ 165

Table A-3 Size distribution and chemical analysis after the sample was crushed to minus $1.18 \mathrm{~mm}$ (14 mesh) of sample $\mathrm{H}$ 165

Table A-4 Size distribution and chemical analysis of flotation feed of sample $\mathrm{H}$ (after the sample was ground in rod mill) 165

Table A-5 Size distribution and chemical analysis of dolomitic phosphate pebble sample L 166

Table A-6 Chemical analysis of the as-received dolomitic phosphate sample L 167

Table A-7 Size distribution after the sample was crushed to minus $1.18 \mathrm{~mm}$ (14 mesh) of sample L

Table A-8 Size distribution of flotation feed of sample L (after the sample was ground in $\operatorname{rod}$ mill)

Table B-1 Foam height as a function of airflow rate at various dosages of FAS-40A collector $(\mathrm{cm})$

Table B-2 Foam height as a function of airflow rate at various ratios of DSS1 to FAS-40A collector 169

Table B-3 Foam height as a function of airflow rate at various ratios of DP to FAS-40A collector 170

Table B-4 Foam height as a function of airflow rate at various ratios of TW to FAS-40A 
collector

170

Table B-5 Lifetime of foams produced by FAS-40A collector in the presence and absence of surfactants

Table C-1 pH effect on dolomite flotation 173

Table C-2 Effect of FAS-40A dosages on dolomite flotation in the absence of surfactants at $\mathrm{pH} 5.4$ 174

Table C-3 Effect of the ratio of DSS1 to FAS-40A on dolomite flotation .175

Table C-4 Effect of the ratio of DP to FAS-40A on dolomite flotation. 176

Table C-5 Effect of the ratio of TW to FAS-40A on dolomite flotation 177

Table C-6 Effect of FAS-40A dosages on dolomite flotation in the presence of surfactant DSS1 at $\mathrm{pH} 5.4$ 178

Table C-7 Effect of FAS-40A dosages on dolomite flotation in the presence of surfactant DP at $\mathrm{pH} 5.4$ 179

Table C-8 Effect of FAS-40A dosages on dolomite flotation in the presence of surfactant TW at $\mathrm{pH} 5.4$ 180

Table C-9 Effect of CCS-500 dosages on dolomite flotation at $\mathrm{pH} 5.1 \ldots \ldots \ldots \ldots \ldots \ldots . . . . . . . . . . .181$

Table C-10 Effect of CCS-500 dosages on dolomite flotation at $\mathrm{pH} 5.1$................... 181

Table C-11 Mixtures of FAS-40A and CCS-500 (or CCS-550) as collector at pH 5.1182

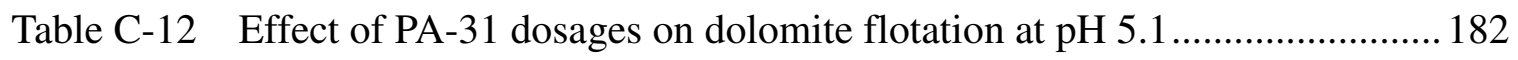

Table D-1 Results of modified packed column flotation ....................................... 184 


\section{LIST OF FIGURES}

Fig. 2-1 Flotation of francolite and dolomite as a function of $\mathrm{pH}$ by Xiao et al.

Fig. 3-1 Percentage passing as a function of grinding time for $300 \mathrm{~g}$ sample $\mathrm{H}$ 39

Fig. 3-2 Percentage passing as a function of grinding time for $300 \mathrm{~g} \mathrm{~B}$ sample. 40

Fig. 3-3 Percentage passing as a function of grinding time for $1000 \mathrm{~g} \mathrm{~B}$ sample. 41

Fig. 3-4 Illustration of complete Hallimond cell flotation assembly 46

Fig. 3-5 Schematic diagram of 2-in ID modified packed flotation column system ....... 52

Fig. 4-1 Froth height as a function of aeration rate at various FAS-40A dosage .57

Fig. 4-2 Froth height as a function of aeration rate at $0.4 \mathrm{~g} / \mathrm{l} \mathrm{AS-40A}$ with different percentage of DP 58

Fig. 4-3 Froth height as a function of aeration rate at $0.4 \mathrm{~g} / \mathrm{l} \mathrm{FAS-40A}$ with different percentage of TW

Fig. 4-4 Froth height as a function of aeration rate at $0.4 \mathrm{~g} / \mathrm{l}$ FAS-40A with different percentage of DSS1

Fig. 4-5 Froth height as a function of surfactant percentage 64

Fig. 4-6 Froth height as a function of the ratio of surfactant percentage 65

Fig. 4-7 Froth lifetime as a function of collector dosage measured at $11 / \mathrm{min}$. airflow

rate

Fig. 4-8 Dolomite recovery as a function of collector dosages in the presence and absence of surfactants 
Fig. 4-9 Dolomite recovery as a function of the ratio of the surfactant percentage to

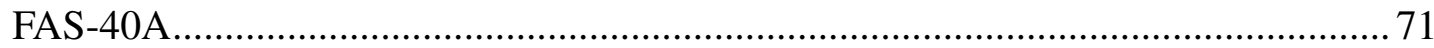

Fig. 4-10 Effect of calcium ions on dolomite flotation using FAS-40A as collector ..... 72

Fig. 4-11 Effect of calcium ions on dolomite flotation using mixture of FAS-40A and

$10 \%$ DSS1 as collector

Fig. 4-12 Effect of calcium ions on dolomite flotation using mixture of FAS-40A and $10 \% \mathrm{DP}$ as collector

Fig. 4-13 Effect of calcium ions on dolomite flotation using mixture of FAS-40A and $10 \%$ TW as collector 75

Fig. 4-14 Dolomite flotation recovery as a function of collector dosage at $100 \mathrm{ppm} \mathrm{ca}^{2+}$ in the presence and absence of surfactants .76

Fig. 4-15 Dolomite flotation recovery as a function of FAS-40A dosage for different size fractions 79

Fig. 4-16 Dolomite flotation recovery as a function of FAS-40A and 10\% DSS1 dosage for different size fractions 80

Fig. 4-17 Dolomite flotation recovery as a function of FAS-40A and 10\% DP dosage for different size fractions 81

Fig. 4-18 Dolomite flotation recovery as a function of FAS-40A dosage in presence of $10 \%$ TW for different size fractions 82

Fig. 4-19 Effect of mixture of FAS-40A and selected surfactants on flotation of $-355+250 \mu \mathrm{m}(-45+60 \mathrm{mesh})$ feed 83 
Fig. 4-20 Effect of mixture of FAS-40A and selected surfactants on flotation of $-250+150 \mu \mathrm{m}(-60+100$ mesh) feed 84

Fig. 4-21 Effect of mixture of FAS-40A and selected surfactants on flotation of $-150+75 \mu \mathrm{m}(-100+200$ mesh) feed 85

Fig. 4-22 Dolomite flotation recovery as a function of slime contents at different FAS-40A dosages 86

Fig. 4-23 Dolomite flotation recovery as a function of slime contents at different dosages of the mixture of FAS-40A and $10 \%$ DSS1 87

Fig. 4-24 Dolomite flotation recovery as a function of slime contents at different dosage of the mixture of FAS-40A and 10\% DP .88

Fig. 4-25 Dolomite flotation recovery as a function of slime contents at different dosages of the mixture of FAS-40A and $10 \% \mathrm{TW}$ 89

Fig. 4-26 Dolomite flotation recovery as a function of slime content at collector dosage of 50 ppm FAS-40A with $10 \%$ selected surfactant 90

Fig. 4-27 Dolomite flotation recovery as a function of slime content at collector dosage of 75 ppm FAS-40A with $10 \%$ selected surfactant 91

Fig. 4-28 $\quad \mathrm{MgO}$ and $\mathrm{P}_{2} \mathrm{O}_{5}$ grade in dolomite flotation float as a function of flotation $\mathrm{pH}$ 94

Fig. 4-29 $\mathrm{MgO}$ and $\mathrm{P}_{2} \mathrm{O}_{5}$ recovery in dolomite flotation float as a function of flotation $\mathrm{pH}$ 96

Fig. 4-30 $\mathrm{Ca}^{2+}$ and $\mathrm{Mg}^{2+}$ concentration in the solution of flotation slurry of natural xiv 
dolomitic phosphate as a function of $\mathrm{pH}$

Fig. 4-31 Effect of FAS-40A collector and DSS1 surfactant on $\mathrm{Ca}^{2+}$ and $\mathrm{Mg}^{2+}$ at

different $\mathrm{pH}$

Fig. 4-32 Effect of selected surfactants on the weight percentage of the float using

FAS-40A collector with and without surfactant 101

Fig. 4-33 Effect of selected surfactants on MgO grade in float using FAS-40A collector with and without surfactant 102

Fig. 4-34 Effect of selected surfactants on MgO recovery in float using FAS-40A collector with and without surfactant 103

Fig. 4-35 Effect of selected surfactants on $\mathrm{P}_{2} \mathrm{O}_{5}$ grade in sink using FAS-40A collector with and without surfactant 104

Fig. 4-36 Effect of selected surfactants on $\mathrm{P}_{2} \mathrm{O}_{5}$ loss in dolomite tailings using FAS-40A collector with and without surfactant .105

Fig. 4-37 Effect of selected surfactants on MgO grade in sink using FAS-40A collector with and without surfactant

Fig. 4-38 Effect of selected surfactants on acid insoluble in float using FAS-40A collector with and without surfactant

Fig. 4-39 Photos showing difference in froth product with and without DSS1 111

Fig. 4-40 pH effect on MgO grade and recovery in float using FAS-40A collector with and without DSS1 113

Fig. 4-41 pH effect on $\mathrm{P}_{2} \mathrm{O}_{5}$ grade and recovery in float using FAS-40A collector with 
Fig. 4-42 MgO grade and recovery in the dolomite flotation tailings as a function of collector dosage with and without surfactant DSS1

Fig. 4-43 $\mathrm{MgO}$ and $\mathrm{P}_{2} \mathrm{O}_{5}$ grade in the dolomite flotation tailings as a function of collector dosage with and without surfactant DSS1

Fig. 4-44 $\mathrm{MgO}$ and $\mathrm{P}_{2} \mathrm{O}_{5}$ recoveries in the dolomite flotation tailings as a function of collector dosage and separation selectivity index with and without DSS1

Fig. 4-45 Selectivity Index of dolomite flotation using different dolomite collectors. 120

Fig. 4-46 Comparison of the observed responses and predicted responses with reduced

model

Fig. 4-47 Interactive effect of $\mathrm{pH}$ and collector dosages with the selectivity index as separation responses

Fig. 4-48 Interactive effect of $\mathrm{pH}$ and air flow rate with the selectivity index as separation responses

Fig. 4-49 Interactive effect of air flow rate and collector dosages with the selectivity index as separation responses.

Fig. 4-50 Relationship between $\mathrm{P}_{2} \mathrm{O}_{5}$ grade and $\mathrm{P}_{2} \mathrm{O}_{5}$ recovery in the sink product of dolomite flotation

Fig. 4-51 Relationship between $\mathrm{P}_{2} \mathrm{O}_{5}$ and $\mathrm{MgO}$ grade in the sink product of dolomite flotation 139

Fig. 4-52 Relationship between $\mathrm{MgO}$ grade and $\mathrm{P}_{2} \mathrm{O}_{5}$ recovery in the sink product of xvi 
dolomite flotation

Fig. 4-53 Flotation flowsheet of dolomite flotation with modified packed column and silica flotation with mechanic cell...................................................................... 142 


\section{CHAPTER 1 INTRODUCTION}

\subsection{Background}

Phosphate rock is a vital, nonrenewable and non-substitutable mineral resource. The demand must be met through the mining, beneficiation and chemical processing of naturally derived materials. Although phosphorous has never been priced as high as gold and called precious, its availability may be much more essential to human existence than that of the precious elements. It is never overstated that "People can not live without phosphate". Major application of phosphate is to manufacture phosphate fertilizers which consumes about $90 \%$ of the phosphate produced. The remaining $10 \%$ is used by other industries, such as for manufacturing of detergents, water softeners, cleaners, insecticides, dental products, animal food, and soft drink we drink every day. World demand for fertilizers will continuously increase due to the increase of population. The International Fertilizer Industry Organization has predicted that worldwide demand for phosphate fertilizers will grow at an annual rate of $2.5 \%$ during the next 5 years.

Most of the phosphate rock produced is used for the production of phosphoric acid which is a precursor for many phosphate products. The phosphoric acid is produced by treating the phosphate rock with sulfuric acid.

\subsection{Phosphate Reserves}

The increasing demand for world food production calls for the long term growth in the world phosphate rock production. The world phosphate production and reserves given in Table 1-1 indicates that the United States is the leading supplier of processed phosphates in the world. 
Table 1-1 World Phosphate Production, Reserves, and Reserve Base (thousand metric tons) $^{\mathrm{a}}$

\begin{tabular}{|c|c|c|c|c|c|}
\hline \multirow{2}{*}{ Country } & \multicolumn{3}{|c|}{ Phosphate production } & \multirow{2}{*}{ Reserves } & \multirow{2}{*}{$\begin{array}{c}\text { Reserve } \\
\text { bases }\end{array}$} \\
\hline & 2003 & 2004 & $2005^{\mathrm{b}}$ & & \\
\hline United States & 35,000 & 35,800 & 38,300 & $1,200,000$ & $3,400,000$ \\
\hline Australia & 2,290 & 2,010 & 2,000 & 77,000 & $1,200,000$ \\
\hline Brazil & 5,600 & 5,400 & 6,400 & 260,000 & 370,000 \\
\hline Canada & 1,000 & 1,000 & 1,000 & 25,000 & 200,000 \\
\hline China & 24,500 & 25,500 & 26,000 & $6,600,000$ & $13,000,000$ \\
\hline Egypt & 2,140 & 2,220 & 2,230 & 100,000 & 760,000 \\
\hline India & 1,180 & 1,180 & 1,200 & 90,000 & 160,000 \\
\hline Israel & 3,210 & 2,950 & 3,200 & 180,000 & 800,000 \\
\hline Jordan & 6,760 & 6,220 & 7,000 & 900,000 & $1,700,000$ \\
\hline Morocco & 23,000 & 26,700 & 28,000 & $5,700,000$ & $21,000,000$ \\
\hline Russia & 11,000 & 11,000 & 11,000 & 200,000 & $1,000,000$ \\
\hline Senegal & 1,470 & 1,600 & 1,800 & 50,000 & 160,000 \\
\hline South Africa & 2,640 & 2,740 & 2,000 & $1,500,000$ & $2,500,000$ \\
\hline Syria & 2,430 & 2,880 & 3,000 & 100,000 & 800,000 \\
\hline Togo & 1,480 & 1,120 & 1,120 & 30,000 & 60,000 \\
\hline Tunisia & 7,890 & 8,050 & 8,000 & 100,000 & 600,000 \\
\hline Other countries & 5,000 & 4,820 & 4,900 & 800,000 & $2,000,000$ \\
\hline World total & 137,000 & 141,000 & 148,000 & $18,000,000$ & $50,000,000$ \\
\hline
\end{tabular}

\footnotetext{
a Source: U.S. Geological Survey, Mineral Commodity Summaries, January 2005.
}

b Estimated.

Florida is rich in phosphate resources. It has been more than 120 years since 
phosphate in central Florida was started mining in 1880. In recent years, its annual phosphate production accounts for one fourth of the total output of the world. It is estimated that the Florida phosphate reserve that could be economically processed with the available phosphate beneficiation technology could last only about 20 years at the current mining rate. With the depletion of the low dolomite, easy-to-process high-grade siliceous phosphate ore from the Bone Valley Formation deposits, the phosphate mining moves further south and southeast, and the phosphate matrix in those areas will be leaner in $\mathrm{P}_{2} \mathrm{O}_{5}$ grade and higher in dolomite. The phosphate deposits in the south extension may be divided into two zones: an upper zone and a lower zone. The upper zone is readily processable using the current beneficiation technology, but the lower zone is highly contaminated by dolomite. Geological and mineralogical data show that about $50 \%$ of the phosphate resources would be wasted if the lower zone is bypassed during the mining process, and about $13 \%$ of the phosphate resources would be lost if the dolomite pebble in the lower zone is discarded.

\subsection{Objectives of This Study}

Many studies have been carried out on Florida dolomitic phosphate ores and different processes have been developed since the 1970s. Those processes include International Mineral and Chemical Company (IMC) cationic process, Tennessee Valley Authority (TVA) diphosphonic acid process, University of Florida (UF) two stage conditioning process, University of Alabama (UA) no conditioning process, US Bureau of Mines (USBM) scrubbing and flotation process and so on. In 1995, Florida Institute of Phosphate Research conducted an in-house comprehensive evaluation on all those processes using the same dolomitic phosphate sample and the work was performed by the same researcher with the results summarized in Table 1-2. 
Table 1-2 Summary of Process Developed for Florida Dolomitic Phosphate

Beneficiation

\begin{tabular}{|c|c|c|c|c|}
\hline \multirow{2}{*}{ Process } & \multirow{2}{*}{$\begin{array}{c}\text { Feed Size } \\
\text { (Tyler mesh) }\end{array}$} & \multicolumn{3}{|c|}{ Concentrate, \% } \\
\cline { 3 - 5 } & & $\mathrm{P}_{2} \mathrm{O}_{5}$ & $\mathrm{MgO}$ & $\mathrm{P}_{2} \mathrm{O}_{5}$ recovery \\
\hline IMC & $-35+150$ & 31.66 & 0.84 & 58.4 \\
\hline USBM & $-28+150$ & 31.73 & 1.22 & 27.4 \\
\hline UF & $-35+150$ & 28.97 & 0.97 & 27.7 \\
\hline TVA & $-48+325$ & 30.73 & 1.51 & 66.0 \\
\hline UA & $-35+150$ & 26.20 & 1.19 & 87.1 \\
\hline
\end{tabular}

It can be clearly seen that the most promising process is IMC cationic flotation flowsheet which could produce a final phosphate concentrate containing $31.66 \% \mathrm{P}_{2} \mathrm{O}_{5}$ and $0.84 \% \mathrm{MgO}$ at $58.4 \% \mathrm{P}_{2} \mathrm{O}_{5}$ recovery. All other processes failed to generate an acceptable phosphate concentrate either because of low $\mathrm{P}_{2} \mathrm{O}_{5}$ grade or high $\mathrm{MgO}$ content. In the IMC process, an amine condensate (AZ-36A) was used with diesel oil as a collector to float silica first, followed by using tallow amine (Armac T) and diesel oil as a collector and Tergitol NP-10 as a frother for phosphate flotation. Because of the use of two types of amine collectors for silica and phosphate flotation respectively, it has been known as IMC cationic process. However, there are two disadvantages with the IMC cationic process. One is that two types of amine collectors were used for both silica flotation and phosphate flotation. Generally speaking, cationic collector is much more expensive than fatty acid collector. Another one is that, in the second cationic flotation stage, about $90 \%$ of the material was floated as concentrate, and $10 \%$ was kept in sink as 
tailings which might require high reagent consumption. Actually, IMC cationic process is a combination of silica flotation and phosphate flotation rather than dolomite flotation. In recent years, a new flotation process developed by China Lianyungang Design and Research Institute known as CLDRI fine particle flotation process had been developed for Florida dolomitic phosphate ores (Gu et al., 1998, Gu et al. 1999, El-Midany, 2005). In this process, a fatty acid type collector, PA-31, was used. This collector was made of local raw materials in China (Lu and Sun, 1999). In 2000, a pilot-scale demonstration of CLDRI fine particle flotation process was carried out in Jacobs Engineering's pilot pant facility on high dolomitic pebble samples in Florida (Gruber et al., 2001). The collector used for the pilot plant operation was imported from China.

The objectives of this study are: 1) to improve the separation of dolomite from phosphate using selected fatty acid collectors readily available domestically and using selected surfactants; 2) to conduct flotation tests with Hallimond cell, Denver mechanical cell and modified packed column; 3) to achieve the separation performance equivalent to or better than that by other dolomite collectors; 4) to confirm the effectiveness of the selected surfactant on dolomite flotation with two different dolomitic phosphate samples, and 5) to conduct fundamental study on frothability and froth stability for the explanation of the flotation results with the new reagents. 


\section{CHAPTER 2 LITERATURE REVIEW}

\subsection{Similarity in Properties of Carbonate and Phosphate Minerals}

Among the impurities in phosphate ores, carbonates such as dolomite and calcite are the most detrimental components that will cause considerable problems in downstream operation. Higher carbonate contents in phosphate concentrate will result in high sulfuric acid consumption and high viscosity in phosphoric acid production, which will dramatically increase the operation cost of the process. Separation of dolomite from phosphate has long been recognized as a difficult mission due to various reasons. In dolomitic phosphate ores, the carbonates are disseminated with phosphate minerals in extremely fine particles, which will require fine grinding to achieve satisfactory phosphate liberation from dolomite. The phosphate minerals exploited in industrial scale are called apatite with the chemical formula of $\mathrm{Ca}_{3}\left(\mathrm{PO}_{4}\right)_{2}$. During the formation of the phosphate ore, different varieties of apatite were formed due to partial substitution of phosphate ions $\mathrm{PO}_{4}{ }^{3-}$ by other component like $\mathrm{Cl}^{-}, \mathrm{OH}^{-}, \mathrm{CO}_{3}{ }^{2-}$, etc., corresponding to chlorapatite, hydrapatite, carbonated apatite and so on. It can be seen that both apatite $\left[\mathrm{Ca}_{3}\left(\mathrm{PO}_{4}\right)_{2}\right]$ and dolomite $\left[(\mathrm{Ca}, \mathrm{Mg}) \mathrm{CO}_{3}\right]$ or calcite $\left[\mathrm{CaCO}_{3}\right]$ are all oxide-type minerals with calcium as the cationic part. Both of them are slightly water-soluble. In the presence of one another in water system with surfactants and modifiers, the reaction will become exceedingly complex due to self-aggregation and precipitation of surfactants, dissolution 
of solids, hydrolysis/complexation/precipitation of different species and the interaction of modifiers with other species in the solution. These will complicate the separation because of the similarities of the adsorption and desorption behavior of the two types of minerals in the flotation process.

\subsection{Development of Carbonate Separation Processes}

Systematic research in carbonate phosphate ore beneficiation started in the early fifties (Miche, 1953; Borisov, 1956). Since then, research efforts in this area have been extensive. The techniques investigated or proposed may be divided into six groups: 1) direct flotation of phosphate with the addition of sodium silicate to depress the carbonate gangue; 2) reverse flotation of the carbonate gangue while depressing the phosphate; 3 ) rapid change of flotation parameters; 4) physical methods (gravity, attrition, heavy media); 5) calcinations; and 6) acid leaching. Although the first column flotation plant in the world was erected for processing phosphate in the 1980's, little progress has been made in application of flotation column in the phosphate industry since then, and almost no work has been done in applying flotation column to beneficiating dolomitic phosphate ores.

\subsubsection{Depression of Phosphate}

The United States Bureau of Mines (USBM) has developed three processes for high-dolomite phosphates. They are: 1) the removal of carbonates using fluosilicic acid 
for phosphate mineral depression and a tall oil-fatty acid as collector for carbonate mineral flotation; 2) the scrubbing-dolomite flotation process; and 3) the $\mathrm{SO}_{2}$ Process (Rule et al., 1970, 1974, 1982, 1985). For the fluosilicic acid process using the reagent dosage of $0.7 \mathrm{~kg} / \mathrm{t}$ of fatty acid, $0.45 \mathrm{~kg} / \mathrm{t}$ of $\mathrm{H}_{3} \mathrm{SiFO}_{4}$, a concentrate with $25.5 \% \mathrm{P}_{2} \mathrm{O}_{5}$ and $0.84 \% \mathrm{MgO}$ was obtained at the $\mathrm{P}_{2} \mathrm{O}_{5}$ recovery of $89.5 \%$ from a feed of $20.8 \% \mathrm{P}_{2} \mathrm{O}_{5}$ and $1.1 \% \mathrm{MgO}$. The concentrate grade was, however, not satisfactory.

The efficiency of phosphate depression by fluosilicic acid was also studied by Celerici et al. (1984). Carbonate flotation was carried out at $\mathrm{pH} 6.5$, with $500 \mathrm{~g} / \mathrm{t}$ of tall oil as collector and $300 \mathrm{~g} / \mathrm{t}$ of $\mathrm{H}_{2} \mathrm{SiF}_{6}$ as phosphate depressant. A reasonable grade of concentrate was obtained. However, the overall $\mathrm{P}_{2} \mathrm{O}_{5}$ recovery was less than $28 \%$.

A study by Atalay and coworkers (1985) indicated that fluosilicic acid was not as efficient as diphosphonic acid or phosphoric acid for depressing a Turkish phosphate ore. The fluosilicic acid process gave a concentrate assayed less than $26 \% \mathrm{P}_{2} \mathrm{O}_{5}$, at BPL recovery of below $57 \%$.

Ratobylskaya et al. (1975) found that orthophosphoric acid could increase the surficial solubility of apatite and render it unfit for fatty acid adsorption. Using $6 \mathrm{~kg} / \mathrm{t}$ phosphoric acid and $0.3 \mathrm{~kg} / \mathrm{t}$ fatty acid at $\mathrm{pH} 5$, these investigators were able to recover $75 \%$ of the $\mathrm{P}_{2} \mathrm{O}_{5}$ and eliminate most of the carbonate gangue. Carbonate flotation was followed by direct phosphate flotation after increasing the $\mathrm{pH}$ to $7.6-8.0$ using $1.5 \mathrm{~kg} / \mathrm{t}$ caustic soda.

Phosphoric acid was used as an apatite depressant by USBM in separating dolomite 
from a southern Florida ore (Llewellyn, 1982). However the results were not encouraging. The concentrate containing 27.5\% $\mathrm{P}_{2} \mathrm{O}_{5}, 1.9 \% \mathrm{MgO}$, and $6.3 \%$ insoluble was reported.

International Fertilizer Development Center (IFDC) (Lawendy, et al., 1993) compared the results of several flotation processes, including diphosphonic acid process, phosphoric acid process, fluosilic acid process, sodium triployphosphric acid process, aluminum sulfate and tartaric acid process, etc. It was found that the phosphoric acid depression process gave the best results. The grades of the concentrate were 32.2- 36.6\% $\mathrm{P}_{2} \mathrm{O}_{5}, 1.0 \% \mathrm{MgO}$ at $70-75 \%$ overall $\mathrm{P}_{2} \mathrm{O}_{5}$ recovery from run-of-mine rocks containing $16.7-25 \% \mathrm{P}_{2} \mathrm{O}_{5}$ and $4.0-11.6 \% \mathrm{MgO}$.

One of the most frequently mentioned Tennessee Valley Authority (TVA) processes is the diphosphonic acid depressing method (Hsieh and Lehr, 1985; Lehr and Hsieh, 1981). At reagent dosages of $2 \mathrm{~kg}$ of fatty acid, $0.4 \mathrm{~kg}$ of fuel oil, and $0.5 \mathrm{~kg}$ depressant per ton of feed, a concentrate with $0.7 \% \mathrm{MgO}$ was achieved.

Studies conducted by International Mineral \& Chemical-Agrico Company (IMCA) (Gruber, Raulerson, and Farias, 1987) indicated that complete depression of phosphate could be achieved by adjusting pulp $\mathrm{pH}$ by sulfuric acid to 5.5 in seawater and 3.0 in fresh water.

Calcite in a Moroccan phosphate ore was successfully depressed using a 2:1 mixture (by weight) of aluminum sulfate and tartaric acid (Smani, Cases, and Blazy, 1975; Houot and Polgaire, 1980). A concentrate with $32.1 \% \mathrm{P}_{2} \mathrm{O}_{5}$ and $0.43 \% \mathrm{MgO}$ was obtained from a feed containing $23.24 \% \mathrm{P}_{2} \mathrm{O}_{5}$ and $3.29 \% \mathrm{MgO}$. Reagent dosages were 1300-1500 g 
oleic acid, 200-250 g aluminum sulfate, 400-500 g Na-K-tartarate, 650-750 g alcohol, and 500-600 g soda per ton of feed.

Rao et al. $(1985,1979)$ conducted an extensive study on an Indian carbonaceous phosphate ore. Comparison tests on hydrofluosilicic acid, starch and dipotassium hydrogen phosphate showed that $\mathrm{K}_{2} \mathrm{HPO}_{4}$ was superior to the others in depressing phosphate in the test sample. One of the important findings of this study was that $\mathrm{K}_{3} \mathrm{PO}_{4}$ depressed apatite flotation completely at pH 5 to 8, while calcite flotation was depressed only under alkaline conditions. These results suggest that selective flotation is possible by controlling the $\mathrm{pH}$ range of the flotation process, but the final concentrate contained only $24 \% \mathrm{P}_{2} \mathrm{O}_{5}$

Studies by $\mathrm{Fu}$ and Somasundaran (Fu and Somasundaran, 1986; Xiao and Somasundaran, 1989) showed that calcite was depressed by alizarin red S (ARS) between $\mathrm{pH} 8$ and 10, while apatite depression occurred at pH below 6. Therefore, ARS could be used either as a carbonate depressant or apatite depressant by selecting the appropriate $\mathrm{pH}$ range of the flotation pulp. Some fundamental studies on ARS for phosphate beneficiation have also been conducted by Wu and Forsling (1993).

\subsubsection{Depression of Carbonate}

Sodium silicate is widely used as a carbonate depressant in beneficiating metallic minerals. The depression effect of sodium silicate on carbonatic gangues in phosphate rock is also investigated (Fuerstenau, 1968; Rao, 1988; Ananthapadmanabhan and 
Somasundaran, 1985). Some encouraging results were obtained in both batch and continuous pilot tests conducted by USBM (Davis, Llewellyn, and Smith, 1984).

Rao et al. (1989) studied the effects of major flotation parameters on phosphate grade and recovery using sodium silicate as a calcite depressant. Maximum flotation of apatite occurred at $\mathrm{pH} 8$, and phosphate recovery decreased at high $\mathrm{pH}$. Sodium silicate at a concentration below $0.0013 \mathrm{M}$ had no depressive effect on calcite. However, calcite depression was observed even in dilute silicate solution at $\mathrm{pH}$ values above 10. A concentrate with $25.6 \% \mathrm{P}_{2} \mathrm{O}_{5}$ was achieved at $80 \% \mathrm{P}_{2} \mathrm{O}_{5}$ recovery.

In an effort to determine if apatite could be concentrated by flotation from high dolomitic phosphate ores using conventional fatty acid-fuel oil flotation, Llewellyn et al. (1982) found that sodium silicate depression on dolomite was not significant enough to obtain a concentrate with less than $1 \% \mathrm{MgO}$ even with three stages of cleaning and the addition of $1.36 \mathrm{~kg} / \mathrm{ton}$ of sodium silicate. Numerous tests conducted by IMC in the past 20 years and a study by FIPR (Snow 1994) also indicated that sodium silicate is virtually powerless in depressing dolomite in the Florida dolomitic phosphate pebbles.

\subsubsection{Acid Leaching}

Carbonates in phosphate rock can be easily leached by any strong acid. Unfortunately, strong acids also attack the apatite while leaching carbonates. This is one of the major obstacles to utilizing acid leaching processes for removing carbonates, especially dolomite from phosphate ores. To avoid attacking phosphate, weak acids have been 
studied as leaching agents. However, these organic acids are usually too expensive to justify their utilization. Nonetheless, because of its low capital cost and effective removal of carbonates, acid leaching has been studied continually.

In the early seventies, USBM investigated several leaching agents for the removal of magnesium impurities from phosphate rock concentrates (Rule, et al., 1970). The MgO level was reduced to less than $0.1 \%$ with dilute sulfuric acid from a concentrate roasted at $500^{\circ} \mathrm{C}$. However, phosphate loss was substantial. Removal of $\mathrm{MgO}$ by ammonium sulfate leaching was achieved only from concentrates roasted at $900^{\circ} \mathrm{C}$. Phosphate loss was minimal when concentrates were leached with $\mathrm{SO}_{2}$ gas and reduction of $\mathrm{MgO}$ level to $0.3 \%$ was achieved with uncalcined phosphate rock.

Leaching of magnesium from phosphate using sulfuric acid has been actively pursued by the Russian investigators (Kromf, et al. 1979; Belyakov, et al., 1981). In one study, the quality of wet-process $\mathrm{H}_{3} \mathrm{PO}_{4}$ was greatly improved by sulfuric acid pretreatment. A concentrate containing $37.2 \% \mathrm{P}_{2} \mathrm{O}_{5}, 50.7 \% \mathrm{CaO}$ and $0.76 \% \mathrm{MgO}$ was obtained from a raw apatite assaying $37.8 \% \quad \mathrm{P}_{2} \mathrm{O}_{5}, \quad 53 \% \quad \mathrm{CaO}$ and $2.6 \% \mathrm{MgO}$ (Treushchenko, 1979; Valoven, 1979). Some intriguing concepts evolved from the study of the sulfuric acid leaching process (Laird and $\mathrm{Ng}, 1992$ ) are: a) expelling the carbon dioxide produced by leaching, b) accurate $\mathrm{pH}$ control by computer, and c) converting soluble magnesium into magnesium nitrate.

Weak organic acids such as acetic acid, citric acid and formic acid can also be used for leaching carbonates. Acetic acid seems to give some advantages. A pilot study by 
Abu-Elshah et al. (1991) found that a 6.7\% acetic acid solution could effectively remove more than $80 \% \mathrm{MgO}$ and obtain a concentrate of over $32 \% \mathrm{P}_{2} \mathrm{O}_{5}$ from a Jordan phosphate ore in a water to solid ratio of 4:1 slurry. Acetic acid was recovered from the acetate solution by the reaction of calcium acetate with sulfuric acid.

\subsubsection{Calcination}

Calcination is a rather mature and technically sound pyro-metallurgical unit operation, and it is the only industrially used technology for complete removal of carbonates from phosphate rock, particularly rock that is high in calcareous gangues. Africa and the Western U.S. have been using calcination for many years.

Recently calcination was studied and recommended in Saudi Arabia where the water supply is limited and energy is inexpensive. A Saudi phosphate ore containing 40-50\% carbonate and $16-25 \% \quad \mathrm{P}_{2} \mathrm{O}_{5}$ was treated by calcination at $850^{\circ} \mathrm{C}$ for about one hour, followed by quenching with $5 \% \mathrm{NH}_{4} \mathrm{NO}_{3}, 5 \% \mathrm{NH}_{4} \mathrm{Cl}$, or water. Under the best test conditions, a concentrate containing $38 \% \mathrm{P}_{2} \mathrm{O}_{5}$ was obtained (Al-Fariss, 1993).

Two low grade Indian carbonaceous ores were successfully upgraded using a continuous-flow calcination process (Good, 1976). Phosphate recoveries ranged from 63 to $84.6 \%$ with concentrate grades of 31.3 to $38.5 \%$. The roasting temperature was $900^{\circ} \mathrm{C}$.

\subsubsection{Physical Separation Methods}

Although spirals, shaking tables and some other physical techniques have been used 
for eliminating part of carbonate gangue from phosphates, none of them alone could achieve an acceptable concentrate from high dolomitic phosphate ores (Baumann and Snow, 1980). IMCA leads the phosphate industry in commercializing physical technology for separating dolomite from apatite (Lawver and Snow, 1982; Wiegel and Hwang 1984). Using the heavy media separation technique, IMCA is able to obtain a concentrate with a $\mathrm{MgO}$ content around $1.2 \%$ from feeds with average value of $3 \% \mathrm{MgO}$. This relatively high dolomite concentrate is then blended with high $\mathrm{P}_{2} \mathrm{O}_{5}$ concentrates to obtain a blended product of less than $1 \% \mathrm{MgO}$.

Scrubbing prior to either dolomite or phosphate flotation has been tested on two of the Florida dolomitic phosphate pebble samples with some degree of success (Davis, Llewellyn, and Smith, 1984). The friable dolomite crystals were eliminated by scrubbing the $-300+106 \mu \mathrm{m}(-35+150$ mesh) size fraction flotation feed. Discarding the primary, secondary, and scrubbing slimes removed $92 \%$ percent of the total $\mathrm{MgO}$ content from one of the samples. While investigating beneficiation methods for recovering phosphate minerals from two Southern Florida deposits with high magnesium content, Llewellyn et al. (1982) was able to remove $92.7 \%$ of the total $\mathrm{MgO}$ content from one sample taken from Manatee county, and $85.4 \%$ from another sample from Hardee county by simply discarding minus $100 \mu \mathrm{m}$ fines after intensive attrition. 


\subsubsection{Column Flotation}

The first all column flotation plant was installed in the 1980's for processing western aluminum-bearing phosphate ore at Pocatello, ID (Finch and Dobby, 1991; Polinsky et al., 1989). The test results indicated that $50 \%$ of $\mathrm{Al}_{2} \mathrm{O}_{3}$ was rejected and $70 \%$ of $\mathrm{P}_{2} \mathrm{O}_{5}$ was recovered from the phosphate ore containing 2.3-2.7\% $\mathrm{Al}_{2} \mathrm{O}_{3}$ and $27.5 \% \mathrm{P}_{2} \mathrm{O}_{5}$, applying fluosilicic acid as depressant and fatty acid as collector.

Some investigators have also conducted researches on applying flotation column for beneficiating siliceous phosphate ores. Hutwelker et al. (1994) used a $9.5 \mathrm{~cm}$ diameter by $2.26 \mathrm{~m}$ tall column to process $-850+75 \mu \mathrm{m}(-20+200 \mathrm{mesh})$ North Carolina phosphate ore at $45 \%$ solids and at throughputs of 19.1 and $31.7 \mathrm{t} / \mathrm{hr} / \mathrm{m}^{2}$. A phosphate concentrate containing 26 to $29 \% \mathrm{P}_{2} \mathrm{O}_{5}$ was produced at the $\mathrm{P}_{2} \mathrm{O}_{5}$ recovery of $95 \%$ from North Carolina phosphate feed.

El-Shall et al. (1996) applied a $14.6 \mathrm{~cm}$ diameter and $1.83 \mathrm{~m}$ height laboratory-size column for flotation of Florida siliceous phosphate ores of different size ranges. It was reported that this column was capable of obtaining a concentrate with up to $31 \% \mathrm{P}_{2} \mathrm{O}_{5}$ at $98 \%$ recovery from a feed of $19.7 \% \mathrm{P}_{2} \mathrm{O}_{5}$ and $39.8 \%$ acid insoluble.

Mahlangu et al. (1998) tried to recover phosphate from a 90-95\% minus $45 \mu \mathrm{m}$ phosphate slimes by applying a $5.08 \mathrm{~cm}$ inside diameter and $5.5 \mathrm{~m}$ height flotation column. The test results indicated that a concentrate containing 22.87-31.21\% $\mathrm{P}_{2} \mathrm{O}_{5}$ could 
be achieved at the $\mathrm{P}_{2} \mathrm{O}_{5}$ recovery of 52.6-74.5\% from an igneous phosphate ore containing 4.3\% $\mathrm{P}_{2} \mathrm{O}_{5}, 11.8 \% \mathrm{MgO}$ and $9.0 \% \mathrm{Al}_{2} \mathrm{O}_{3}$.

In Florida phosphate production, one third phosphate is bound to the phosphate slimes which is currently discarded into huge tailings ponds in central Florida. The phosphatic slime contains very high dolomite which is the most problematic ingredient in wet phosphoric acid process. Ityokumbul (1998) attempted to recover the phosphate value from this fine phosphatic slime using a contact flotation cell. Although great efforts were made on this subject, there was no selective separation obtained.

\subsubsection{Other Development}

In the IMCA cationic process (Snow, 1982; Lawver and Snow 1980), a silica-free concentrate (either from a conventional "double float" process or one from a simple standard silica flotation step) is conditioned with a cationic collector at low $\mathrm{pH}$, and then apatite is floated by rougher, cleaner and recleaner phosphate flotations.

University of Alabama (UA) has developed a process called non-conditioning flotation (Hanna and Anazia, 1990), which is based on the fact that fatty acids adsorb more rapidly on carbonate surfaces than on those of phosphate. Thus, in a slightly acid circuit, carbonates could be floated immediately upon the addition of the collector and frother. After the collection of the carbonate froth, the pulp was conditioned briefly and then floated without further addition of collector.

A two-stage conditioning process has been developed by University of Florida (UF) 
(Moudgil, et al., 1986). In this new process the mineral is conditioned first at an alkaline $\mathrm{pH}$ with a conventional fatty acid collector, then reconditioned in a second stage at acidic $\mathrm{pH}$ with the same collector solution before flotation. Separation of dolomite from apatite is achieved without adding any depressant or other modifying agent. Selective flotation

of dolomite by reconditioning at $\mathrm{pH} 4$ is attributed to the combined effect of higher oleate adsorption on dolomite and hydrolysis of adsorbed oleate molecules to oleic acid at lower $\mathrm{pH}$ values.

Houot and Polgaire (1980) developed a double reverse flotation scheme for high carbonate phosphate ores. In this process, a reverse cationic flotation is first conducted to eliminate silica. The sink of silica flotation is then subjected to an anionic flotation to reject the carbonate. The study found that particle size had a significant effect on silica flotation and concluded that reverse flotation was an alternative solution for the beneficiation of sized ores of less than about 0.425-0.5 mm (32-35) mesh.

The effect of $\mathrm{pH}$ and collector type on the flotation selectivity of a Moroccan sedimentary ore was studied in detail by Smani, et al. (1975). The study found that whichever collector was used, calcite floated first and the phosphate minerals were depressed at specific $\mathrm{pH}$ ranges.

\subsection{Reagents for Carbonate Flotation}

In dolomitic phosphate ores, the proportion of dolomite content is usually smaller than that of phosphate minerals. There are three principle minerals in phosphate ores, 
apatite, dolomite and silica with the hardness of 5, 3.5 and 7 respectively. During crushing and grinding for liberating impurities from phosphate minerals, dolomite minerals are more easily ground to finer size than other minerals because of its lowest hardness. Generally speaking, fine particles should be floated more readily than large particles. Therefore, in most cases, reverse flotation of dolomite is considered as the first choice. In order to effectively separate dolomite from phosphate using reverse flotation, the reagents are most important.

\subsubsection{Fatty Acids and Their Salts}

In laboratory study, some pure fatty acids, such as oleic acid, can be used as collector to evaluate the floatability of minerals. It is rare to use pure fatty acids in industry. The majority of the fatty acids used in flotation are of vegetable origin as opposed to animal origin. Such fatty acids are known as tall oil fatty acids in industry. Usually the compositions of such fatty acids are quite complex. The vegetable-based fatty acids are basically composed of oleic acid $\left(\mathrm{CH}_{3}\left(\mathrm{CH}_{2}\right)_{7} \mathrm{CH}=\mathrm{CH}\left(\mathrm{CH}_{2}\right)_{7} \mathrm{COOH}\right)$, linoleic acid $\left(\mathrm{CH}_{3}\left(\mathrm{CH}_{2}\right)_{4} \mathrm{CH}=\mathrm{CHCH} \mathrm{CH}_{2} \mathrm{CH}=\mathrm{CH}\left(\mathrm{CH}_{2}\right)_{7} \mathrm{COOH}\right)$, and linolenic acid $\left(\mathrm{CH}_{3} \mathrm{CH}_{2} \mathrm{CH}=\mathrm{CHCH}_{2}\right.$ $\left.\mathrm{CH}=\mathrm{CHCH}_{2} \mathrm{CH}=\mathrm{CH}\left(\mathrm{CH}_{2}\right)_{7} \mathrm{COOH}\right)$ representing the unsaturated fatty acids. The saturated fatty acids are represented by palmitic acid $\left(\mathrm{CH}_{3}\left(\mathrm{CH}_{2}\right)_{14} \mathrm{COOH}\right)$ and stearic acid $\left(\mathrm{CH}_{3}\left(\mathrm{CH}_{2}\right)_{16} \mathrm{COOH}\right)$.

Smani (1975) applied oleic acid as collector and pine oil as frother to float carbonate minerals using the mixture of $\mathrm{Al}_{2}\left(\mathrm{SO}_{4}\right)_{3}$ and $\mathrm{Na}$, $\mathrm{K}$-tartrate at a weight ratio of $1: 2$ as 
phosphate depressant. It indicated that conditioning of the ore with $\mathrm{Al}_{2}\left(\mathrm{SO}_{4}\right)_{3}$ and $\mathrm{Na}$, K-tartrate caused the formation of a strongly electronegative film on the phosphate surfaces that might hinder the adsorption of anionic collectors and thus caused phosphate depression.

In the United States Bureau of Mines (USBM) process, phosphate minerals are depressed by hydrofluosilicic acid $\left(\mathrm{H}_{2} \mathrm{SiF}_{6}\right)$ while carbonate minerals are floated by using fatty acid emulsions. In this process, distilled tall oil is used as a collector at pH 6 (Rule, 1970).

In Tennessee Valley Authority (TVA) diphosphonic acid process (Lehr and Hsieh, 1981), phosphate minerals are depressed by ethylidene hydroxydiphosphonic acid and carbonate minerals are floated by using fatty acid collectors at $\mathrm{pH}$ 6.0-6.5.

In the phosphoric acid depression process reported by Houot and Polgarie (1980), phosphoric acid is used to depress phosphate minerals in acidic condition of $\mathrm{pH}$ 5.0-5.5 while carbonate minerals are floated with fatty acid collectors. It is claimed that phosphate ions are specifically adsorbed on the phosphate surface which causes formation of an electronegative film on the phosphate particles. Such film hinders the adsorption of anionic collectors which results in the depression of phosphate particles.

In sulfuric acid depression processes developed by $\mathrm{Wu}$ and Yang (1983), sulfuric acid is used to depress phosphate minerals, and carbonate minerals are floated with a fatty acid collector in acidic slurry of $\mathrm{pH}$ 5.0-5.5. The fatty acid used in this study is originally called oxidized paraffin soap. Due to the shortage of raw material for 
manufacturing oxidized paraffin soap, a new type of fatty acid collector, PA-31 was developed for reverse flotation of carbonate minerals (Lu and Sun, 1999). Plant operation data indicated that PA-31 could improve the selectivity of carbonate flotation and decrease the viscosity of the froth product. PA-31 is the fatty acid soap derived from cottonseed oil mixed with certain amount of non-ionic surfactant. They mentioned that surfactant addition promotes physical adsorption of reagent mixture onto carbonate mineral surfaces in acidic media while reducing its adsorption onto phosphate surface. PA-31 was considered as one of the most effective collectors for reverse flotation of carbonate minerals, particularly dolomite. This reagent was also used as carbonate flotation collector for processing dolomitic phosphate resources in Florida $(\mathrm{Gu}$ and Hwang, 1999, Grubber and Zheng, 2002).

\subsubsection{Sulfonated Fatty Acids}

Sulfonate-type flotation reagents were originally developed as relatively inexpensive anionic collectors to float iron-bearing minerals in low grade iron ores, and to remove iron and other minerals contaminants by flotation in the processing of glass sands, feldspar and other ceramic raw materials. Further development has resulted in additional reagents with a broadened application to the selective flotation of a variety of nonsulfide and nonmetallic minerals.

The IMC anionic process developed by Snow (1982) uses sodium tripolyphosphate as depressant to depress phosphate particles and sulfonated fatty acids to float carbonates. 
The sulfonated fatty acids have some advantages over normal fatty acids. Sulfonated fatty acids can selectively attach to alkaline earth metal carbonates in phosphate-containing ores and float away carbonate impurities. This reagent is highly resistant to the problems caused by widely fluctuating $\mathrm{pH}$ because the sulfonated fatty acid or its salts have strong and quite stable C-S linkage. The disadvantage is that it produces excessive foam. It is difficult to solve this problem when the laboratory scale test results are scaled to larger scales. It is reported (Lawendy and MeClellan, 1993) that the modification of IMC anionic process was made by mixing the sulfonated fatty acid with other reagents to control the foaming. They use this modified IMC anionic process to treat dolomitic phosphate ores from Jhamarkotra of India, Kaiyang of China, Safaga of Egypt, Nahal of Israel, Lagarban of Pakistan, and so on, and satisfactory results have been achieved. All the phosphate samples were ground to $300 \mu \mathrm{m}$ (48 mesh) and deslimed at $38 \mu \mathrm{m}$ (400 mesh).

\subsubsection{Phosphoric Esters}

Ammar Henchiri (1993) conducted carbonate flotation on Tunisian phosphate ore by using phosphoric ester as collector. In his study, the carbonate phosphate ore was crushed, ground and deslimed to make the flotation feed size of 32-106 $\mu \mathrm{m}$. The feed was conditioned with starch as depressant and phosphoric ester as collector for carbonate flotation. The underflow of carbonate flotation was subjected to phosphate flotation using fatty acid as collector at alkaline $\mathrm{pH}$ to reject silica. A concentrate containing over $30 \%$ 
$\mathrm{P}_{2} \mathrm{O}_{5}$ is obtained at the $\mathrm{P}_{2} \mathrm{O}_{5}$ recovery from the feed ore of $15 \% \mathrm{P}_{2} \mathrm{O}_{5}, 38.4 \% \mathrm{CaO}, 2.35 \%$ $\mathrm{MgO}$ and $18.5 \% \mathrm{SiO}_{2}$. He particularly mentioned that low initial concentration of phosphoric ester strongly improved the selectivity and froth quality, and thus stepwise addition of phosphoric ester was beneficial to the separation.

Baudet and Save (1999) conducted extensive evaluation on using ethoxylated phosphoric ester surfactants as collectors for flotation of carbonates from sedimentary phosphate ores at acidic $\mathrm{pH}$ condition from 4.5 to 6.5 with sulfuric acid or sodium fluorosilicate as phosphate depressant. They found that only fine carbonate particles in the range of 20 to 160 or 40 to $200 \mu \mathrm{m}$ were effectively removed by using phosphoric ester collector. This could be attributed to the high HLB values of collectors with a higher number of ethylene oxide units.

\subsubsection{Amphoteric Collector}

Most surfactants used as flotation collectors have a hydrophilic radical consisting of an aliphatic chain and a hydrophilic polar head. The polar head will determine the anionic or cationic character of the collectors. Some surfactants have the characteristics of being amphoteric. Characteristics of such surfactants will depend on $\mathrm{pH}$. They can behave either as cationic at acidic $\mathrm{pH}$ or as anionic at basic $\mathrm{pH}$. When such surfactants are used as collectors, the ionic property can be changed by controlling the $\mathrm{pH}$. Those products include alkyl amino propionic acid, alkyl propylene diamino propionic acid, alkyl propylene triamino propionic acid, alkyl propylene diamino dipropionic acid, etc. All 
these products are under the trade name "Calaflot".

Separation of phosphate from dolomite was reported by using such an amphoteric collector for processing igneous phosphate ores (Houot at al., 1985). The dolomitic phosphate ore was ground to liberation size first. The slurry was conditioned with Calaflot and fuel oil. Carbonate flotation was performed at natural $\mathrm{pH}$. The underflow of carbonate flotation was conditioned with $\mathrm{H}_{2} \mathrm{SO}_{4}$, Calaflot and fuel oil to float silica. A flotation concentrate containing $0.2-0.48 \% \mathrm{MgO}$ and $31.5 \% \mathrm{P}_{2} \mathrm{O}_{5}$ was obtained from the feed containing 1.29-1.58\% $\mathrm{MgO}$ and $27 \% \mathrm{P}_{2} \mathrm{O}_{5}$. Using this amphoteric collector, too wide range, from 10.67 to $89.67 \%$, of total $\mathrm{MgO}$ could be rejected.

At Siilingarvi phosphate mine in Finland, a substituted $\mathrm{N}$ sarcosine, an amphoteric reagent, was used as phosphate collector (Houot, 1982). The phosphate ore contained $10 \%$ apatite, $22 \%$ calcite and dolomite, $65 \%$ phlogopite and $3 \%$ amphibole and other silicates. The ore was ground to $38.5 \%$ passing $0.75 \mathrm{~mm}$ (200 mesh) for liberation. Phosphate flotation was conducted at $\mathrm{pH} 10.8$ with this amphoteric collector. After one roughing and five cleanings, phosphate concentrate containing $33.7 \% \mathrm{P}_{2} \mathrm{O}_{5}, 1.9 \% \mathrm{MgO}$ was achieved at the recovery of $85.8 \%$. The underflow of phosphate flotation was subject to calcite flotation with tall oil as collector to recover calcite.

Shao et al. (1999) reported that a new amphoteric surfactant, dodecy-Ncarboxyethyl-N-hydroxyethyl-imidazoline, was a good collector for the separation of dolomite and phosphate by flotation. In their study, dolomite showed good floatability at pH 3.5 and pH between 8 and 10. Such tendency was further enhanced when the flotation 
was carried out in the supernatant of francolite. The flotation results indicated that this new amphoteric collector had much better selectivity for dolomite flotation than fatty acids. It was claimed this collector was not sensitive to temperature or to dissolved ions in the flotation system. Actually they used this amphoteric reagent as a dolomite flotation collector. At pH 10 and collector dosage of $400 \mathrm{~g} / \mathrm{t}$, a phosphate concentrate containing $0.8 \% \mathrm{MgO}$ and $31.2 \% \mathrm{P}_{2} \mathrm{O}_{5}$ was obtained at the $\mathrm{P}_{2} \mathrm{O}_{5}$ recovery of $82 \%$ from the feed ore containing $13.9 \% \mathrm{MgO}$ and $23.5 \% \mathrm{P}_{2} \mathrm{O}_{5}$ (Abdel Khalek, 2001). It is interesting that dolomite flotation was performed under alkaline $\mathrm{pH}$ condition, about $\mathrm{pH} 10$. This is different from most dolomite flotation practices which are performed in acidic $\mathrm{pH}$ media.

\subsubsection{Others}

As early as in 1975, Seth and colleagues used disodium dodecyl phosphate as as calcite collector in processing calcite-apatite mineral system. They found that calcite was more readily floatable than the phosphate mineral. In their study, sodium carbonate or sodium bicarbonate were used to depress phosphate, and calcite was floated with disodium dodecyl phosphate as collector. The results indicated that about $53.7 \%$ of calcite could be floated at sodium carbonate dosage of $50 \mathrm{~g} / \mathrm{l}$ in $5 \times 10^{-4}$ mole/l disodium dodecyl phosphate solution.

Zheng et al. (2002) tried to remove dolomite from phosphate ore with a conventional flotation column and a three product column. In their study, various collectors were evaluated, including long chain alkyl sulfonates, tall oil plus fuel oil, disodium salt of 
1-hydroxyoctylidene 1, 1-diphosphonic acid. Glycol ether was used as a frother. $\mathrm{NaOH}$, $\mathrm{H}_{2} \mathrm{SO}_{4}, \mathrm{Na}_{2} \mathrm{CO}_{3}, \mathrm{Na}_{2} \mathrm{SiO}_{3}$, sodium carboxy-methylcellulose, and sodium citrate were used as $\mathrm{pH}$ modifier and/or depressants. A two-stage flotation scheme was proposed using column flotation to reject dolomite as the first stage, and mechanical cell flotation to recover phosphate as the second stage. Their experiment results indicated that dodecylbenzene sulfonate (Bio-Soft-D40) could give best performance in terms of both price and separation. A rough phosphate concentrate containing $19.6 \% \mathrm{P}_{2} \mathrm{O}_{5}$ and $0.85 \%$ $\mathrm{MgO}$ was obtained from the feed with $14.6 \% \mathrm{P}_{2} \mathrm{O}_{5}$ and $3.6 \% \mathrm{MgO}$ at the recovery of $81.5 \%$. The size of the flotation feed was minus $106 \mu \mathrm{m}$ plus $38 \mu \mathrm{m}(-150+400 \mathrm{mesh})$.

\subsection{Flotation with Surfactant Mixtures as Collectors}

With the increasing demand on raw materials, the mineral industry increasingly depends on the use of finely intergrown mineral resources. Such mineral resources usually contain a low content of valuable minerals, and both valuable minerals and gangue minerals have similar surface properties. In most cases, those minerals are enriched by flotation process. In standard flotation practice, anionic or cationic surfactants are used as collectors. Those collectors become anionic or cationic when

dissolved in water. Those ionized collectors are specifically adsorbed via electrostatic interaction of polar groups with the mineral surfaces and make mineral particles hydrophobic in different ways. Generally speaking, nonionic surfactants are less suitable for selective adsorption to make desired mineral particles hydrophobic because they have 
no ionic group. In order to increase the recovery of valuable minerals and improve the selectivity of separating valuable minerals from gangue minerals, the application of surfactant mixtures as collectors has been the research focus for a long time. The surfactants used to enhance mineral flotation include nonionic, anionic and cationic ones.

There are many examples in which nonionic surfactants are used to enhance the flotation process by increasing the mineral recovery, improving the separation selectivity or reducing the overall reagent consumptions. In Florida phosphate industry, the phosphate is recovered by conventional "Crago" double flotation process developed in 1930s. The "Crago" process consists of anionic rougher flotation with fatty acid type collector to recover phosphate first and cationic silica flotation with fatty acid amine as collector to float silica. In both of those flotation steps, nonionic surfactants are used. In anionic flotation of phosphate, fuel oil is used with fatty acid as phosphate collector. In amine flotation circuit, kerosene is used as the flotation aid. Both fuel oil and kerosene are nonionic surfactants which are used to improve the flotation performances.

Sis (2001) did extensive research work in an attempt to use nonionic surfactants to enhance flotation recovery of phosphate ores. In his study, he found that nonionic surfactants did not exhibit any collector-like action in the absence of oleate collector, but they could increase flotation recovery when some nonionic surfactants such as lower EO group nonylpheols were used with oleate collector. The recovery improvement was in the decreasing order of NP-4>NP-6>NP-7>NP-9>NP-15. Through his research work, he concluded that the roles of nonionic surfactants in flotation when used together with an 
ionic collector included (i) protecting the ionic collector from precipitation as insoluble surfactant salt; (ii) improving froth characteristics by reducing the surface tension at air/liquid interface; (iii) producing smaller bubbles by improving emulsification of fuel oil and (iv) improving adsorption of collector at the surface of mineral particles.

In some phosphate flotation plants, the flotation slurry was heated up to 40 to $45^{\circ} \mathrm{C}$ to achieve better solubility of fatty acid type collector in order to improve the phosphate flotation recovery. Lu and Sun (1999) reported that the flotation recovery of apatite could be increased by about $30 \%$ at $10^{\circ} \mathrm{C}$ by adding selected surfactant to collector in an amount less than $10 \%$ of collector dosage. The surfactants used in their study were sodium dodecylbenzene sulfonate and Tween- 80 . They reported that the addition of those reagents to the aqueous solution of oleic acid could reduce its surface tension and promote dispersion of oleic acid in flotation slurry. Further study with a proton nuclear magnetic resonance method confirmed that the application of surfactant in flotation could improve pre-micelling, emulsifying and dispersing of fatty acid collector in aqueous solution.

Since 1970's, extensive research has been conducted to develop technologies for separating dolomite from phosphate in order to make use of the phosphate resources associated with carbonate impurities. Most of those processes developed are dolomite flotation. However, there is not much information available on using surfactants to enhance the separation performances in dolomite flotation. Among the processes developed, CLDRI fine particle dolomite flotation technology is considered the most 
promising process ( $\mathrm{Gu}$ at al, 1999, Gruber et al. 2001, El-Midany et al. 2005). The process succeeded in lab and pilot plant scales. In CLDRI process, a special dolomite collector, PA-31, was used. It is a fatty acid type collector made from residues of cotton seed oil mixed with surfactant, diethyl phthalate. It is reported that the addition of diethyl phthalate could improve the separation performance by reducing the viscosity of flotation slurry and changing the characteristics of the froth. (Lu and Sun, 1998).

\subsection{Mechanisms of Dolomite Flotation in Acidic Media}

\subsection{1 pH Effect on Dolomite Flotation}

In the 1980s, Xiao and colleagues (1987) investigated the flotation behavior of dolomite and francolite at different oleate concentrations and different $\mathrm{pH}$. In their study, pure dolomite and francolite samples were used. Potassium oleate was selected as collector, $\mathrm{KOH}$ and $\mathrm{HNO}_{3}$ as $\mathrm{pH}$ modifiers. The Hallimond cell flotation results indicated that the floatability of both dolomite and francolite was quite similar and was very sensitive to the collector concentration. The flotation recovery of both pure dolomite and francolite as a function of $\mathrm{pH}$ at potassium oleate concentration of $1.7 \times 10^{-4} \mathrm{M}$ is plotted in Fig. 2-1. The figure shows that selective flotation of francolite is possible above $\mathrm{pH} 9.0$ and dolomite below $\mathrm{pH}$ 5.0. In their further experiments with binary mixture of dolomite and francolite as feed using same collector, they found that the selective separation could not be achieved at all at $\mathrm{pH}$ range from 4 to 11 . It was explained that the loss of selectivity of separation of dolomite from francolite could be attributed to the alteration 
of the surface properties of both minerals by the dissolved mineral species.

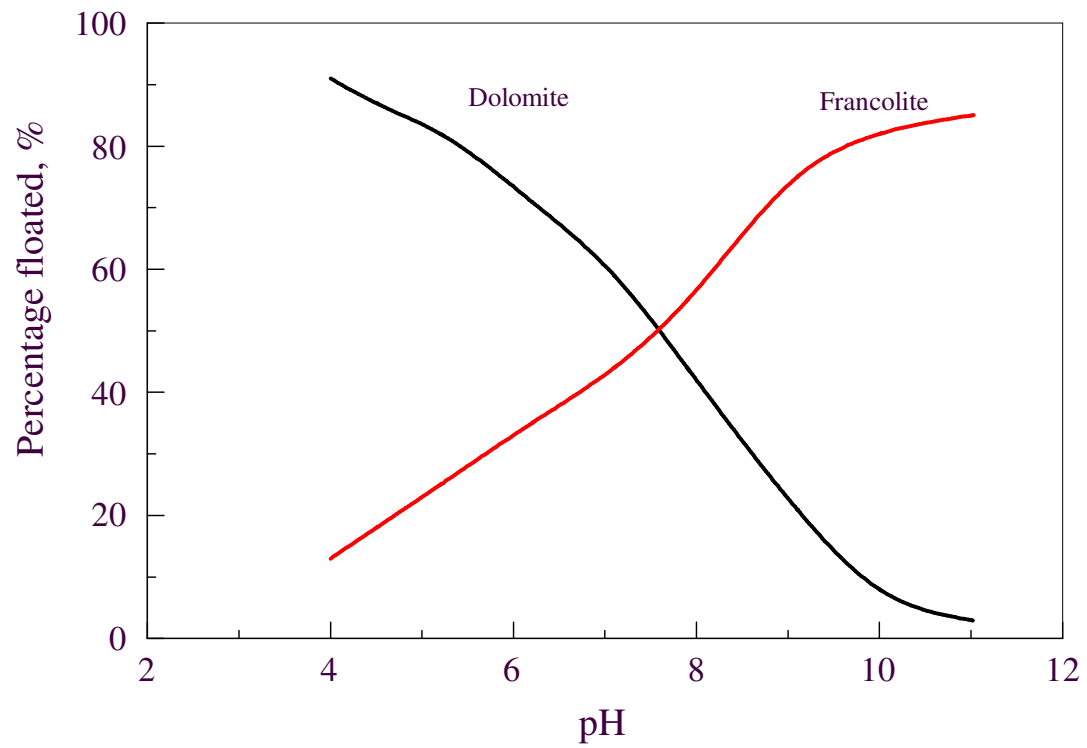

Fig. 2-1 Flotation of francolite and dolomite as a function of $\mathrm{pH}$ by Xiao et al. (1987)

\subsubsection{Mechanisms of Dolomite Flotation}

Many investigators have studied the carbonate-phosphate separation using fatty acid type collector to float carbonates in acidic media in the $\mathrm{pH}$ range of 4.5 to 6. (Smani, et al. 1975, El-Shall et al., 2004, Anazia and Hanna, 1988, Moudgil and Ince, 1991, Abramov et al., 1993, Elgillani and Abouzeid, 1993, El-Shall, et al., 1996, Prasad et al., 2000, Gu et al. 1999, Peng and Gu, 2005) Although extensive investigations have been conducted in this area, the mechanisms of dolomite flotation in acidic $\mathrm{pH}$ are not very well understood.

Smani et al. (1975) summarized the electrophoretic studies on phosphate and associated calcareous gangue minerals together with the flotation results of selective separation of phosphate and calcite. Their study indicated that when sodium oleate was 
used as collector, phosphate particles were floated above $\mathrm{pH}$ 6.0, and were sharply depressed between about $\mathrm{pH} 5.5$ and 6.0 and the flotation recovery increased at $\mathrm{pH} 4$. They explained that the flotation of phosphate above $\mathrm{pH} 6$ was due to the adsorption of oleate ions on the surface sites of phosphate particles. The depression of phosphate particles between pH 5.5 and 6.5 was due to the non-adsorption of collector, whatever the concentration of the collector might be. The flotation at $\mathrm{pH} 4$ was suggested to be due to adsorption of neutral collector molecules in the vicinity of the isoelectric point (IEP).

Mitzmager and co-workers (1966) investigated the effect of soluble alkali phosphate salts on oleate flotation of calcite from phosphate slimes and found that soluble alkali phosphate salts had selective depression action on phosphate minerals. They concluded that the mechanisms of phosphate and activation of calcite by soluble alkali phosphate salts were due to two effects. First, the depression of phosphate particles was caused by adsorption of molecular dicalcium phosphate $\left(\mathrm{CaHPO}_{4}\right)$ on phosphate surfaces, which probably replaced the adsorbed gypsum on the surfaces. Secondly, the mild attack of acid on calcite particles resulted in the evolution of tiny $\mathrm{CO}_{2}$ bubbles on calcite surface which is beneficial to calcite flotation.

Johnston and Leja (1978) conducted further research for understanding the complex nature of phosphate-carbonate flotation systems. Infrared spectroscopy and zeta potential measurements were used to explain the adsorption mechanisms. Some conclusions were drawn in their study. Firstly, flotation of phosphate was prevented by the depression action of soluble phosphate ions in acidic solutions and dolomite floats readily in 
presence of such ions. Secondly, if gypsum was present in the flotation feed, excessive phosphate ions were needed for the depression of apatite because of a fast metathesis reaction between gypsum and orthophosphate ions. It was also concluded that the depression action of phosphate ions on apatite was due to the formation of a more strongly hydrogen-bonded phosphate-water layer around apatite particles than around dolomite particles.

Elgillani and Abouzeid (1993) conducted a detailed thermodynamic analysis of the phosphate-carbonate-water system. The analysis showed that it was possible to float carbonates from phosphates in acidic media using an oleate collector in the presence of phosphate and calcium precipitating and complexing ions. Theoretical analysis and experimental results suggested that $\mathrm{CaHPO}_{4}$ was most probably the species responsible for apatite depression during dolomite flotation in acidic solution. They also pointed out that in order to promote the formation of $\mathrm{CaHPO}_{4}$ on phosphate minerals, free $\mathrm{Ca}^{++}$ions should be minimized or controlled by addition of sulfuric acid, chelating agent such as oxalic acid or a soluble phosphate salt to enhance phosphate depression.

Several investigators have reported the role of $\mathrm{CO}_{2}$ generation in acidic media from carbonate minerals. Johnston and Leja (1978) stated that evolution of $\mathrm{CO}_{2}$ from dolomite or calcite in acidic solutions disturbed the hydrogen bonding around apatite particles which allowed better adsorption of collector on dolomite or calcite particles and resulted in carbonate flotation while phosphate was depressed. Moudgil and Chanchani (1985) studied the dolomite flotation from Florida phosphate ore and described that dolomite 
would react with acid to form $\mathrm{CO}_{2}$ gas on its surface, which could facilitate the attachment of dolomite particles to air bubbles and thus improve the separation of dolomite from phosphate. However, they mentioned that it should result in higher dolomite flotation in low $\mathrm{pH}$ due to the formation of a great amount of $\mathrm{CO}_{2}$ gas, but they did not observe such high dolomite recovery below $\mathrm{pH}$ 4. Therefore, they believed that such phenomenon suggested that $\mathrm{CO}_{2}$ gas evolution did not play a primary role in the dolomite flotation in acidic media.

The fact that the formation of $\mathrm{CO}_{2}$ gas could be helpful for the flotation of dolomite mineral using fatty acid collector in acidic media can be further illustrated through reactive flotation process reported by El-Midany and co-workers (2005). In this reactive flotation process, dolomitic phosphate particles were first coated with some surfactant, then placed into dilute acid solution. After certain time period, dolomite particles could be floated without aeration for generating bubbles. They found out that the best surfactant was fully hydrolyzed polyvinyl alcohol (PVA) which was physically adsorbed on dolomite particles to reduce water surface tension and thus increasing contact angle of air bubbles on dolomite particles which leads to lower work of adhesion on dolomite surface. 


\section{CHAPTER 3 MATERIALS AND METHODOLOGY}

\subsection{Materials}

\subsubsection{Phosphate Ore Samples and Compositions}

Two separate dolomitic phosphate pebble (DPP) samples with different dolomite contents were collected from central Florida by IMC-Agrico Phosphate, Lakeland, Pork County, Florida, through Florida Institute of Phosphate Research (FIPR). The phosphate matrix is mined by high capacity dragline. The matrix mined is made into slurry using high pressure water-jet and then pumped to the phosphate beneficiation plant for washing operation using spiral classifier. After washing, the matrix was split by screens and cyclones into three streams, usually $+1 \mathrm{~mm},-1+0.1 \mathrm{~mm}$ and $-0.1 \mathrm{~mm}$ size fractions. The minus $106 \mu \mathrm{m}$ (150 mesh) fines as phosphatic slimes, which are discarded into tailings ponds due to the high impurities and low $\mathrm{P}_{2} \mathrm{O}_{5}$ content. The size fraction of $-1 \mathrm{~mm}+106$ $\mu \mathrm{m}$ is fed to conventional two stage "Crago" flotation process to recover phosphate concentrate by rejecting silica. The plus $1 \mathrm{~mm}$ coarse size fraction is known as phosphate pebble. This fraction is usually mixed with flotation concentrate to form a composite product for downstream production, if its $\mathrm{MgO}$ content is lower than a certain limit, such as $1.0 \sim 1.5 \%$. If the $\mathrm{MgO}$ content is higher than the limit, it is considered as dolomitic phosphate pebble (DPP) and will be discarded as waste. In Florida, there is a three one third principle, namely one third of the phosphate mineral is bound with slimes, one third 
is recovered with the "Crago" flotation process and another one third is contained in dolomitic phosphate pebble.

Among two dolomitic phosphate pebble samples collected for this study, one has high dolomite content (high $\mathrm{MgO}$ ) identified as sample $\mathrm{H}$, and another has low dolomite content indentified as sample L. Chemical analysis of the DPP sample Hs given in Table 3-1. It can be seen that the dolomitic phosphate pebble sample $\mathrm{H}$ contains $23.7 \% \mathrm{P}_{2} \mathrm{O}_{5}$, $3.34 \% \mathrm{MgO}$ and $12.46 \%$ acid insoluble, and sample $\mathrm{L}$ contains $26.14 \% \mathrm{P}_{2} \mathrm{O}_{5}, 1.5 \% \mathrm{MgO}$ and $8.8 \%$ acid insoluble. Both dolomite and silica should be rejected in order to produce a phosphate concentrate with over $30 \% \mathrm{P}_{2} \mathrm{O}_{5}$ and less than $1 \% \mathrm{MgO}$.

Table 3-1 Chemical analysis of dolomitic phosphate pebble samples

\begin{tabular}{|c|c|c|c|c|c|c|c|}
\hline \multicolumn{2}{|c|}{ Component } & $\mathrm{P}_{2} \mathrm{O}_{5}$ & $\mathrm{MgO}$ & Insol & $\mathrm{Fe}_{2} \mathrm{O}_{3}$ & $\mathrm{Al}_{2} \mathrm{O}_{3}$ & $\mathrm{CaO}$ \\
\hline \multirow{2}{*}{$\%$} & Sample H & 23.70 & 3.34 & 12.46 & 0.96 & 0.83 & 38.53 \\
\cline { 2 - 8 } & Sample L & 26.14 & 1.54 & 8.83 & 0.81 & 1.378 & 43.02 \\
\hline
\end{tabular}

The size distribution of the dolomitic phosphate pebble samples and chemical analysis of each size fraction for samples $\mathrm{H}$ and $\mathrm{L}$ are presented in Table A-1 and A-2, respectively, in Appendix A.

The analysis results show that coarse fraction and fine fraction of both samples A and B contain higher $\mathrm{MgO}$ content. For example, the $\mathrm{MgO}$ grade in plus $6.3 \mathrm{~mm}$ particle size in sample $\mathrm{L}$ is up to $7.57 \%$, much higher than that of feed which is only $1.67 \%$. The weight percentage of this fraction is $5.45 \%$, but it bounds about $25 \%$ of total $\mathrm{MgO}$ in the 
sample. Sample $\mathrm{H}$ contains much higher $\mathrm{MgO}$ content, up to $3.35 \%$, compared with sample $\mathrm{L} . \mathrm{MgO}$ grades are quite evenly distributed in all size fractions. The weight percentage of coarse size is very large, nearly $45 \%$ with about $50 \%$ of total $\mathrm{MgO}$.

\subsubsection{Pure Dolomite Sample}

A pure dolomite sample was also collected from phosphate deposit in central Florida by IMC-Agrico Phosphate. The sample was taken from the bottom floor of the phosphate deposit by an experienced geologist. The as-received sample is in large particles which range from $50 \mathrm{~mm}$ to $150 \mathrm{~mm}$. The sample was crushed, ground and sized. The chemical analysis of each size fraction is presented in Table 3-2. It can be seen that the $\mathrm{MgO}$ content in each size fraction of sample Hs over 19\%. It indicates that the sample contains about $90 \%$ dolomite based on the fact that $\mathrm{MgO}$ content of pure dolomite sample Hs 21.58\%. The sample has very high $\mathrm{MgO}$ content which will be used as pure mineral for Hallimond cell flotation.

Table 3-2 Chemical analysis of pure dolomite samples

\begin{tabular}{|c|c|c|c|}
\hline \multirow{2}{*}{$\begin{array}{c}\text { Size } \\
\mu \mathrm{m}(\mathrm{mesh})\end{array}$} & \multicolumn{3}{|c|}{ Grade, \% } \\
\cline { 2 - 4 } & $\mathrm{MgO}$ & $\mathrm{P}_{2} \mathrm{O}_{5}$ & Acid Insol \\
\hline$-355+250(-42+60)$ & 19.52 & $<2$ & $<2$ \\
\hline$-250+150(-60+100)$ & 19.01 & $<2$ & $<2$ \\
\hline$-150+74(-100+200)$ & 19.26 & $<2$ & $<2$ \\
\hline$-74+38(-200+400)$ & 19.82 & $<2$ & $<2$ \\
\hline
\end{tabular}




\subsection{Reagents}

\subsubsection{Flotation Reagents}

FAS-40A: Saponated Fatty acid, a mixture of C-16 to C-20, was used as dolomite flotation collector. It was supplied by ARR-MAZ Products (Division of Process Chemicals, Winter Haven, Florida). The reagent is a brownish paste and soluble in water. It was prepared into a two percent solution for application.

PA-31: PA-31, a mixture of C-16 to C-20, was considered as the most effective fatty acid type collector for dolomite flotation. It was developed and produced by China Lianyungang Design and Research Institute (CLDRI). It was derived from saponification of cottonseeds oil residues boiled with sodium hydroxide. The saponated product was blended with 5\% surfactant to improve the properties of the collector for dolomite flotation. The reagent is a yellowish soap-like paste and water soluble. A two percent solution was prepared.

CCS-500 and CCS-550: Sulfonated fatty acid collectors were provided by ARR-MAZ Products (Division of Process Chemicals, Winter Haven, Florida). It is a brownish paste and water soluble. It was usually used for flotation of dolomite with deslimed feed. A two percent solution was prepared.

Amine AR-1051: Fatty acid amine was used as quartz collector, provided by ARR-MAZ products (Division of Process Chemicals, Winter Haven, Florida). The product is a light brownish liquid and has good solubility in water. A two percent solution was prepared for 
application.

Kerosene: Kerosene was used as a collector aid in amine flotation for separating silica from phosphate. It was supplied by Fisher Scientific (Pittsburgh, PA).

Phosphoric acid: $\mathrm{H}_{3} \mathrm{PO}_{4}$ was with chemical analysis grade having the purity of $85 \%$ $\mathrm{P}_{2} \mathrm{O}_{5}$ from Fisher Scientific (Pittsburgh, PA). It was used as both $\mathrm{pH}$ modifier and depressant of phosphate minerals in dolomitic phosphate flotation. A five percent solution was prepared for use in the experiment.

Sodium hydroxide: $\mathrm{NaOH}$ was supplied by Fisher Scientific (Pittsburgh, PA). It was used as a $\mathrm{pH}$ modifier to achieve alkaline $\mathrm{pH}$. A five percent solution was prepared for application.

\subsubsection{Surfactants}

Fatty acids are commonly used as collectors in flotation of oxide and salt-type minerals. They are also considered as surfactants to change the surface properties of the minerals. Surfactants mentioned in this work were the ones other than fatty acid type collectors. In this study, selected surfactants were applied to improve the flotation performance. Three surfactants were chosen in order to improve the separation of dolomite from phosphate in fatty acid flotation. They are diethyl phthalate (DP), Tween 80 (TW) and derivatives of sulfate salt (DSS1). 
Diethyl Phthalate: Diethyl phthalate (DP) is a nonionic surfactant. The chemical formula is $\mathrm{C}_{12} \mathrm{H}_{14} \mathrm{O}_{4}$ with molecular weight of $222.24 \mathrm{~g}$. Diethyl phthalate used in this study was provided by China Lianyungnag Design and Research Institute (CLDRI). It was dissolved in alcohol for application.

Tween-80: Tween-80 (Polyoxyethylene Sorbitan Monooleate) is a non-ionic detergent used for selective protein extraction and isolation of nuclei from mammalian cell lines with the chemical formula as $\mathrm{C}_{64} \mathrm{H}_{124} \mathrm{O}_{27}$ and the molecular weight of $1310 \mathrm{~g}$. It was ordered from Sigma-Aldrich, Inc., St. Louis, MO.

Derivatives of Sulfate Salt: Derivatives of sulfate salt (DSS1) is anionic surfactants widely used in detergent industry. It was supplied by Sigma-Aldrich, Inc., St. Louis, MO.

\subsection{Equipment and Experimental Methods}

\subsubsection{Grinding}

A laboratory Sparser rod mill was employed to grind the sample to minus $150 \mu \mathrm{m}$ (-100 mesh) for liberation of phosphate from gangue minerals, particularly from dolomite. The dimension of the rod mill was $200 \mathrm{~mm}$ ID and $250 \mathrm{~mm}$ length. For each sample, a series of grinding tests were carried out to determine the time period for obtaining the product passing $150 \mu \mathrm{m}$.

The as-received samples were air dried first. The dried samples were crushed to minus $1.18 \mathrm{~mm}$ (-14 mesh) through double roller crusher to achieve suitable size for 
grinding. The crushed samples were homogeneously mixed and stored in sealed containers.

A series of grinding tests were conducted to determine the grinding time to achieve sufficient liberation using $300 \mathrm{~g}$ and $1000 \mathrm{~g}$ samples respectively. The particle size distribution at different grinding time is presented in Tables 3-3 and 3-4 and 3-5, and plotted in Figs. 3-1, 3-2 and 3-3.

Table 3-3 Size distribution at different grinding time for $300 \mathrm{~g}$ dolomitic phosphate pebble sample $\mathrm{H}$

\begin{tabular}{|c|c|c|c|}
\hline \multirow{2}{*}{$\begin{array}{c}\text { Grinding Time } \\
(\mathrm{min})\end{array}$} & \multicolumn{3}{|c|}{ Wt.\% Passing } \\
\cline { 2 - 4 } & $\begin{array}{c}-150 \mu \mathrm{m} \\
(-100 \mathrm{mesh})\end{array}$ & $\begin{array}{c}-74 \mu \mathrm{m} \\
(-200 \mathrm{mesh})\end{array}$ & $\begin{array}{c}-38 \mu \mathrm{m} \\
(-400 \mathrm{mesh})\end{array}$ \\
\hline 2 & 50.26 & 19.13 & 11.47 \\
\hline 4 & 76.22 & 33.54 & 20.26 \\
\hline 6 & 98.98 & 58.23 & 32.63 \\
\hline 8 & - & 75.56 & 45.34 \\
\hline
\end{tabular}

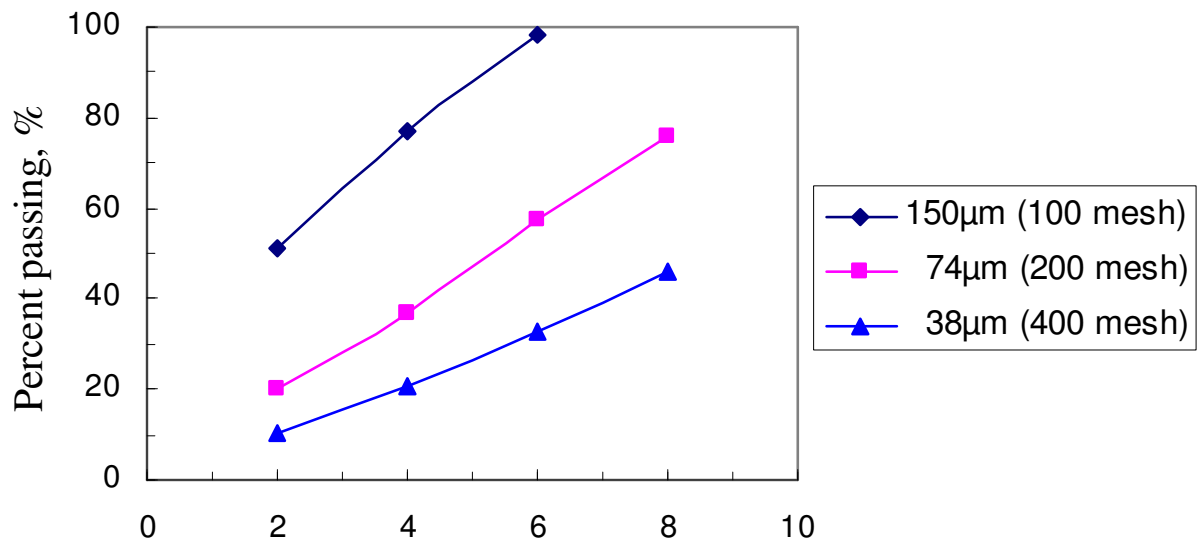

Grinding time, min.

Fig. 3-1 Percentage passing as a function of grinding time for $300 \mathrm{~g}$ sample $\mathrm{H}$ 
Table 3-4 Size distribution at different grinding time for $300 \mathrm{~g}$ dolomitic phosphate pebble sample $\mathrm{L}$

\begin{tabular}{|c|c|c|c|}
\hline \multirow{2}{*}{$\begin{array}{c}\text { Grinding } \\
\text { Time } \\
(\mathrm{min})\end{array}$} & \begin{tabular}{c}
$\mid 3$ \\
Wt.\% Passing \\
\cline { 2 - 4 }
\end{tabular} & $\begin{array}{c}-150 \mu \mathrm{m} \\
-74 \mu \mathrm{m}\end{array}$ & $\begin{array}{c}-38 \mu \mathrm{m} \\
(-400 \mathrm{mesh})\end{array}$ \\
\hline 4 & 68.45 & 41.64 & 25.20 \\
\hline 6 & 84.87 & 47.89 & 30.17 \\
\hline 8 & 96.31 & 56.18 & 36.27 \\
\hline 10 & 99.61 & 68.18 & 39.78 \\
\hline
\end{tabular}

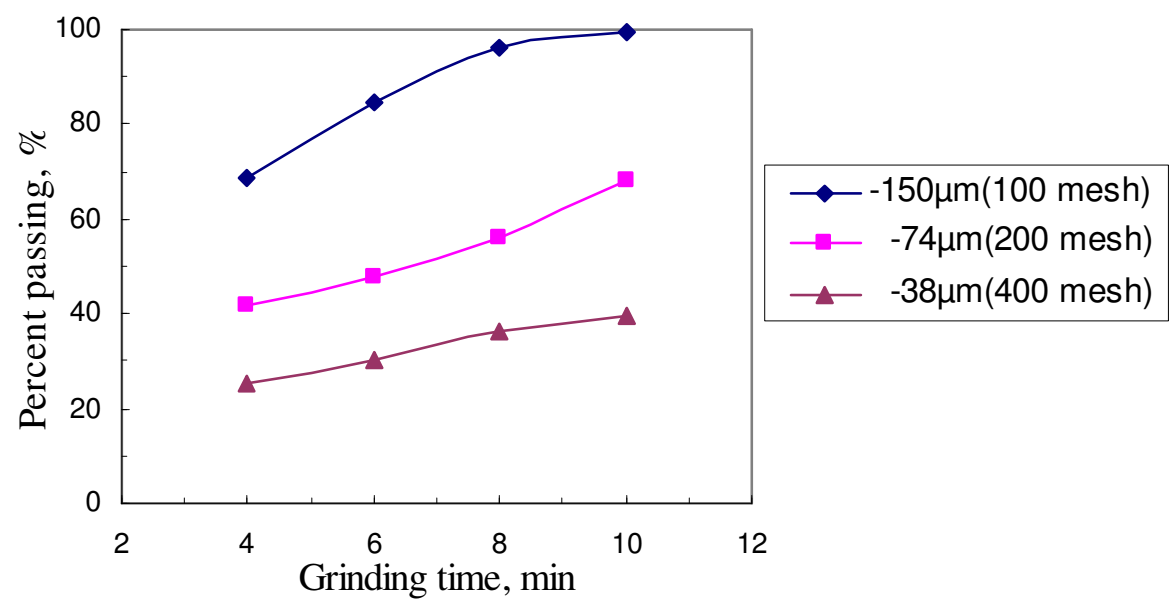

Fig. 3-2 Percentage passing as a function of grinding time for $300 \mathrm{~g} \mathrm{~B}$ sample

Table 3-5 Size distribution at different grinding time for $1000 \mathrm{~g}$ dolomitic phosphate pebble sample L

\begin{tabular}{|c|c|c|c|}
\hline \multirow{2}{*}{$\begin{array}{c}\text { Grinding Time } \\
\text { (min.) }\end{array}$} & \begin{tabular}{c}
$|c|$ \\
Wt.\% Passing \\
\cline { 2 - 4 }$(-100 \mathrm{mesh})$
\end{tabular} & $\begin{array}{c}-74 \mu \mathrm{m} \\
(-200 \mathrm{mesh})\end{array}$ & $\begin{array}{c}-38 \mu \mathrm{m} \\
(-400 \mathrm{mesh})\end{array}$ \\
\hline 10 & 68.09 & 40.13 & 27.24 \\
\hline 14 & 82.64 & 52.26 & 32.02 \\
\hline 18 & 9.81 & 63.54 & 40.11 \\
\hline 22 & & 76.19 & 48.25 \\
\hline
\end{tabular}




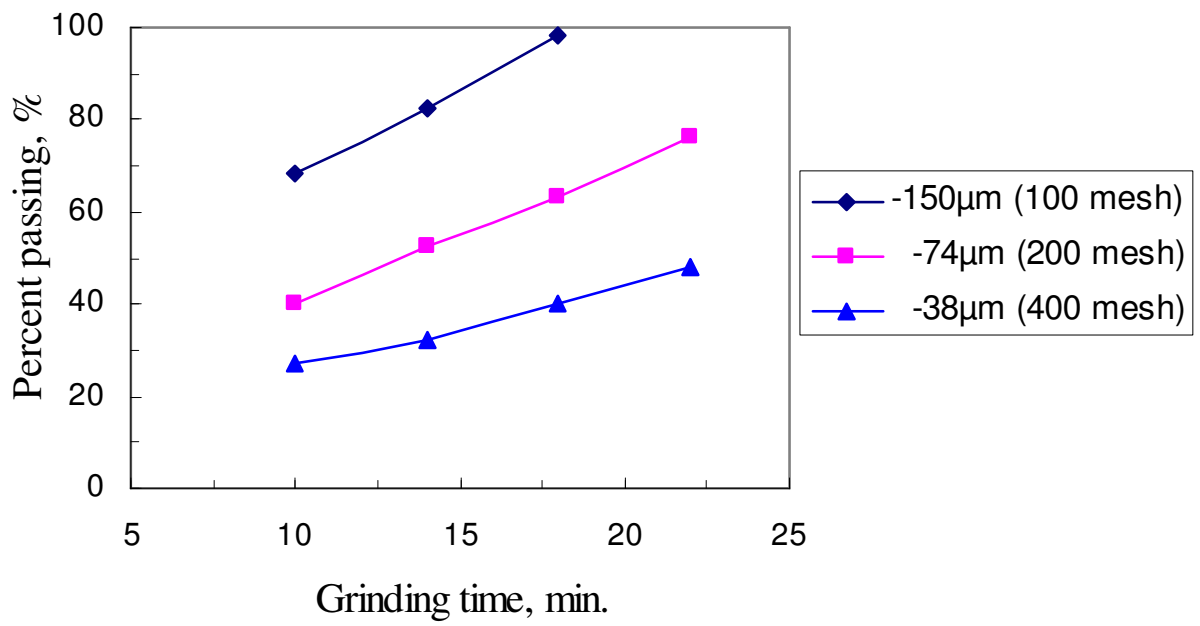

Fig. 3-3 Percentage passing as a function of grinding time for $1000 \mathrm{~g} \mathrm{~B}$ sample

Those grinding test figures indicate that the percentage passing at a given particle size increase with the grinding time. Comparisons of Figs. 3-4 and 3-5 shows that sample $\mathrm{H}$ has a steeper slope in the relationship between the percentage passing for a given particle size and grinding time sample L. To achieve same particle size of the material, longer grinding time is needed for sample L. This is because the sample $\mathrm{H}$ contains more carbonate minerals which is much softer than phosphate. It can also been seen that the smaller the sample size, the shorter grinding time to obtain the same percentage of a given size fraction. Six minutes was needed to produce $100 \%$ passing at $150 \mu \mathrm{m}$ size fraction for $300 \mathrm{~g}$ sample size, while it took 18 minutes to generate $100 \%$ passing at 150 $\mu \mathrm{m}$ size for $1000 \mathrm{~g}$ sample size for sample $\mathrm{L}$. 


\subsubsection{Frothability Measurement}

Froth flotation is a selective process for separating minerals from gangue by using surfactants and wetting agents. The selective separation of the minerals makes processing of complex orebodies economically feasible. The flotation method generally consists of three major steps: i) selective chemical modification of the surface of the specific mineral particles to change its floatability or non-floatability (hydrophobicity or hydrophilicity); ii) generation of relatively stable bubbles in a given size range and contact between air bubbles and mineral particles, the selective adherence of floatable minerals to those bubbles, and non-adherence of the non-floatable minerals to the bubble; and iii) separation of the floatable minerals from non-floatable materials. Among these three steps, frothers play very important role in the second and third steps by affecting particle-bubble attachment and influencing the degree of the separation during flotation. Frothers are chemical compounds that are used specifically for the purpose of creating proper froth layer in flotation separation. However, some collectors play the role as frother as well. In phosphate industry, the fatty acid reagents used in the dolomite or phosphate flotation serve these dual functions. Usually, there is no particular frother used to create froths in phosphate processing plants. The frothability of the fatty acid collector is very important for phosphate flotation. In this study, the frothability measurement of the fatty acid collector and its mixture with selected surfactants were carried out using a froth column meter described elsewhere (Peng and Xia, 2002). The froth column meter 
was made of $50.8 \mathrm{~mm}$ ID and $1500 \mathrm{~mm}$ height plexiglass cylindrical tube. The froth was generated by aerating a solution of collector using a fritted glass disc (sparger) at the bottom of the froth column. The fritted glass had a diameter of $20 \mathrm{~mm}$ with pores in size of $40-60 \mu \mathrm{m}$. The frothability was measured by the froth volume as a function of airflow rate and the concentration of fatty acid.

\subsubsection{Froth Stability Measurement}

A laboratory column in 60' height and 2' ID made from Perplex was used as the experimental apparatus for the froth stability measurement. FAS-40A alone and its mixture with $10 \%$ selected surfactants were studied as the frothing agents with the reagent concentration varied from 0.2 to $1.0 \mathrm{~g} / \mathrm{l}$. The experiments were carried out in the two phase system, i.e. air and water involved only. The air bubbles were produced using a fritted glass disc sparger mounted at the bottom of the froth column. The fritted glass had a diameter of $20 \mathrm{~mm}$ with pore in size of $40-60 \mu \mathrm{m}$. The solution was prepared in a 2 liter beaker and added to the froth column. The air was introduced into the froth column very slowly until the top surface of the bubbles reached a preset height and then air was completely shut off. The time period from shutting-off air until all bubbles disappeared was recorded as the lifetime of the froth which was used to express the froth stability. 


\subsubsection{Hallimond cell flotation Experiments}

Hallimond cell flotation experiments were conducted with a modified Hallimond cell (Fuerstenau, et al., 1957). This technique is widely used to measure the intrinsic floatability of relatively pure mineral samples. The advantages of Hallimond cell flotation include: i) less sample quantity required because only a few grams of sample Hs needed for each test; ii) obtaining test results very promptly because no chemical analysis is necessary on the products in most cases; iii) easy control of hydrodynamic parameters such as agitation strength, gas flow rate, reagent dosages, flotation time, etc.

In this study, the dolomite sample was crushed and sieved into several size fractions, $-300+250 \mu \mathrm{m}(-48+60 \mathrm{mesh}),-250+150 \mu \mathrm{m}(-60+100 \mathrm{mesh}),-150+74 \mu \mathrm{m}(-100+200$ mesh) and -74+38 $\mu \mathrm{m}(-200+400$ mesh). Each size fraction was also scrubbed in Denver flotation cell at the impeller speed of $1200 \mathrm{rpm}$ and then wet sieved in order to remove the extreme fines attached on the dolomite particles. Except for the size effect, all tests were run with the size fraction of $-250+150 \mu \mathrm{m}$. One gram of dolomite sample was used in each test. One gram sample was added into $100 \mathrm{ml}$ water. After the addition of the reagents, the slurry was conditioned for five minutes with a magnetic stirrer. After conditioning, the slurry was transferred into Hallimond cell. The material in the cell was stirred using a $10 \mathrm{~mm}$ telfon-coated magnetic stirring bar. Nitrogen gas was used for flotation at a flow rate of $1 \mathrm{ml} / \mathrm{sec}$. The Hallimond cell flotation assembly used in this study is illustrated in Fig. 3-1. 
After flotation time of 2 minutes, both float and sink fractions were filtered and dried at $75^{\circ} \mathrm{C}$, and then weighed. The recovery of the dolomite in the float was calculated with Eq. 3-1:

$$
\text { Dolomite recovery }=\mathrm{w}_{\mathrm{f}} /\left(\mathrm{w}_{\mathrm{f}}+\mathrm{w}_{\mathrm{s}}\right) \times 100 \%
$$

where $\mathrm{w}_{\mathrm{f}}$ is the weight of float; and $\mathrm{w}_{\mathrm{s}}$ is the weight of sink. 


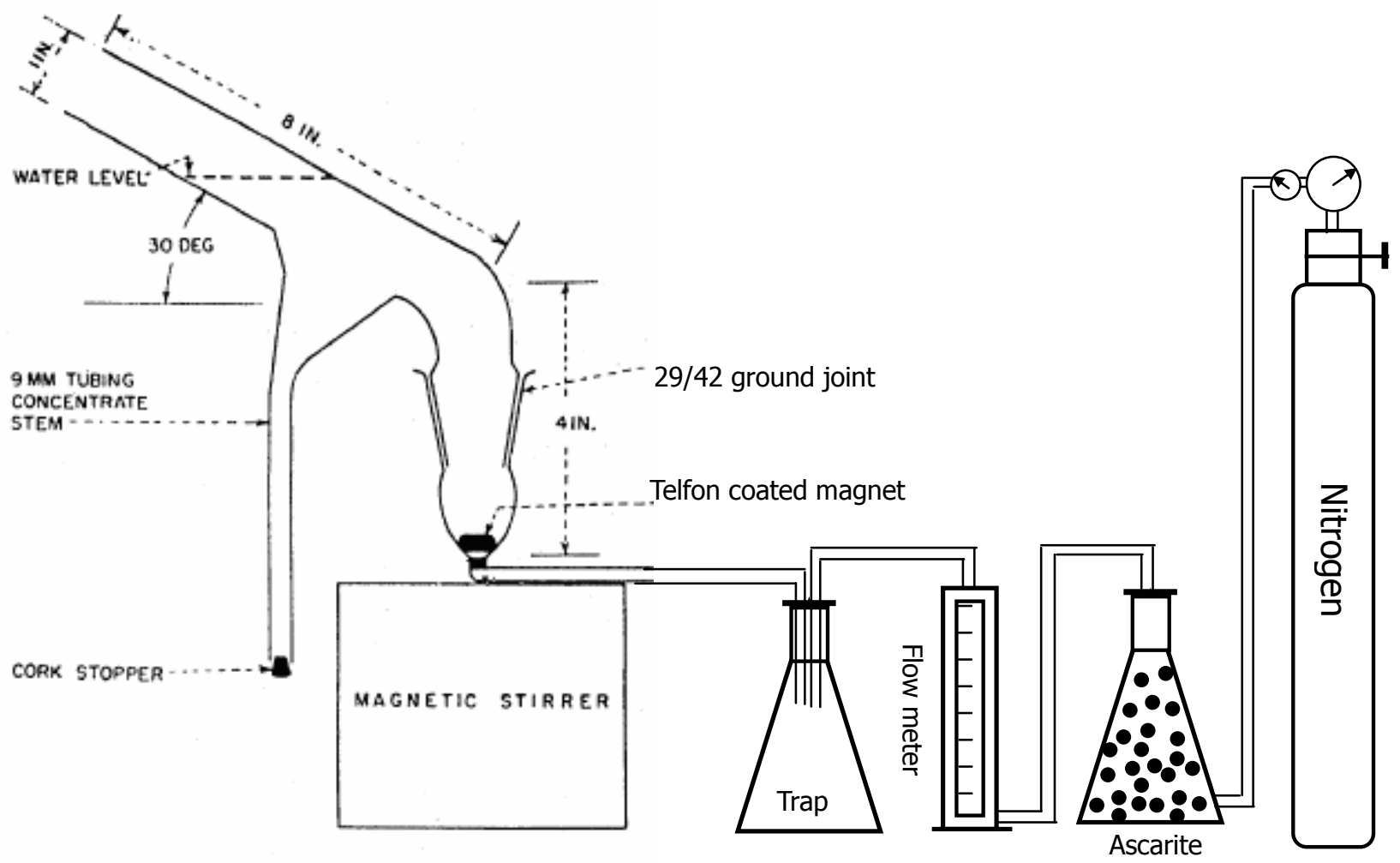

Fig. 3-4 Illustration of complete Hallimond cell flotation assembly 


\subsubsection{Batch Flotation Experiments}

Batch flotation tests on dolomitic phosphate ores were carried out with Denver D-12 model flotation machine and 1.2 liter cell. Three hundred grams dolomitic phosphate sample was wet ground to a given particle size for sufficient liberation. The milled slurry was adjusted to $1200 \mathrm{ml}$ pulp with $25 \%$ solid concentration. Phosphoric acid was used as both $\mathrm{pH}$ modifier and phosphate depressant. The slurry was conditioned with phosphoric acid for 1 minute. A predetermined amount of collector was added to the slurry and conditioned for two minutes. After conditioned with reagents, air was introduced to the flotation cell for one minute aeration. Flotation time was usually set for 6 minutes. All samples including float and sink were filtered, dried, weighed and analyzed. The float was dolomite tailings and the sink was the rougher concentrate.

Several indices needed to be computed based on the weight and chemical analysis results of the products to evaluate the effectiveness of the separation process. The yield of the float $\left(\mathrm{Y}_{\mathrm{f}}\right)$ was calculated from the weight of the flotation products:

$$
\mathrm{Y}_{\mathrm{f}}=\frac{\mathrm{w}_{\mathrm{f}}}{\mathrm{w}_{\mathrm{f}}+\mathrm{w}_{\mathrm{s}}} \times 100 \%
$$

where:

$\mathrm{Y}_{\mathrm{f}}=$ Yield of float, $\%$

$\mathrm{w}_{\mathrm{f}}=$ weight of float or overflow

$\mathrm{w}_{\mathrm{s}}=$ weight of sink or underflow 
Then, the yield of sink, $\mathrm{Y}_{\mathrm{s}}$ can be determined as:

$$
\mathrm{Y}_{\mathrm{s}}=100-\mathrm{Y}_{\mathrm{f}}
$$

The recovery of dolomite (as $\mathrm{MgO}$ ) in the float is defined as:

$$
\mathrm{R}_{\mathrm{df}}=\frac{\mathrm{Y}_{\mathrm{f}} \beta_{\mathrm{d}}}{\alpha_{\mathrm{d}}}(\%)
$$

where

$\mathrm{R}_{\mathrm{df}}=$ dolomite recovery in float, $\%$

$\mathrm{Y}_{\mathrm{f}}=$ yield of float, \%

$\beta_{\mathrm{d}}=\mathrm{MgO}$ grade in float, $\%$

$\alpha_{\mathrm{d}}=\mathrm{MgO}$ grade in feed, $\%$

Correspondingly, the dolomite recovery in the sink $\left(\mathrm{R}_{\mathrm{df}}\right)$ will be:

$$
\mathrm{R}_{\mathrm{ds}}=100-\mathrm{R}_{\mathrm{df}}
$$

The phosphate recovery $\left(\right.$ as $\left.\mathrm{P}_{2} \mathrm{O}_{5}\right)$ in the sink is defined as:

$$
\mathrm{R}_{\mathrm{ps}}=\frac{\mathrm{Y}_{\mathrm{s}} \beta_{\mathrm{p}}}{\alpha_{\mathrm{p}}}(\%)
$$

where

$\mathrm{R}_{\mathrm{ps}}=$ phosphate recovery in the sink, $\%$

$\mathrm{Y}_{\mathrm{s}}=\mathrm{yield}$ of sink, $\%$

$\beta_{\mathrm{p}}: \mathrm{P}_{2} \mathrm{O}_{5}$ grade in the sink, $\%$

$\alpha_{\mathrm{p}}: \mathrm{P}_{2} \mathrm{O}_{5}$ grade in the feed, \%

The phosphate recovery in the float will be:

$$
\mathrm{R}_{\mathrm{pf}}=100-\mathrm{R}_{\mathrm{ps}}
$$


The objective of dolomite flotation was to reject as much dolomite as possible into the float and to recover as much phosphate as possible in the sink with highest $\mathrm{P}_{2} \mathrm{O}_{5}$ grade and lowest $\mathrm{MgO}$ content. In order to evaluate the separation performance of dolomite flotation, selectivity index (SI) of separating dolomite from phosphate was defined as an comprehensive evaluation criterion by considering $\mathrm{P}_{2} \mathrm{O}_{5}$ grade, $\mathrm{P}_{2} \mathrm{O}_{5}$ recovery and $\mathrm{MgO}$ recovery in the underflow. Its definition is:

$$
\mathrm{SI}=\sqrt{\mathrm{R}_{\mathrm{ps}} \times\left(\mathrm{R}_{\mathrm{ps}}-\mathrm{R}_{\mathrm{ds}}\right) \times \beta_{\mathrm{ps}} / \beta_{\mathrm{pmax}}}
$$

where

SI=selectivity index of separating dolomite from phosphate;

$\mathrm{R}_{\mathrm{ps}}=$ phosphate recovery in the sink;

$\mathrm{R}_{\mathrm{ds}}=$ dolomite recovery in the sink;

$\beta_{\mathrm{ps}}=\mathrm{P}_{2} \mathrm{O}_{5}$ grade in the sink;

$\beta_{\text {pmax }}=$ theoretical $\mathrm{P}_{2} \mathrm{O}_{5}$ grade of phosphate mineral in the ore.

The mineralogical analysis showed that the theoretical $\mathrm{P}_{2} \mathrm{O}_{5}$ grade of pure phosphate minerals in Florida phosphate ores was about 36\%. In Eq. (3-8), when more phosphate is recovered and more dolomite is rejected, SI value will increase. Higher $\mathrm{P}_{2} \mathrm{O}_{5}$ grade in concentrate also increases the value of SI. The value of SI ranges from 0 to 100 . The value of SI is zero if there is no selective separation of dolomite from phosphate, i.e., in case of no flotation. If the value of SI equals 100, that means all phosphate mineral is recovered at a pure grade and all impurities are removed. Eq. (3-8) will be invalid if $R_{p s}$ is smaller than $\mathrm{R}_{\mathrm{ds}}$. In such a case, the operation is phosphate flotation rather than dolomite 
flotation. SI as a criterion was specifically defined for evaluating the separation of dolomite from phosphate for dolomite flotation.

\subsubsection{Modified Packed Column Flotation}

The flotation tests were carried out in a 2 inch ID and $6 \mathrm{ft}$ high packed column. The packing material is made of 0.002 inch thickness stainless steel corrugated plates. Each plate has $3 / 4$ " pitch running diagonally at $45^{\circ}$ angle. The packed column flotation system is schematically presented in Fig. 3-5. The packed flotation column is designed to incorporate a packed bed inside an open column to provide smaller and longer torturous flow passages for sufficient time for particle/bubble contact. The packing structure is to stack up the corrugated plates as shown in Fig. 3-5. The packing plates are arranged in blocks positioned in layers at right angles to each other. These stacked corrugated plates generated bubbles in the packed column and eliminates the need for the air sparger for flotation separation of the feed with high quantity of hydrophobic materials (Yang, 1991). The compressed air enters into the bottom of the column and the bubbles are generated by snarling between packing plates, and plates and wall. The large bubbles generated deformed between plates in order to pass through the winding narrow paths. No small or fine bubble generation was observed in this study. Due to low $\mathrm{MgO}$ content in sample $\mathrm{L}$, a sparger was installed inside the packed column in order to generate small bubbles and to form a stable froth layer.

The packed flotation column has a feed slurry inlet at the middle location, a water 
inlet at the top for spraying wash water into the column to rinse the froth, and an inlet at the bottom of the column for introducing compressed air to generate bubbles. Washing water goes down through a maze of flow passages confined by the packing structure. As air passes through the sparger, small bubbles are generated and continuously carry the hydrophobic particles into the froth zone in the upper portion of the column, when the hydrophilic particles as the sink product are discharged through the outlet at the bottom of the column. Capillary effects between the packing plates support a controllable froth height if there are sufficient bubbles. This effect makes a deep froth column flotation achievable, when the high number of hydrophobic particles is present in the pulp. Washing water detaches the entrained mineral particles in the froth. The slurry level or the froth interface in the modified structured plate column is controlled by adjusting the height of the tubing for the underflow discharge. 


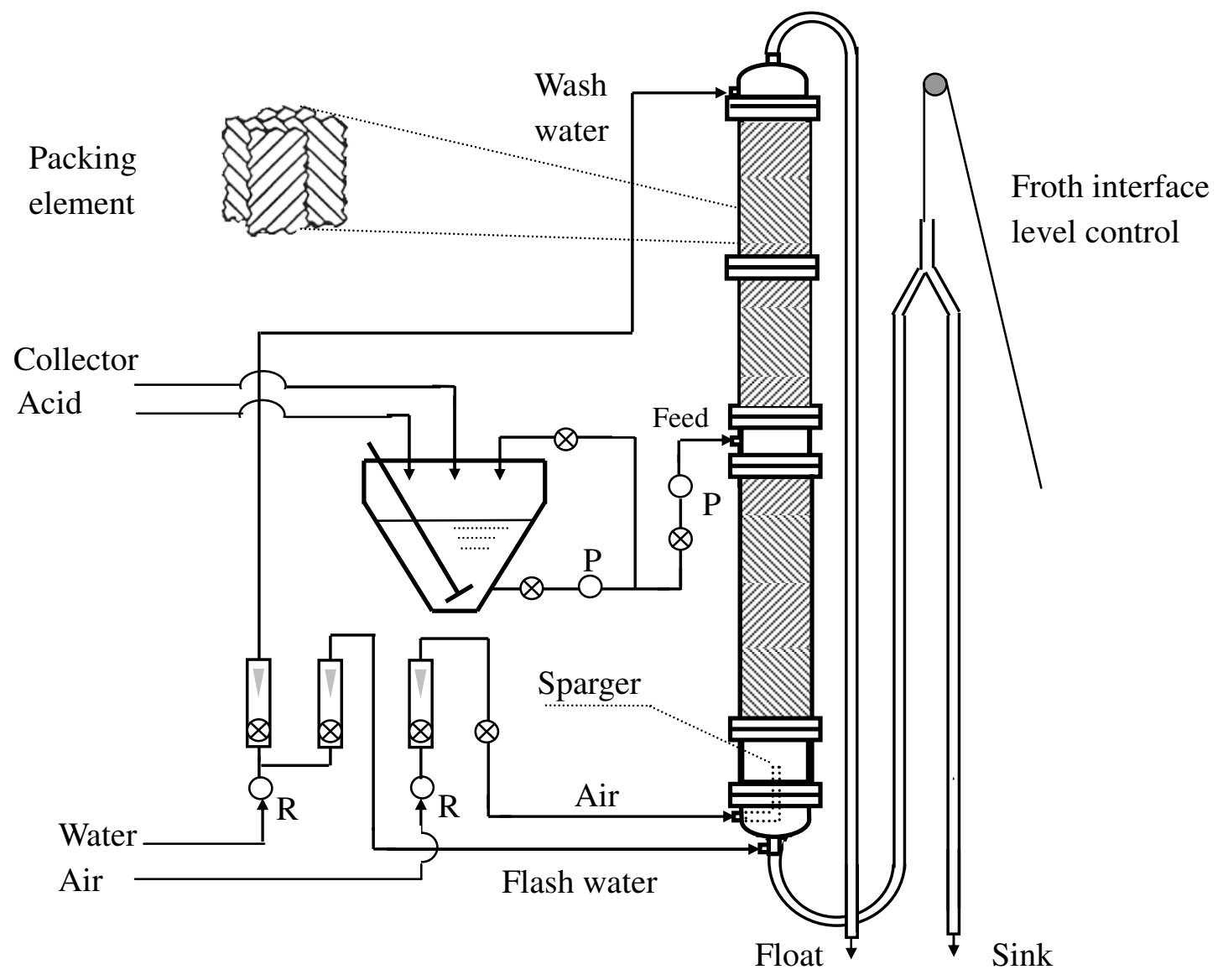

Fig. 3-5 Schematic diagram of 2-in ID modified packed flotation column system

The feed slurry was prepared by adding at least five batches of 1000 grams milled samples into the conditioning tank. The slurry was diluted to a desired solid percentage. The slurry was continuously stirred in the tank to maintain the particles in suspension and was circulated through a circulation loop with a pump to achieve the homogeneity of the suspension. The phosphoric acid was added to the agitation tank to adjust $\mathrm{pH}$. The collector was also added into the tank after the $\mathrm{pH}$ adjustment. This slurry was fed at 
about 3 feet from the bottom of the modified packed column. During the experiment, the slurry was conditioned for at least 20 minutes whenever an operation parameter was changed. The overflow and underflow products were collected simultaneously for a given period, usually one minute. The collected samples were filtered, dried, weighed and analyzed. The weight and analysis data were used for the determination of the yields, grades and recoveries of the products in the process.

Based on previous research (Gu, 2002), four parameters were selected in this study. They were flotation $\mathrm{pH}$, collector dosage, froth height and air flow rate. Central composite design (CCD) method was employed to study the effects of parameters. The standard statistics software, JMP v.4, (SAS Institute Inc., Cary, NC) was applied. Based on the output of JMP program, 26 runs were required for the central composite design of four factor experiment. After the completion of all 26 runs, selectivity index was calculated according to Eq. 3-8. The selectivity index was used as the experiment responses and as the input to JMP for statistical analysis. 


\section{CHAPTER 4 RESULTS AND DISCUSSIONS}

\subsection{Measurement of Frothability and Froth Stability}

Flotation kinetics involves a number of mass transfer processes which take place in the slurry stage such as mineral particle-bubble collision and attachment, and movement of the mineralized bubble aggregates to the froth stage. Some processes occur in the froth stage such as recleaning of valuable minerals in froth zone and recovery of mineral particles from froth zone as concentrate. All those sub-processes depend strongly on frothability, and bubble size and froth stability. In this study, the effects of selected surfactants on frothability and froth stability are investigated.

\subsubsection{Effect of Selected Surfactants on Collector Frothability}

In the froth flotation process, minerals are conditioned with inorganic reagents to adjust flotation $\mathrm{pH}$, and organic reagents such as collector to alter the surface properties of the particles. Air is introduced to the flotation system for generating bubbles to carry the hydrophobic particles upwards. Thus, the selective separation of valuable minerals from gangues is made by moving hydrophobic particles to the overflow and keeping hydrophilic particles in the underflow. In order to produce enough bubbles having reasonable stability, frothers are usually used to control the surface tension of water, and the quantity and size of bubbles. For example, pine oil is widely used in mineral 
processing industry and methyl isobutyl carbinol (MIBC) is used in coal preparation plants. However, in phosphate industry, fatty acid is commonly used as collector for either phosphate or carbonate flotation and there is no frother applied separately to control the bubble generation. For example, in Florida, the phosphate ore is sized into three fractions, plus $1 \mathrm{~mm}$ as pebble, minus 1 plus $0.1 \mathrm{~mm}$ as flotation feed, and minus $0.1 \mathrm{~mm}$ as slimes. The minus 1 plus $0.1 \mathrm{~mm}$ fraction is conditioned with soda ash to control $\mathrm{pH}$, fatty acid as collector and fuel oil as collector aid to float phosphate. The rougher phosphate concentrate is washed with sulfuric acid and then dewatered in an attempt to remove the fatty acid adsorbed on the surfaces of phosphate and quartz particles. The acid-washed material is subjected to silica flotation using amine as collector. The underflow of silica flotation is the final phosphate concentrate that is ready for downstream application. In a 2.5 million tons/year capacity dolomitic phosphate processing plant in China, the ore containing $4.0-4.5 \% \mathrm{MgO}$ and 29 to $30 \% \mathrm{P}_{2} \mathrm{O}_{5}$ is wet ground to a particle size of $60 \%$ passing $75 \mu \mathrm{m}$ (200 mesh). It is conditioned with sulfuric acid to adjust $\mathrm{pH}$ at 5.0 to 5.5 , a fatty acid type collector is used to float dolomite. The final phosphate concentrate contains $35 \% \mathrm{P}_{2} \mathrm{O}_{5}$ and $0.95 \% \mathrm{MgO}$ at the overall recovery of more than 90\% (Gao and Gu, 1999; Lu and Sun, 1999). Laboratory studies and plant practices demonstrated that the fatty acid type collector plays dual functions and works as both collecting and frothing agent in either direct flotation or reverse flotation in phosphate industry. There is very little literature discussing the effect of frothabilty of fatty acid type collectors on dolomite or phosphate flotation. 
In this study, the effects of three selected surfactants, diethyl phthalate (DP), Tween-80 (TW) and sulfonate derivatives (DSS1) on the frothability of a fatty acid collector, FAS-40A, were evaluated by measuring the froth height at different reagent dosages and air flow rate. Fig. 4-1 shows the frothability of fatty acid collector FAS-40A at different dosages and air flow rate. It can be observed that the froth height of FAS-40A alone increases almost linearly with reagent dosage at air flow rate greater than 0.05 L/min. Figs. 4-2, 4-3 and 4-4 show the effect of the surfactant at various percentages on the frothability of FAS-40A at the dosage of $0.4 \mathrm{~g} / 1$. The increase of surfactant percentage from $0 \%$ to $10 \%$ of the fatty acid collector in the mixture results in increasing the froth height. The results show that the addition of surfactant can improve the frothability of the fatty acid collector. However, it is noted that when DSS1 dosage is $10 \%$ of FAS-40A collector, the frothability can be significantly improved compared to that of DP and TW additions. 


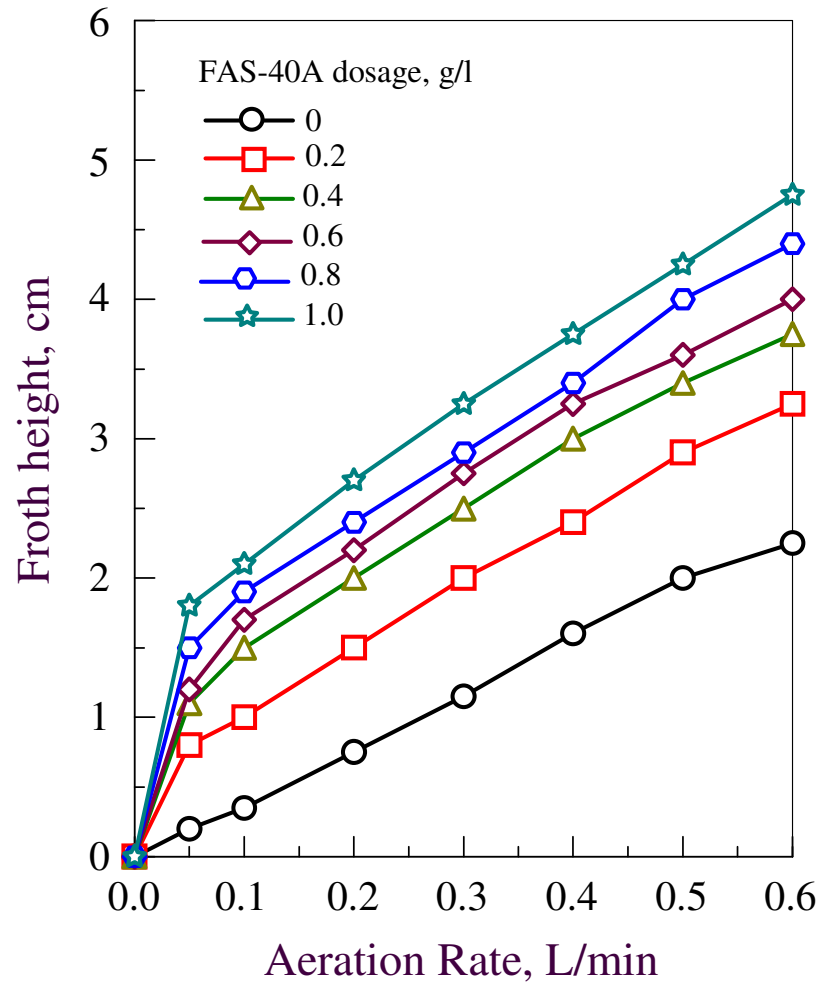

Fig. 4-1 Froth height as a function of aeration rate at various FAS-40A dosage 


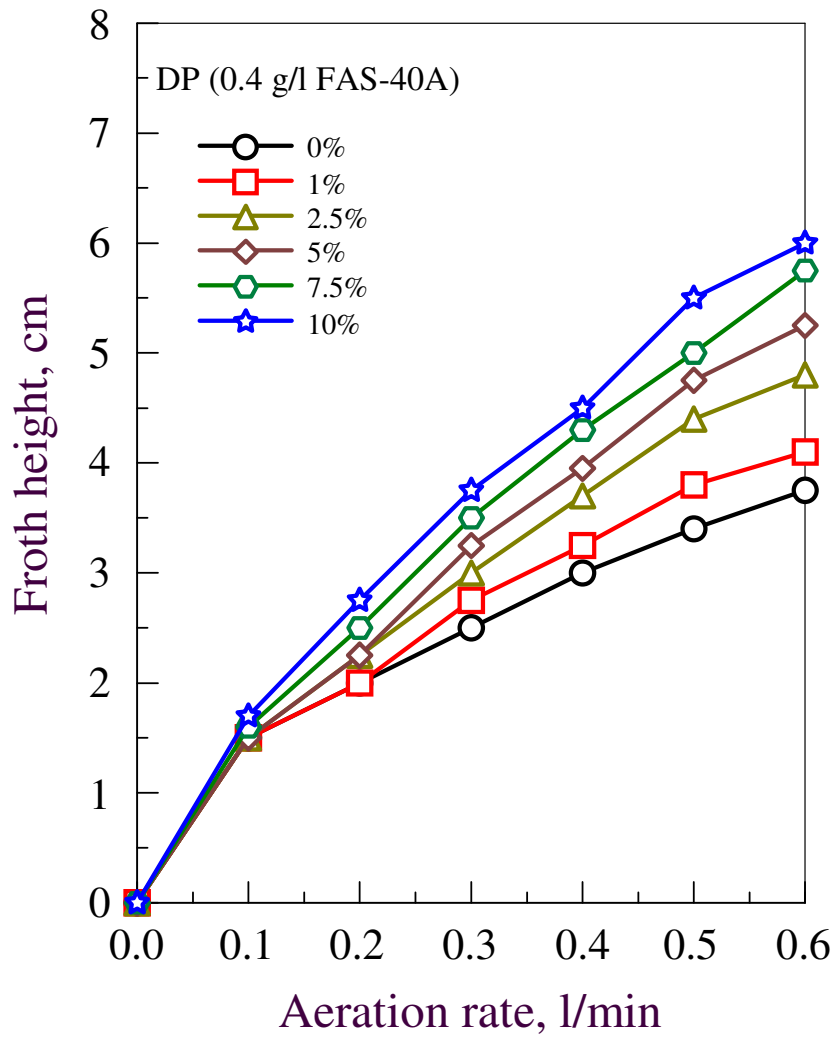

Fig. 4-2 Froth height as a function of aeration rate at $0.4 \mathrm{~g} / 1 \mathrm{AS}-40 \mathrm{~A}$ with different percentage of DP 


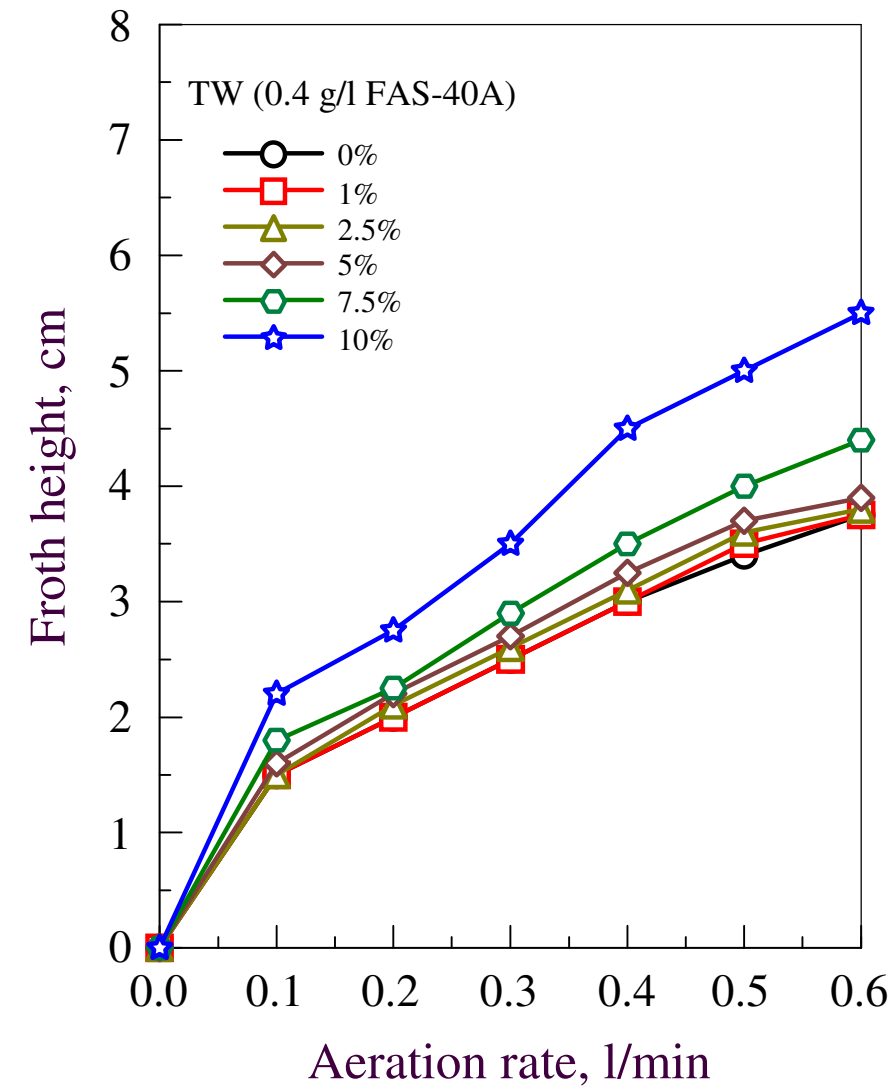

Fig. 4-3 Froth height as a function of aeration rate at $0.4 \mathrm{~g} / \mathrm{l} \mathrm{FAS-40A}$ with different percentage of TW 


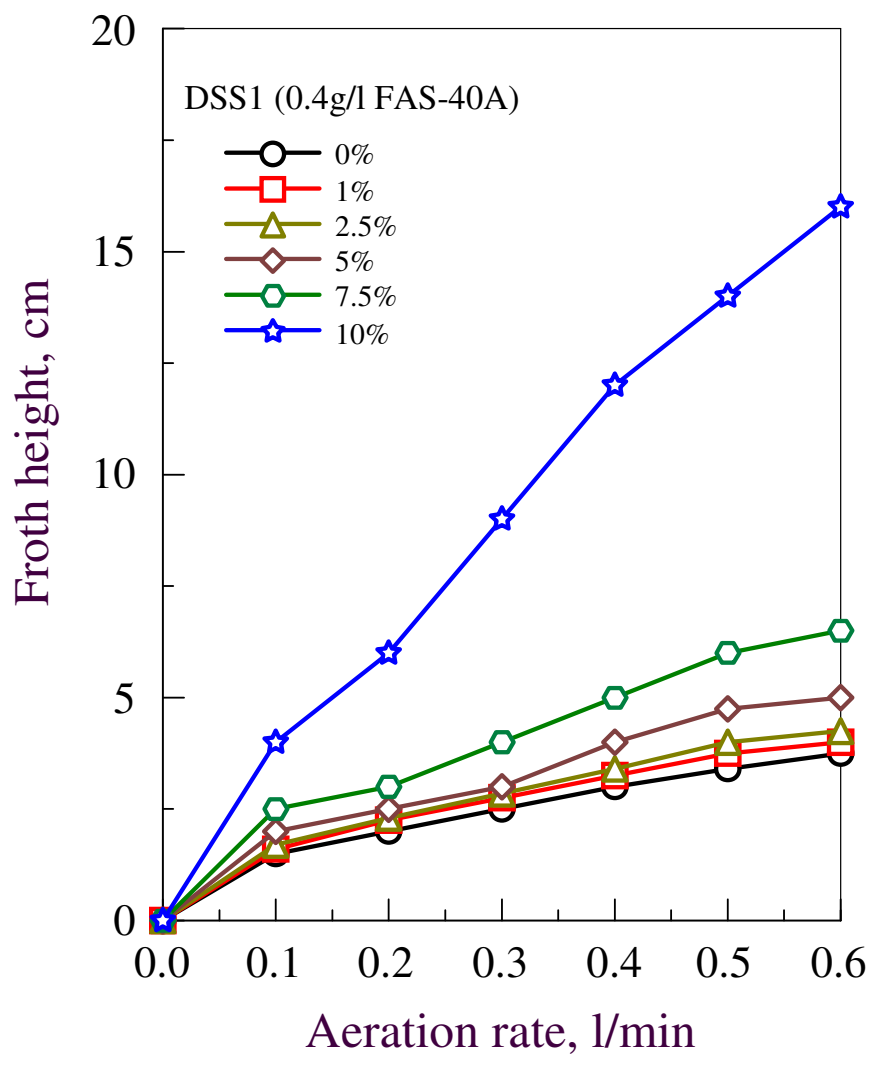

Fig. 4-4 Froth height as a function of aeration rate at $0.4 \mathrm{~g} / \mathrm{l} \mathrm{FAS}-40 \mathrm{~A}$ with different percentage of DSS1

The relationship of froth height and aeration rate at various reagent dosages can be described by the following expressions (Dey and Bhattacharya, 1998; Peng and Xia, 2002):

$$
\begin{aligned}
& \mathrm{H}=\mathrm{H}_{0}\left(1-\exp \left(-\mathrm{K}_{\mathrm{f}} \mathrm{Q}\right)\right) \\
& \mathrm{AH}=\mathrm{AH}_{0}\left(1-\exp \left(-\mathrm{K}_{\mathrm{f}} \mathrm{Q}\right)\right)
\end{aligned}
$$

where $\mathrm{H}$ is froth height, $\mathrm{cm}$, at aeration rate $\mathrm{Q}, \mathrm{mL} / \mathrm{min} ; \mathrm{H}_{0}$ is ultimate froth height, $\mathrm{cm}$; 
$\mathrm{K}_{\mathrm{f}}$ is a froth volume constant, $\mathrm{min} / \mathrm{mL}$ and $\mathrm{A}$ is the cross sectional area of the column, $\mathrm{cm}^{2}$. The parameters of Equations (4-1a) and (4-1b) for the fatty acid collectors and distilled water are estimated using PSIPLOT software (Poly Software int'l, Sandy, UT) and given in Table 4-1.

From Eqs. (4-1a) and (4-1b), the instantaneous retention time, Rt, can then be derived as

$$
R t=\frac{d(A H)}{d Q}=A \frac{d H}{d Q}=A H_{0} K_{f} \exp \left(-K_{f} Q\right)
$$

when $\mathrm{Q}->0$, Rt will reach to the maximum value of $\mathrm{AH}_{0} \mathrm{~K}_{0}$, which is initial retention time, IRT. IRT characterizes the frothability at a given concentration only. The relationship between IRT and reagent dosage can be expressed by

$$
\text { IRT }- \text { IRT }_{\text {water }}=\operatorname{IRT}_{\infty}\left(1-\exp \left(-\mathrm{K}_{\mathrm{d}} \mathrm{C}\right)\right)
$$

where IRT $\infty$ is the limiting value of IRT for $\mathrm{C}->0$; $\mathrm{C}$ is the concentration of collector and $\mathrm{K}_{\mathrm{d}}$ is a concentration constant. In this special case, a new relationship between IRT and reagent dosage is defined as follows:

$$
\text { IRT } \left.-\mathrm{IRT}_{\text {water }}=\mathrm{IRT}_{\infty} * \exp \left(-\mathrm{K}_{\mathrm{d}} \mathrm{C}\right)\right)
$$

Fig. 4-3 shows the initial retention time as a function of collector dosage. The solid line represents the best fitting of Eq. (4-3) to the experiment points. A new parameter, initial dynamic froth index, IDFI has been defined to describe the frothability characteristics of the reagents by Peng and Xia (2002). The IDFI can be obtained by following equation: 


$$
\mathrm{IDFI}=\left(\frac{\partial(\mathrm{IRT})}{\partial \mathrm{C}}\right)_{\mathrm{c} \rightarrow 0}=\mathrm{IRT}_{\infty} \mathrm{K}_{\mathrm{d}}
$$

The values of the initial dynamic frothability index and ultimate initial retention time can be computed from above Equations. The results are presented in Table 4-1. The product of the IDFI and collector concentration provides the information of the frothing properties for the reagents studied under dynamic steady state conditions. It can be seen that at the same dosage of FAS-40A, DSS1 has large value of IDFI as well as IDFI*C. The experiment results show that DSS1 can significantly improve the frothability of the fatty acid collector compared to other two surfactants DP and TW. 
Table 4-1 Ultimate froth height and volume constant as a function of froth concentration

\begin{tabular}{|c|c|c|c|c|c|c|c|}
\hline Surfactant & $\begin{array}{c}\text { FAS-40A } \\
\text { +surfactant } \\
(\mathrm{g} / \mathrm{L})\end{array}$ & $\begin{array}{c}\text { Surfactant } \\
(\%)\end{array}$ & $\begin{array}{c}\text { Ultimate } \\
\text { froth } \\
\text { height } \\
\mathrm{H}_{0}(\mathrm{~cm})\end{array}$ & $\begin{array}{c}\text { Volume } \\
\text { constant } \\
\text { Kf } \\
(\mathrm{Min} / \mathrm{L})\end{array}$ & $\begin{array}{l}\text { IRT } \\
(\mathrm{s})\end{array}$ & $\begin{array}{c}\text { IDFI } \\
\text { (s.dm3/g) }\end{array}$ & IFDC $* \mathrm{C}$ \\
\hline \multirow{6}{*}{ DSS1 } & 0.4 & $0 \%$ & 4.19 & 3.34 & 17.01 & \multirow{6}{*}{61.66} & 24.66 \\
\hline & 0.404 & $1 \%$ & 4.43 & 3.58 & 19.28 & & 24.91 \\
\hline & 0.41 & $2.5 \%$ & 4.83 & 3.3 & 19.37 & & 25.28 \\
\hline & 0.42 & $5 \%$ & 6.27 & 2.61 & 19.89 & & 25.90 \\
\hline & 0.43 & $7.5 \%$ & 8.45 & 2.36 & 24.24 & & 26.51 \\
\hline & 0.44 & $10 \%$ & 35.67 & 1 & 43.36 & & 27.13 \\
\hline \multirow{6}{*}{ DP } & 0.4 & $0 \%$ & 4.19 & 3.34 & 17.01 & \multirow{6}{*}{49.22} & 19.69 \\
\hline & 0.404 & $1 \%$ & 5.03 & 2.74 & 16.75 & & 19.89 \\
\hline & 0.41 & $2.5 \%$ & 6.68 & 2.08 & 16.89 & & 20.18 \\
\hline & 0.42 & $5 \%$ & 8.26 & 1.68 & 16.87 & & 20.67 \\
\hline & 0.43 & $7.5 \%$ & 8.89 & 1.69 & 18.26 & & 21.16 \\
\hline & 0.44 & $10 \%$ & 8.95 & 1.84 & 20.02 & & 21.66 \\
\hline \multirow{6}{*}{ TW } & 0.4 & $0 \%$ & 4.19 & 3.34 & 17.01 & \multirow{6}{*}{51.39} & 20.56 \\
\hline & 0.404 & $1 \%$ & 4.27 & 3.25 & 16.87 & & 20.76 \\
\hline & 0.41 & $2.5 \%$ & 4.3 & 3.41 & 17.82 & & 21.07 \\
\hline & 0.42 & $5 \%$ & 4.32 & 3.66 & 19.22 & & 21.59 \\
\hline & 0.43 & $7.5 \%$ & 5.01 & 3.18 & 19.36 & & 22.10 \\
\hline & 0.44 & $10 \%$ & 6.49 & 2.95 & 23.27 & & 22.61 \\
\hline \multicolumn{3}{|c|}{ Distilled water } & 26.53 & 0.18 & 4.77 & & \\
\hline
\end{tabular}




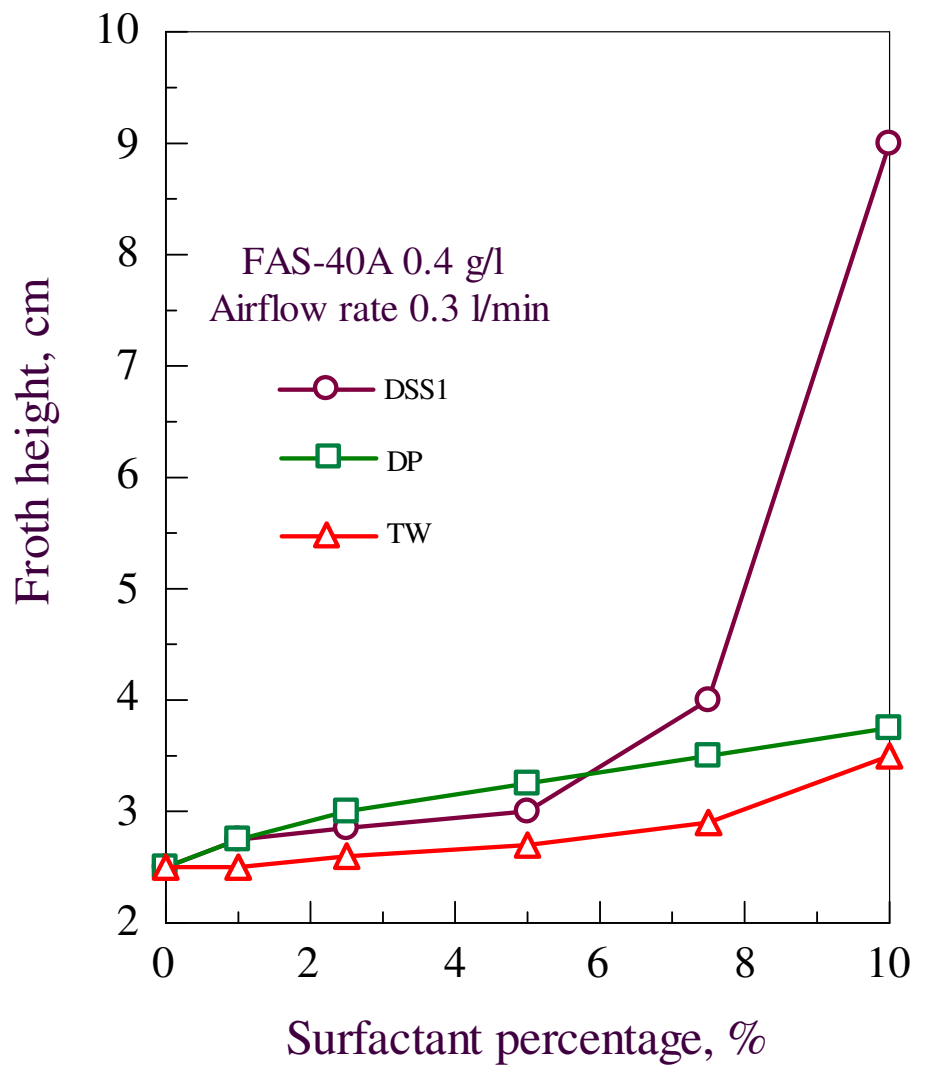

Fig. 4-5 Froth height as a function of surfactant percentage 


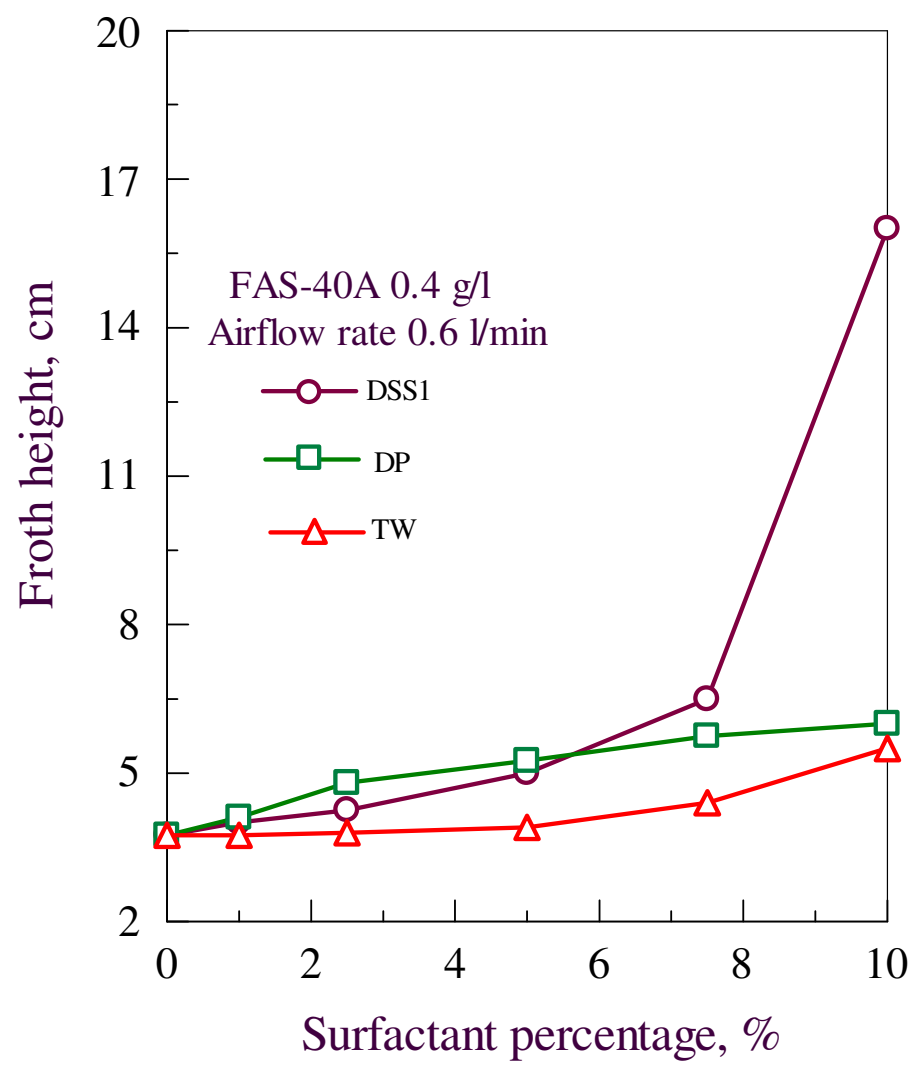

Fig. 4-6 Froth height as a function of the ratio of surfactant percentage

Figs. 4-5 and 4-6 plot the froth height as a function of surfactant percentage at air flow rate of 0.3 and 0.6 1/min. respectively. The tendencies of the corresponding curves in these two figures are quite similar except that the froth height at airflow rate of $0.6 \mathrm{l} / \mathrm{min}$. is much larger than that at $0.3 \mathrm{l} / \mathrm{min}$. Both figures show that at less than $5 \%$, DP has better frothability than TW and DSS1. When percentage passes $7.5 \%$, the froth height increases 
sharply with DSS1. The increase for DP and TW levels off with the increase of the surfactant percentage in the fatty acid collector FAS-40A.

\subsubsection{Effect of Selected Surfactants on Collector Froth Stability}

In mineral flotation, froth stability is one of the most important and critical factors for flotation performance. Unstable froth is easy to break and causes detachment of mineral particles from froth, which leads to low mineral recovery. Too stable froth causes difficulties in product transportation and dewatering. It will also increase the probability of the undesired particles to be entrapped into the float. Such entrapment will deteriorate the purity of the product if the float is the product, or it will cause the loss of valuable mineral particles into tailings which leads to low recovery. Using the approach described in Section 3.3.3, the froth lifetime for FAS-40A alone and its mixture of $10 \%$ selected surfactants were measured. The experimental data for froth lifetime measurement is presented in Fig. 4-7.

The froth lifetime as a function of collector dosage with and without the presence of $10 \%$ selected surfactants is plotted in Fig. 4-7. It shows that there is a slight increase in froth lifetime with the increase in dosage of FAS-40A alone. With the addition of $10 \%$ surfactant DP or TW into FAS-40A, the froth lasts longer than that without any surfactant. From Fig. 4-7, it can be observed that DSS1 has a significant effect on the stability of the froth. When surfactant DSS1 is used, the froth lifetime is much longer than using FAS-40A alone as well as using the mixture of FAS-40A with DP or TW. 


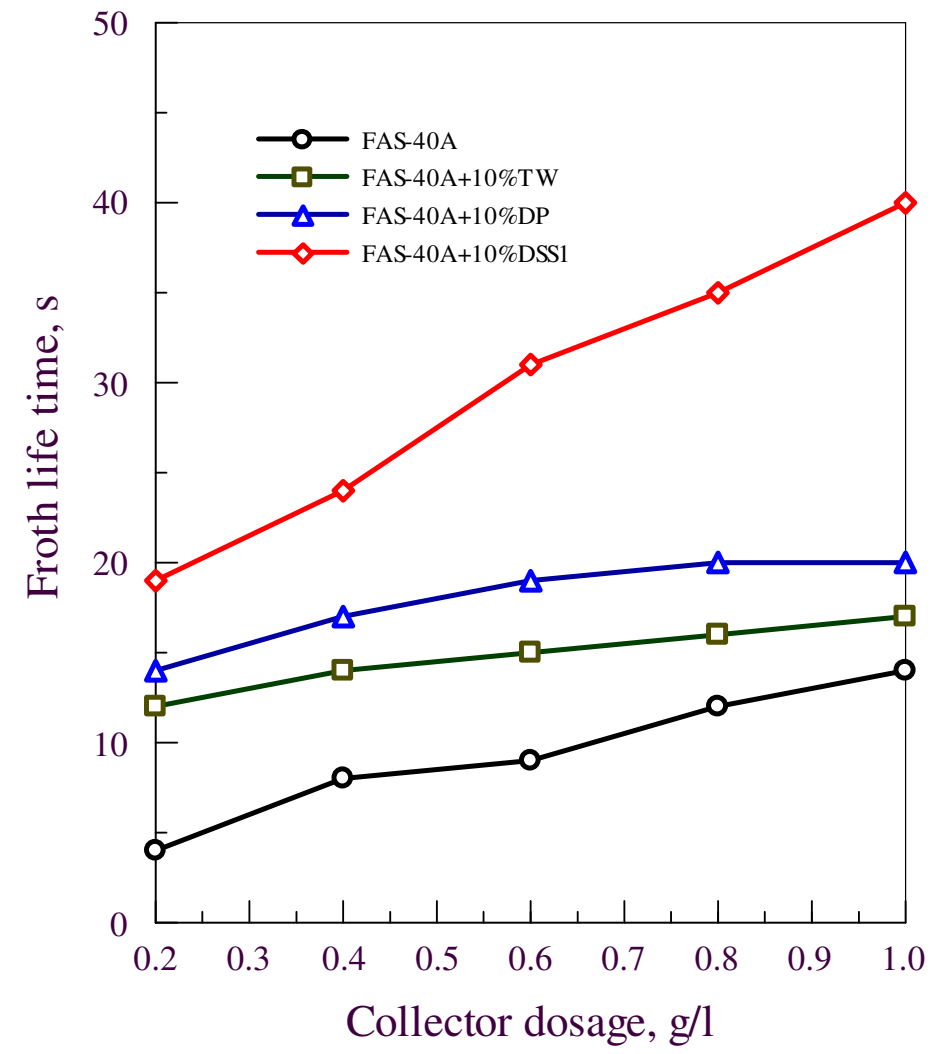

Fig. 4-7 Froth lifetime as a function of collector dosage measured at $1 \mathrm{l} / \mathrm{min}$. airflow rate 


\subsection{Hallimond cell flotation Experiments}

Hallimond cell flotation was conducted in a Hallimond tube with one gram of dolomite sample for each test. Dolomite collector FAS-40A and three surfactants, derivative of sulfate salt (DSS1), Tween-80 (TW) and dethyl phthalate (DP) were selected and used in dolomite flotation. Hallimond cell flotation experiments were designed to evaluate the effectiveness of each surfactant in dolomite flotation. Following factors were investigated in the Hallimond cell flotation, including reagent dosage effect

on dolomite flotation, effect of presence of $\mathrm{Ca}^{2+}$ ions, effect of fine slimes, and effect of particle size of flotation feed.

\subsubsection{Effect of Reagent Dosages on Dolomite Flotation}

Hallimond cell flotation tests were carried out in the the presence and absence of $10 \%$ surfactants in dolomite flotation collector and the results are plotted in Fig. 4-8. 


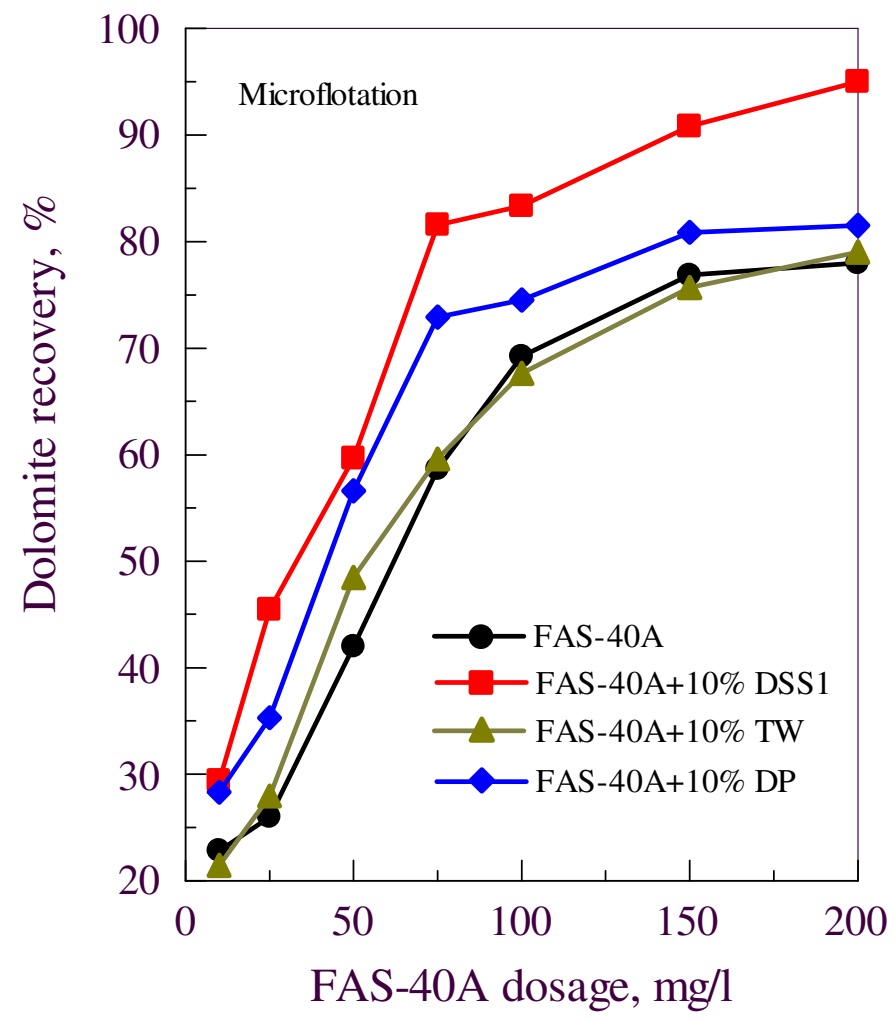

Fig. 4-8 Dolomite recovery as a function of collector dosages in the presence and absence of surfactants

By using dolomite collector FAS-40A alone, the dolomite recovery increases with the increase of the collector dosages. In the presence of surfactants, the similar pattern of dolomite recovery curves has been observed. For $10 \%$ of TW addition, the dolomite recovery curve was almost the same as that of using FAS-40A alone. The addition of DSS1 increased the dolomite recovery significantly. At $75 \mathrm{mg} / \mathrm{l}$ of FAS-40A, the dolomite recovery without surfactant was only $58 \%$. When same dosage of FAS-40A was used with $10 \%$ DSS1, i.e. $7.5 \mathrm{mg} / \mathrm{l}$, the dolomite recovery was increased by $24 \%$, up to $82 \%$. It can be seen that DSS1 has significantly enhanced the collecting ability of 
FAS-40A on dolomite flotation. The addition of $10 \%$ of DP to the FAS-40A collector can also increase the dolomite recovery. The magnitude of the increase in the recovery is in between DSS1 and TW.

The effect of surfactant percentage in the mixture of surfactant and FAS-40A was also tested in the Hallimond tube Hallimond cell flotation. The FAS-40A dosage was fixed at $50 \mathrm{mg} / \mathrm{L}$. The surfactant dosages were $2.5,5,10,15$ and $20 \%$ of the FAS-40A, respectively. The test results show that the dolomite recovery went up as the ratio of surfactant to FAS-40A increased for all the three surfactants. The magnitude of the increment is in the order of DSS1 $>\mathrm{DP}>\mathrm{TW}$. 


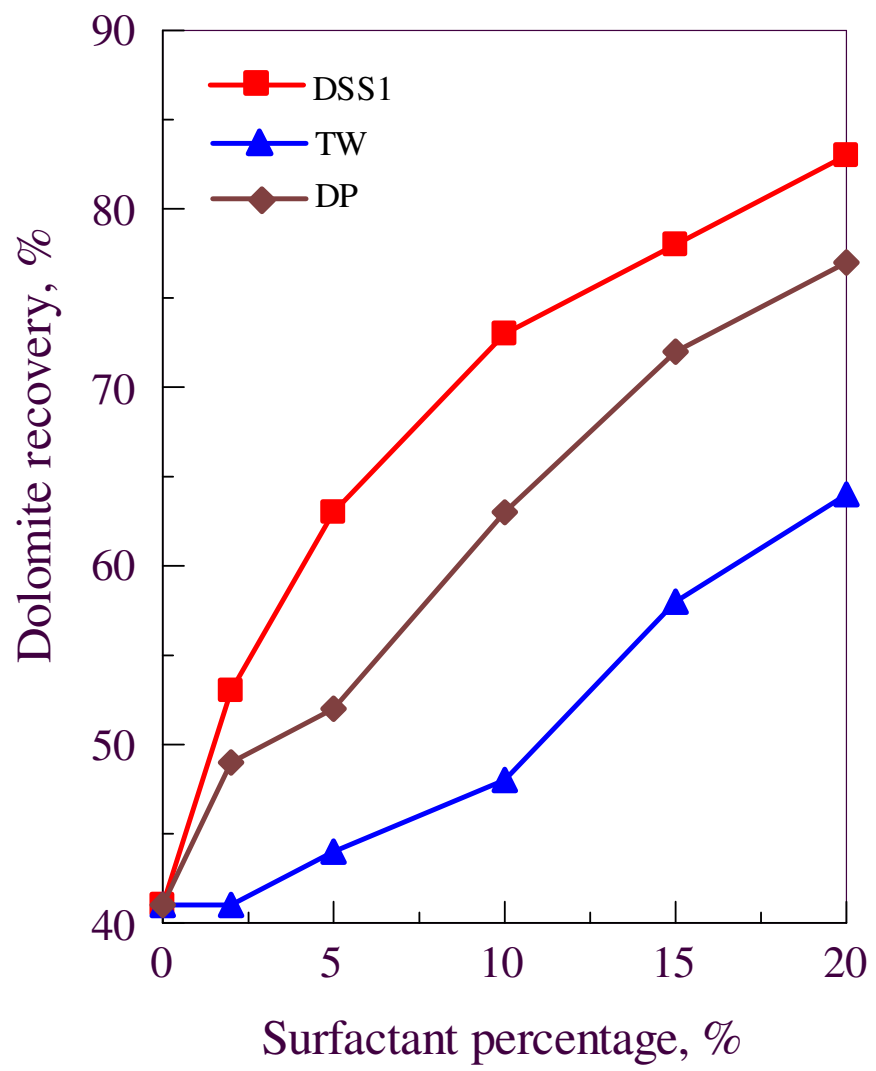

Fig. 4-9 Dolomite recovery as a function of the ratio of the surfactant percentage to

FAS-40A

\subsubsection{Effect of Calcium Ions on Dolomite Flotation}

Hallimond tube micro flotation tests were conducted in the presence and absence of calcium ions and the results are plotted in Figs. 4-10, 4-11, 4-12 and 4-13. Fig. 4-10 shows the effect of calcium ions on dolomite flotation using FAS-40A as a collector. It can be seen that there is not much difference in dolomite recovery in the absence and presence of $100 \mathrm{ppm}$ calcium ions. However, using the mixture of FAS-40A and other surfactants can improve dolomite recovery in the float in the presence of $100 \mathrm{ppm} \mathrm{Ca}^{2+}$ 
ions as illustrated in Figs. 4-11, 4-12, and 4-13. The magnitude of such improvement in dolomite recovery for the selected surfactants is in the order of DSS1 $1>\mathrm{DP}>\mathrm{TW}$ as shown in Fig. 4-14.

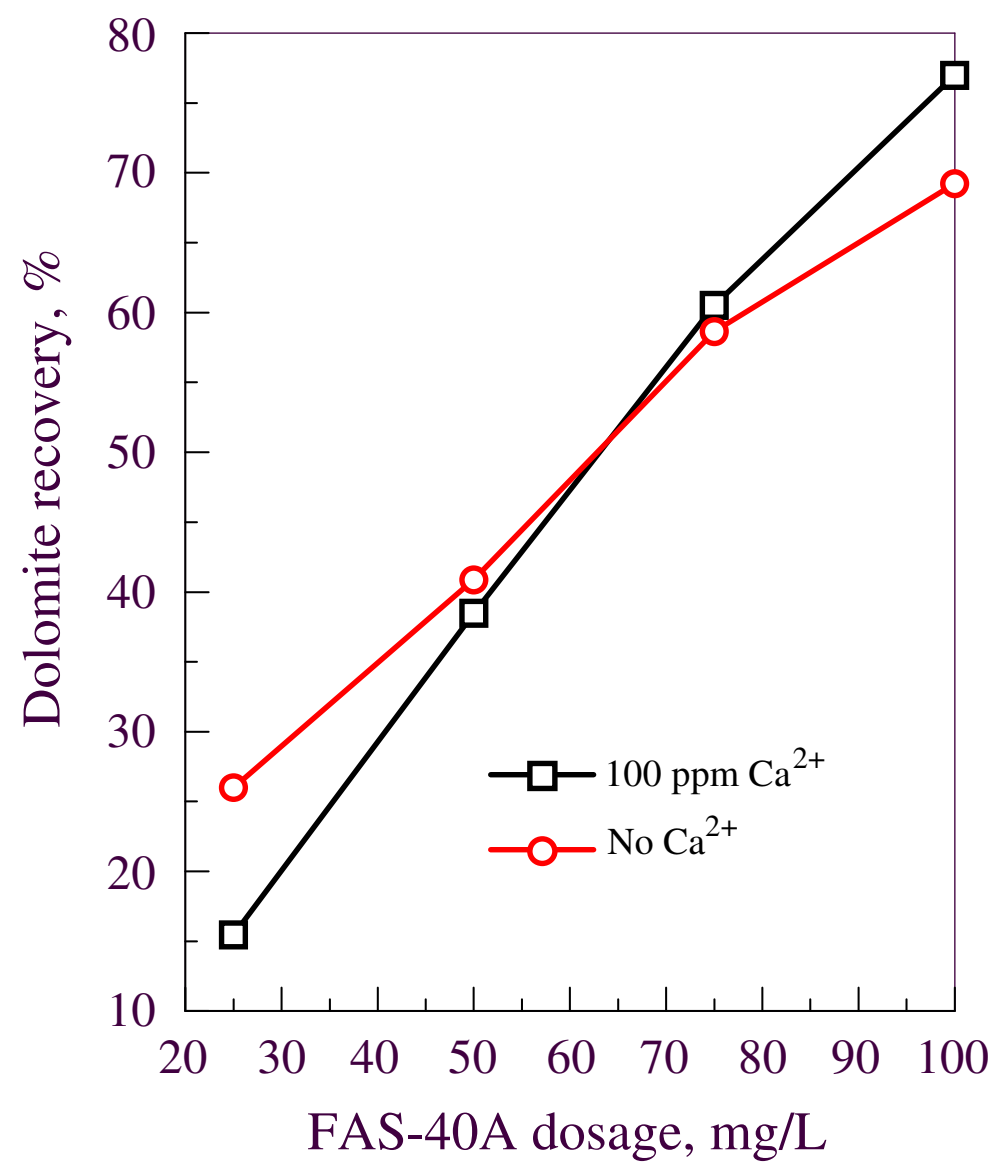

Fig. 4-10 Effect of calcium ions on dolomite flotation using FAS-40A as collector 


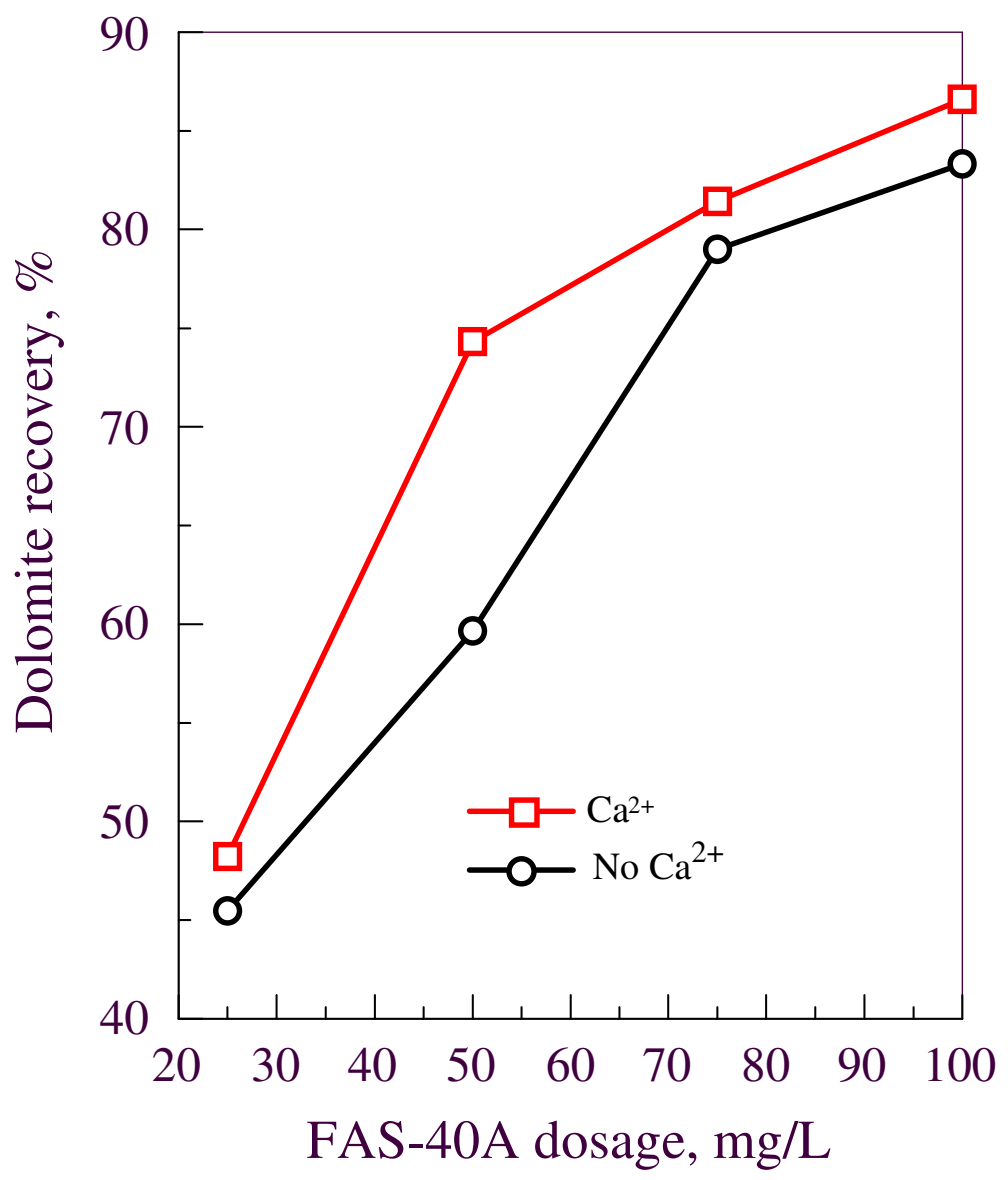

Fig. 4-11 Effect of calcium ions on dolomite flotation using mixture of FAS-40A and $10 \%$ DSS1 as collector 


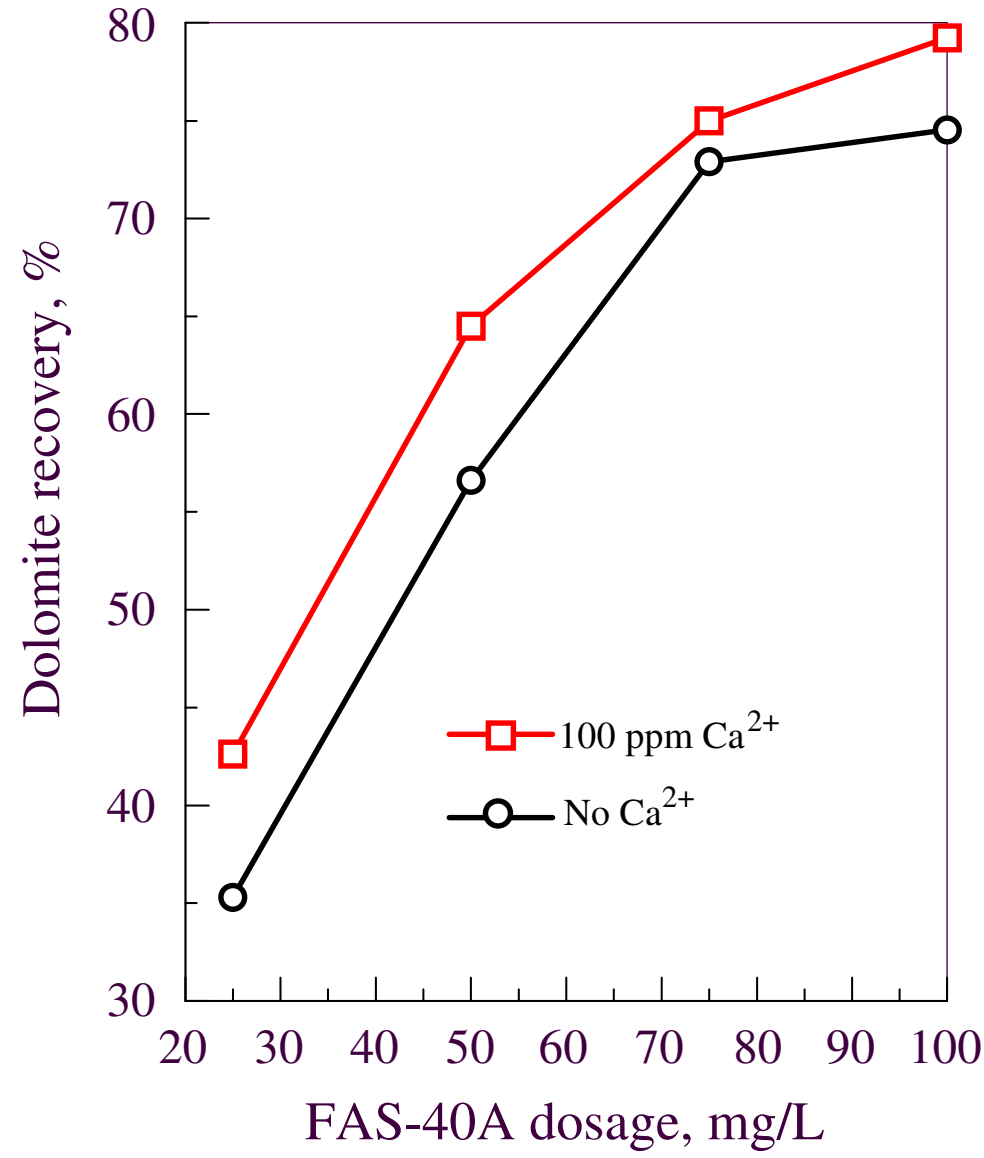

Fig. 4-12 Effect of calcium ions on dolomite flotation using mixture of FAS-40A and $10 \% \mathrm{DP}$ as collector 


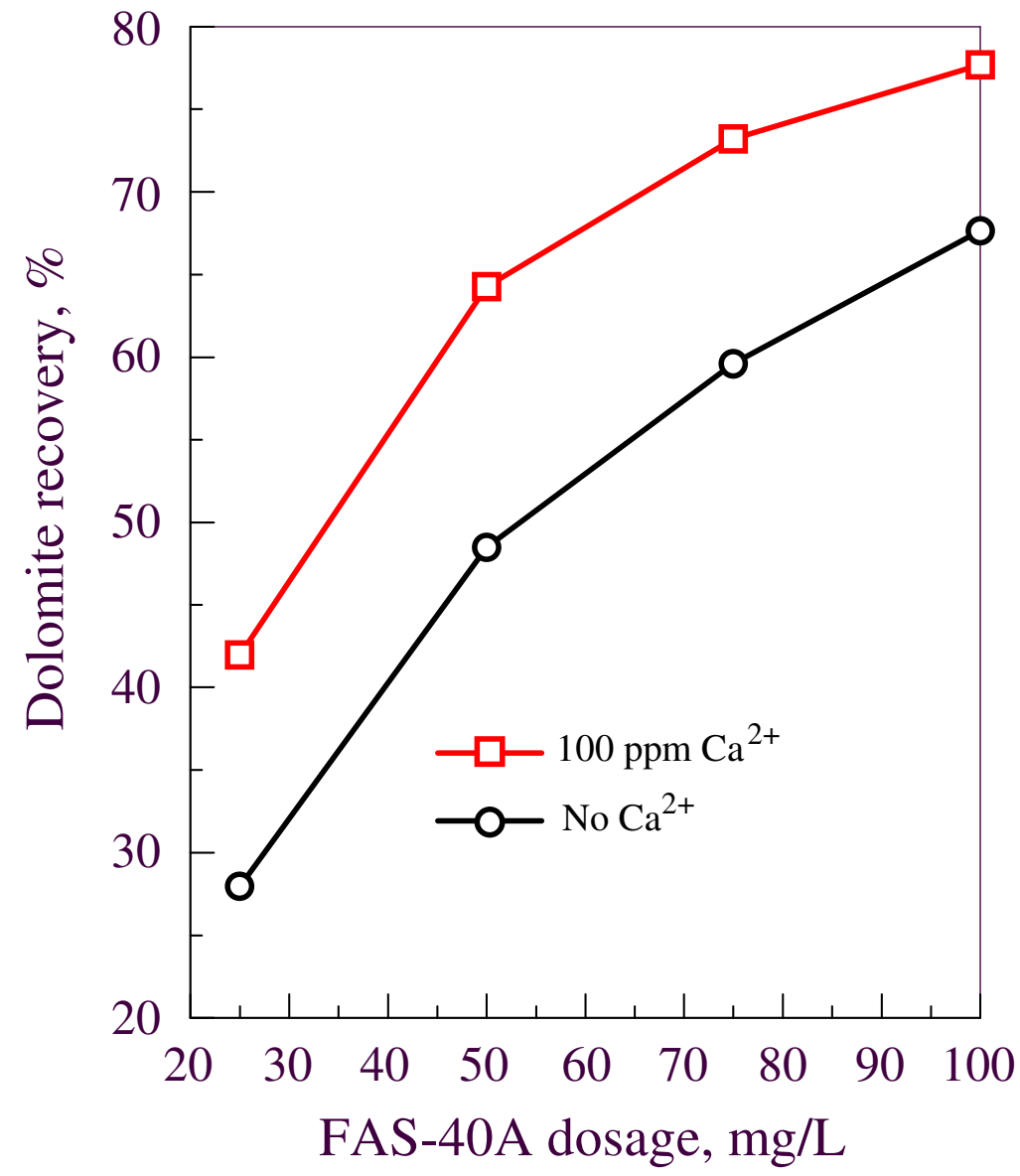

Fig. 4-13 Effect of calcium ions on dolomite flotation using mixture of FAS-40A and $10 \% \mathrm{TW}$ as collector 


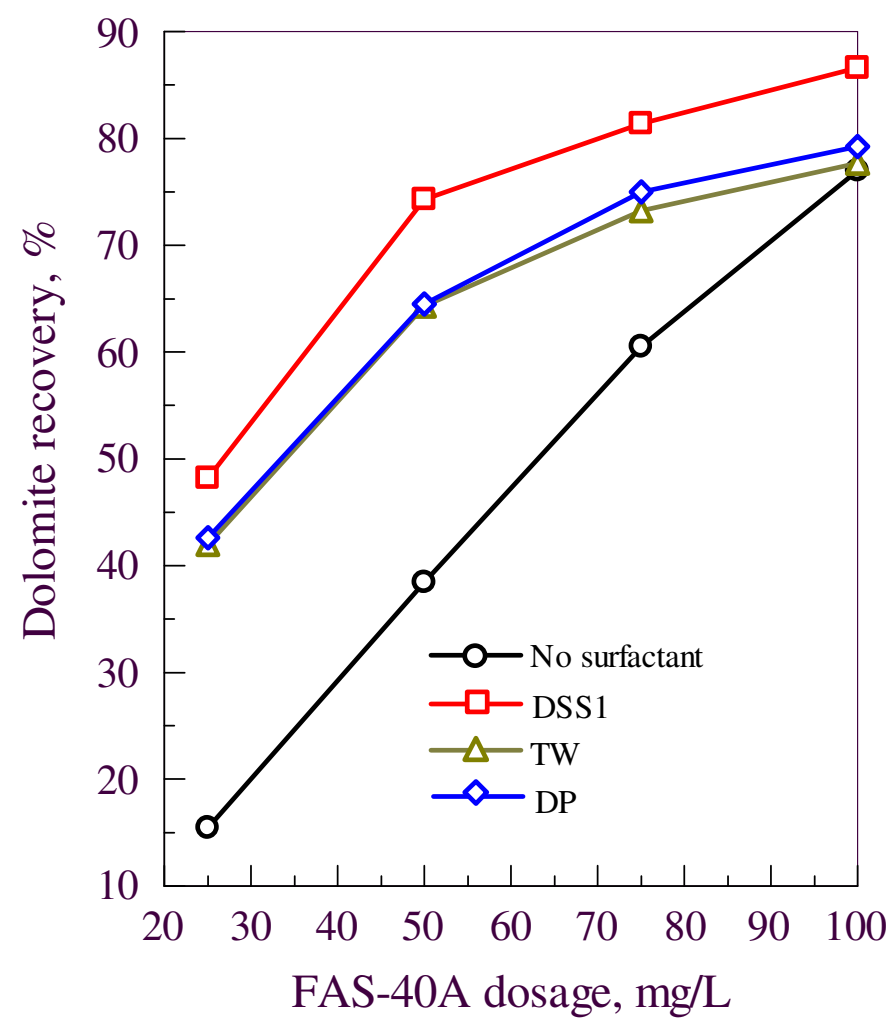

Fig. 4-14 Dolomite flotation recovery as a function of collector dosage at $100 \mathrm{ppm} \mathrm{Ca}^{2+}$ in the presence and absence of surfactants

Sampat Kumar et al. (1971) conducted the fundamental studies on the role of carbon dioxide in calcite flotation. They reported that calcite particles were negatively charged with zeta potential of $-3.89 \times 10^{-5} \mathrm{~cm}$ per sec. per volt per $\mathrm{cm}$ in alkaline $\mathrm{pH}$ 9.1. In the presence of calcium ions in concentrations of $1.33 \times 10^{-3}, 2.66 \times 10^{-3}$ and $6.66 \times 10^{-3}$ moles per liter, the measured zeta potential values were $-4.58 \times 10^{-5},+8.8 \times 10^{-5}$ and $+27.6 \times 10^{-5}$ $\mathrm{cm}$ per sec. per volt per $\mathrm{cm}$. The result shows that the addition of calcium ions changed the zeta potential on the surface of the calcite particles from negatively charged surface to a positive charged surface due to the adsorption or precipitation of cationic calcium ions 
on the calcite particle surfaces. In this study, the Hallimond cell flotation of dolomite was performed in acid solution at $\mathrm{pH}$ 5.5. The results indicate that the addition of calcium ions can improve dolomite flotation. According to the explanations made by other investigators, such improvement was achieved due to the adsorption of negatively charged fatty acid type collector molecules onto the surface of dolomite particles and therefore increased the flotation recovery of dolomite.

In the flotation system of the mixture of dolomite and phosphate or natural dolomitic phosphate ores, there is no report that the flotation of dolomite from phosphate can be improved by addition of calcium ions to the flotation system. This is because that the flotation system of natural minerals is much more complex than that of single pure mineral flotation system under the ideal conditions. In the flotation system of the mixture of dolomite and phosphate or natural phosphate ores, addition of calcium ions also has significant effect on the surface properties of phosphate minerals. Smani at el. (1975) carried out extensive investigation on the influence of calcium ions on apatite. It was reported that without addition of calcium ions, zeta potential was negative for all the apatite particles in the $\mathrm{pH}$ range studied. Addition of calcium ions increased the value of zeta potential, which became zero at the point of zero reversal (PZR). With the increase of calcium ion concentration in the system, the zeta potential became positive. For one sample they studied, the point of zero charge (PZC) was 4.7. The zeta potential was -10 mv at $\mathrm{pH}$ 8.7. When $1.4 \times 10^{-3}$ mole calcium ions was added in the solution, the zeta potential of the apatite particles was zero which was called point of zero reversal (PZR). 
When the calcium ion concentration in the system reached $10^{-2}$ mole, the zeta potential increased to $+10 \mathrm{mv}$. This is probably the reason that the addition of calcium ions could improve the flotation recovery of single pure mineral. However the findings do not apply to the flotation system of the mixture of dolomite and phosphate or natural dolomitic phosphate ores as illustrated in studies conducted by other investigators, as well as in this study (see section 4.3).

\subsubsection{Effect of Particle Size on Dolomite Flotation}

The pure dolomite sample was split into three size fractions, $-355+250 \mu \mathrm{m}(-45+60$ mesh), $-250+150 \mu \mathrm{m}(-60+100$ mesh) and $-150+75 \mu \mathrm{m}(-100+200 \mathrm{mesh})$ for investigating the effect of selected surfactants on dolomite flotation. Each size fraction was used as flotation feed using FAS-40A alone or the mixture of FAS-40A and selected surfactants as collector. The results of dolomite flotation as a function of surfactant dosages for different size fraction are given in Figs. 4-15, 4-16, 4-17 and 4-18. The test results show that finer size fraction had higher dolomite flotation recovery than coarser size fraction using FAS-40A as collector with or without surfactants. To achieve the same recovery, less reagent dosage was needed for fine size feed. This is because small particles are lighter in mass than large particles, and less adhesive is needed to attach the particles on the bubble surface. According to the mathematical equation, the volume of the particle is proportional to its cube of radius. The mass of the particle equals the product of its volume and density. The average mass of $-355+250 \mu \mathrm{m}(-45+60$ mesh) particles is about 
3.5 times of $-250+150 \mu \mathrm{m}(-60+100 \mathrm{mesh})$ particles and about 20 times of $-100+200$ mesh particles. It is clear that more reagent is required to adhere larger particles to the surface of air bubbles.

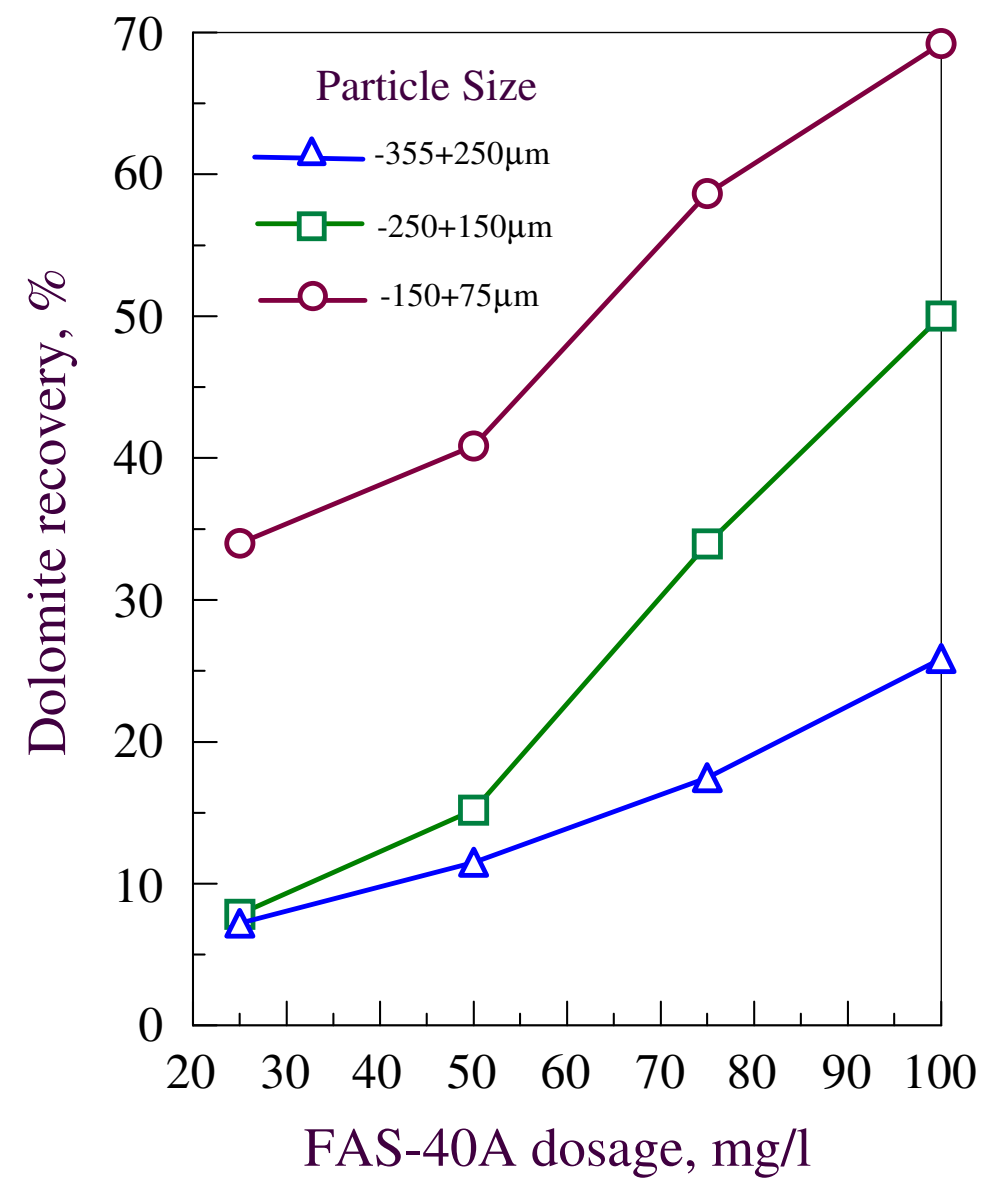

Fig. 4-15 Dolomite flotation recovery as a function of FAS-40A dosage for different size fractions 


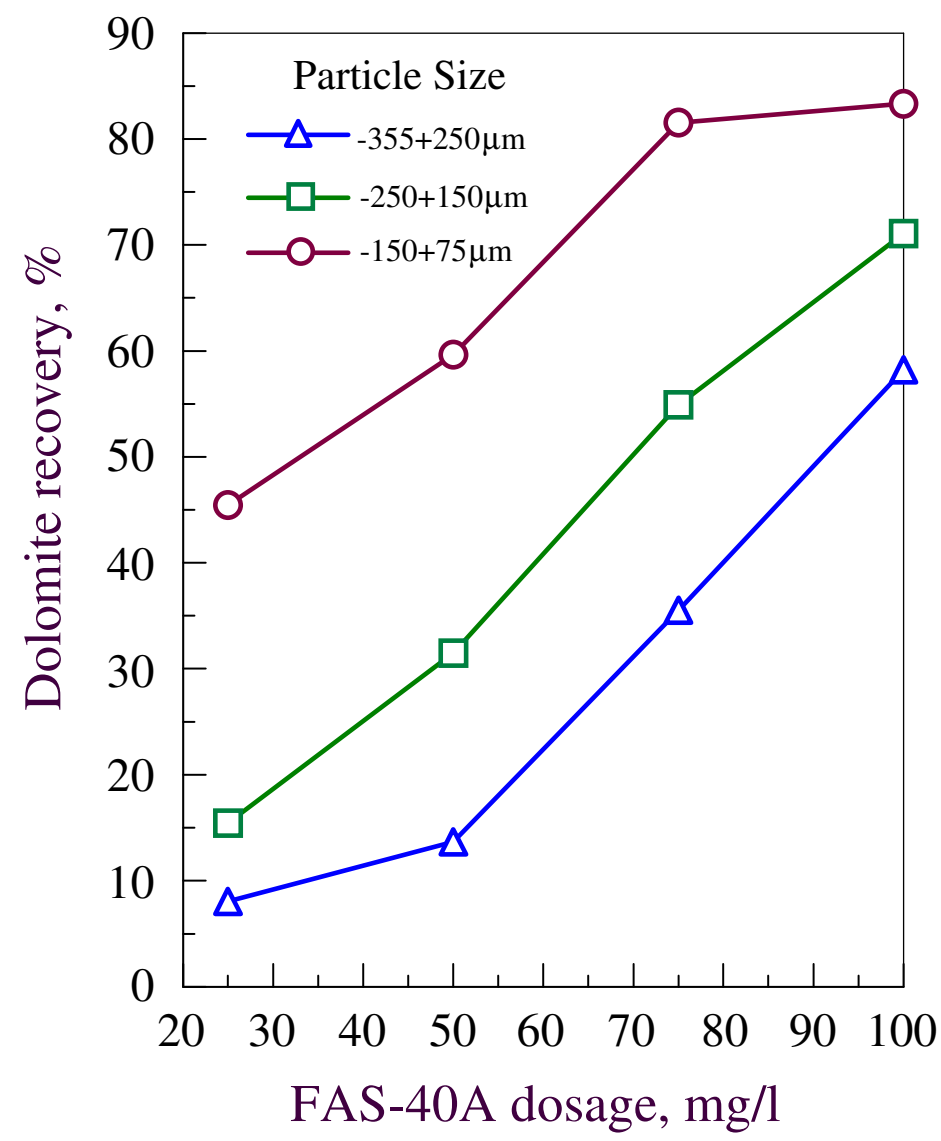

Fig. 4-16 Dolomite flotation recovery as a function of FAS-40A and 10\% DSS1 dosage for different size fractions 


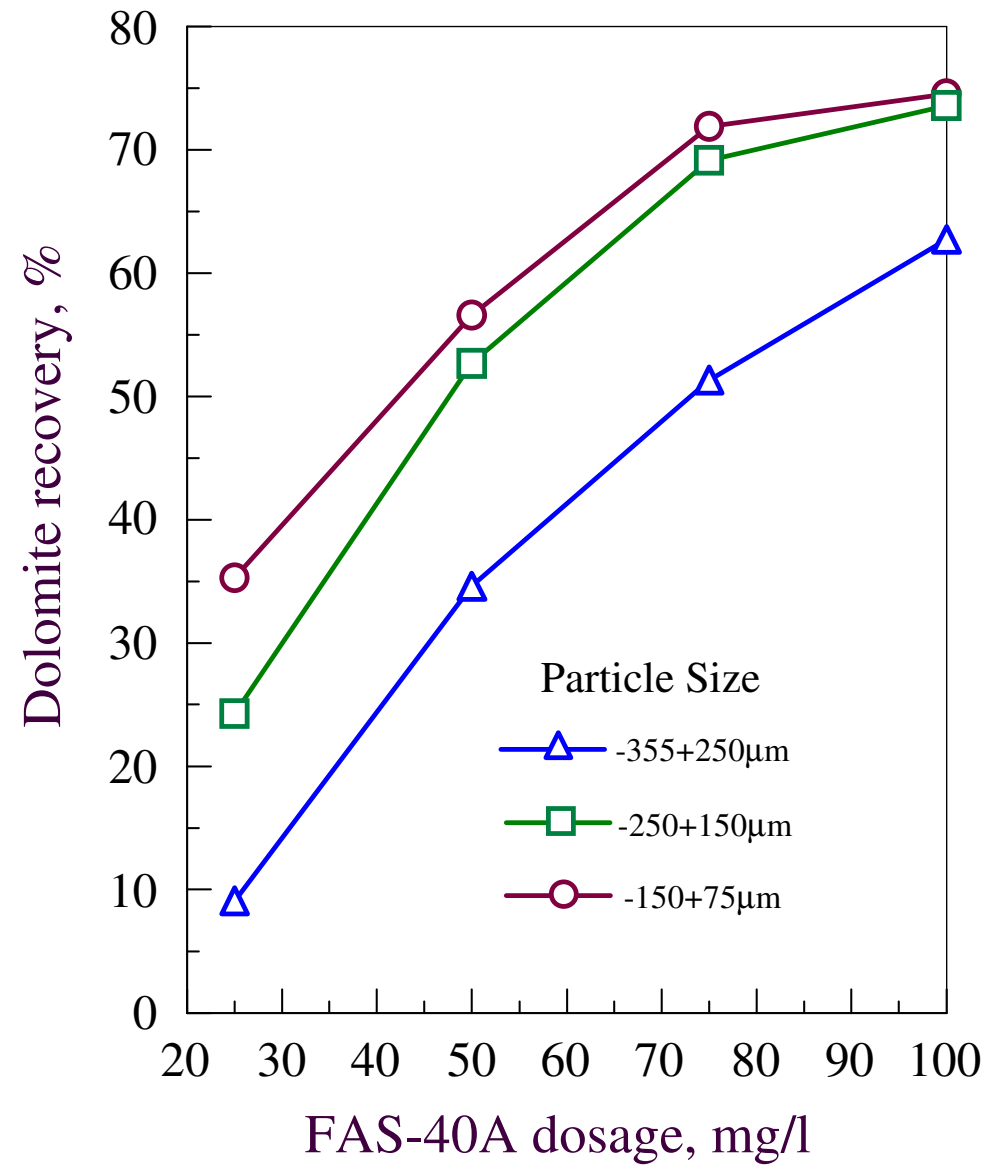

Fig. 4-17 Dolomite flotation recovery as a function of FAS-40A and 10\% DP dosage for different size fractions 


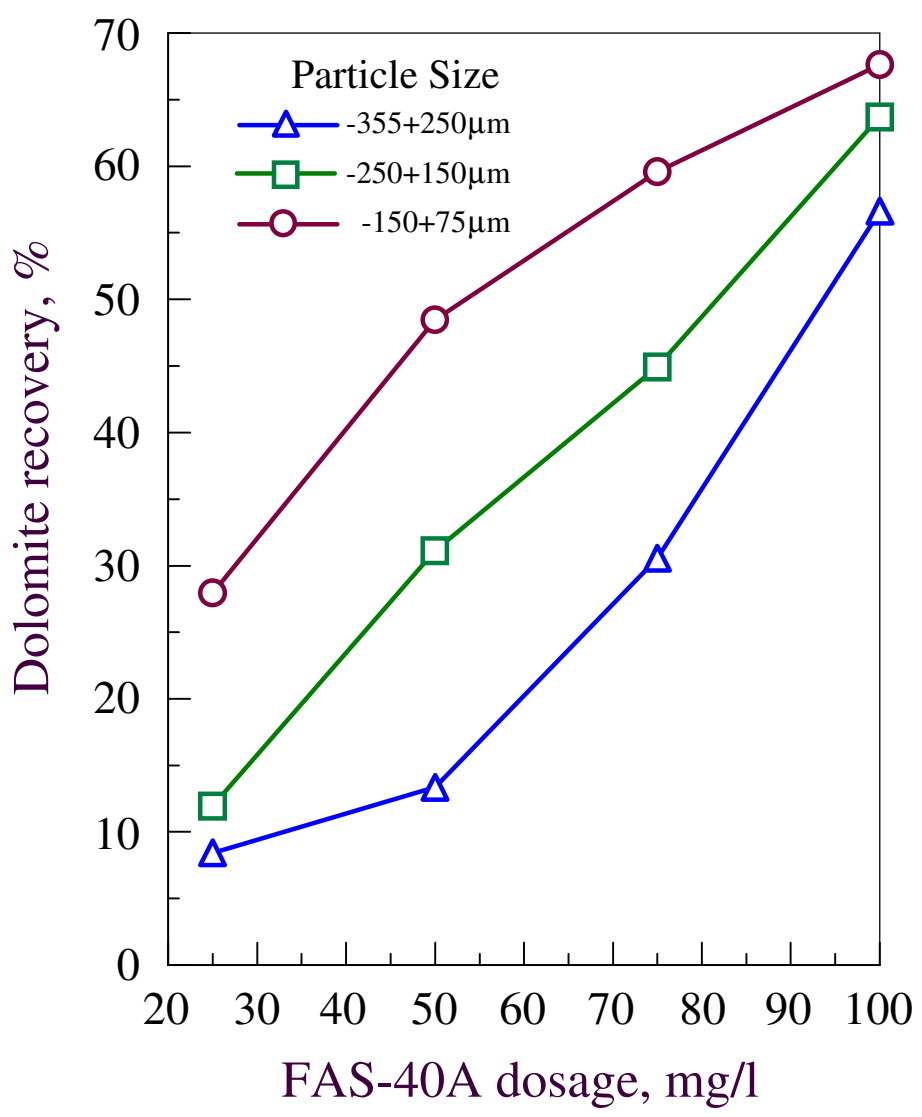

Fig. 4-18 Dolomite flotation recovery as a function of FAS-40A dosage in presence of $10 \% \mathrm{TW}$ for different size fractions

The comparisons of the results of dolomite flotation recovery on each size fraction using FAS-40A and its mixture with selected surfactants are plotted in Figs. 4-19, 4-20 and 4-21. Those figures demonstrate that DP can enhance the flotation performance of larger particles such as $-355+250 \mu \mathrm{m}(-45+60 \mathrm{mesh})$ and $-250+150 \mu \mathrm{m} \quad(-60+100 \mathrm{mesh})$ fractions and DSS1 could improve the flotation results of finer fraction such as $-150+75 \mu \mathrm{m}(-100+200 \mathrm{mesh})$. 


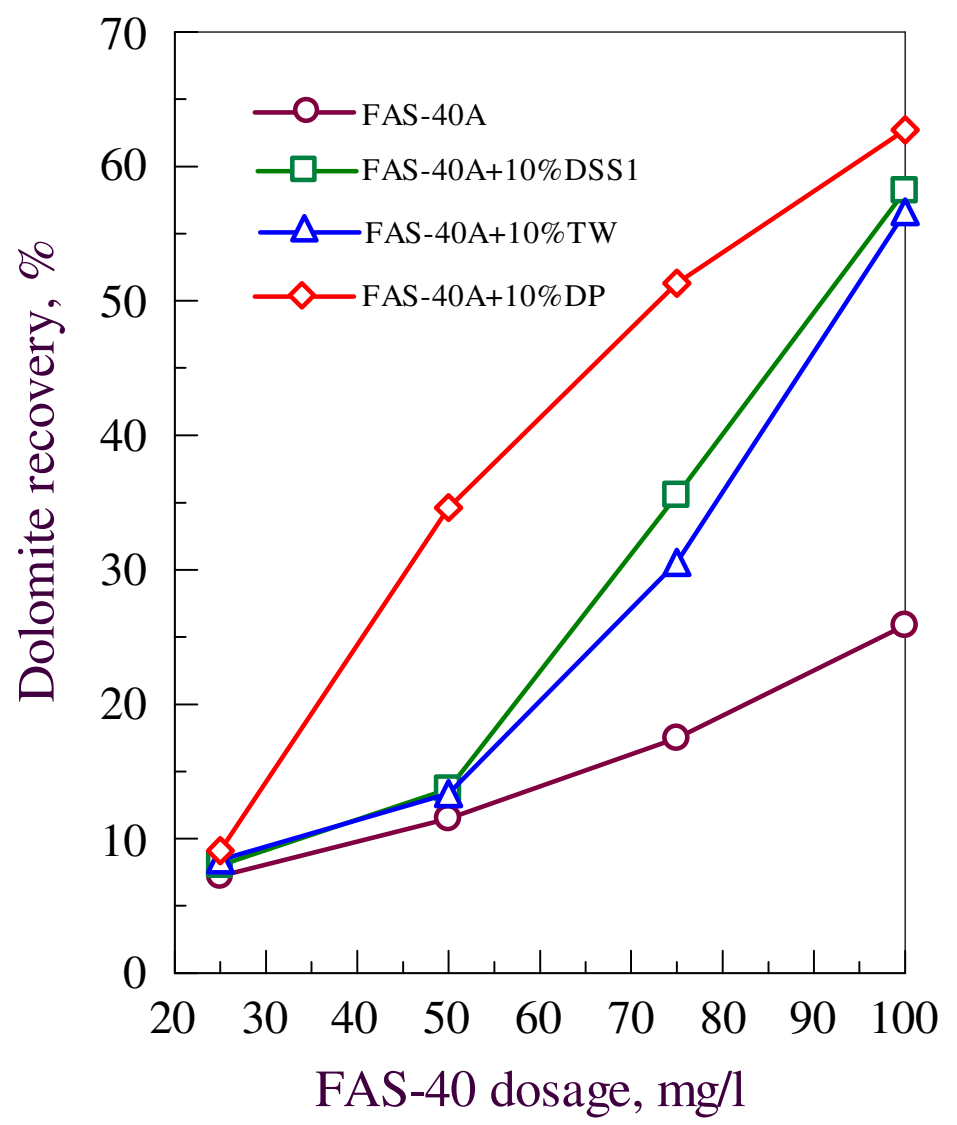

Fig. 4-19 Effect of mixture of FAS-40A and selected surfactants on flotation of $-355+250 \mu \mathrm{m}(-45+60$ mesh $)$ feed 


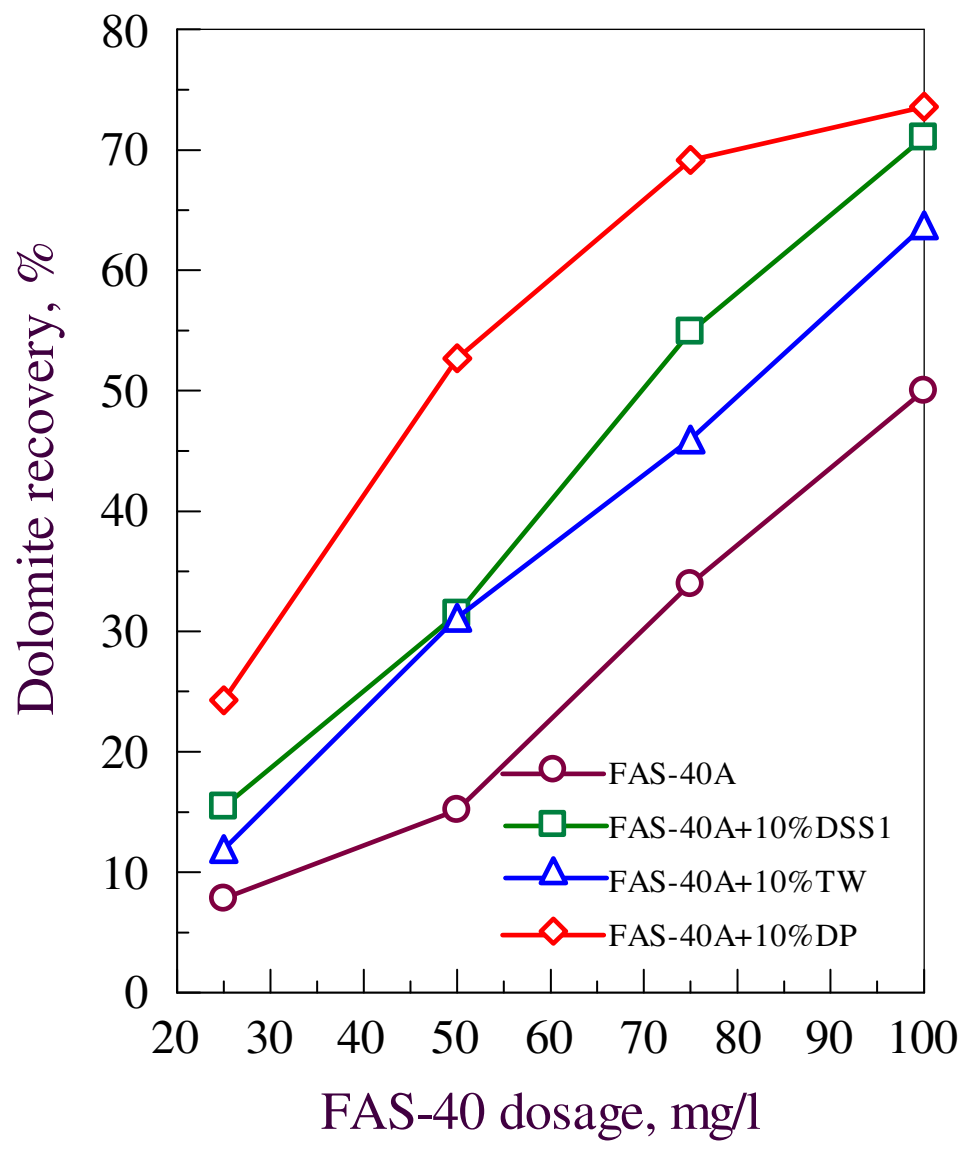

Fig. 4-20 Effect of mixture of FAS-40A and selected surfactants on flotation of $-250+150 \mu \mathrm{m}(-60+100$ mesh) feed 


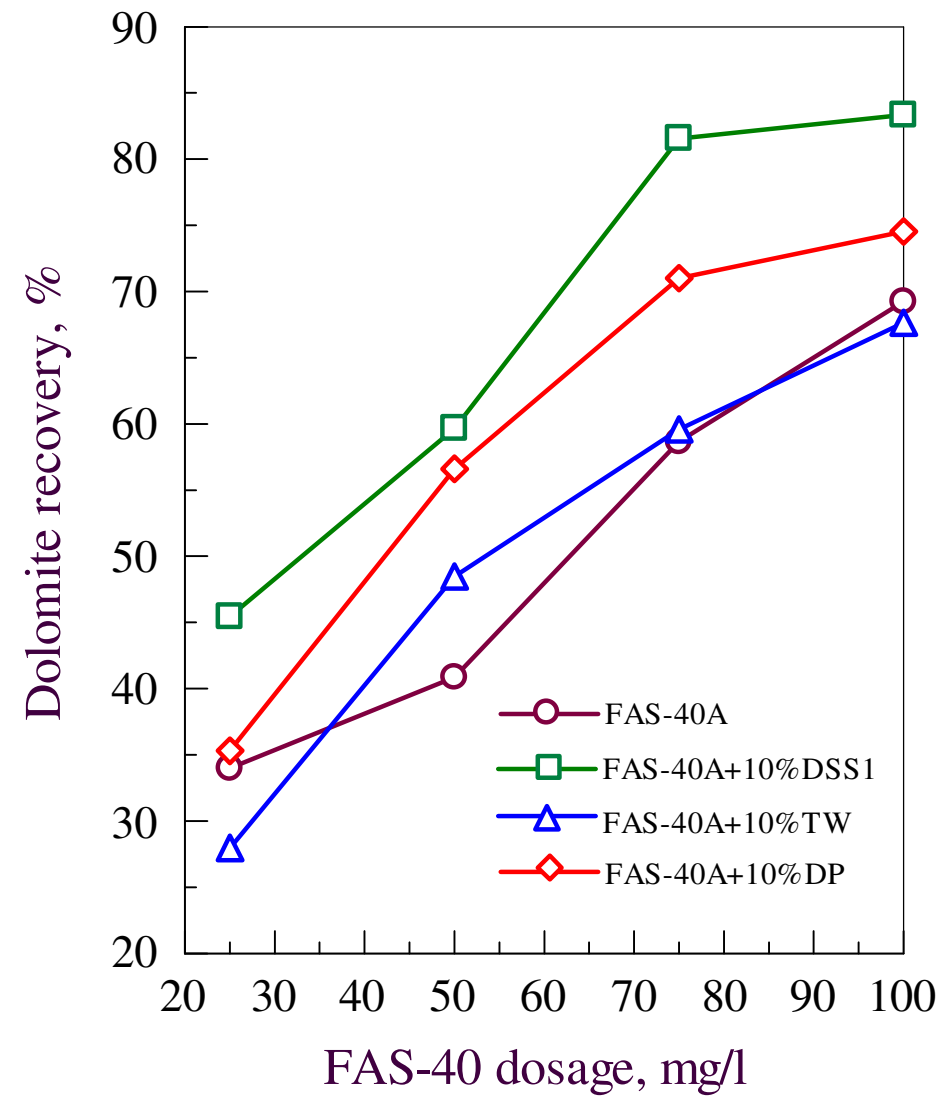

Fig. 4-21 Effect of mixture of FAS-40A and selected surfactants on flotation of

$$
-150+75 \mu \mathrm{m}(-100+200 \text { mesh) feed }
$$

\subsubsection{Effect of Slimes}

Minus $20 \mu \mathrm{m}$ fine dolomite particles were prepared and added to flotation slurry to evaluate the effect of fine slimes on dolomite flotation using the mixture of FAS-40A and selected surfactants as collector. The test results are plotted in Figs. 4-22 to 4-25. Those figures show that the dolomite flotation recovery decreased with the increase of the slime content in the dolomite flotation slurry. It is well known that the fine particles consume 
much more reagents due to their large specific surface area. Some of those slime fines may precipitate onto the surface of the large dolomite particles and report to float, but most of them remain in the slurry.

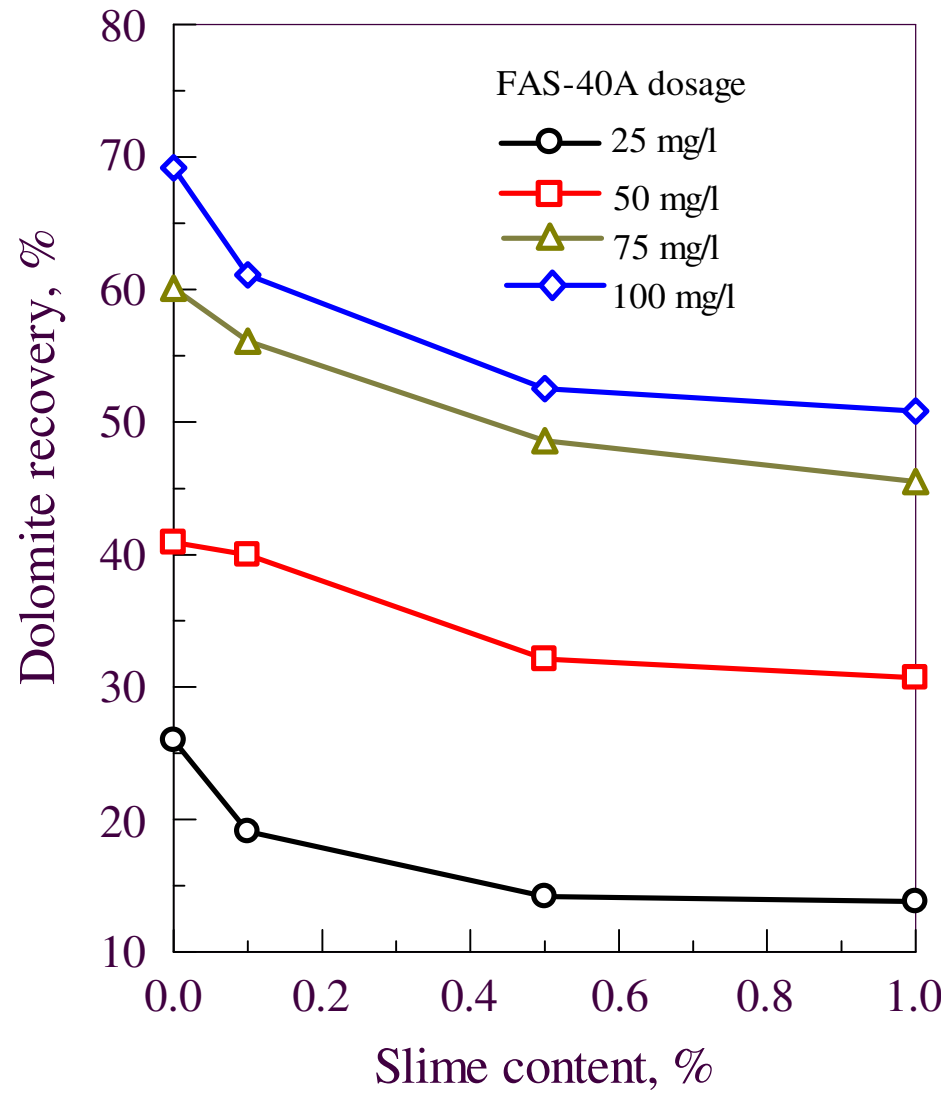

Fig. 4-22 Dolomite flotation recovery as a function of slime contents at different

FAS-40A dosages 


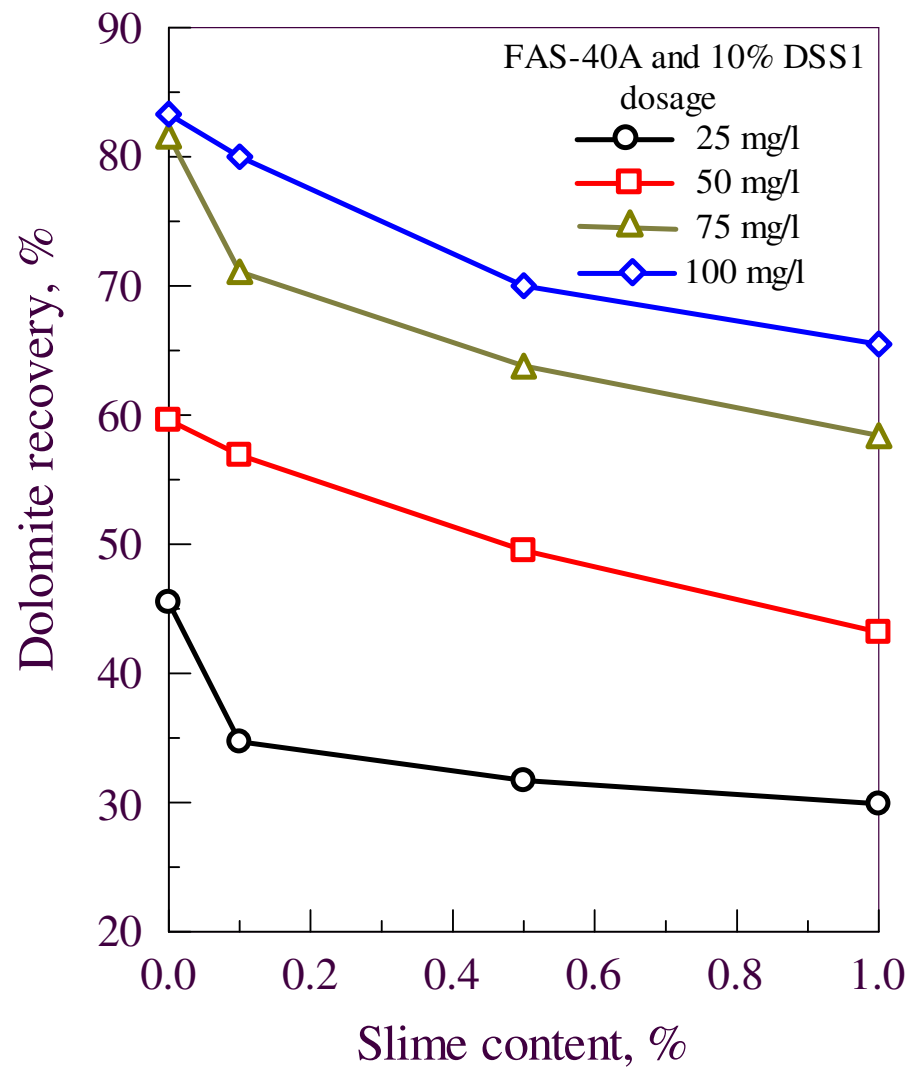

Fig. 4-23 Dolomite flotation recovery as a function of slime contents at different dosages of the mixture of FAS-40A and 10\% DSS1 


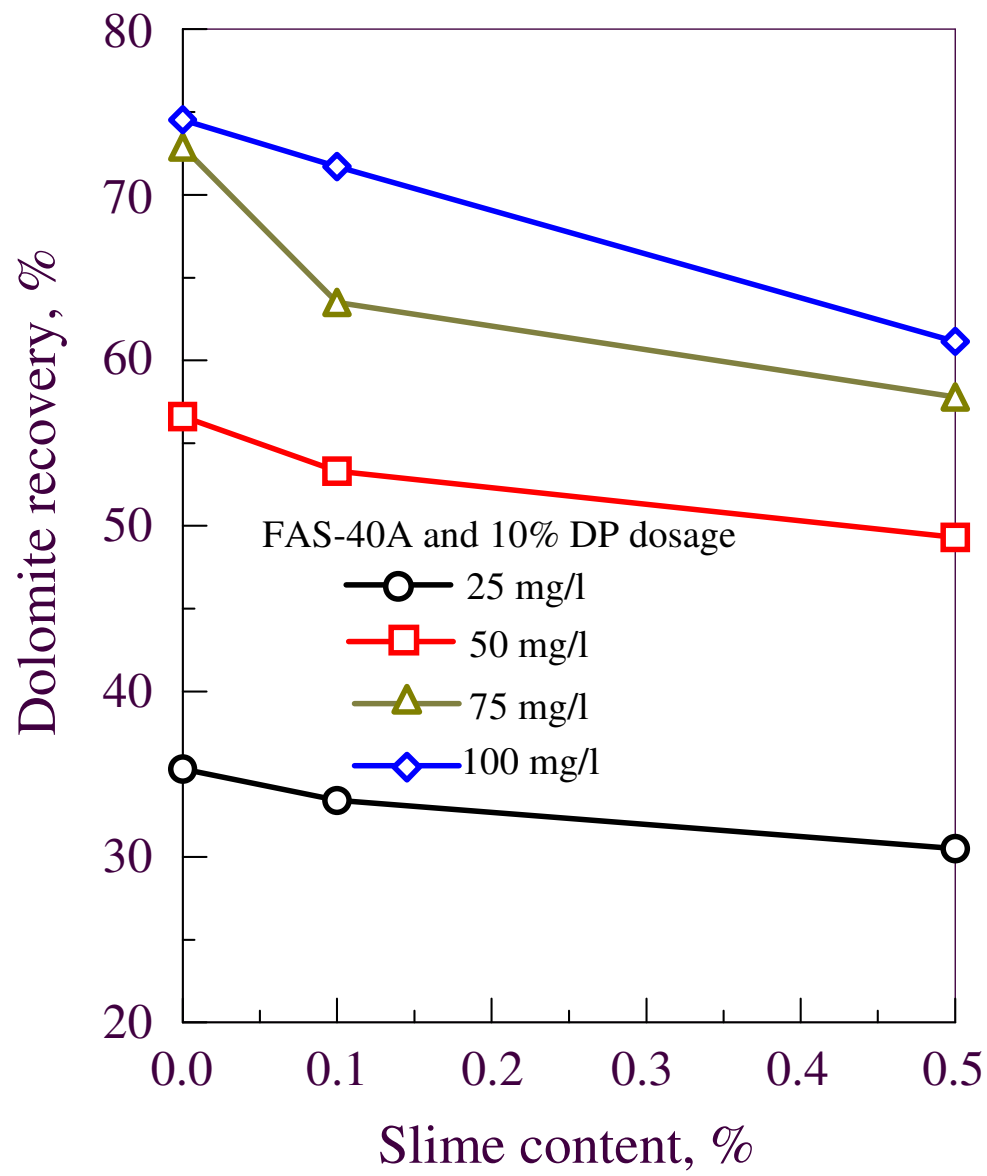

Fig. 4-24 Dolomite flotation recovery as a function of slime contents at different dosage of the mixture of FAS-40A and $10 \%$ DP 


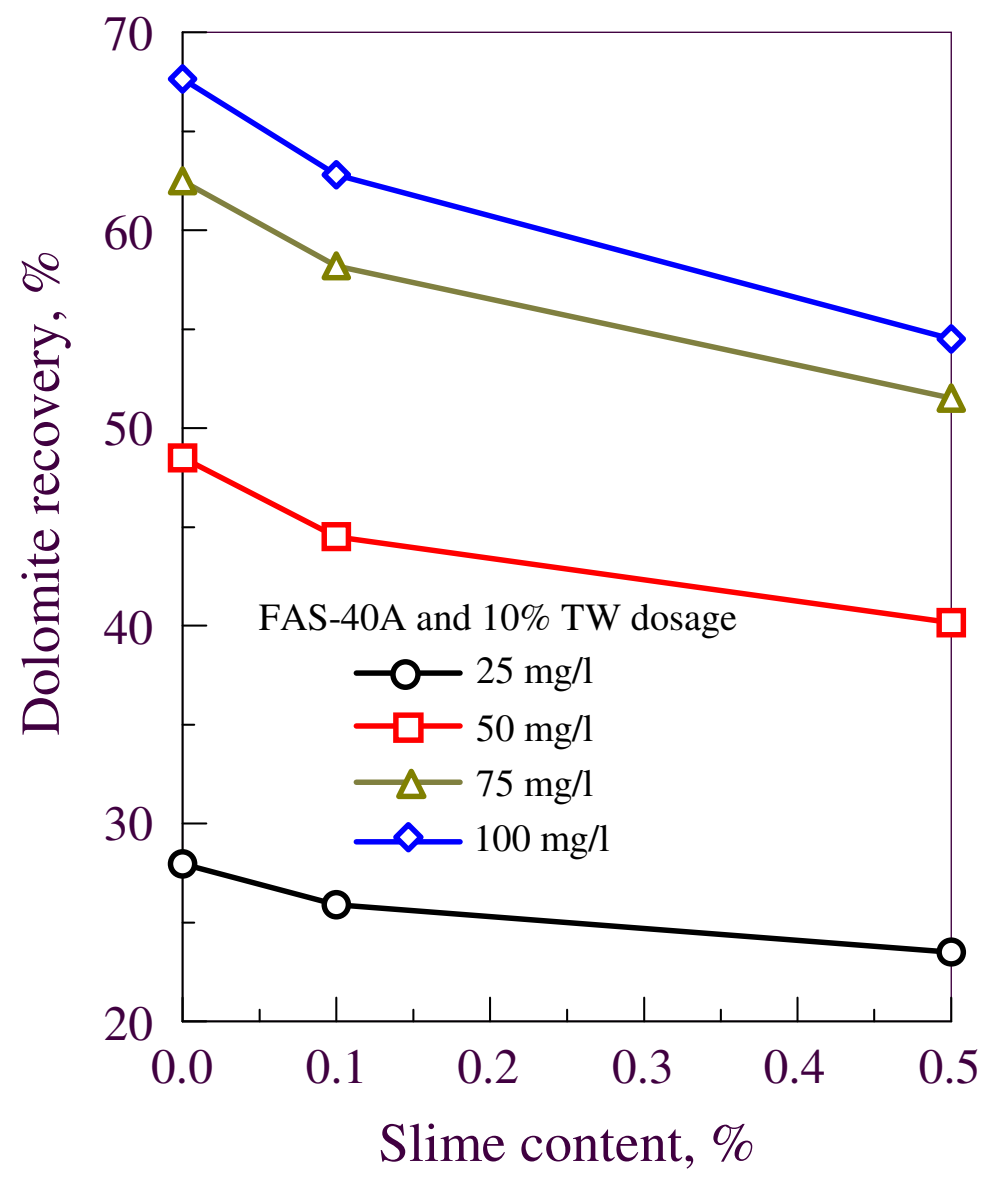

Fig. 4-25 Dolomite flotation recovery as a function of slime contents at different dosages of the mixture of FAS-40A and $10 \%$ TW

For comparison purpose, the effects of slime content on dolomite flotation at the collector dosages of 50 and 75 ppm FAS-40A with $10 \%$ of different surfactants are plotted in Figs. 4-26 and 4-27 respectively. It can be seen that the dolomite recovery decreases with the increase of slime content. However, application of $10 \%$ DSS1 in collector can achieve higher dolomite flotation recovery compared to the other two surfactants and no surfactant. 


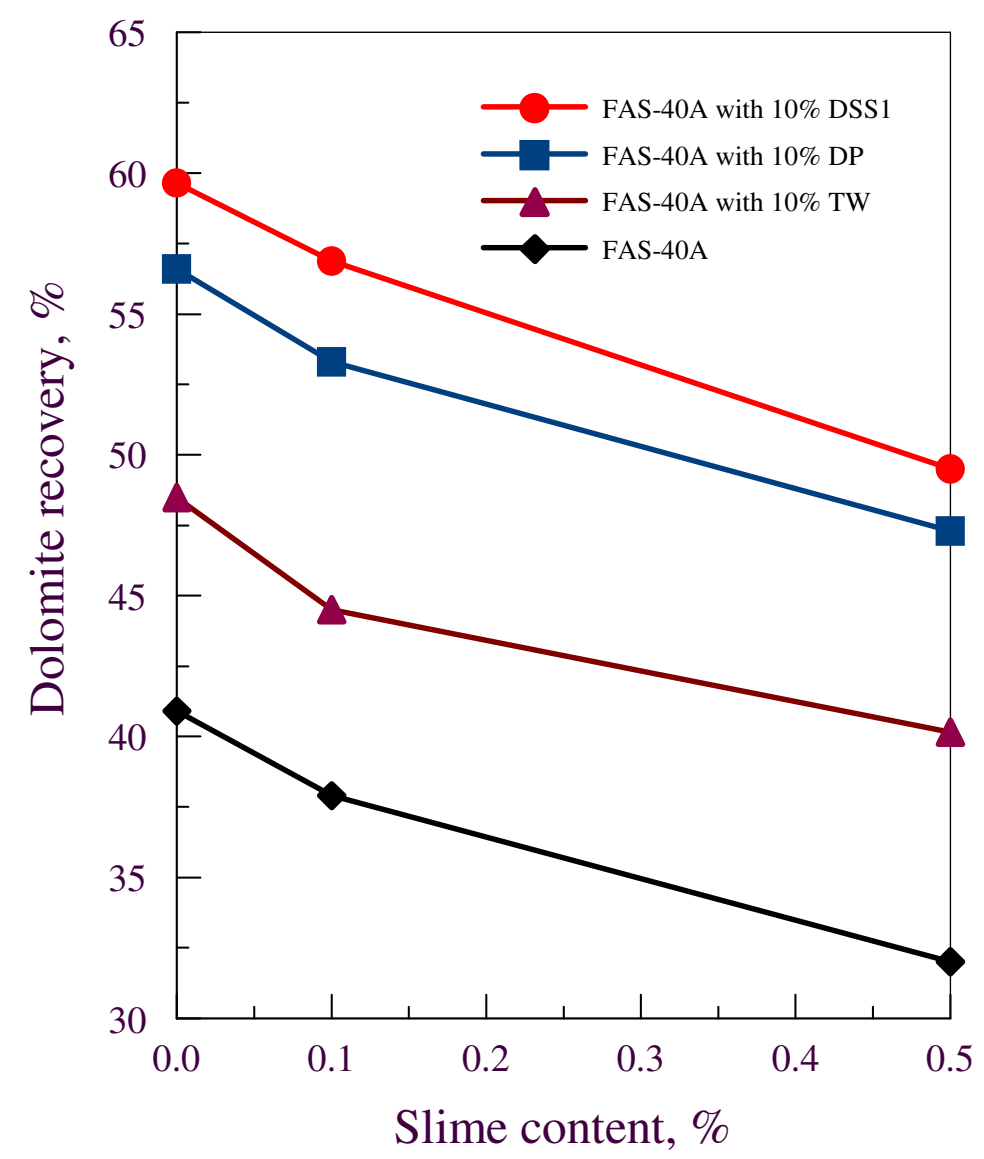

Fig. 4-26 Dolomite flotation recovery as a function of slime content at collector dosage of $50 \mathrm{ppm}$ FAS-40A with $10 \%$ selected surfactant 


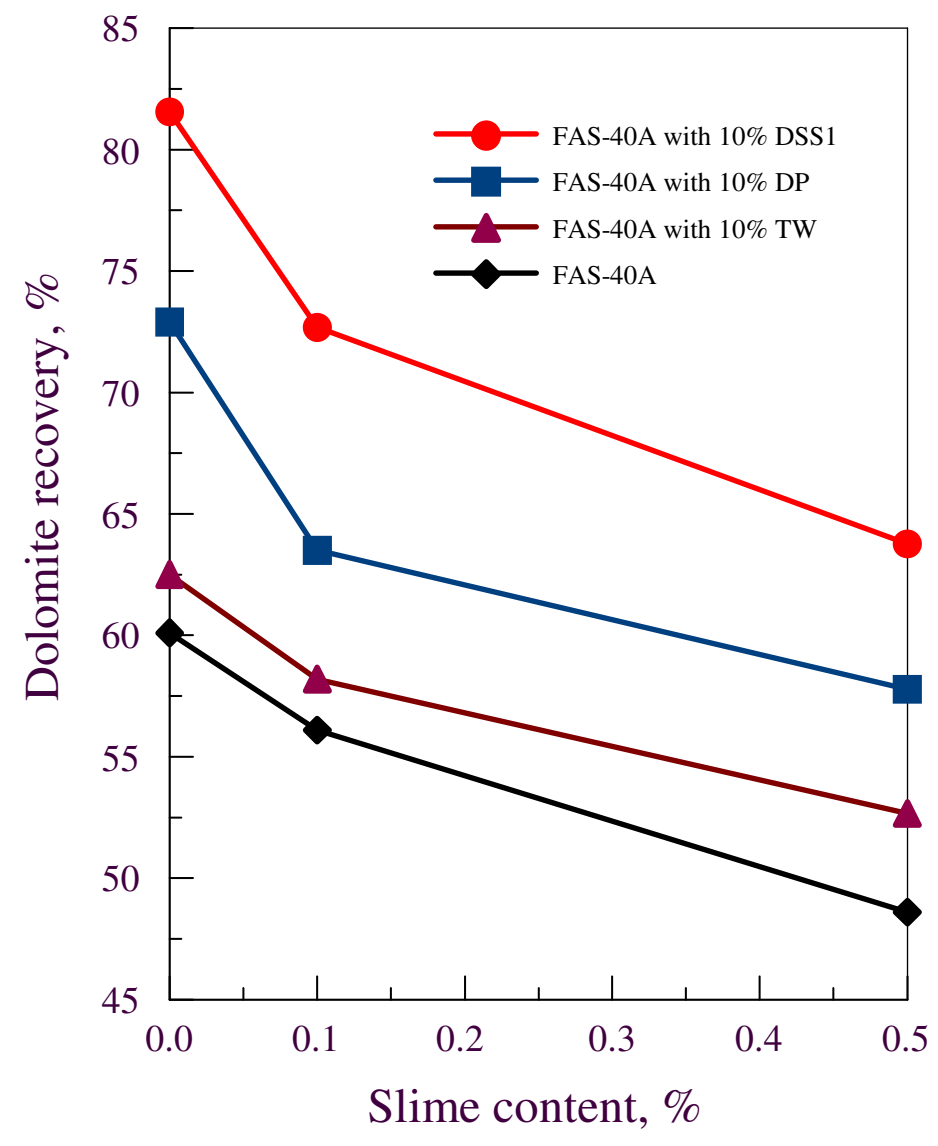

Fig. 4-27 Dolomite flotation recovery as a function of slime content at collector dosage of 75 ppm FAS-40A with $10 \%$ selected surfactant 


\subsection{Batch Cell Flotation of Natural Dolomitic Phospahte Ores}

Batch flotation experiments were conducted on natural Florida dolomitic phosphate pebble samples identified as sample $\mathrm{H}$ and sample $\mathrm{L}$. Both samples were collected from IMC-Phosphate Four Corner Mine, Florida. Sample H has high MgO content, about 3.3\%. The $\mathrm{MgO}$ in sample $\mathrm{L}$ was much lower, about $1.5 \%$. The batch flotation experiments were conducted to evaluate the effects of different type of collectors, addition of selected surfactants, flotation $\mathrm{pH}$ and so on.

\subsection{1 pH Effect on Dolomite Flotation}

As mentioned in paragraph 2.5.1, Xiao and colleagues (1987) investigated the flotation behavior of dolomite and francolite at different oleate concentrations and different $\mathrm{pH}$ with the test results plotted in Fig. 2-1. The figure indicates that selective flotation of francolite can be achieved above $\mathrm{pH} 9.0$ and dolomite below $\mathrm{pH}$ 5.0. But there was no selective separation when the mixture sample or natural sample was used. They claimed that the loss of selectivity of separation of dolomite from francolite could be attributed to the alteration of the surface properties of both minerals by the dissolved mineral species.

Although some researches have been conducted to understand the flotation behavior of both dolomite and phosphate with pure mineral samples, little work has been done so far on natural dolomitic phosphate samples due to the extreme complexity of the 
components in its flotation system. In this study, natural Florida high dolomitic phosphate sample was used for the test work to evaluate the effect of $\mathrm{pH}$ values on the flotation performance of separating dolomite from phosphate. Fatty acid type collector, FAS-40A, was used as collector, phosphoric acid and sodium hydroxide as $\mathrm{pH}$ modifier. The collector dosage was fixed at $2.5 \mathrm{~kg} / \mathrm{t}$ of feed for each run. Phosphoric acid is applied to adjust acidic $\mathrm{pH}$ and sodium hydroxide to adjust alkaline $\mathrm{pH}$. The $\mathrm{MgO}$ and $\mathrm{P}_{2} \mathrm{O}_{5}$ grade in the float of dolomite flotation as a function of $\mathrm{pH}$ is given in Fig. 4-28. It can be seen that, to some extent, one curve is the mirror opposite of the other one, indicating that higher $\mathrm{MgO}$ content corresponds to lower $\mathrm{P}_{2} \mathrm{O}_{5}$ grade and higher $\mathrm{P}_{2} \mathrm{O}_{5}$ grade corresponds to lower $\mathrm{MgO}$ content. Below $\mathrm{pH} 4.5, \mathrm{MgO}$ grade goes up and $\mathrm{P}_{2} \mathrm{O}_{5}$ goes down with the increase of $\mathrm{pH}$. Between $\mathrm{pH} 4.5$ and 6, there is a sharp increase in $\mathrm{P}_{2} \mathrm{O}_{5}$ grade and a sharp decrease in $\mathrm{MgO}$ grade. After $\mathrm{pH}$ 6, the changes in both $\mathrm{MgO}$ and $\mathrm{P}_{2} \mathrm{O}_{5}$ grade level off. Higher $\mathrm{P}_{2} \mathrm{O}_{5}$ and lower $\mathrm{MgO}$ grade in the float indicate poor separation selectivity. At low $\mathrm{pH}$, bubbles are brittle and easily coalescent. The froth layer was not thick enough to allow a secondary concentration or cleaning process, which resulted in more phosphate entering into float. In order to raise the $\mathrm{pH}$, only sodium hydroxide was used, and there was no depressant applied to inhibit the phosphate flotation. At higher $\mathrm{pH}(>6)$, it can be considered as phosphate flotation rather than dolomite flotation, however, dolomite was entrapped into float. Therefore, the $\mathrm{MgO}$ grade is much lower than $\mathrm{P}_{2} \mathrm{O}_{5}$ grade in the float. 


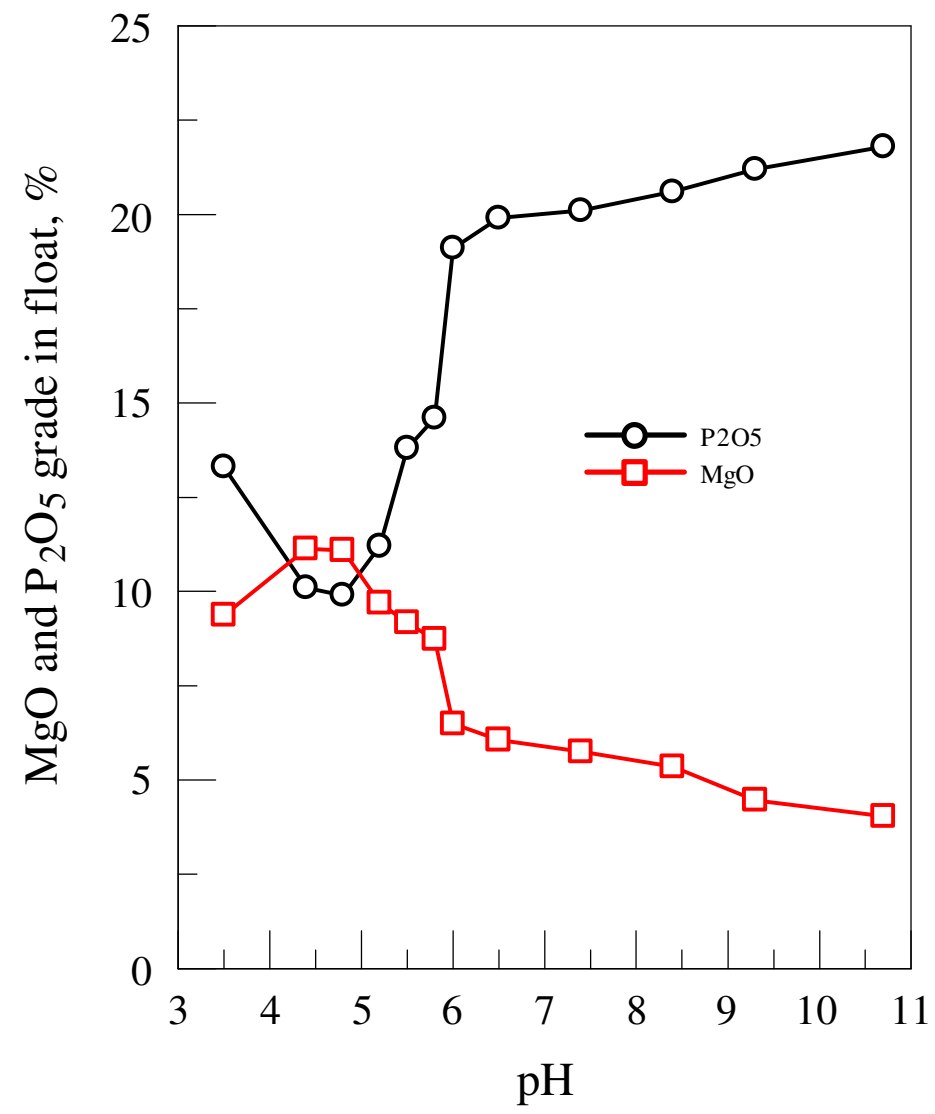

Fig. 4-28 $\mathrm{MgO}$ and $\mathrm{P}_{2} \mathrm{O}_{5}$ grade in dolomite flotation float as a function of flotation $\mathrm{pH}$

Fig. 4-29 presents the $\mathrm{MgO}$ and $\mathrm{P}_{2} \mathrm{O}_{5}$ recoveries in the float and separation index (SI) of flotation process at different $\mathrm{pH}$ values. This figure is quite different from Fig. 2.1 reported by Xiao and coworkers for pure dolomite flotation. In this figure, it can be seen that flotation recoveries of both dolomite and phosphate in the float went up with the increase of $\mathrm{pH}$ value with the $\mathrm{MgO}$ recovery higher than $\mathrm{P}_{2} \mathrm{O}_{5}$ recovery. At $\mathrm{pH} 3.5$, both dolomite and phosphate was depressed and their recoveries were quite low. From $\mathrm{pH} 3.5$ to 5.4 , the $\mathrm{MgO}$ recovery increases very sharply and the increasing rate is much retarded after $\mathrm{pH} 5.4$, while there is only slow increase in $\mathrm{P}_{2} \mathrm{O}_{5}$ recovery. After $\mathrm{pH} 5.4$, the $\mathrm{MgO}$ 
recovery decreases. At about $\mathrm{pH} 6$, there is a sharp increase in both $\mathrm{MgO}$ and $\mathrm{P}_{2} \mathrm{O}_{5}$. This is because there was no phosphoric acid used in order to obtain neutral and alkaline $\mathrm{pH}$ after $\mathrm{pH}$ 6. As mentioned previously, phosphoric acid functions as both $\mathrm{pH}$ modifier and phosphate depressant in dolomite flotation. Without a depressant, much more phosphate was floated with very poor selectivity and dolomite also went with phosphate. This tendency continues from neutral $\mathrm{pH}$ to complete alkaline $\mathrm{pH}$. The objective of dolomite flotation process is to reject as much dolomite in the float as possible while to recover as much phosphate in the sink as possible. The big difference between $\mathrm{MgO}$ and $\mathrm{P}_{2} \mathrm{O}_{5}$ recovery in the float and sink indicates better separation performance. From Fig. 4-29, it can be observed that the biggest difference occurs in $\mathrm{pH}$ range of 4.5 to 5.8. Separation selectivity index curve in Fig. 4-29 shows that best separation can be achieved about pH 5.0 . 


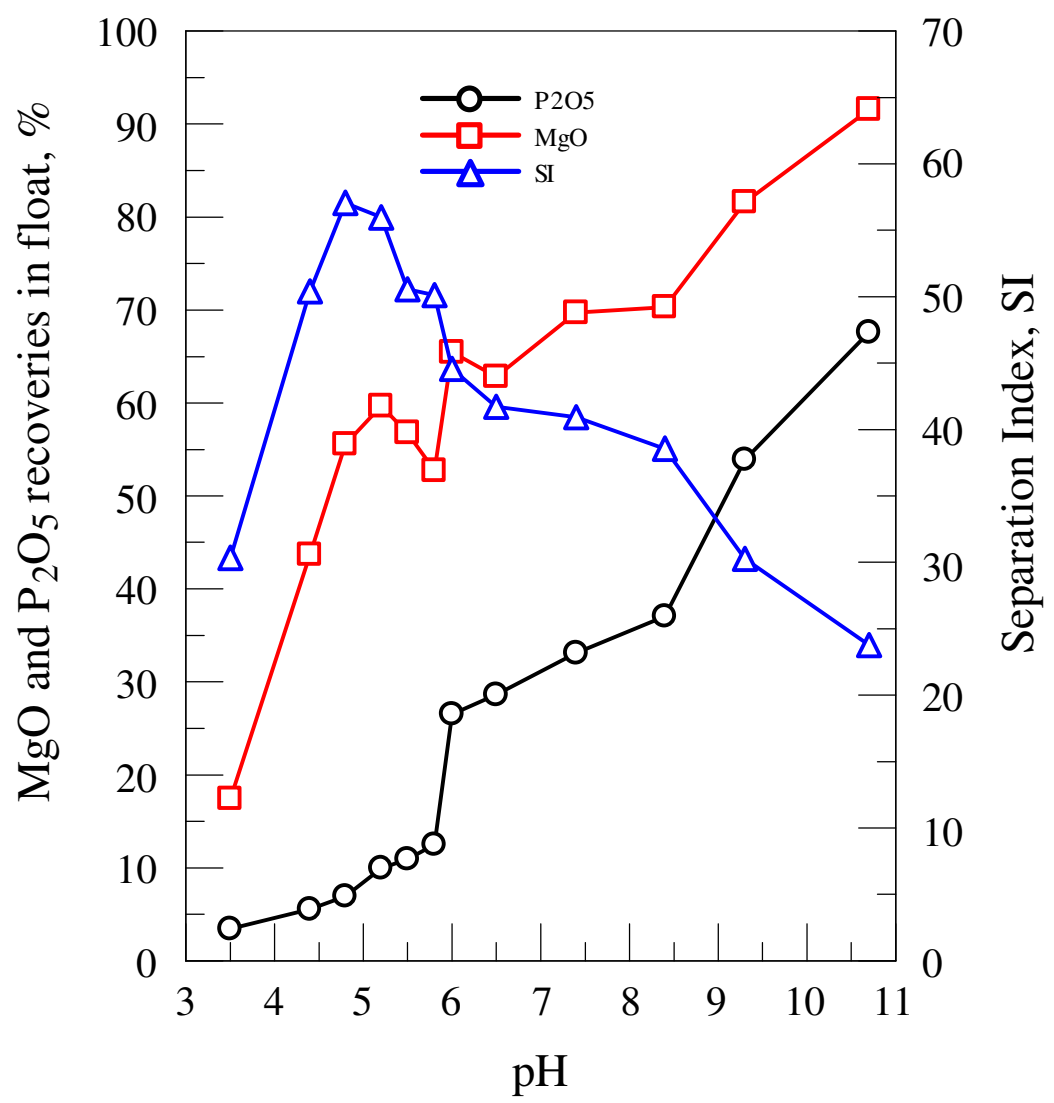

Fig. 4-29 $\mathrm{MgO}$ and $\mathrm{P}_{2} \mathrm{O}_{5}$ recovery in dolomite flotation float as a function of flotation $\mathrm{pH}$

The interactions between dissolved mineral species and surfactants leading to precipitation play a crucial role in many industrial processes as in flotation of sparingly soluble minerals. Particularly in beneficiating phosphate rock containing carbonaceous gangue minerals such as calcite and dolomite, the process is complicated by the similarities in the chemical composition and the semi-soluble property of the constituent minerals (Hanna and Somasundaran, 1976). Poor separation selectivity is often reported in many flotation schemes (Moudgil and Somsundaran, 1986). Xiao and co-workers (1989) in their fundamental studies found that surface conversion and dissolved mineral 
species-surfactant interactions were major reasons for poor selectivity in flotation separation of various salt-type mineral systems. They pointed out that effective control of the end applications made it essential to elucidate the mechanism involved in the interactions of surfactants with dissolved mineral species from salt-type minerals. In this study, $\mathrm{Ca}^{2+}$ and $\mathrm{Mg}^{2+}$ concentrations in the flotation slurry of natural dolomitic phosphate ore at different flotation $\mathrm{pH}$ were measured and the results are plotted in Fig. 4-30.

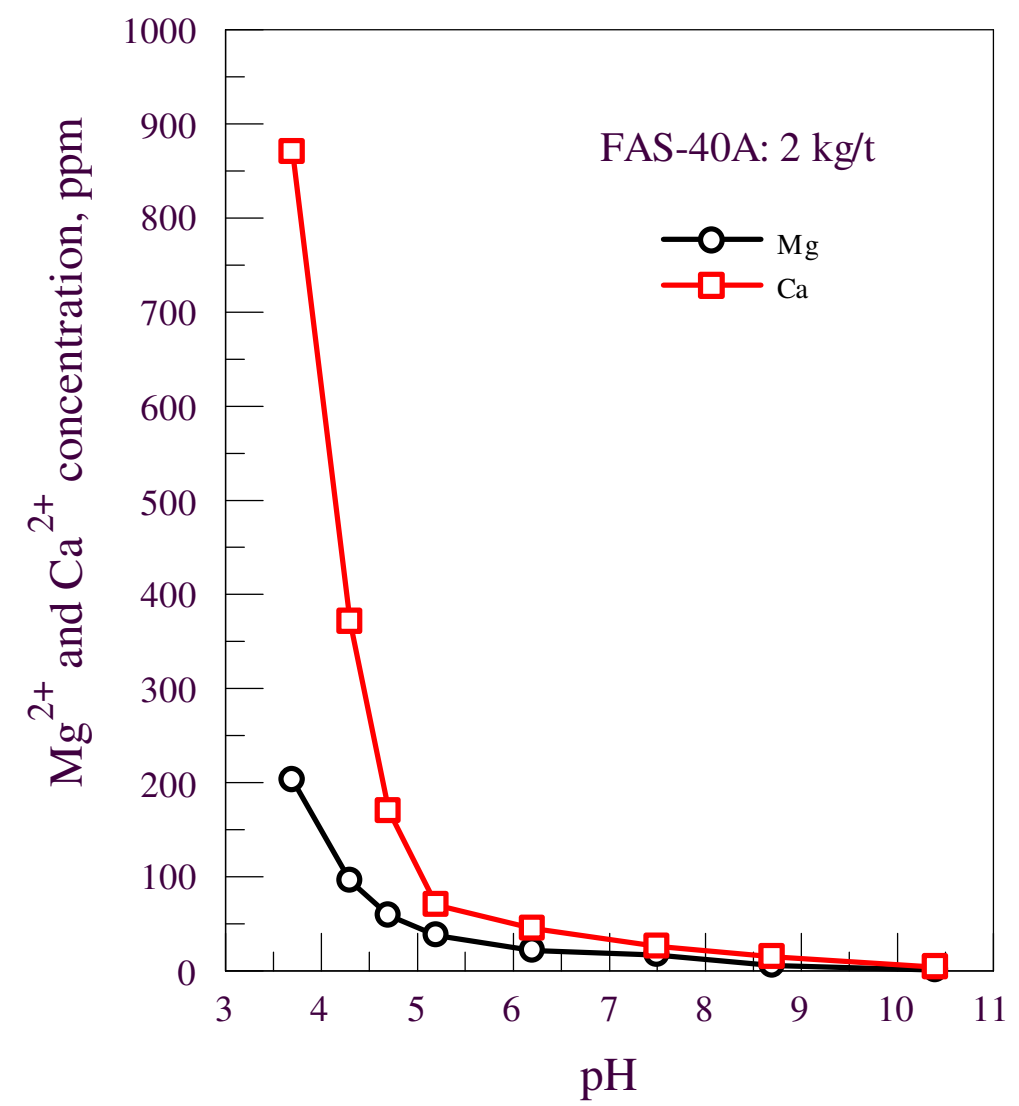

Fig. 4-30 $\mathrm{Ca}^{2+}$ and $\mathrm{Mg}^{2+}$ concentration in the solution of flotation slurry of natural dolomitic phosphate as a function of $\mathrm{pH}$

Both $\mathrm{Ca}^{2+}$ and $\mathrm{Mg}^{2+}$ concentrations increase with the decrease of $\mathrm{pH}$. It can be observed that there is a sudden increase of $\mathrm{Ca}^{2+}$ and $\mathrm{Mg}^{2+}$ concentrations below $\mathrm{pH} 5$. 
$\mathrm{Ca}^{2+}$ concentration is much higher than $\mathrm{Mg}^{2+}$ because $\mathrm{Ca}^{2+}$ is dissolved from dolomite, calcite and phosphate, and $\mathrm{Mg}^{2+}$ only from dolomite. Xiao and co-workers (1989) conducted studies on surface and bulk precipitation of oleate in francolite and dolomite flotation system using pure mineral samples. They found that dissolved calcium and magnesium ions reacted with oleate to form $\mathrm{Ca}$ and $\mathrm{Mg}$ oleates which lead to depletion of the collector in the flotation system. Formation of $\mathrm{Ca}$ and $\mathrm{Mg}$ oleates on the mineral surface as well as in the bulk solution resulted in surface and bulk precipitations. They concluded that the interactions between dissolved mineral species and oleate leading to the formation of surface and bulk precipitates might attribute to the loss of selectivity in oleate flotation of francolite and dolomite. Fig. 4-31 presents $\mathrm{Ca}^{2+}$ and $\mathrm{Mg}^{2+}$ concentration at different $\mathrm{pH}$ with and without FAS-40A collector and DSS1 surfactant. It shows that there is not much difference in $\mathrm{Ca}^{2+}$ and $\mathrm{Mg}^{2+}$ concentration in the presence or absence of FAS-40A collector. It seems that there is a slight reduction in $\mathrm{Ca}^{2+}$ and $\mathrm{Mg}^{2+}$ concentration at acidic $\mathrm{pH}$ when $10 \%$ DSS1 surfactant is added. 


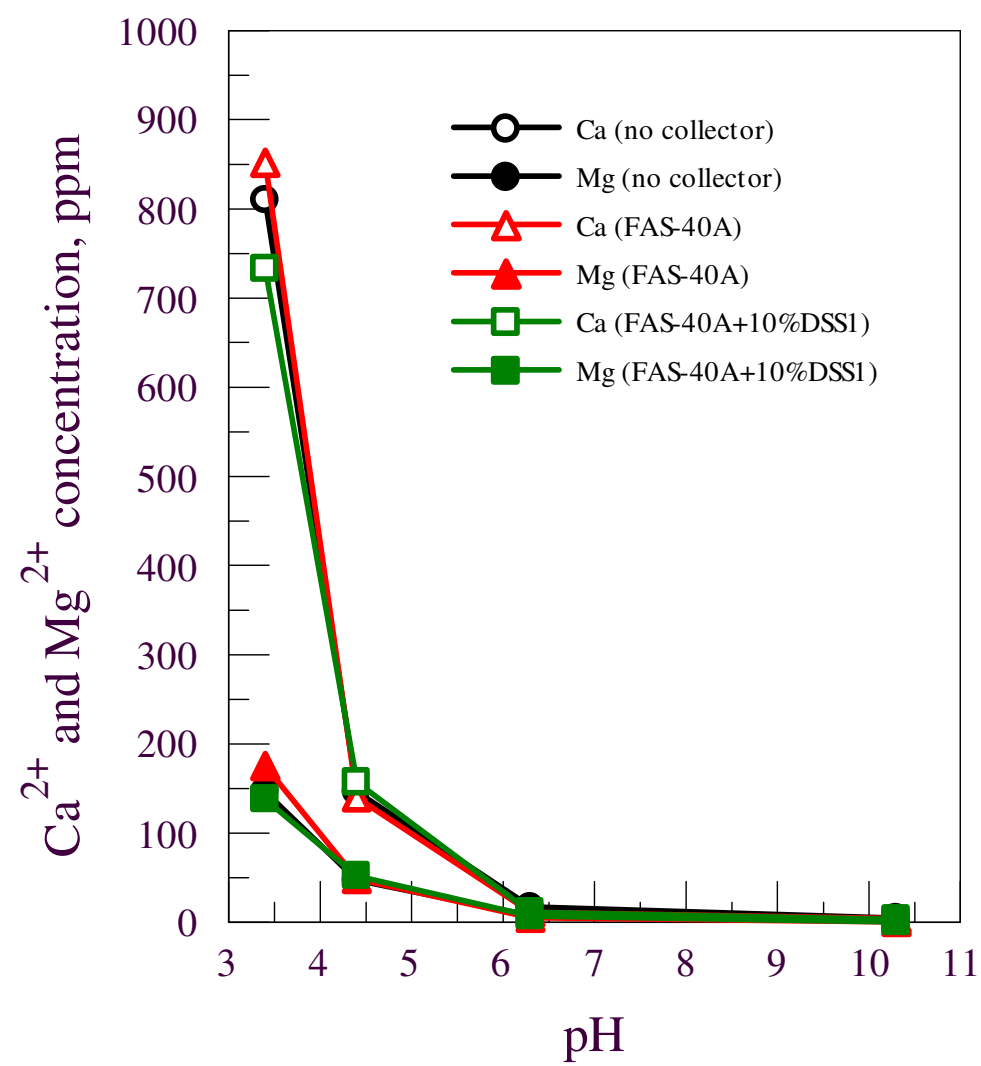

Fig. 4-31 Effect of FAS-40A collector and DSS1 surfactant on $\mathrm{Ca}^{2+}$ and $\mathrm{Mg}^{2+}$ at different $\mathrm{pH}$

\subsubsection{Surfactant Effect on Dolomite Flotation for Sample H}

Three surfactants selected in this study include diethyl phthalate (DP), Tween- 80 (TW) and derivative of sulfate salt (DSS1). Based on the measurements of frothability and froth stability as well as Hallimond cell flotation results, $10 \%$ of the selected surfactants was mixed with FAS-40A collector for dolomite flotation of sample H. Fig. 4-32 shows the effect of selected surfactants on the weight percentage of the float of dolomite flotation with FAS-40A as collector. The figure shows that the yields for both 
TW and DSS1 do not have much difference with or without any surfactant when the collector dosages are in the range of 0.5 to $2.0 \mathrm{~kg} / \mathrm{t}$. At the low collector dosage in the range of 0.5 to $1.5 \mathrm{~kg} / \mathrm{t}$, using DP can significantly increase the weight percentage of the float of dolomite flotation. The curve levels off after collector dosage is further increased from $1.5 \mathrm{~kg} / \mathrm{t}$ to a higher dosage. At the collector dosage higher than $2 \mathrm{~kg} / \mathrm{t}$, the yields of dolomite float were nearly the same for DP, TW and no surfactant, while the yield was significantly increased when DSS1 was used. It seems that the result in Fig. 4-32 is, to some extent, related to the frothability measurement results expressed in Figs. 4-5 and 4-6. In Figs. 4-5 and 4-6, when the percentage of the surfactant in FAS-40A was smaller than 6\%, DP produced more bubbles than TW and DSS1. After 6\%, DSS1 generated more bubbles than DP and TW. 


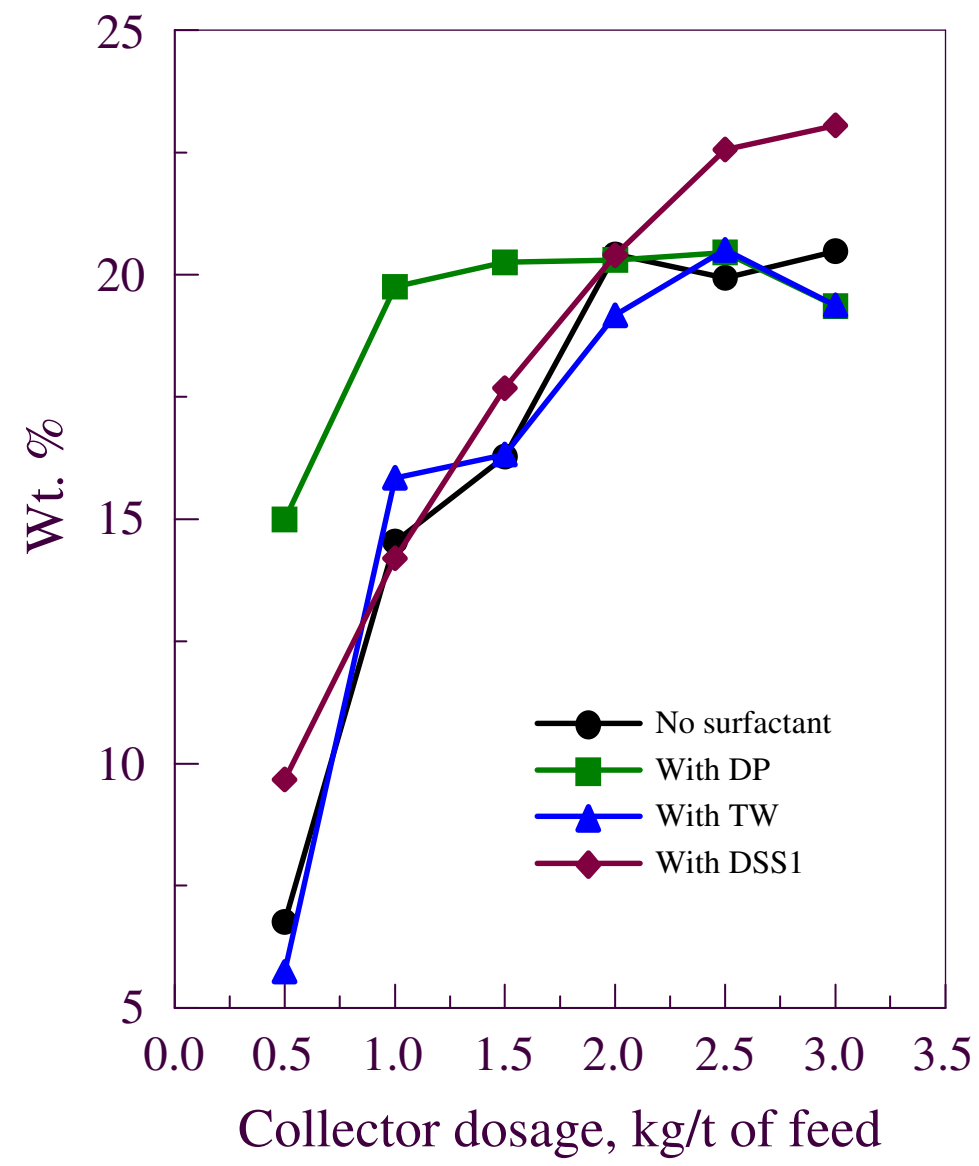

Fig. 4-32 Effect of selected surfactants on the weight percentage of the float using

FAS-40A collector with and without surfactant

Figs. 4-33 and 4-34 show the effect of different surfactants on $\mathrm{MgO}$ grade and recovery in the dolomite flotation float. From Fig. 4-33, it can be observed that when DSS1 is used, $\mathrm{MgO}$ grade is much higher in the float of the dolomite flotation compared to using DP, TW or no surfactant. In the reverse flotation of dolomitic phosphate ores, $\mathrm{MgO}$ grade in the float usually decreases with the increase of the collector dosage. When the collector dosage is in the range of 1.0 to $3.0 \mathrm{~kg} / \mathrm{t}$, the $\mathrm{MgO}$ grade in the float is significantly higher by DSS1 surfactant than any other surfactant or FAS-40A alone. The 
$\mathrm{MgO}$ grade in the float is relatively constant and does not show much fluctuation with the increase of the collector dosage.

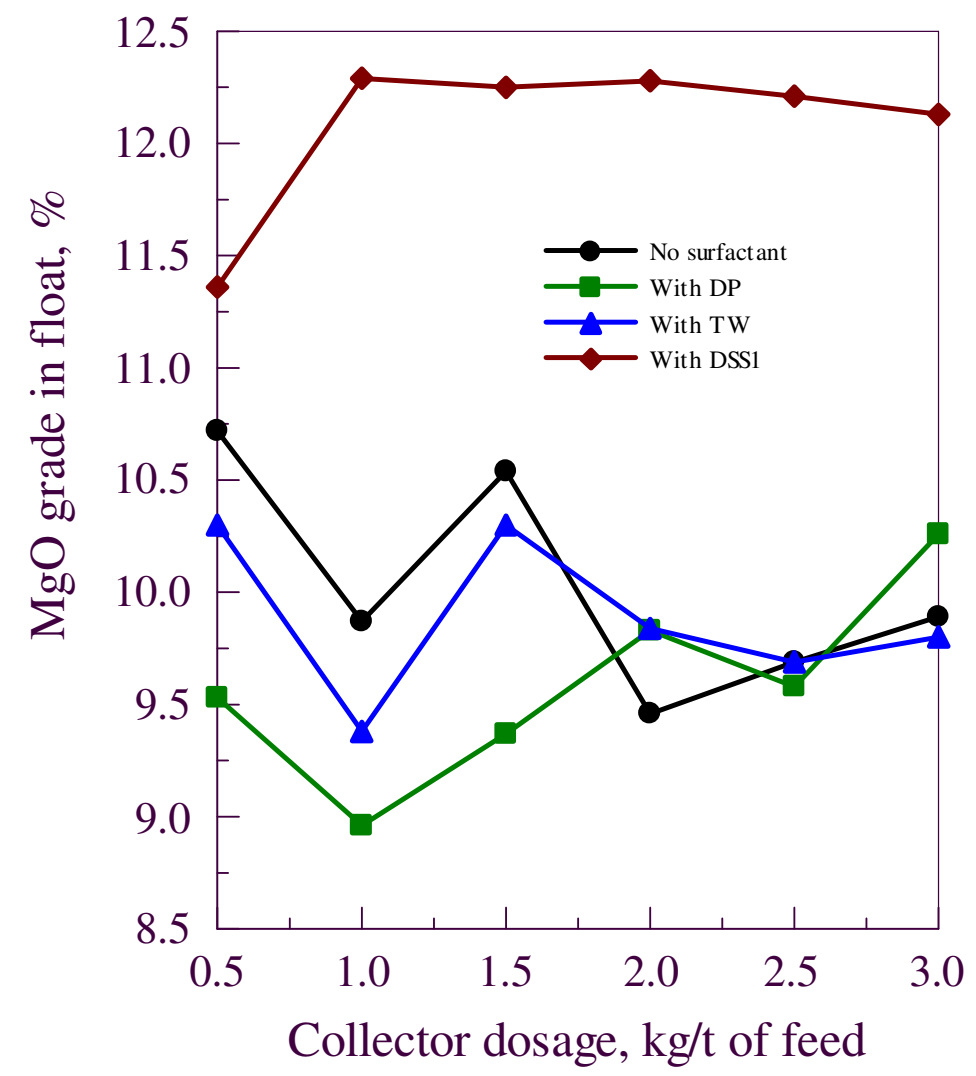

Fig. 4-33 Effect of selected surfactants on $\mathrm{MgO}$ grade in float using FAS-40A collector with and without surfactant

Fig. 4-34 shows the $\mathrm{MgO}$ recovery in the dolomite flotation float as a function of FAS-40A dosage with and without selective surfactants. It can be observed that TW has no effect on the $\mathrm{MgO}$ recovery in the float. At the collector dosage less than $1.5 \mathrm{~kg} / \mathrm{t}$, the $\mathrm{MgO}$ recovery in the float is the highest with DP and second with DSS1. If collector dosage increases to more than $2.0 \mathrm{~kg} / \mathrm{t}$, there is not much difference between FAS-40A alone and the results of adding DP, or TW. But the difference is very significant when 
DSS1 is used. At this collector dosage range, about 15\% more dolomite can be floated compared with using DP, TW or FAS-40A only.

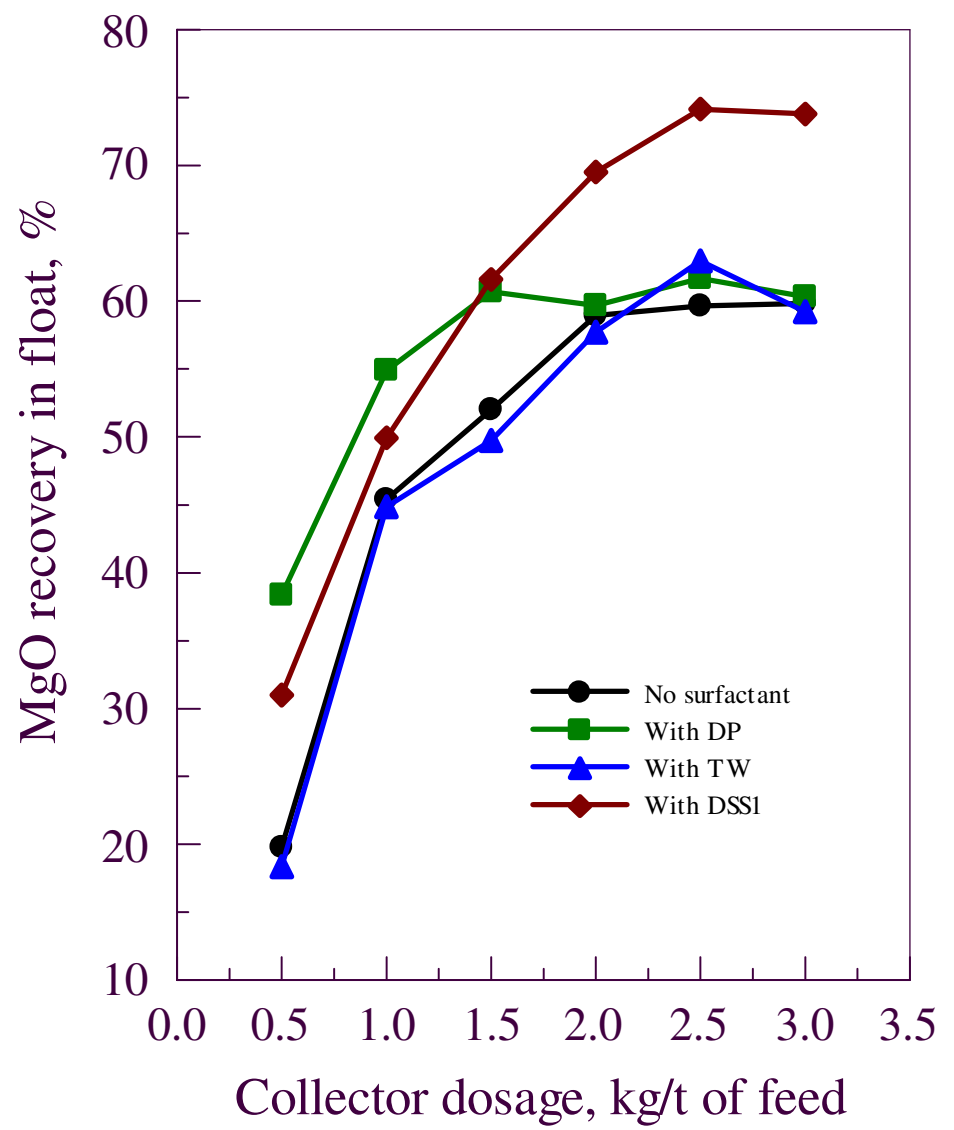

Fig. 4-34 Effect of selected surfactants on $\mathrm{MgO}$ recovery in float using FAS-40A collector with and without surfactant

Fig. 4-35 presents the $\mathrm{P}_{2} \mathrm{O}_{5}$ grade in the dolomite flotation float with and without the presence of surfactants. There is no significant difference between DP, TW and no surfactant. When DSS1 is used, the $\mathrm{P}_{2} \mathrm{O}_{5}$ grade in the float increases with the increase of collector dosage greater than $1.0 \mathrm{~kg} / \mathrm{t}$. However, the float of dolomite flotation has much lower $\mathrm{P}_{2} \mathrm{O}_{5}$ grade than using any other surfactants or no surfactant. 


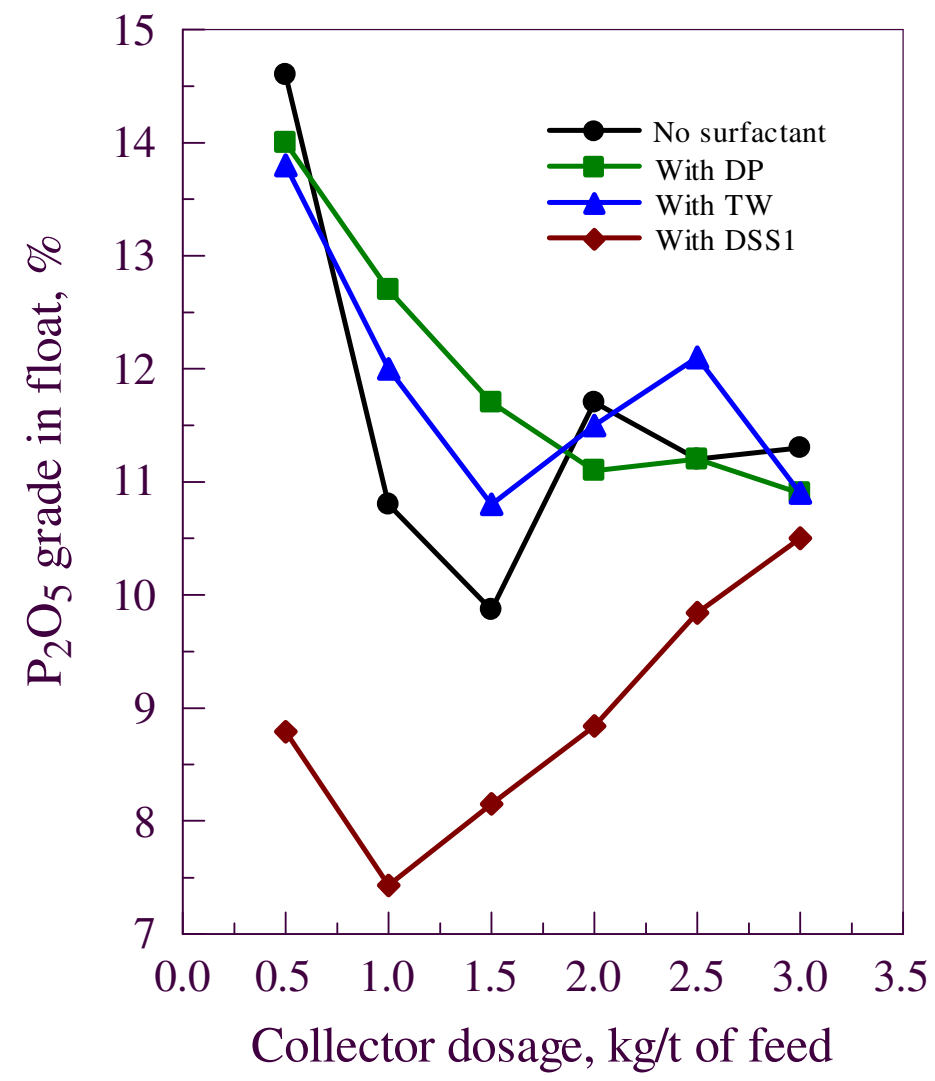

Fig. 4-35 Effect of selected surfactants on $\mathrm{P}_{2} \mathrm{O}_{5}$ grade in sink using FAS-40A collector with and without surfactant

Fig. 4-36 presents the tendency of $\mathrm{P}_{2} \mathrm{O}_{5}$ loss in the dolomite flotation tailings with and without surfactants. At FAS-40A dosage less than $2.0 \mathrm{~kg} / \mathrm{t}, \mathrm{P}_{2} \mathrm{O}_{5}$ loss is higher with DP. It is interesting to note that $\mathrm{P}_{2} \mathrm{O}_{5}$ loss does not increase with the collector dosage in this case, contrary to the typical results. It indicates that DP does not improve selectivity in dolomite flotation. Lu and Sun (1999) used 5\% DP in a dolomite flotation collector PA-31. It was reported that PA-31 could improve the selectivity of dolomite flotation when it was used as collector. The explanation to the selectivity improvement is that the 
viscosity of froth was reduced which improved the dolomite flotation performance. Although DP can improve the flotation selectivity of separating dolomite from phosphate, it has little effect on the collecting ability, particularly at collector dosages of more than 2 $\mathrm{kg} / \mathrm{t}$, which can be observed in Fig. 4-36. $\mathrm{P}_{2} \mathrm{O}_{5}$ loss in the dolomite flotation float for TW is nearly the same as that for no surfactant used. When DSS1 was used, the dolomite flotation float contained less $\mathrm{P}_{2} \mathrm{O}_{5}$ which resulted in less $\mathrm{P}_{2} \mathrm{O}_{5}$ loss into the dolomite tailings.

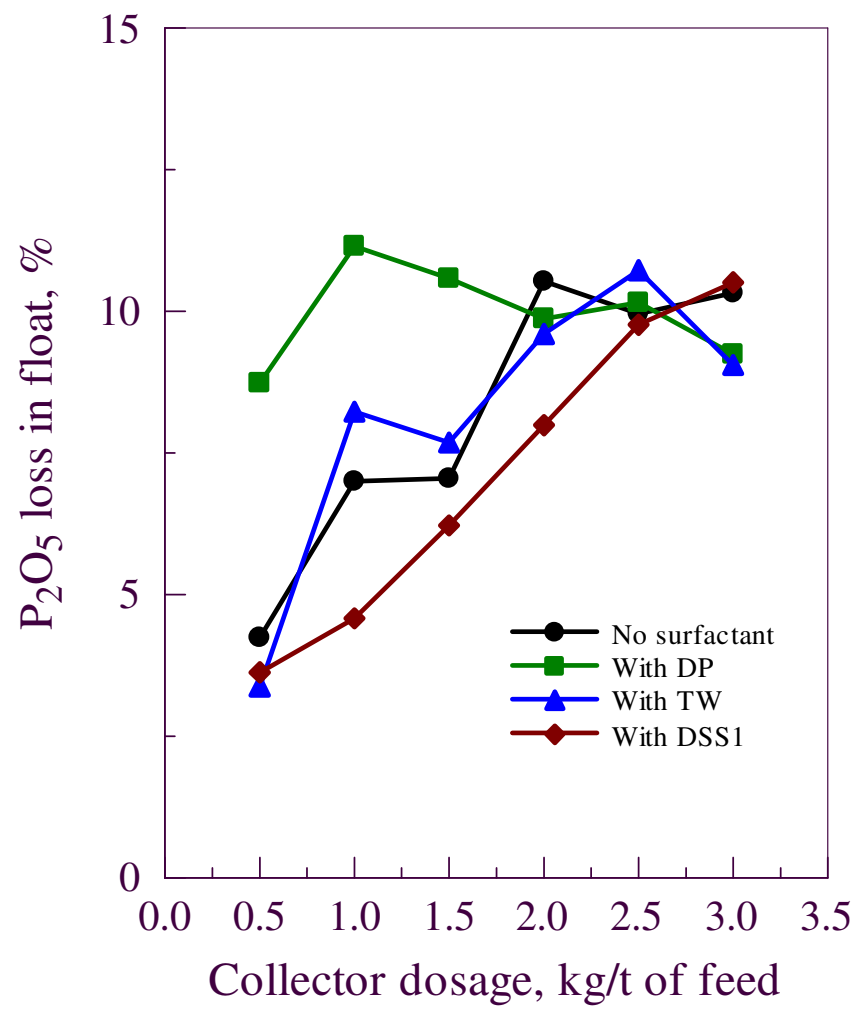

Fig. 4-36 Effect of selected surfactants on $\mathrm{P}_{2} \mathrm{O}_{5}$ loss in dolomite tailings using FAS-40A collector with and without surfactant 
Fig. 4-37 plots the $\mathrm{MgO}$ content in the sink of dolomite flotation as a function of FAS-40A collector dosages with and without surfactants. There is a tendency that $\mathrm{MgO}$ content in the sink product decreases with the increase of collector dosages for all three surfactants used and without surfactant. At FAS-40A dosage lower than $1.5 \mathrm{~kg} / \mathrm{t}$, DP gives the lowest $\mathrm{MgO}$. DSS1 can generate a sink product with the lowest $\mathrm{MgO}$ at collector dosage higher than $1.5 \mathrm{~kg} / \mathrm{t}$. At the dosages higher than $2.5 \mathrm{~kg} / \mathrm{t}$, all four curves level off. It indicates that there will be little advantage by further increasing the collector above this dosage. It can be seen from this figure that the effectiveness of the selected surfactants functioning in improving dolomite flotation is in the order of DSS1 $>$ DP $>$ TW $>$ no surfactant. 


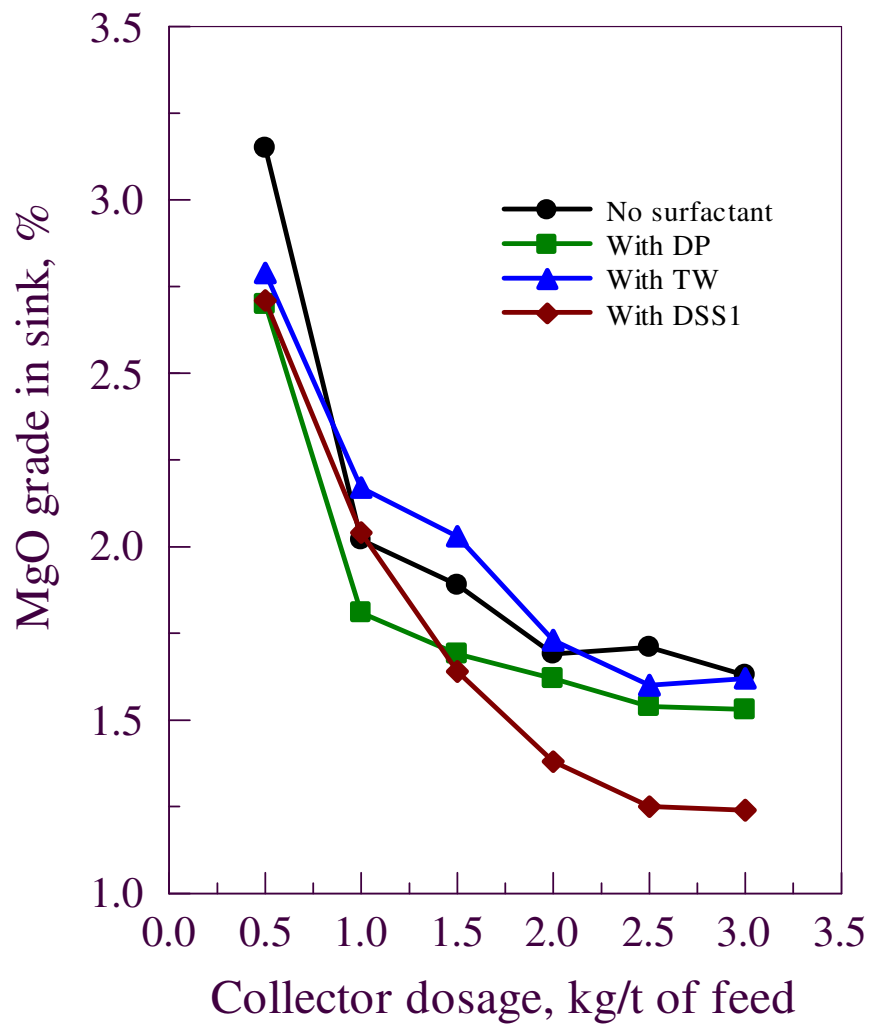

Fig. 4-37 Effect of selected surfactants on $\mathrm{MgO}$ grade in sink using FAS-40A collector with and without surfactant

\subsubsection{Surfactant Effect on Silica Flotation}

The acid insoluble contained in phosphate ore includes quartz and some silicates. Generally, acid insoluble is not a serious concern in double flotation process. After dolomite flotation or phosphate flotation, further processing procedures are required to remove silicates in order to produce a final phosphate concentrate acceptable by market for fertilizer manufacturing. Most siliceous gangue minerals can be rejected through amine flotation. Fig. 4-38 shows the acid insoluble content in dolomite flotation floats 
with and without surfactants. From Fig. 4-38, it is difficult to tell the difference in acid insoluble content when using DP, TW or no surfactant. However, it is noted that the amount of acid insoluble in the dolomite flotation float is significantly lower when DSS1 is used. The explanation to less silica floated in the froth product using DSS1 is not well defined in this study. One possible reason is that more dolomite is recovered into float due to the utilization of surfactant DSS1. On the other hand, the phosphate in the float does not increase significantly compared to dolomite floated. The froth product contains more dolomite and the amount of phosphate is almost same. The quantity of acid insoluble in the float will decrease in order to maintain the overall material balance of the product. Another possible reason is that utilization of DSS1 can prevent the adsorption of fatty acid collector on the surface of silica particles and reduce the amount of silica to be floated into froth product. The Fig. 4-38 shows that DSS1 can prevent the flotation of acid insoluble. This fact may be applied in other processes. 


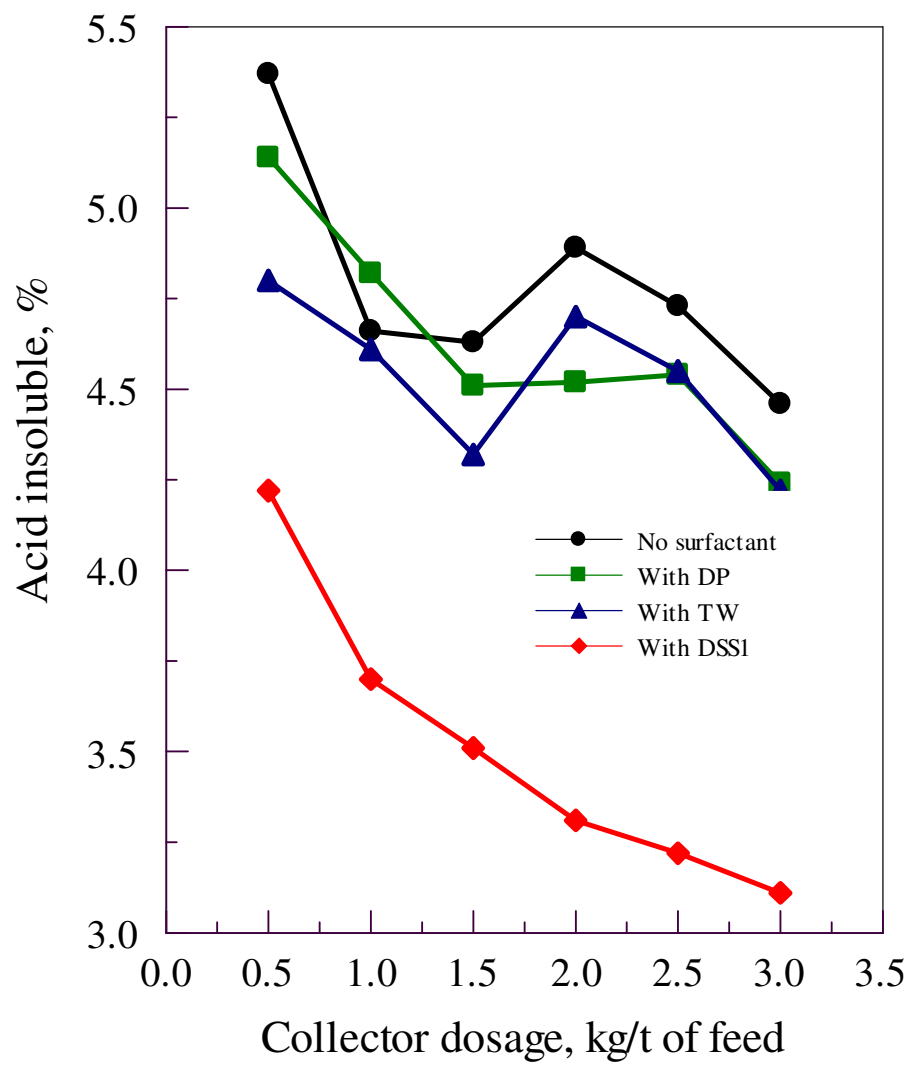

Fig. 4-38 Effect of selected surfactants on acid insoluble in float using FAS-40A collector with and without surfactant

\subsubsection{Surfactant Effect on Bubble Size}

From the flotation results of dolomitic phosphate sample with high $\mathrm{MgO}$ grade shown in Figs. 4-33, 4-34, 4-35, 4-36 and 4-37, it can be seen that DSS1 could significantly improve the flotation of dolomite from phosphate while it was used with fatty acid collector. There was not much difference in weight percenatge of dolomite flotation tailings when different surfactants were used or without surfactant except that DP increased the weight percentage of tailings in rather higher percentage at low fatty 
acid collector dosages. However, if fatty acid was mixed with $10 \%$ DSS1, the float of dolomite flotation contained much higher $\mathrm{MgO}$ for removal of dolomite. The sink contained much less $\mathrm{MgO}$ compared with other surfactants or no surfactant. The $\mathrm{P}_{2} \mathrm{O}_{5}$ loss into the float of dolomite flotation was less than using other surfactants or without surfactant. The utilization of DSS1 resulted in the significant improvement in the selectivity of dolomite flotation.

From the curves shown in Figs. 4-32 to 4-38, it can be clearly seen that in cases with DP, TW or without surfactant, the test results are erratic as the reagent dosages increase. It shows that the data fluctuated and the operation was not quite stable.

When DSS1 was used, the flotation results are well related to the reagent dosagess. For instance, the $\mathrm{MgO}$ grade in the float of dolomite flotation has not much change with the increase of collector dosage beyond $1.0 \mathrm{~kg} / \mathrm{t}$ as shown in Fig. 4-33. The weight percentage of the dolomite flotation float, and $\mathrm{MgO}$ and $\mathrm{P}_{2} \mathrm{O}_{5}$ recoveries in the float increase constantly as the collector dosage is increased as illustrated in Figs. 4-32, 4-34and 4-36. The $\mathrm{MgO}$ grade in sink and the acid insoluble in float decrease consistently with increasing the collector dosages as shown in Figs. 4-37 and 4-38. The test results show that when DSS1 is used, the flotation performance can be readily controlled by the adjustment of reagent dosages after other conditions are fixed, such as air flow rate of aeration, impeller speed of flotation machine, $\mathrm{pH}$ and temperature of flotation slurry, etc.

During the operation of dolomite flotation in batch flotation cell using natural dolomitic phosphate ores as feed, it was also found that DSS1 can significantly improve 
the properties of the froth product. When FAS-40A is used alone without any surfactant, the bubble size is quite big, up to more than ten millimeters. It is difficult for the bubbles to be broken and to coalesce. It is also clearly seen that those big bubbles are not well mineralized. After the froth is removed from flotation cell to the container, those bubbles are very stable and stay there for quite a long time. When DSS1 is used with FAS-40A, it totally changes the properties of the froth product. The bubble size becomes much smaller and very homogeneous. The bubble size is around 1 millimeter. Those smaller bubbles are very well mineralized and carry more dolomite particles. They are also very coalescent and easily broken. Fig. 4-39 illustrates the differences in the froth products of dolomite flotation with and without surfactant DSS1.

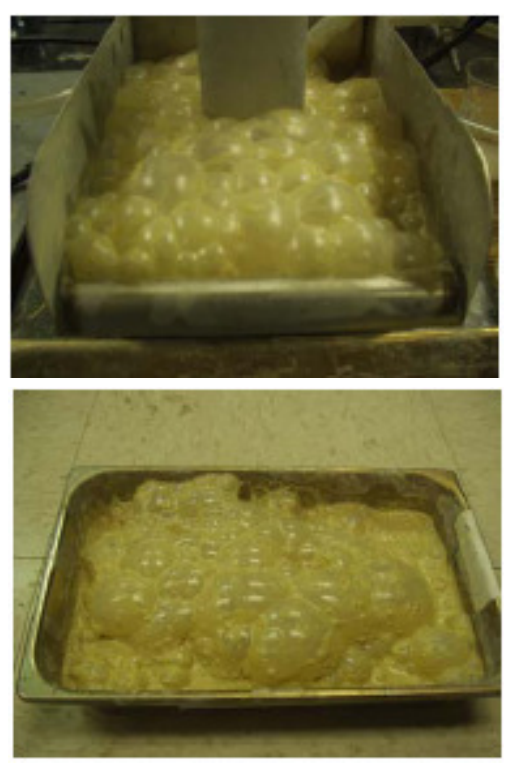

(a)
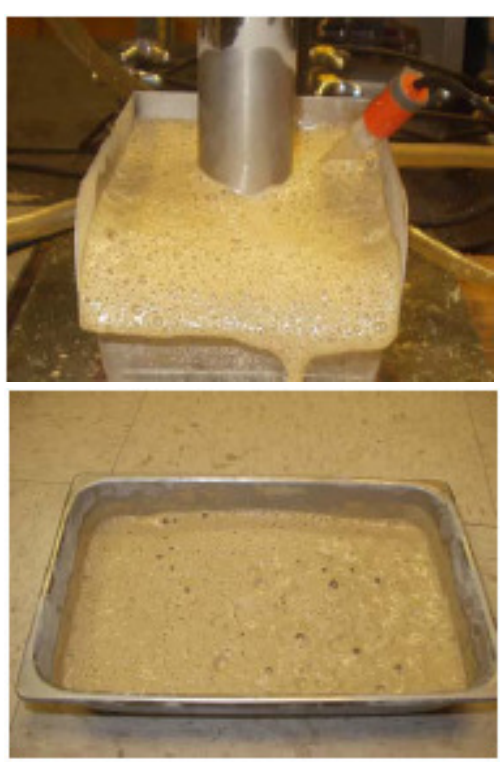

(b)

Fig. 4-39 Photos showing difference in froth product with and without DSS1

(a) without surfactant; (b) with $10 \%$ DSS1 


\subsection{5 pH Effect on Dolomite Flotation in Presence of DSS1}

Dolomite flotation is usually conducted in acidic solution ranging from $\mathrm{pH} 3.5$ to $\mathrm{pH}$ 6 (Peng and $\mathrm{Gu}, 2005$ ). The optimum $\mathrm{pH}$ for dolomite flotation from phosphate is reported to be between 5.0 and 5.5 (Somasundaran et al. 1987). The fact that the best dolomite flotation can be achieved at acidic $\mathrm{pH}$ has not been well addressed. The two most common explanations include (i) adsorption of $\mathrm{CaHPO}_{4}$ on the phosphate surface leading to the depression of phosphate (Elgrilani and Abouzeid, 1993), and (ii) generation of $\mathrm{CO}_{2}$ in acidic solution facilitating the flotation of dolomite (Moudgil and Chanchani, 1985). In this study, flotation tests were conducted to evaluate the effect of slurry $\mathrm{pH}$ on separation performance when FAS-40A was used alone and combined with $10 \%$ surfactant DSS1. Figs. 4-40 and 4-41 present the grade and recovery of both $\mathrm{MgO}$ and $\mathrm{P}_{2} \mathrm{O}_{5}$ in the float of dolomite flotation as a function of flotation pH. Fig. 4-40 shows that both $\mathrm{MgO}$ grade and recovery decrease with the increase of flotation $\mathrm{pH}$. At $\mathrm{pH} 5.0, \mathrm{MgO}$ grade in the float is $9.69 \%$ without any surfactant and $12.21 \%$ with $10 \%$ DSS1. When flotation $\mathrm{pH}$ is increased from 5.0 to $6.0, \mathrm{MgO}$ grade is decreased to $9.08 \%$ and $8.92 \%$, respectively. It can be observed that, in the $\mathrm{pH}$ range studied, the float of dolomite flotation contains higher $\mathrm{MgO}$ grade and more dolomite can be rejected into dolomite tailings. When surfactant DSS1 is used, over 11\% more dolomite can be floated. At pH 5, the difference in both $\mathrm{MgO}$ grade and recovery in the float of dolomite flotation between no surfactant and in the presence of DSS1 is more significant than at $\mathrm{pH} 6$. 


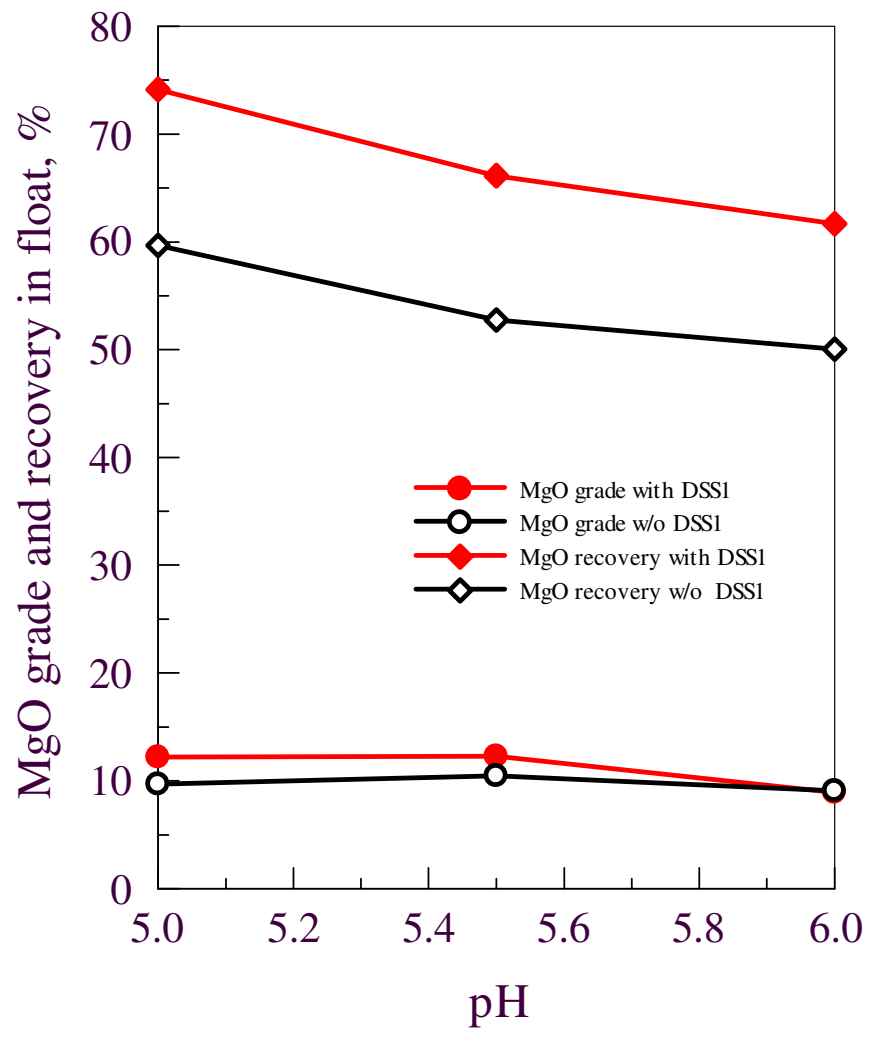

Fig. 4-40 pH effect on $\mathrm{MgO}$ grade and recovery in float using FAS-40A collector with and without DSS1

Fig. 4-41 illustrates that the $\mathrm{P}_{2} \mathrm{O}_{5}$ grade and recovery (loss of $\mathrm{P}_{2} \mathrm{O}_{5}$ ) in the float of dolomite flotation increase with the increase of flotation $\mathrm{pH}$. Such increase is very sharp from $\mathrm{pH} 5.3$ to $\mathrm{pH} 5.8$ for both without surfactant and with DSS1. The flotation results show that flotation $\mathrm{pH}$ has significant effect on the performance of separating dolomite from phosphate. The dolomite flotation float with higher $\mathrm{MgO}$ content and lower $\mathrm{P}_{2} \mathrm{O}_{5}$ grade can be produced at low $\mathrm{pH}$ 5.0. Consequently at this $\mathrm{pH}$, more dolomite can be 
discarded with less $\mathrm{P}_{2} \mathrm{O}_{5}$ loss. In other words, the flotation selectivity of separating dolomite from phosphate can be significantly improved at low $\mathrm{pH}$.

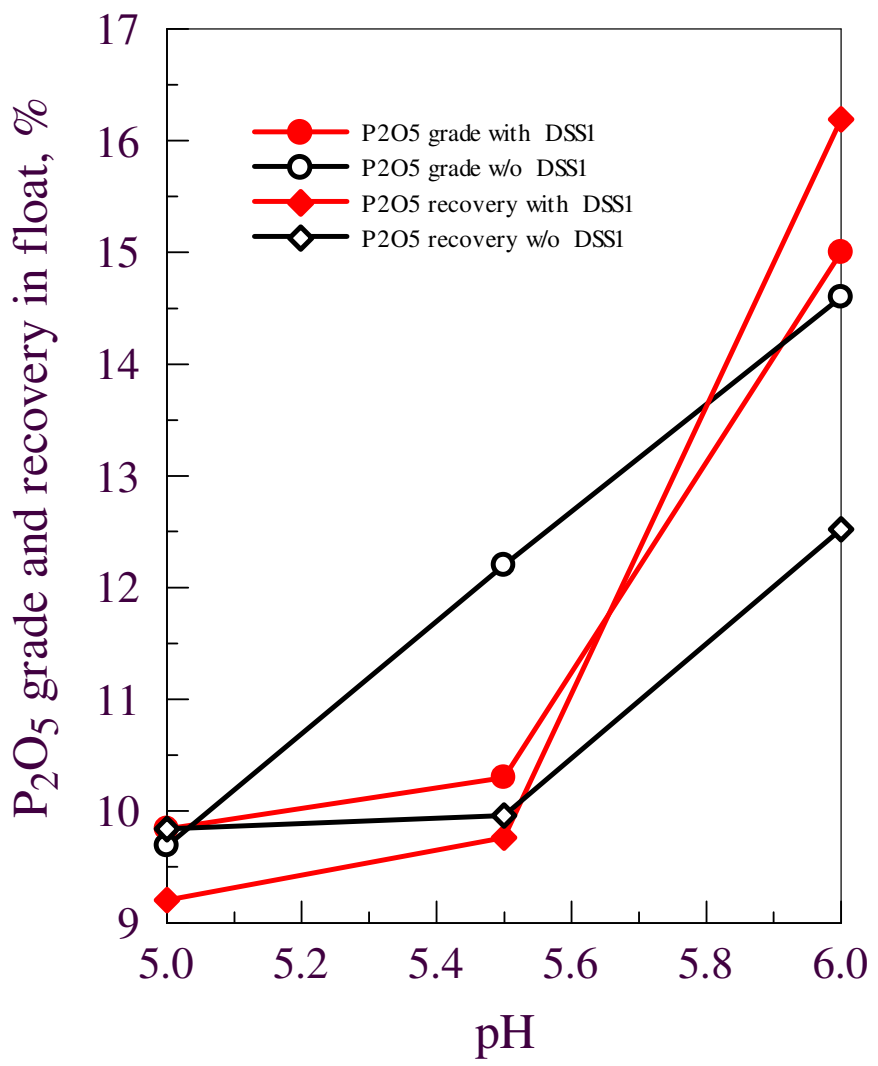

Fig. 4-41 pH effect on $\mathrm{P}_{2} \mathrm{O}_{5}$ grade and recovery in float using FAS-40A collector with and without DSS1

\subsubsection{Flotation Tests on Dolomitic Phosphate Sample L}

The results of flotation tests for sample $\mathrm{H}$ with higher $\mathrm{MgO}$ demonstrate that utilization of surfactant DSS1 in dolomite flotation with fatty acid soap as collector can significantly improve the separation selectivity. In order to determine whether the 
combination of surfactant DSS1 and fatty acid collector on other dolomitic phosphate ores, further flotation tests were carried out with sample L which contained lower $\mathrm{MgO}$, about $1.5 \%$. The chemical analysis of sample $\mathrm{L}$ and the size distribution and chemical analysis of the flotation feed after grinding are presented in Tables A-5 and A-8 in Appendix A. The same flotation cell and reagents were used except that different reagent dosages were used due to different characteristics of sample L. The results are plotted in Figs. 4-42, 4-43 and 4-44. Fig. 4-42 shows the $\mathrm{MgO}$ grade and recovery in the float of dolomite flotation in the presence and absence of surfactant DSS1 as a function of collector dosages. The utilization of surfactant with fatty acid soap collector can increase both $\mathrm{MgO}$ grade and recovery in the float. It can be noticed that when DSS1 is added, the $\mathrm{MgO}$ grade is about 2\% higher than that without using DSS1. This means that about $10 \%$ more dolomite can be rejected. 


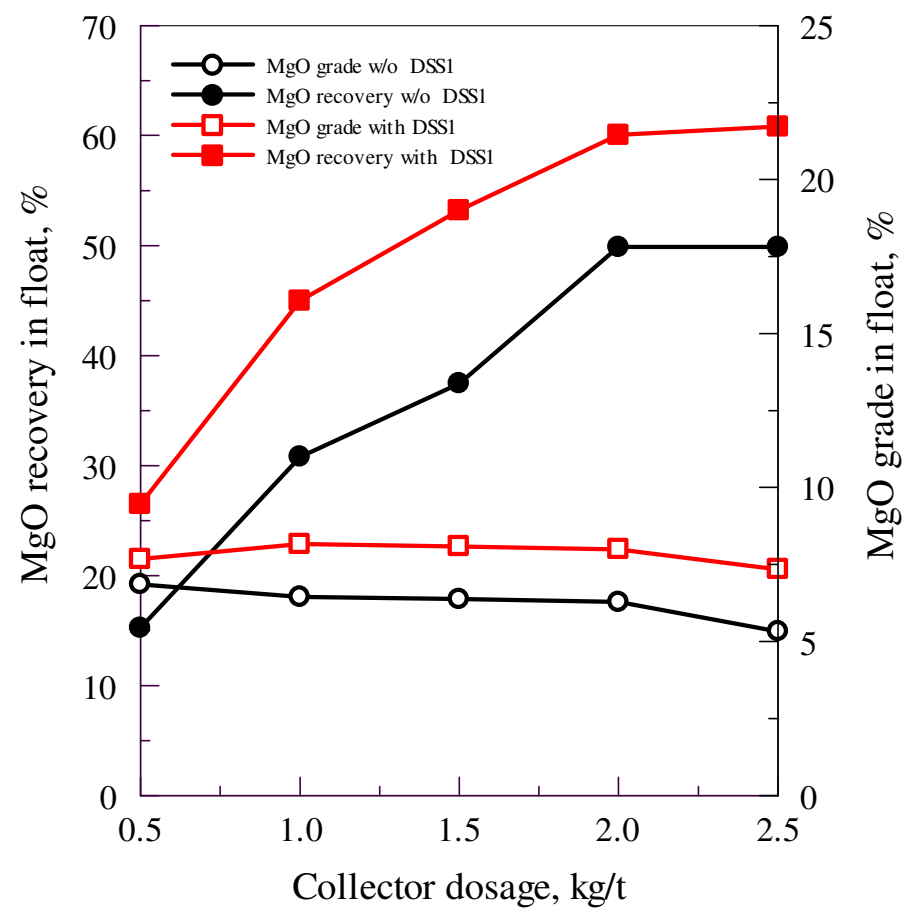

Fig. 4-42 $\mathrm{MgO}$ grade and recovery in the dolomite flotation float as a function of collector dosage with and without surfactant DSS1

Fig. 4-43 shows when the mixture of FAS-40A and DSS1 is used for dolomite flotation, better separation performance can be obtained. For example, at the collector dosage of $2.0 \mathrm{~kg} / \mathrm{t}$ FAS-40A and $0.2 \%$ DSS1, the sink of dolomite flotation contains $28.2 \% \mathrm{P}_{2} \mathrm{O}_{5}$ and $0.6 \% \mathrm{MgO}$. If $2.0 \mathrm{~kg} / \mathrm{t}$ of FAS- $40 \mathrm{~A}$ is utilized alone, it contains $27.88 \%$ $\mathrm{P}_{2} \mathrm{O}_{5}$ and $0.8 \% \mathrm{MgO}$. It can be observed that $\mathrm{P}_{2} \mathrm{O}_{5}$ grade is constantly higher than without DSS1, while $\mathrm{MgO}$ content is constantly lower than without DSS1. It demonstrates that the mixture of FAS-40A and DSS1 can significantly improve the separation performance in removing dolomite from dolomitic phosphate ores. 


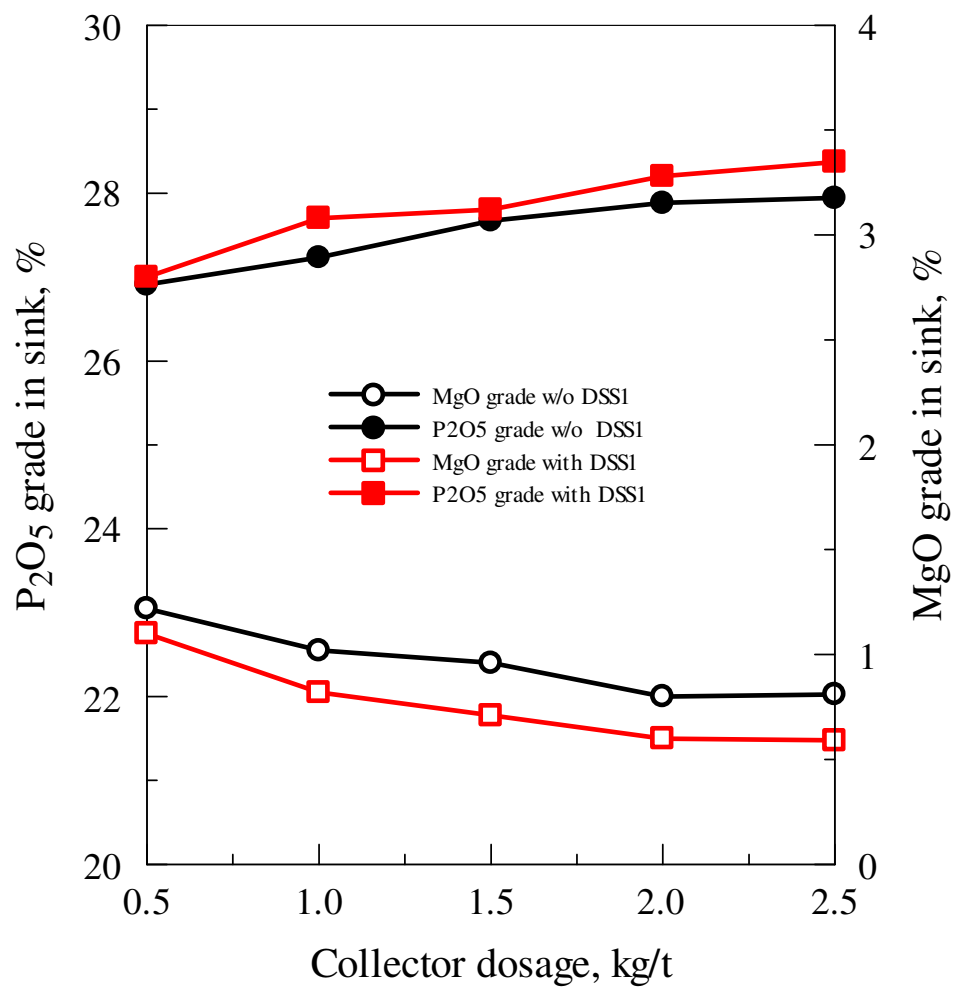

Fig. 4-43 $\mathrm{MgO}$ and $\mathrm{P}_{2} \mathrm{O}_{5}$ grade in the dolomite flotation sink as a function of collector dosage with and without surfactant DSS1

Fig. 4-44 presents $\mathrm{MgO}$ and $\mathrm{P}_{2} \mathrm{O}_{5}$ recoveries in the sink of dolomite flotation as a function of collector dosage in the presence and absence of DSS1. Although there is not much difference in $\mathrm{P}_{2} \mathrm{O}_{5}$ recoveries in the sink products, $\mathrm{MgO}$ recoveries can be significantly lowered by using the mixture of FAS-40A and DSS1. At the dosage of 2.0 $\mathrm{kg} / \mathrm{t}$ of FAS-40A alone, the recoveries of $\mathrm{P}_{2} \mathrm{O}_{5}$ and $\mathrm{MgO}$ in the underflow are $93.0 \%$ and $51.4 \%$, respectively. With addition of $10 \%$ DSS1 in the collector, $\mathrm{P}_{2} \mathrm{O}_{5}$ recovery increases to $94.7 \%$ while $\mathrm{MgO}$ recovery decreases to $40.0 \%$. This means that the separation selectivity is significantly improved. The improvement can also be observed from the 
separation selectivity index curves for dolomite flotation in Fig. 4-44.

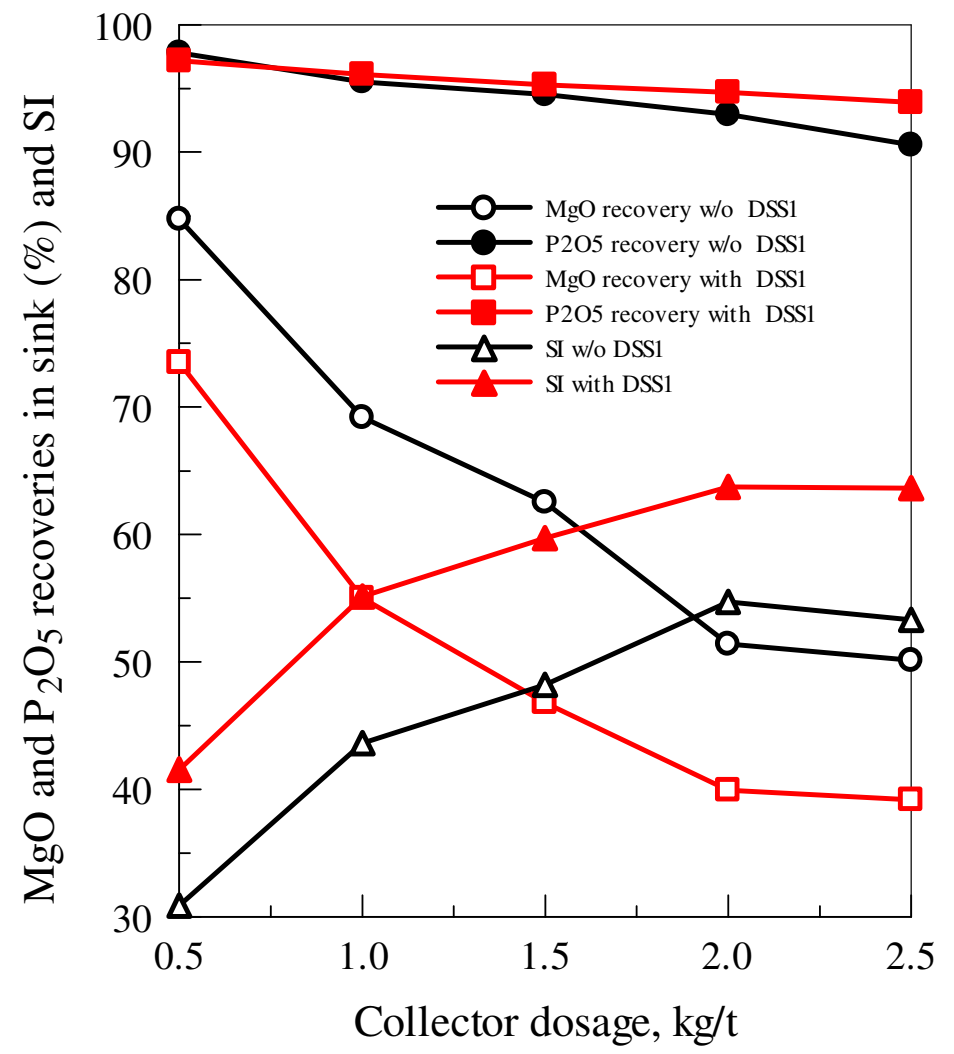

Fig. 4-44 $\mathrm{MgO}$ and $\mathrm{P}_{2} \mathrm{O}_{5}$ recoveries in the dolomite flotation sink as a function of collector dosage and separation selectivity index with and without DSS1

\subsubsection{Dolomite Flotation Results with Different Dolomite Collectors}

Different types of dolomite flotation collectors were used in this study to beneficiate high dolomitic phosphate sample. PA-31 was manufactured in China Lianyungang Design and Research Institute using local cotton seed oil residuals as raw materials. For potential industrial use in the future in U.S., FAS-40A was manufactured by Arr Maz Chemicals, FL. using local fatty acid raw materials, based on the similar procedures of 
manufacturing of PA-31. CCS-500 and CCS-550 are sulfonated fatty acid also developed and produced by Arr-Maz Chemicals for dolomite flotation from phosphate ores. Separation Selectivity Index, SI, for dolomite flotation using collector PA-31, CCS-500, CCS-550, FAS-40A and mixture of FAS-40A and 10\% DSS1 are plotted in Fig. 4-45. It can be seen that selectivity index using FAS-40A is quite close to PA-31. Dosages of CCS-500 and CCS-550 required for dolomite flotation were relatively low due to their good frothability and generation of voluminous bubbles. CCS-500 can produce better separation performance than CCS-550. Among those reagents used in this study, there is no doubt that the mixture of FAS-40A and DSS1 achieved better Selectivity Index than that of any other reagents. 


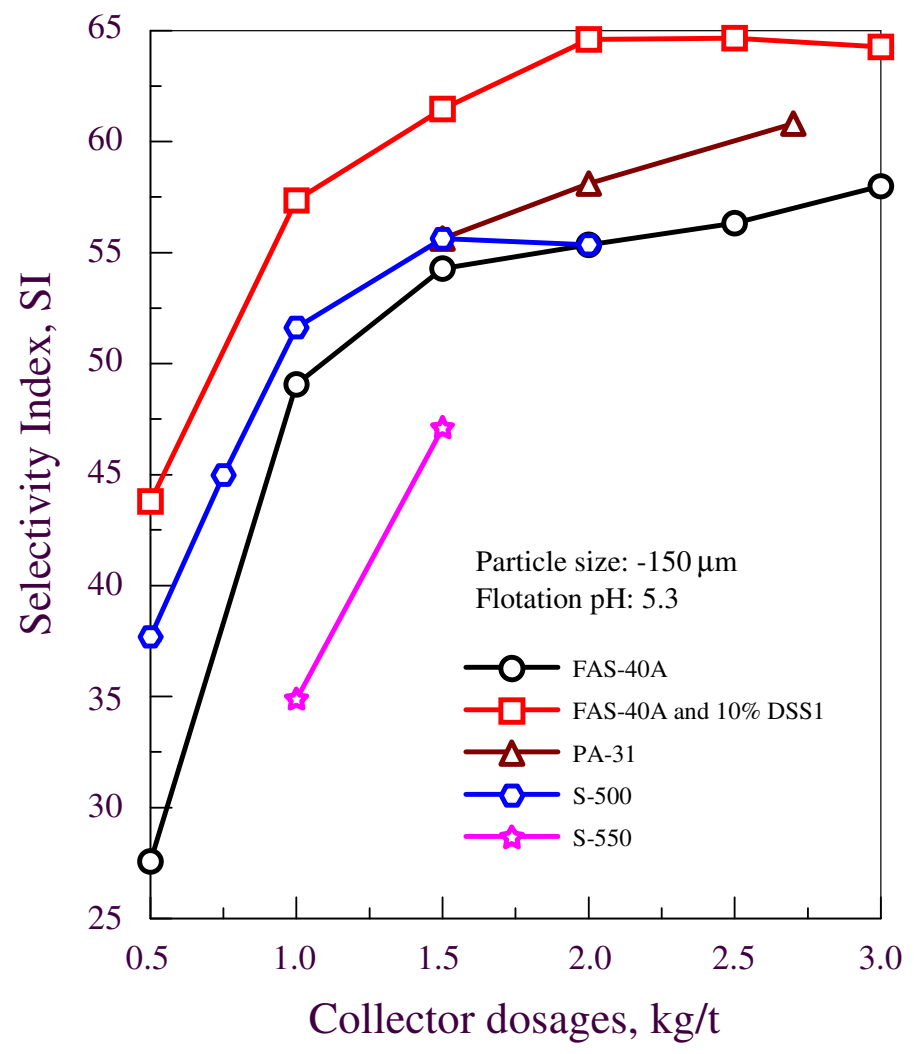

Fig. 4-45 Selectivity Index of dolomite flotation using different dolomite collectors 


\subsection{Packed Column Flotation of Dolomitic Phosphate Ore}

Froth flotation is the most efficient and the most widely used separation technique for beneficiation of fine mineral particles in mineral processing industry. Column flotation, first developed by Boutin and Wheeler (1967), is considered as an advanced froth flotation process. It is well known that column flotation has many advantages over conventional mechanical flotation processes, such as no moving parts, simplicity of construction, less footprint area requirement, low energy consumption, low operation and maintenance costs, high throughput capacity, high product grade and recovery, etc. The factors responsible for these advantages of the flotation column include the countercurrent flow pattern, without mechanical agitation, long residence time, deep and stable froth height, recleaning process by wash water, etc. Since its first invention, a variety of columns has been developed by different investigators, including the Leeds column, the Microcel column, the packed column, the Flotaire column, the hydrochem column and the Jameson column ( $\mathrm{Li}$, et al. 2003).The packed flotation column was developed by Yang (Gu, 2002). It was designed to have a packing bed in an open column to provide smaller and longer torturous flow passages for sufficient time for particle/bubble contact and stabilize the froth layer inside the column. It was claimed that there was no sparger needed compared to open column. In this study, a 2 in. ID and $6 \mathrm{ft}$. height packed column was used. The packing material was made of 0.002 " thickness stainless steel corrugated plates. Each plate has $3 / 4$ " pitch running diagonally at $45^{\circ}$ 
angles. The compressed air is introduced from the bottom of the column and the relatively large size bubbles are generated between packing plates, and between the plates and the wall. The dolomitic phosphate ore sample used as the feed in the dolomite flotation has low content of floatable materials, and low hydrophobicity of carbonate materials. The relatively large size bubbles adhered to hydrophobic particles are not sufficient to produce a high and stable froth layer inside the column due to low content of floatable materials. In order to generate enough small bubbles to form a high and stable froth layer, a ceramic sparger is installed at the bottom of the column to generate small size bubbles as shown in Fig. 3-5. This arrangement of the packed column is a modified packed flotation column.

\subsubsection{Experiment Design for Modified Packed Column Flotation}

Based on previous experience on the original packed column flotation of Florida dolomitic phosphate samples $(\mathrm{Gu}, 2002)$ as well as fine dolomitic phosphate pebble flotation using stirred-tank cell in this study, the control parameters considered in the experiment design included collector dosage, $\mathrm{pH}$, slurry/froth interface level (froth height) and air flowrate. Considering the results of packed column flotation and stirred-tank cell flotation on dolomitic phosphate pebble samples, the operation conditions for the modified packed column flotation in this study were determined and listed in Table 4-2. 
Table 4-2 Conditions for the modified packed column flotation

\begin{tabular}{|c|c|c|c|}
\hline Factors & -1 & 0 & +1 \\
\hline $\mathrm{pH}$ & 4.5 & 5 & 5.5 \\
\hline Collector $(\mathrm{kg} / \mathrm{t})$ & 2 & 2.5 & 3 \\
\hline $\begin{array}{c}\text { Interface }(\mathrm{cm}) \\
\text { (froth height) }\end{array}$ & 10 & 15 & 20 \\
\hline Air rate $(\mathrm{l} / \mathrm{m})$ & 1.5 & 1.8 & 2.1 \\
\hline
\end{tabular}

Central composite design (CCD) was applied for the experiment. The distance from the center of the design space to a factorial point is \pm 1 unit for each factor. The distance from the center of the design space to a star point is $\pm \alpha$. In this case, $\alpha$ value is 1 , then the design is called face centered composite design. According to the output of the JMP software, standard CCD requires 26 runs with 2 center points needed for the experiment design analysis. The coded conditions and natural conditions are arranged as shown in Table 4-3. 
Table 4-3 Experiment design of column flotation tests

\begin{tabular}{|c|c|c|c|c|c|c|c|c|}
\hline \multirow{2}{*}{ Run } & \multicolumn{3}{|c|}{ Coded conditions } & \multicolumn{4}{c|}{ Natural conditions } \\
\cline { 2 - 9 } & $\mathrm{pH}^{1}$ & $\mathrm{CL}^{2}$ & $\mathrm{IF}^{3}$ & $\mathrm{AR}^{4}$ & $\mathrm{pH}$ & $\mathrm{CL}$ & $\mathrm{IF}$ & $\mathrm{AR}$ \\
\hline 1 & -1 & -1 & -1 & -1 & 4.5 & 2 & 10 & 1.5 \\
\hline 2 & 1 & -1 & -1 & -1 & 5.5 & 2 & 10 & 1.5 \\
\hline 3 & -1 & 1 & -1 & -1 & 4.5 & 3 & 10 & 1.5 \\
\hline 4 & -1 & -1 & 1 & -1 & 4.5 & 2 & 20 & 1.5 \\
\hline 5 & -1 & -1 & -1 & 1 & 4.5 & 2 & 10 & 2.1 \\
\hline 6 & 1 & 1 & -1 & -1 & 5.5 & 3 & 10 & 1.5 \\
\hline 7 & -1 & 1 & 1 & -1 & 4.5 & 3 & 20 & 1.5 \\
\hline 8 & -1 & -1 & 1 & 1 & 4.5 & 2 & 20 & 2.1 \\
\hline 9 & -1 & 1 & -1 & 1 & 4.5 & 3 & 10 & 2.1 \\
\hline 10 & 1 & -1 & 1 & -1 & 5.5 & 2 & 20 & 1.5 \\
\hline 11 & 1 & -1 & -1 & 1 & 5.5 & 2 & 10 & 2.1 \\
\hline 12 & 1 & 1 & 1 & -1 & 5.5 & 3 & 20 & 1.5 \\
\hline 13 & -1 & 1 & 1 & 1 & 4.5 & 3 & 20 & 2.1 \\
\hline 14 & 1 & -1 & 1 & 1 & 5.5 & 2 & 20 & 2.1 \\
\hline 15 & 1 & 1 & -1 & 1 & 5.5 & 3 & 10 & 2.1 \\
\hline 16 & 1 & 1 & 1 & 1 & 5.5 & 3 & 20 & 2.1 \\
\hline 17 & 1 & 0 & 0 & 0 & 5.5 & 2.5 & 15 & 1.8 \\
\hline 18 & -1 & 0 & 0 & 0 & 4.5 & 2.5 & 15 & 1.8 \\
\hline 19 & 0 & 1 & 0 & 0 & 5 & 3 & 15 & 1.8 \\
\hline 20 & 0 & -1 & 0 & 0 & 5 & 2 & 15 & 1.8 \\
\hline 21 & 0 & 0 & 1 & 0 & 5 & 2.5 & 20 & 1.8 \\
\hline 22 & 0 & 0 & -1 & 0 & 5 & 2.5 & 15 & 18 \\
\hline 23 & 0 & 0 & 0 & 1 & 5 & 2.5 & 20 & 2.1 \\
\hline 24 & 0 & 0 & 0 & -1 & 5 & 2.5 & 20 & 1.5 \\
\hline 25 & 0 & 0 & 0 & 0 & 5 & 2 & 20 & 1.8 \\
\hline 26 & 0 & 0 & 0 & 0 & 5 & 2 & 20 & 1.8 \\
\hline
\end{tabular}

1. $\mathrm{pH}: \mathrm{pH}$ value of flotation slurry adjusted with phosphoric acid;

2. CL: Dosage of FAS-40A as dolomite collector, $\mathrm{kg} / \mathrm{t}$;

3. IF: Froth height, $\mathrm{cm}$;

4. AR: Air flowrate, $1 / \mathrm{m}$. 


\subsubsection{Grinding Tests for Modified Packed Column Flotation}

Like in previous research ( $\mathrm{Gu}$ et al. 1999, Gu, 2002), particle size for flotation was set to pass $150 \mu \mathrm{m}$ (100 mesh) in order to achieve a high degree of liberation of phosphate from impurities. The method of grinding the dolomitic phosphate sample for the modified packed column flotation was described in Chapter 3. The grinding batch was 1000 grams and grinding time was 18 minutes. Five batches of each 1000 gram sample were combined and used for packed column flotation.

\subsubsection{Modified Packed Column Flotation Test Results}

As described in Chapter 3, five batches of each 1000 gram sample were combined and added into the conditioning tank and diluted to the desired solid percentage. It was conditioned with phosphoric acid to adjust $\mathrm{pH}$, then with fatty acid soap. The reagentized slurry was fed at about $3 \mathrm{ft}$. from the bottom of the modified packed column. Collector dosage, slurry $\mathrm{pH}$, air flowrate and froth height were four parameters to be investigated. Operation conditions of four parameters are presented in Table 4-2. At each experiment condition, the float and sink were sampled for a given time interval. The samples were filtered, dried, weighed and analyzed. The weight percentage, analysis and recoveries of the sink product and calculated selectivity index (SI) of separating dolomite from phosphate of each run are summarized in Table 4-4 and the full data sheet is presented in Appendix D. 


\subsubsection{Statistical Analysis Method}

The analysis of the modified packed column flotation test results was carried out using the commercial statistic software package JMP (SAS Institute, Inc.). In dolomite flotation process, a comprehensive factor should be considered as a response to justify the effectiveness of the separation, not just $\mathrm{MgO}$ content, $\mathrm{P}_{2} \mathrm{O}_{5}$ grade, or $\mathrm{P}_{2} \mathrm{O}_{5}$ recovery. For example, low $\mathrm{MgO}$ content in the product might be accompanied by low $\mathrm{P}_{2} \mathrm{O}_{5}$ recovery, and high $\mathrm{P}_{2} \mathrm{O}_{5}$ recovery might be associated with high $\mathrm{MgO}$ content. In defining the selectivity index, several factors were taken into consideration, including $\mathrm{P}_{2} \mathrm{O}_{5}$ grade, $\mathrm{P}_{2} \mathrm{O}_{5}$ and $\mathrm{MgO}$ recoveries. Therefore, the selectivity index (SI) was chosen as a comprehensive response to evaluate the process.

In this study, the selectivity index (SI) of separating dolomite from phosphate, SI, was used as the response of the experiment input in JMP program. In running JMP program, "Stepwise" analysis option was selected. The stepwise regression procedure allowed selecting probabilities ( $\mathrm{p}$-value) for adding or deleting terms in the model. The p-value was chosen to be 0.10 for statistical analysis in this study. The program will automatically create a model using "forward" and "backward" procedures to select significant parameters and delete insignificant ones.

\subsubsection{Statistical Analysis Results}

The output of JMP includes the estimated coefficients, t-ratios and p-values, standard 
deviations, $\mathrm{R}^{2}$ as well as an analysis of variance (ANOVA) table with lack-of-fit information. The estimated coefficients, standard errors and t-ratios are presented in Table 4-5, and sum of squares and F-ratios are presented in Table 4-6. Table 4-7 shows the analysis of variance (ANOVA).

From the output of the JMP program as shown in Tables 4-6 and 4-7, DF is the degree of freedom, SS is the sum of squares and MS is the mean square. The f-statistic, also known as the F-ratio, is a measure for the strength of the regression. The F-ratios are calculated by comparing the model mean square (MSR) with the error mean square (MSE), $\quad \mathrm{F}=\mathrm{MSR} / \mathrm{MSE}=(\mathrm{SSR} / 1) /\left(s_{e}^{2}\right)$. Here $\mathrm{MSR}$ is the predicted mean-squared-anomaly and MSE is the mean-squared-error. A strong relationship between responses and independant parameters gives a high F-ratio. The statistic analysis data in Table 4-5 shows that statistically significant factors include flotation $\mathrm{pH}$, collector dosage, air flow rate and interactions of $\mathrm{pH}$ with collector, $\mathrm{pH}$ with air flow rate and collector with air flow rate. It is noted that froth height is not a significant factor between 15 and $20 \mathrm{~cm}$ in this study. This is probably because a sparger is used to generate fine bubbles, which produce a relatively stable and well mineralized froth layer. The change of froth height parameter does not significantly affect the amount of the mineral particles attached on the bubbles or the quantity of the froth overflow at the same reagent usages and airflow rate. From this point of view, the installation of a sparger should be beneficial for flotation separation, at least for low grade ores. Based on the statistical analysis results, the reduced model in terms of the coded factor levels is: 
$\mathrm{Y}=32.48+1.33 \times \mathrm{pH}+4.10 \times$ Collector $+1.64 \times$ Air $+1.19 \times \mathrm{pH} \times$ Collector

$-1.20 \times \mathrm{pH} \times$ air+1.03 $\times$ collector $\times$ air

By using the coding algorithm $\left[\mathrm{X}_{\mathrm{i}}{ }^{*}=2\left(\left(\mathrm{X}_{\mathrm{i}}\right.\right.\right.$-midpoint $\left.\mathrm{m}_{\mathrm{i}}\right) /$ range $\left.\left._{\mathrm{i}}\right)\right]$, the model in terms of actual factor levels rather than the coded factor levels is:

$\mathrm{Y}=7.24+5.16 \times \mathrm{pH}-27.96 \times$ Collector $+28.27 \times$ Air $+4.76 \times \mathrm{pH} \times$ Collector

$-7.99 \times p H \times a i r+6.84 \times$ collector $\times$ air

The coefficient of determination $\left(\mathrm{R}^{2}\right)$ and adjusted coefficient of determination $\left(\mathrm{R}^{2}\right.$ adj.) are other measures for expressing the goodness-of-fit of the regression model. $R^{2}$ is 1 for a perfect regression and zero for a completely useless fit (no correlation between responses and independent parameters). In this study, the coefficient of determination $\left(\mathrm{R}^{2}\right)$ and adjusted coefficient of determination $\left(\mathrm{R}^{2}\right.$ adj. $)$ are 0.81 and 0.75 respectively, which indicates relatively good fit of the model achieved. A comparison of observed responses and those predicted by the reduced model are shown in Table 4-8 and Fig. 4-46. 
Table 4-4 Results of modified packed column flotation

\begin{tabular}{|c|c|c|c|c|c|c|c|c|c|c|c|c|c|c|}
\hline \multirow{2}{*}{ Run } & \multicolumn{4}{|c|}{ Codec } & \multicolumn{4}{|c|}{ Natura } & \multirow{2}{*}{$\%$} & \multicolumn{2}{|c|}{ Grade, $\%$} & \multicolumn{2}{|c|}{ very, \% } & \multirow{2}{*}{ SI } \\
\hline & $\mathrm{pH}$ & CL & IT & & $\mathrm{pH}$ & 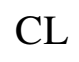 & IF & AR & & 3 & & & & \\
\hline 1 & -1 & & & & & & & & 6.60 & 96 & & & & 3.4 \\
\hline 2 & 1 & & & & & & & & & 36 & & & & $2 \pi$ \\
\hline 3 & 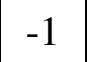 & & & -1 & & & & 5 & I & .50 & 6 & 4.19 & 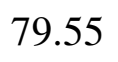 & $x$ \\
\hline 4 & 1 & 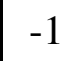 & & -1 & & & & 1.5 & .20 & 00 & & 97.02 & 0 & 706 \\
\hline 5 & -1 & -1 & & & & & & 2.1 & & 5.79 & & & & 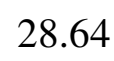 \\
\hline 6 & 1 & & - & -1 & & & & .5 & .79 & 88 & 0 & 0.78 & .48 & 6.9 \\
\hline 7 & 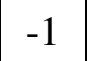 & 1 & 1 & 1 & & & & 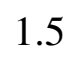 & 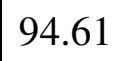 & 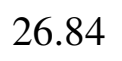 & 3 & &. & . \\
\hline 8 & 1 & 1 & & & & & & 2.1 & .00 & 1.17 & 12 & 2 & 2.52 & 1.3 \\
\hline 9 & -1 & 1 & -1 & 1 & & 3 & & 2.1 & .86 & 5.70 & 5 & 33 & 3.12 & 8.5 \\
\hline 10 & 1 & -1 & 1 & -1 & & 2 & 2 & .5 & 77 & 0 & 7 & & .00 & 49 \\
\hline 11 & 1 & & & & & & & & 9030 & & & & & 2827 \\
\hline 12 & 1 & 1 & 1 & -1 & & 3 & & 1.5 & .84 & .88 & .11 & & & \\
\hline 13 & -1 & 1 & 1 & & & 3 & & 2.1 & .10 & 7.00 & 18 & .83 & 5.99 & 36.61 \\
\hline 14 & 1 & -1 & 1 & & & 2 & & 1 & 2.89 & 38 & 1.29 & 8 & 4.82 & 25.2 \\
\hline 12 & 1 & 1 & -1 & & & 2 & & & 86.89 & 26.99 & 0.95 & & 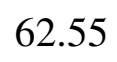 & 41.81 \\
\hline 16 & 1 & & & & & & & & (1) & & 70 & & & 9.9 \\
\hline 17 & 1 & 0 & ( & 0 & & & & 1 & .35 & 5.72 & 1.03 & 92.77 & 2.10 & 37.7 \\
\hline 18 & -1 & 0 & 0 & 0 & 4.5 & 2.5 & 1. & 1.8 & .49 & .71 & 14 & 55 & 8.04 & 333 \\
\hline 19 & 0 & 1 & 0 & & & & & & 0.99 & & 1.12 & & 73.82 & 35 \\
\hline 20 & 0 & 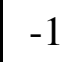 & 0 & 0 & & & & & נוס. & 0.12 & 1.10 & T. & & 2.1 \\
\hline 21 & 0 & 0 & 1 & 0 & & & & 1.8 & 2.78 & 6.81 & 1.22 & 94.17 & 80.49 & $30.9^{\prime}$ \\
\hline 22 & 0 & c & -1 & 0 & & & 1. & 18 & 1.71 & 34 & 1.14 & 93.32 & 77.02 & 33.6 \\
\hline 23 & 0 & 0 & 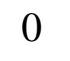 & 1 & J & & & 2.1 & 91.39 & 27.00 & 1.16 & 00 & 76.54 & 2 \\
\hline 24 & 0 & 0 & 0 & -1 & 5 & 2.5 & & $1 .$. & 92.89 & 6.91 & 1.14 & 94.44 & 9.42 & 32.01 \\
\hline 25 & 0 & 0 & 0 & 0 & 5 & 2 & & 1. & 93.78 & 6.70 & 1.25 & 95.23 & 82.12 & 30.43 \\
\hline 26 & 0 & U & 0 & 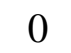 & 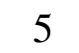 & 2 & & .8 & 98 & 81 & 1.20 & 94.58 & 80.35 & 31.6 \\
\hline
\end{tabular}


Table 4-5 Estimated coefficients, standard deviation, t-ratios and p-values

\begin{tabular}{|c|c|c|c|c|}
\hline Term & Estimate & Std. Error & t-ratio & Prob $>|\mathrm{t}|$ \\
\hline Intercept & 32.49 & 0.46 & 70.90 & $<0.0001$ \\
\hline $\mathrm{pH}$ & 1.33 & 0.55 & 2.41 & 0.0260 \\
\hline $\mathrm{CL}$ & 4.10 & 0.55 & 7.44 & $<0.0001$ \\
\hline $\mathrm{AR}$ & 1.64 & 0.55 & 2.98 & 0.0076 \\
\hline $\mathrm{pH} \times \mathrm{CL}$ & 1.19 & 0.58 & 2.03 & 0.0565 \\
\hline $\mathrm{pH} \times \mathrm{AR}$ & -1.20 & 0.58 & -2.06 & 0.0537 \\
\hline $\mathrm{CL} \times \mathrm{AR}$ & 1.03 & 0.58 & 1.77 & 0.0936 \\
\hline
\end{tabular}

Table 4-6 Sum of squares, F-ratios and p-values

\begin{tabular}{|c|c|c|c|c|}
\hline Term & DF $^{*}$ & SS $^{* *}$ & F-ratio & Prob $>$ F \\
\hline $\mathrm{pH}$ & 1 & 31.81 & 5.83 & 0.0260 \\
\hline $\mathrm{CL}$ & 1 & 302.33 & 55.38 & $<0.0001$ \\
\hline $\mathrm{AR}$ & 1 & 48.64 & 8.91 & 0.0076 \\
\hline $\mathrm{pH} \times \mathrm{CL}$ & 1 & 22.52 & 4.12 & 0.0565 \\
\hline $\mathrm{pH} \times \mathrm{AR}$ & 1 & 23.09 & 4.22 & 0.0537 \\
\hline $\mathrm{CL} \times \mathrm{AR}$ & 1 & 17.02 & 3.12 & 0.0936 \\
\hline
\end{tabular}

* Degree of freedom;

** Sum of squares.

Table 4-7 ANOVA table with selectivity index as responses

\begin{tabular}{|c|c|c|c|c|}
\hline Source & DF & SS & MS & F-ratio \\
\hline Model & 6 & 445.41 & 74.23 & 13.5974 \\
\hline Error & 19 & 103.73 & 5.46 & Prob > F \\
\hline Total & 25 & 549.14 & & $<.0001$ \\
\hline
\end{tabular}


Table 4-8 Experimental central composite design matrix showing observed and

predicted responses

\begin{tabular}{|c|c|c|c|c|c|c|c|c|c|c|}
\hline \multirow{2}{*}{ Run } & \multicolumn{4}{|c|}{ Coded conditions } & \multicolumn{4}{|c|}{ Natural conditions } & \multirow{2}{*}{$\begin{array}{c}\text { Observed } \\
\text { SI }\end{array}$} & \multirow{2}{*}{$\begin{array}{c}\text { Predicted } \\
\text { SI }\end{array}$} \\
\hline & $\mathrm{pH}$ & $\mathrm{CL}$ & IF & $\mathrm{AR}$ & $\mathrm{pH}$ & $\mathrm{CL}$ & IF & $\mathrm{AR}$ & & \\
\hline 1 & -1 & -1 & -1 & -1 & 4.5 & 2 & 10 & 3.5 & 23.41 & 26.43 \\
\hline 2 & 1 & -1 & -1 & -1 & 5.5 & 2 & 10 & 3.5 & 32.22 & 29.11 \\
\hline 3 & -1 & 1 & -1 & -1 & 4.5 & 3 & 10 & 3.5 & 31.85 & 30.19 \\
\hline 4 & -1 & -1 & 1 & -1 & 4.5 & 2 & 20 & 3.5 & 27.05 & 26.43 \\
\hline 5 & -1 & -1 & -1 & 1 & 4.5 & 2 & 10 & 4.5 & 28.64 & 30.05 \\
\hline 6 & 1 & 1 & -1 & -1 & 5.5 & 3 & 10 & 3.5 & 36.95 & 37.63 \\
\hline 7 & -1 & 1 & 1 & -1 & 4.5 & 3 & 20 & 3.5 & 29.05 & 30.19 \\
\hline 8 & -1 & -1 & 1 & 1 & 4.5 & 2 & 20 & 4.5 & 31.35 & 30.05 \\
\hline 9 & -1 & 1 & -1 & 1 & 4.5 & 3 & 10 & 4.5 & 38.52 & 37.93 \\
\hline 10 & 1 & -1 & 1 & -1 & 5.5 & 2 & 20 & 3.5 & 24.95 & 29.11 \\
\hline 11 & 1 & -1 & -1 & 1 & 5.5 & 2 & 10 & 4.5 & 28.27 & 27.93 \\
\hline 12 & 1 & 1 & 1 & -1 & 5.5 & 3 & 20 & 3.5 & 36.6 & 37.63 \\
\hline 13 & -1 & 1 & 1 & 1 & 4.5 & 3 & 20 & 4.5 & 36.61 & 37.93 \\
\hline 14 & 1 & -1 & 1 & 1 & 5.5 & 2 & 20 & 4.5 & 25.27 & 27.93 \\
\hline 15 & 1 & 1 & -1 & 1 & 5.5 & 3 & 10 & 4.5 & 41.81 & 40.57 \\
\hline 16 & 1 & 1 & 1 & 1 & 5.5 & 3 & 20 & 4.5 & 39.91 & 40.57 \\
\hline 17 & 1 & 0 & 0 & 0 & 5.5 & 2.5 & 15 & 4 & 37.73 & 33.81 \\
\hline 18 & -1 & 0 & 0 & 0 & 4.5 & 2.5 & 15 & 4 & 33.3 & 31.15 \\
\hline 19 & 0 & 1 & 0 & 0 & 5 & 3 & 15 & 4 & 35.82 & 36.58 \\
\hline 20 & 0 & -1 & 0 & 0 & 5 & 2 & 15 & 4 & 32.19 & 28.38 \\
\hline 21 & 0 & 0 & 1 & 0 & 5 & 2.5 & 20 & 4 & 30.97 & 32.48 \\
\hline 22 & 0 & 0 & -1 & 0 & 5 & 2.5 & 15 & 4 & 33.68 & 32.48 \\
\hline 23 & 0 & 0 & 0 & 1 & 5 & 2.5 & 20 & 4.5 & 33.86 & 34.12 \\
\hline 24 & 0 & 0 & 0 & -1 & 5 & 2.5 & 20 & 3.5 & 32.57 & 30.84 \\
\hline 25 & 0 & 0 & 0 & 0 & 5 & 2 & 20 & 4 & 30.43 & 28.38 \\
\hline 26 & 0 & 0 & 0 & 0 & 5 & 2 & 20 & 4 & 31.66 & 28.38 \\
\hline
\end{tabular}




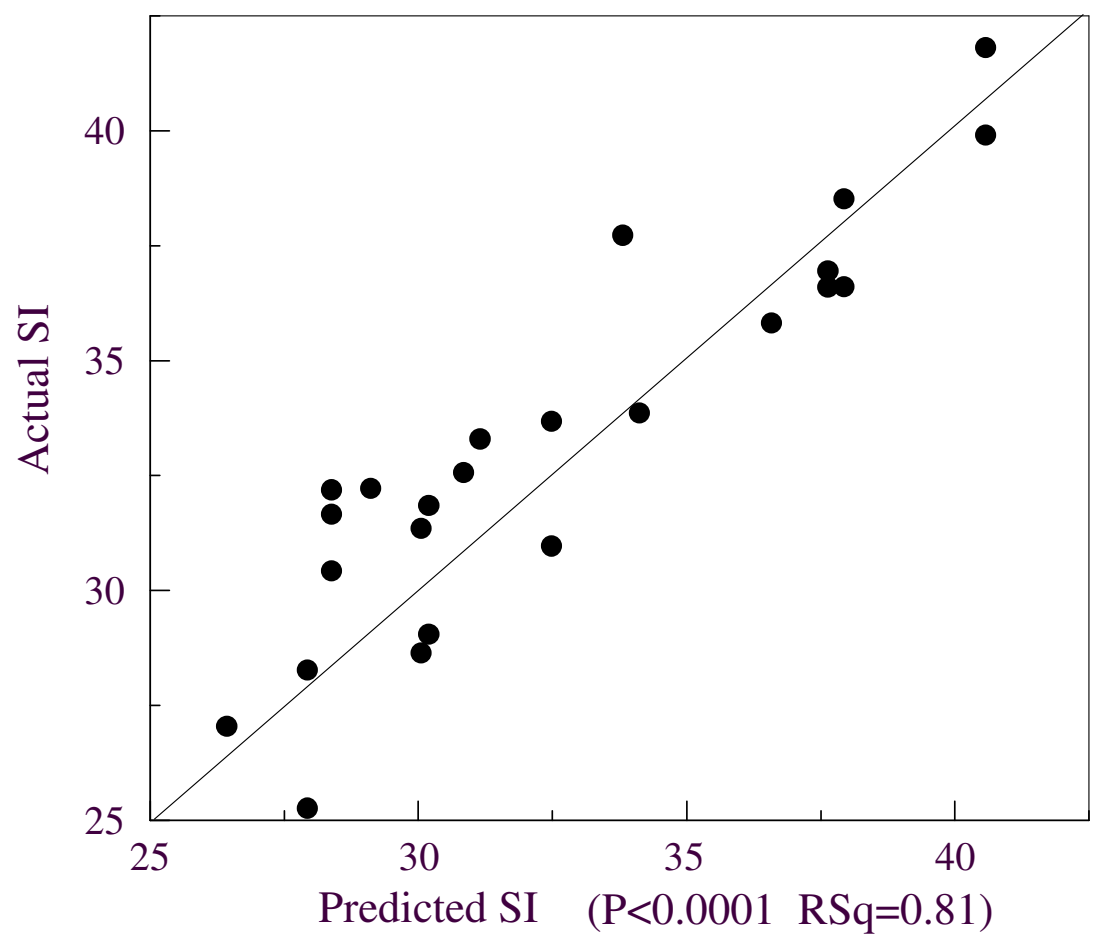

Fig. 4-46 Comparison of the observed responses and predicted responses with reduced model

From Eqs. 4-6 and 4-7, it can be observed that there are some interactions between $\mathrm{pH}$ and collector dosage, $\mathrm{pH}$ and air flow rate, and air flow rate and collector dosage. Interactive effects of different operation parameters are plotted in Figs. 4-47, 4-48 and 4-49. Those figures indicate that the highest separation selectivity index can be obtained at high values of $\mathrm{pH}$, collector dosage and air flow rate. The best separation performance is achieved at around $\mathrm{pH} 5.5$, which is coincident with the conclusions made by other investigators (Smani, et al. 1975, El-Shall, 2004, Anazia and Hanna, 1988, Abramov et al., 
1993, Elgillani and Abouzeid, 1993, El-Shall, et al., 1996, Prasad et al., 2000, Gu et al. 1999, Peng and $\mathrm{Gu}, 2005)$. Further increase of $\mathrm{pH}$ will reduce the effect of phosphate depression and deteriorate the separation process by increasing $\mathrm{P}_{2} \mathrm{O}_{5}$ loss into the float. This leads to low separation selectivity which has been demonstrated in stirred-tank cell tests in this study and also reported elsewhere $(\mathrm{Gu}, 2002)$. It is not surprising that the best separation selectivity index is observed at the collector dosage of $3.0 \mathrm{~kg} / \mathrm{t}$ of feed in this set of column flotation tests. At this collector dosage, more dolomite can be rejected into the overflow. From the definition of the selectivity index, it can be seen that the amount of $\mathrm{MgO}$ removed from the ore is a significant factor in the separation selectivity. Increasing collector dosage will further reduce $\mathrm{MgO}$ content in the underflow phosphate concentrate, but also at the cost of high $\mathrm{P}_{2} \mathrm{O}_{5}$ loss into the overflow. Comparing with the stirred-tank cell test results, it is noticed that column flotation consumes more collector, about two times that of stirred-tank cell flotation.

At low $\mathrm{pH}$, the selectivity index increases sharply with the increase of air flow rate as shown in Fig. 4-48. With further increase of the flotation $\mathrm{pH}$, the increase of the magnitude of the selectivity index of dolomite flotation (SI) becomes smaller. At low collector dosage, the air flow rate has little effect on the selectivity index of the separation. With the increase of the collector dosage, high air flow rate can improve the selectivity index of dolomite flotation (SI) as illustrated in Fig. 4-49. 


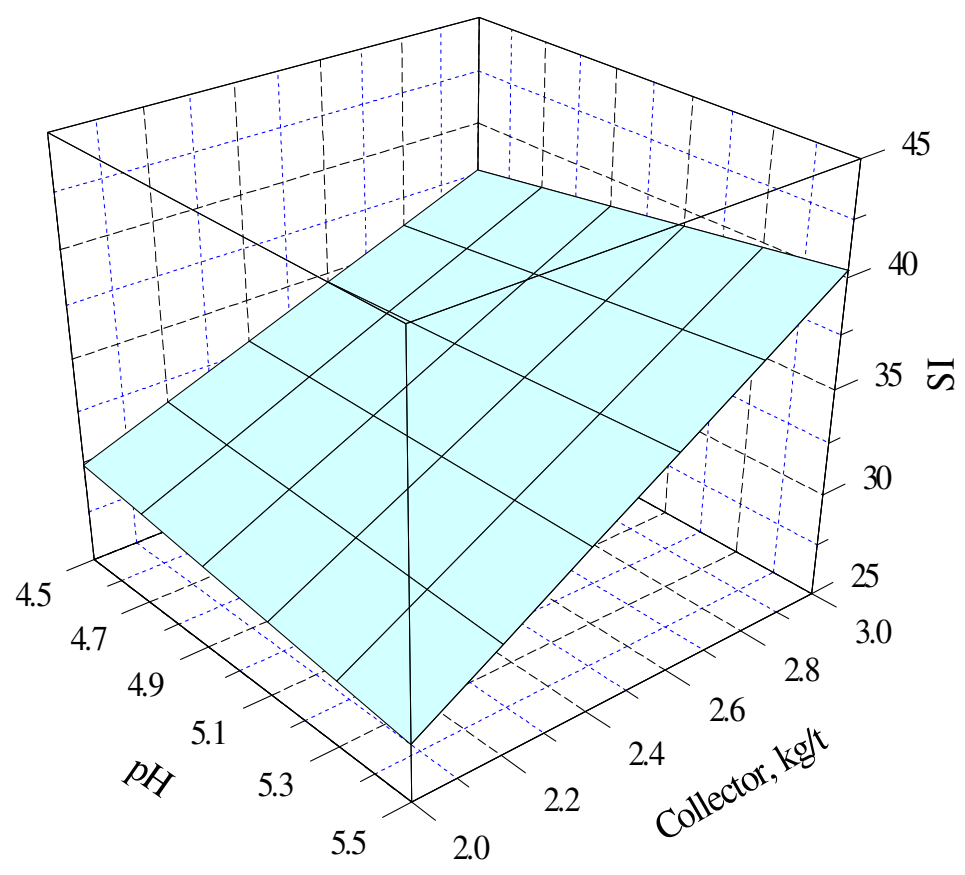

Fig. 4-47 Interactive effect of $\mathrm{pH}$ and collector dosages with the selectivity index as

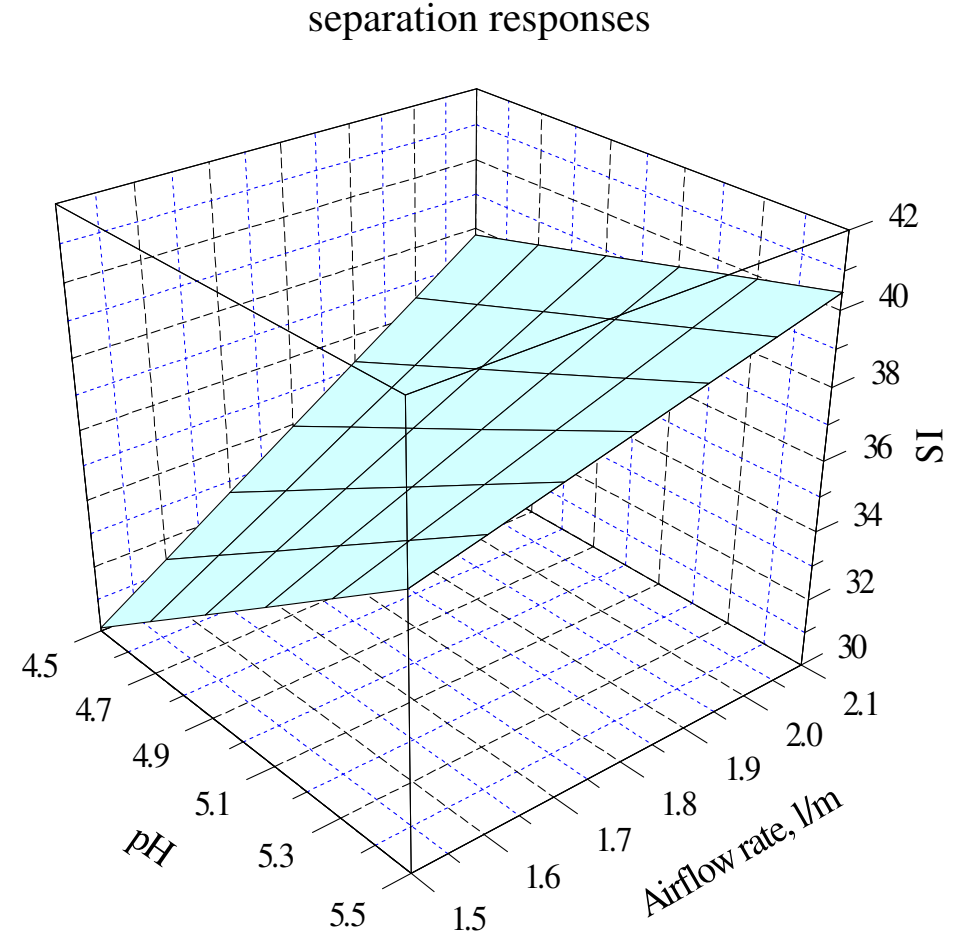

Fig. 4-48 Interactive effect of $\mathrm{pH}$ and air flow rate with the selectivity index as separation responses 


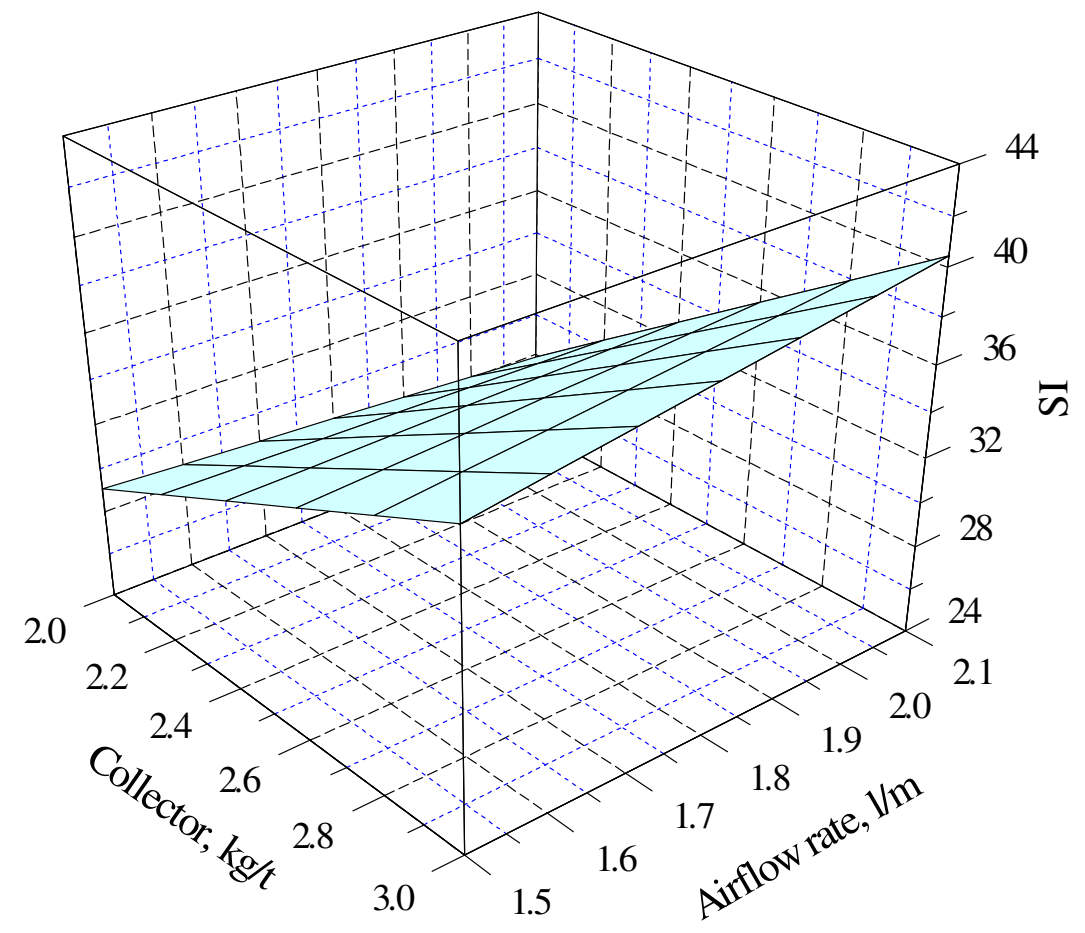

Fig. 4-49 Interactive effect of air flow rate and collector dosages with the selectivity index as separation responses

\subsubsection{Modified Packed Column Flotation of Dolomitic Phosphate Ore with Mixture of FAS-40A and DSS1 as Collector}

In order to further confirm the effectiveness of surfactant DSS1 on dolomite flotation in processing dolomitic phosphate ores, flotation tests on 2 in. diameter modified packed column were carried out with the flotation conditions optimized by central composite design (CCD) except that $10 \%$ of DSS1 was used with FAS-40A as mixture collector. Two sets of tests were conducted under the same operation condition with the results summarized in Table 4-9. The test results indicate that the surfactant DSS1 can significantly improve dolomite flotation of dolomitic phosphate ores in modified packed 
column flotation. Without using any surfactant, $37.45 \% \mathrm{MgO}$ was removed at $11.2 \%$ $\mathrm{P}_{2} \mathrm{O}_{5}$ loss. If $10 \%$ of surfactant DSS1 was mixed with FAS-40A as collector, the $\mathrm{MgO}$ recovery in the overflow was increased from $37.45 \%$ to over $48 \%$. It means that at least $10 \%$ more $\mathrm{MgO}$ could be removed. The $\mathrm{P}_{2} \mathrm{O}_{5}$ loss was still the same, even slightly lower than the results with FAS-40A collector alone. 
Table 4-9 Packed column test results using FAS-40A collector and surfactant DSS1

\begin{tabular}{|c|c|c|c|c|c|c|c|c|}
\hline \multirow{2}{*}{ Conditions* } & \multirow{2}{*}{\multicolumn{2}{|c|}{ Product }} & \multirow{2}{*}{ Wt. $\%$} & \multicolumn{2}{|c|}{ Grade, $\%$} & \multicolumn{2}{|c|}{ Recovery, \% } & \multirow{2}{*}{ SI } \\
\hline & & & & $\mathrm{P}_{2} \mathrm{O}_{5}$ & $\mathrm{MgO}$ & $\mathrm{P}_{2} \mathrm{O}_{5}$ & $\mathrm{MgO}$ & \\
\hline \multirow{2}{*}{ FAS-40A: $3.0 \mathrm{~kg} / \mathrm{t}$} & \multicolumn{2}{|c|}{ Float } & 13.11 & 22.56 & 3.77 & 11.20 & 37.45 & \multirow{3}{*}{41.8} \\
\hline & \multicolumn{2}{|c|}{ Sink } & 86.89 & 26.99 & 0.95 & 88.80 & 62.55 & \\
\hline DSS1: $\quad 0 \mathrm{~kg} / \mathrm{t}$ & \multicolumn{2}{|c|}{ Feed } & 100.0 & 26.41 & 1.32 & 100.0 & 100.0 & \\
\hline \multirow{6}{*}{ FAS-40A: $3.0 \mathrm{~kg} / \mathrm{t}$} & \multirow{3}{*}{ Test 1} & Float & 14.21 & 19.85 & 4.58 & 10.80 & 48.36 & \multirow{3}{*}{50.27} \\
\hline & & Sink & 85.79 & 27.15 & 0.81 & 89.20 & 51.64 & \\
\hline & & Feed & 100.00 & 26.11 & 1.35 & 100.00 & 100.00 & \\
\hline & \multirow{3}{*}{ Test 2} & Float & 14.45 & 20.22 & 4.46 & 11.14 & 48.81 & \multirow{3}{*}{50.34} \\
\hline & & Sink & 85.55 & 27.25 & 0.79 & 88.86 & 51.19 & \\
\hline & & Feed & 100.00 & 26.23 & 1.32 & 100.00 & 100.00 & \\
\hline
\end{tabular}

Other operation conditions: $\mathrm{pH} 5.4$, Airflow rate $2.1 \mathrm{1} / \mathrm{m}$, Froth height $20 \mathrm{~cm}$.

\subsubsection{Correlation between Grade and Recovery}

The relationships between $\mathrm{P}_{2} \mathrm{O}_{5}$ recovery and $\mathrm{P}_{2} \mathrm{O}_{5}$ grade, $\mathrm{MgO}$ grade and $\mathrm{P}_{2} \mathrm{O}_{5}$ grade as well as $\mathrm{P}_{2} \mathrm{O}_{5}$ recovery and $\mathrm{MgO}$ grade in the underflow phosphate concentrate of dolomite flotation are plotted in Figs. 4-50, 4-51 and 4-52 respectively. Fig. 4-50 illustrates that $\mathrm{P}_{2} \mathrm{O}_{5}$ recovery decreases with $\mathrm{P}_{2} \mathrm{O}_{5}$ grade increase. When dolomite particles are floated, some of phosphate particles are also floated with dolomite particles 
due to the entrapment of phosphate particles in froth, imperfect selectivity in the separation, interlocked particles, etc. Generally, increasing the amount of the float material can improve the $\mathrm{P}_{2} \mathrm{O}_{5}$ grade in the sink product. Such $\mathrm{P}_{2} \mathrm{O}_{5}$ grade improvement in the sink is achieved at the expense of $\mathrm{P}_{2} \mathrm{O}_{5}$ loss into the float. It is noted that when FAS-40A was used with $10 \%$ DSS1 as collector for dolomite flotation, the rougher phosphate concentrate with higher $\mathrm{P}_{2} \mathrm{O}_{5}$ grade was obtained at the same $\mathrm{P}_{2} \mathrm{O}_{5}$ recovery. The use of DSS1 with FAS-40A as dolomite flotation collector can improve both the collecting ability of the collector and the selectivity of dolomite flotation. Due to the increase of the yield of dolomite flotation with more $\mathrm{MgO}$ and less $\mathrm{P}_{2} \mathrm{O}_{5}$, the underflow with high $\mathrm{P}_{2} \mathrm{O}_{5}$ grade can be obtained. 


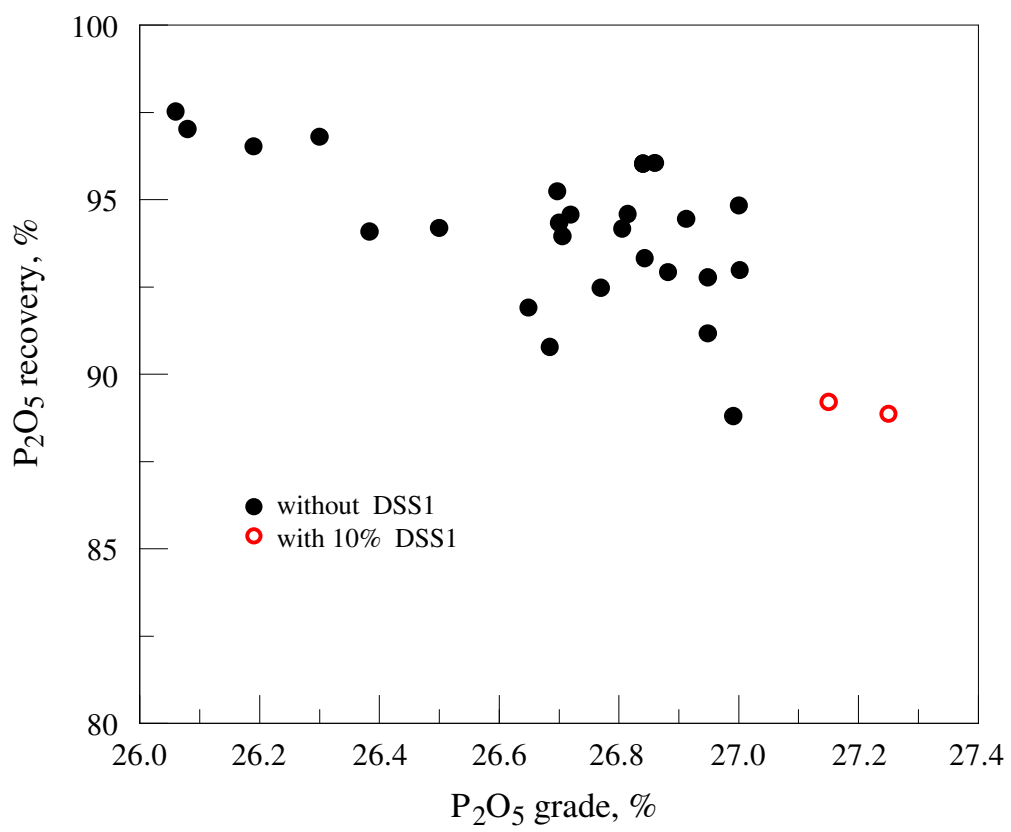

Fig. 4-50 Relationship between $\mathrm{P}_{2} \mathrm{O}_{5}$ grade and $\mathrm{P}_{2} \mathrm{O}_{5}$ recovery in the sink product of dolomite flotation

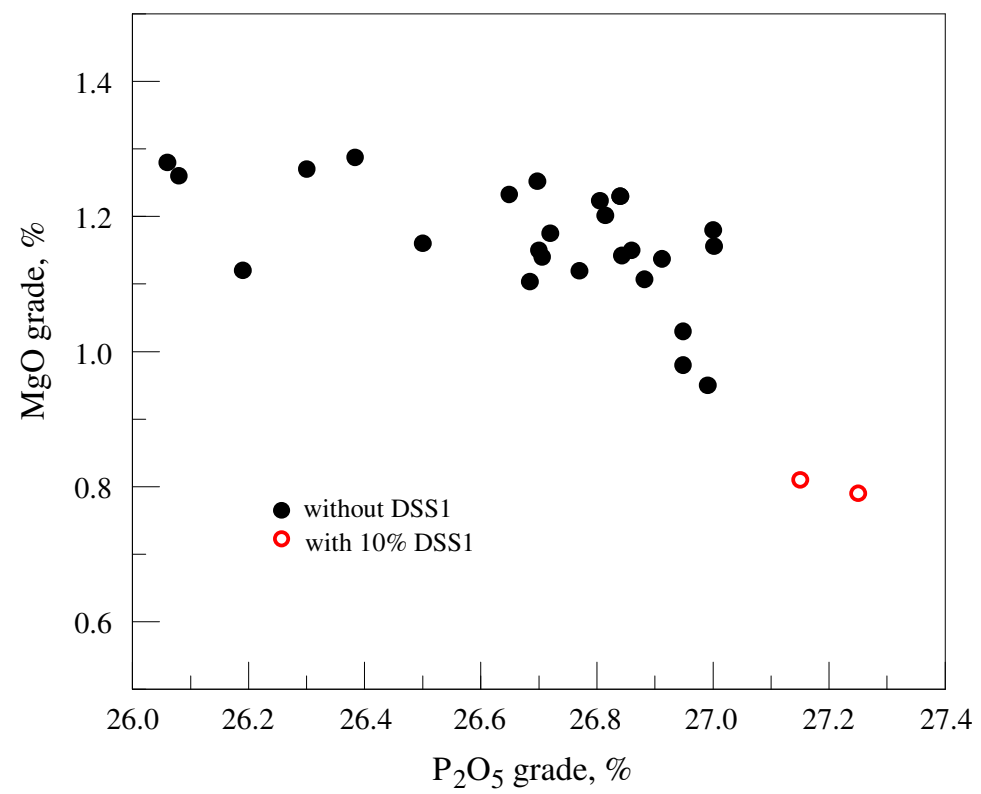

Fig. 4-51 Relationship between $\mathrm{P}_{2} \mathrm{O}_{5}$ and $\mathrm{MgO}$ grade in the sink product of dolomite flotation 
Fig. 4-51 presents the correlation between $\mathrm{MgO}$ and $\mathrm{P}_{2} \mathrm{O}_{5}$ grade in the underflow of the dolomite flotation using modified packed flotation column. The trend of the correlation figure shows that $\mathrm{P}_{2} \mathrm{O}_{5}$ grade increases with the decrease of the $\mathrm{MgO}$ content in the underflow product. Low $\mathrm{MgO}$ content in the underflow product means that more dolomite is reported to the float. Therefore, the $\mathrm{P}_{2} \mathrm{O}_{5}$ grade was improved because less dolomite was left in the underflow. From this figure, it can be easily seen that when FAS-40A was used with surfactant DSS1, the rougher phosphate concentrate contained highest $\mathrm{P}_{2} \mathrm{O}_{5}$ grade and lowest $\mathrm{MgO}$ content compared with other operation conditions. Fig. 4-52 indicates that $\mathrm{P}_{2} \mathrm{O}_{5}$ recovery decreases with the decrease of $\mathrm{MgO}$ content. It can also be found that using surfactant DSS1 will improve dolomite flotation results.

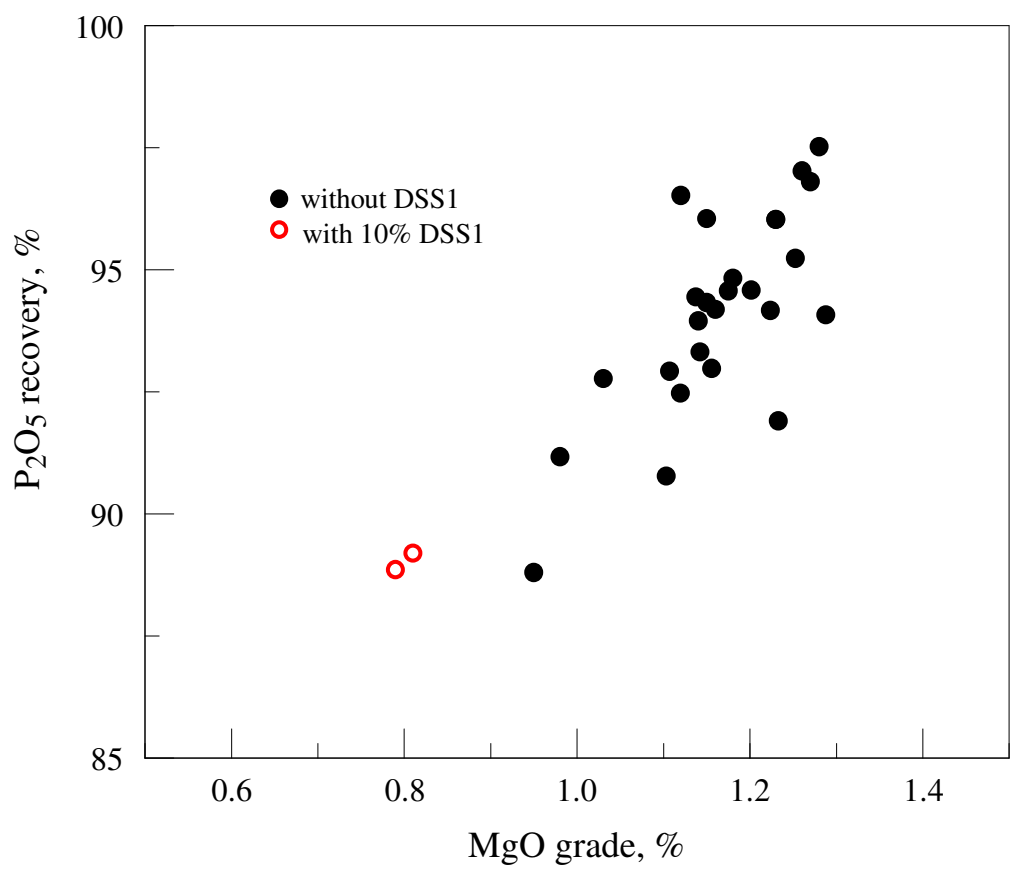

Fig. 4-52 Relationship between $\mathrm{MgO}$ grade and $\mathrm{P}_{2} \mathrm{O}_{5}$ recovery in the sink product of dolomite flotation 


\subsubsection{Amine Flotation to Remove Silica Impurity}

Under the operation conditions of $\mathrm{pH} 5.5$, collector dosage $3.0 \mathrm{~kg} / \mathrm{t}$ of feed, air flow rate $2.1 \mathrm{l} / \mathrm{min}$. and froth height $20 \mathrm{~cm}$, the underflow of the modified packed column after dolomite flotation was collected for silica amine flotation. The collected sample was first sized at $38 \mu \mathrm{m}$ (400 mesh). Applying double reverse flotation process, the plus $38 \mu \mathrm{m}$ fraction was conditioned with fatty acid amine as collector and kerosene as collector aid. After conditioning, the slurry was subjected to silica flotation in Denver machine with 1.2 liter cell to reject silica into the float tailings. The underflow of silica flotation was combined with the minus $38 \mu \mathrm{m}$ fines to form a composite phosphate concentrate. Two sets of column flotation tests were carried out using FAS-40A collector with surfactant DSS1 and the underflow of the column was collected for silica flotation tests for the purpose of comparing the difference of the test results with and without surfactant. The flowsheet and material balance are given in Fig. 4-53 and Table 4-10. It can be seen that the final composite phosphate concentrate contains $30.35 \% \mathrm{P}_{2} \mathrm{O}_{5}, 1.03 \% \mathrm{MgO}$ and $4.88 \%$ acid insoluble. The overall $\mathrm{P}_{2} \mathrm{O}_{5}$ recovery is $87.14 \%$. When surfactant DSS1 was used with FAS-40A as dolomite collector, a composite phosphate product containing $31.18 \%$ $\mathrm{P}_{2} \mathrm{O}_{5}$ and $0.92 \% \mathrm{MgO}$ was obtained at $88.09 \% \mathrm{P}_{2} \mathrm{O}_{5}$ recovery. The test results indicate that surfactant DSS1 can significantly improve the separation selectivity of dolomite flotation by removing more dolomite into float as tailings and reducing the $\mathrm{MgO}$ content in the final phosphate concentrate. 


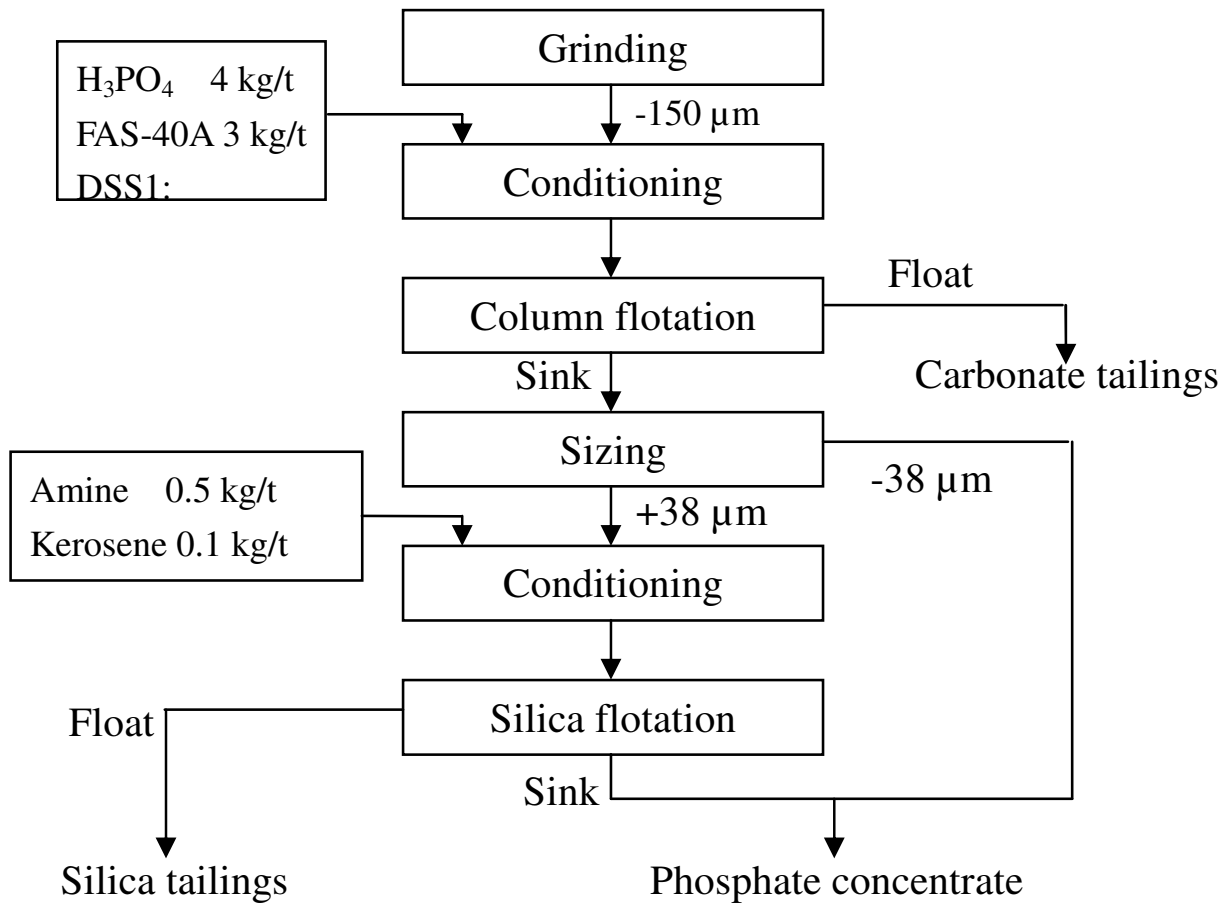

Fig. 4-53 Flotation flowsheet of dolomite flotation with modified packed column and silica flotation with mechanic cell 
Table 4-10 Material balance of dolomite flotation followed by silica amine flotation*

\begin{tabular}{|c|c|c|c|c|c|c|c|c|}
\hline \multirow{2}{*}{ Condition } & \multirow{2}{*}{ roduct } & \multirow{2}{*}{ Wt. \% } & \multicolumn{3}{|c|}{ Grade, \% } & \multicolumn{3}{|c|}{ Recovery, \% } \\
\hline & & & $\mathrm{P}_{2} \mathrm{O}_{5}$ & $\mathrm{Mg}$ & A.I. & $\mathrm{P}_{2} \mathrm{O}_{5}$ & $\mathrm{MgO}$ & A.I. \\
\hline \multirow[t]{2}{*}{ Without } & Dolomite float & 13.54 & 22.43 & 4.01 & 3.47 & 11.61 & 41.03 & 3.28 \\
\hline & Silica float & 11.35 & 2.88 & 0.07 & 89.63 & 1.25 & 0.60 & 71.10 \\
\hline DSS1 for & Sink & 55.23 & 30.85 & 0.82 & 3.80 & 65.13 & 38.39 & 14.67 \\
\hline dolomite & $-38 \mu \mathrm{m}$ fines & 19.88 & 28.97 & 1.33 & 8.14 & 22.01 & 19.88 & 14.95 \\
\hline \multirow{2}{*}{ flotation } & Composite con & 75.11 & 30.35 & 1.03 & 4.88 & 87.14 & 58.37 & 25.88 \\
\hline & Head & 100.0 & 26.16 & 1.32 & 14.36 & 100.0 & 100.0 & 100.0 \\
\hline \multirow[t]{2}{*}{ With $10 \%$} & Dolomite float & 14.21 & 20.22 & 4.58 & 2.94 & 10.87 & 48.40 & 2.98 \\
\hline & Silica float & 11.14 & 2.45 & 0.09 & 91.12 & 1.03 & 0.75 & 72.52 \\
\hline DSS1 for & Sink & 56.29 & 31.68 & 0.83 & 3.41 & 67.49 & 34.74 & 13.71 \\
\hline \multirow[t]{2}{*}{ dolomite } & $-38 \mu \mathrm{m}$ fines & 18.36 & 29.66 & 1.18 & 8.22 & 20.61 & 16.11 & 10.78 \\
\hline & Composite conc. & 74.65 & 31.18 & 0.92 & 4.59 & 88.09 & 50.86 & 24.50 \\
\hline flotation & Head & 100.00 & 26.42 & 1.34 & 14.00 & 100.00 & 100.00 & 100.00 \\
\hline
\end{tabular}

* All other operation conditions are same except with and without DSS1 for dolomite flotation. 


\section{CHAPTER 5 CONCLUSIONS}

Hallimond cell flotation, stirrer-tank cell flotation as well as modified packed column flotation of dolomitic phosphate ores demonstrated that the selected surfactants could be used with fatty acid type collectors for dolomite flotation by increasing collecting ability and improving separation selectivity. From experiment data, the following conclusions can be made:

1. The frothability of dolomite collector FAS-40A increases with the increase of collector dosage and aeration rate. Addition of surfactants into FAS-40A can, to some extent, improve the frothing capability of the collector. The improvement is affected by the percentage of the surfactant added in FAS-40A. Among three surfactants selected in this study, DSS1 has the most significant effect on the frothability of FAS-40A. With DSS1, frothability of FAS-40A shows a sharp increase after DSS1 proportion is raised from $7.5 \%$ to $10 \%$. The utilization of surfactants can also increase the stability of the froth layer in the order of DSS1 > DP $>$ TW $>$ FAS-40A only.

2. Hallimond cell flotation test results show that dolomite flotation recovery increases with the increase of collector dosage, and addition of 10\% DSS1 to FAS-40A as collector can produce the best recovery in dolomite flotation. Using surfactant DP can improve the dolomite flotation recovery of relatively coarse particle size such as 
minus 0.3 plus $0.25 \mathrm{~mm}(-48+60 \mathrm{mesh})$, while utilization of DSS1 can be beneficial to relatively fine size such as minus 150 plus $0.075 \mathrm{~mm}(-100+200 \mathrm{mesh})$. Slimes can significantly deteriorate the dolomite flotation. When surfactants are used with FAS-40A as dolomite flotation collector, dolomite flotation recovery can be improved. The magnitude of such improvement is in the order of DSS1 > DP > TW.

3. Some researchers applied pure dolomite and apatite mineral samples to demonstrate the separation of dolomite from phosphate. The results showed that the best separation performance was achieved by floating dolomite at acidic $\mathrm{pH}<5$ or floating phosphate at alkaline $\mathrm{pH}>9$. Unlike the test results using pure dolomite and apatite samples, the dolomite in natural phosphate ores is more floatable than phosphate in the $\mathrm{pH}$ range from 3 to 11 , but the best separation result can be obtained at $\mathrm{pH}$ 5. At higher $\mathrm{pH}$, more phosphate will report to float which will lead to high $\mathrm{P}_{2} \mathrm{O}_{5}$ loss. At lower acidic condition such as $\mathrm{pH}<4$, more dolomite will be depressed.

4. Surfactants can be used to improve dolomite flotation. Among three surfactants selected in this study, DP used with FAS-40A can increase dolomite flotation float and to some extent improve the removal of dolomite mineral at relatively low collector dosages of less than $1.5 \mathrm{~kg} / \mathrm{t}$. Further increasing collector dosage to more than $1.5 \mathrm{~kg} / \mathrm{t}$ can not further improve the separation performance.

5. Addition of surfactant DSS1 into dolomite collector FAS-40A can significantly improve dolomite flotation by increasing dolomite flotation float, achieving better 
separation selectivity and easier control of the flotation process. Better separation selectivity can be observed by increasing the removal rate of dolomite into float while reducing $\mathrm{P}_{2} \mathrm{O}_{5}$ loss into tailings. Application of surfactant DSS1 with fatty acid collector FAS-40A can also reduce the acid insoluble content in the float product by preventing silicate minerals from floating.

6. Utilization of surfactant DSS1 can improve the properties of the froth product such as smaller bubble size and more homogeneous bubble size distribution. Bubbles are better mineralized which will facilitate the dewatering process of the froth product for recovering of process water.

7. Due to the low proportion of dolomite mineral particles in the dolomitic phosphate pebble tested, it is difficult to generate a stable froth layer at the top of the original packed column during flotation. Therefore, a sparger is added to produce fine size bubbles for increasing the probability of dolomite particles attaching to bubbles as well as stabilizing the froth layer.

8. Modified packed flotation column can be utilized for dolomite flotation from dolomitic phosphate ores. The underflow of dolomite flotation containing 26.9\% $\mathrm{P}_{2} \mathrm{O}_{5}$ and $0.95 \% \mathrm{MgO}$ can be obtained at the $\mathrm{P}_{2} \mathrm{O}_{5}$ recovery of $88.8 \%$. The separation result of modified packed flotation column is not as good as that of stirred-tank flotation cell in terms of $\mathrm{MgO}$ grade and $\mathrm{P}_{2} \mathrm{O}_{5}$ recovery in the underflow in this study. It can also be noted that flotation column requires at least $50 \%$ more collector in order to be as effective as the stirred-tank cell flotation. Further study is needed to 
determine the optimum operation conditions for dolomite column flotation.

9. In the reduced model developed from experiment design statistics analysis by JMP, there is no froth height term. One reason is the low proportion of dolomite mineral in the phosphate sample for flotation. Second reason is the small size of the bubbles. The fine size bubbles generated by sparger stabilized the froth layer despite the low content of dolomite particles in the froth.

10. The $\mathrm{MgO}$ grade in the DPP feed sample used for packed column flotation test is lower than expected, only 1.3 to $1.5 \%$. The changes in the separation results are not very sensitive to the changes of the operation parameters of the modified packed flotation column.

11. The modified packed column flotation test results demonstrate that surfactant DSS1 can enhance the effectiveness of fatty acid soap as dolomite collector, and can significantly improve the separation selectivity of dolomite flotation by removing more dolomite into float and lowering dolomite quantity in the concentrate. When $10 \%$ of DSS1 was used with FAS-40A as collector, about $10 \%$ more dolomite can be removed and $\mathrm{MgO}$ content in the rougher concentrate can be reduced to $0.8 \%$. The overall $\mathrm{P}_{2} \mathrm{O}_{5}$ recovery can be as high as $88 \%$. 


\section{RECOMMENDATIONS}

The experiment data indicated that dolomite flotation could be significantly improved through usage of surfactants. This study mostly focused on practical aspect to find appropriate surfactants for dolomite flotation. The test results have been well illustrated by Hallimond cell flotation, stirrer-tank cell flotation and packed column flotation. The studies revealed that the flotation performance of separating dolomite from phosphate was, to some extent, relevant to the frothability and froth stability of the collector, but there is no doubt that this is not the only explanation. In order to further understand the mechanism of the synergistic function of the surfactants in dolomite flotation, the following recommendations are proposed for future studies:

1. Froth flotation is a three-phase process in which the separation is performed in the interface between air and liquid. Therefore, bubbles play a very important role in flotation. The properties of the bubble have direct effect on flotation performance, such as its structure, size, quantity as well as stability. In this study, the effect of surfactant on frothability and froth stability of the fatty acid collector was investigated. The bubble size and its distribution in the presence of different surfactant at various dosages should be measured to find their effect on flotation performance. 
2. The dynamic surface tension, dynamic contact angle, adsorption and solution chemistry should be studied for in-depth understanding of the theoretical aspects of the improvement in separation selectivity of dolomite flotation using the mixture of FAS-40A and selected surfactants.

3. In this study, one fatty acid soap collector and three surfactants were selected. It is recommended that more reagents should be tested in the future, including different fatty acid type collectors and other surfactants.

4. Hallimond cell flotation, stirrer-tank cell batch flotation and modified packed column flotation have been carried out in this study. It is recommended that an open column with frother addition to generate small size bubbles be used for the flotation tests on dolomitic phosphate ores. Pilot plant test is also recommended to further demonstrate the effectiveness of selected surfactant on dolomite flotation using fatty acid type collectors. 


\section{REFERENCES}

Abdel-Khalek, M. A., "Separation of Dolomite from Phosphate Minerals by Flotation with a New Amphoteric Surfactant as Collector", Transactions of the Institution of Mining and Metallurgy, Section C: Mineral Processing and Extractive Metallurgy, v. 110, pp. C89-C93.

Abromov, A. A., Abromov, Al. Al., Onal, G., Atak, S., and Celik, M. S., 1993, "Mechanism of Reverse Flotation of Calcareous Phosphate Ores", in Beneficiation of Phosphates: Theory and Practice, El-Shall, H., Moudgil, B., Wiegel, R., eds., SME, Littleton, CO, pp.281-288.

Abu-Elshah, S. I., 1991, "A New Technique for the Beneficiation of Low Grade Carbonate Rich Phosphate Rocks by Digestion with Dilute Acetic Acid Solutions: Pilot Plant Testing Results", Minerals Engineering, Vol. 4 (5/6), pp. 573-586.

Al-Fariss, T. F., 1993, "Beneficiation of a Carbonate Rich Saudi Phosphate Rocks", Engineering Foundation Conference. Beneficiation of Phosphates: Theory and Practice", El-Shall, H., Moudgil, B., Wiegel, R., eds., SME, Littleton, CO., pp.251-259.

Henchiri, A., 1993, "A Contribution to Carbonates-Phosphate Separation by flotation Technique", Beneficiation of Phosphates: Theory and Practice", El-Shall, H., Moudgil, B., Wiegel, R., eds., SME, Littleton, CO., pp.225-230.

Anazia, I., and Hanna, J., 1988, "Innovative Process for Beneficiation of Dolomite 
Phosphate Ores”, Int. J. Mineral Processing, Vol. 23, No. 3-4, pp.311-314.

Ananthapadmanabhan, K. P., and Somasundaran, P., 1985, "Surface Precipitation of Inorganic and Surfactants and its Role in Adsorption and Flotation", Colloids Surfaces, Vol. 13, pp. 151-167.

Atalay, V., 1985, "Beneficiation of Low Grade Tasit Phosphate Ore from Turkey", In Proceedings, World Congress on Non-Metallic Minerals, Belgrade, Yugoslavia, April, pp. 389-396.

Baumann, A. N., and Snow, R. E., 1980, "Processing Techniques for Separating MgO Impurities from Phosphate Products", In Proceedings, 2nd Intl Congr. Phosphorus Compounds, April, pp. 269-280.

Boutin, P., and Wheeler, D. A., 1967, “Column Flotation”, Min. World, Vol. 20, No. 3, pp. 47-50.

Belyakov, V. A., 1981, "Effect of Conditions for the Acid Leaching of Carbonates from Kingisepp Phosphrites on the Particle Size Distribution and Flotation Properties of Solid Phases", Tekhnol, Mineral'n Udobrenii, L (Russ), pp. 3-9.

Booth, R. B., and Freyberger, W. L., 1962, "Froths and Frothing Agents", Froth Flotation $50^{\text {th }}$ Anniversary Volumn, ed. by Fuerstenau, Published by the Ameriacn Institute of Mining, Metallurgical, Petroleum Engineers, Inc., pp. 258-276. 
Clerici, C., 1984, "Flotation of a Phosphate Rock with Carbonate-Quartz Gangue", Reagents in the Mineral Industry, Jones, M.J. and Oblatt, R., eds., IMM, London, pp. 221-225.

Davis, B. E., Liewellyn, T. O., and Smith, C. W., 1984, "Continuous Beneficiation of Dolomitic Phosphate Rocks", RI 8903, USBM.

Dey, S., and Bhattacharya, S., 1998, "Comparative Performance Analysis of Frothers-A Review of Available Methodologies”, Min. Proc. Ext. Metall. Rev., Vol. 18, pp.201-213.

Elgrilani, D. A., and Abouzeid, A. Z. M., 1993, "Flotation of Carbonates from Phosphate Ores in Acidic Media”, Int. J. Mineral Processing, Vol. 38, pp.235-256.

El-Midany, A., El-Shall, H., Stana, R., Svoronos, S., and Moudgil, B., 2005, "Selective Separation of Carbonate Minerals by Reactive Flotation", Innovations in Natural Resource Processing, edited by Young, A., at al., pp.113-123.

El-Shall, H., Zhang, P. and Snow, R., 1996, "Comparative Analysis of Dolomite/Francolite Flotation Techniques", Minerals and Metallurgical Processing, pp. 135-140.

El-Shall, H., Cheng, Y. H., Abdel-Khalek, N. A. and Gupta, S., 1999, “A Parametric Study of Column Flotation of Florida Phosphates", Beneficiation of Phosphates: "Advance in Research and Practice", Zhang, P., El-Shall, H., Wiegel, R., eds., SME, Littleton, CO., pp. 75-86

Espinosa-Gomez, R., Finch, J. A., Yianatos, J. B. and Dobby, G. S., 1988, "Flotation Column Carrying Capacity: Particle Size and Density Effects”, Mineral Engineering, Vol. 
1, No. 1, pp. 77-79.

Finch, J. A. and Dobby, G. S., 1990, “Column Flotation”, $1^{\text {st }}$ ed., Pergmon Press, New York, NY, pp. 25-26, 75-102

Finch, J. A., and Smith, G. W., 1981, "Contact Angle and Wetting”, Anionic Surfactants, Physical Chemistry of Surfactant Action, Surfactant Science Series, Vol. 11, pp317-384.

Fu, E., and Somasundaran, P., 1986, "Alizarin Red S as a Flotation Modifying Agent in Calcite-Apatite Systems", Int. J. of Mineral Processing, 18, pp. 287-296.

Fuerstenau, D. W., Metzger, P. H., and Steele, G. G., 1957, "How to Use the Modified Hallimond Tube”, Engineering and Mining Journal, Vol. 158, pp. 93-95.

Fuerstenau, M. C., et al., 1968, "The Influence of Sodium Silicate in Non-Metallic Flotation Systems", Trans AIME, Vol. 241, pp. 319-323.

Gao Z. Z., and Gu Z. X., 1999, "Plant Practice of Phosphate Beneficiation in China", Beneficiation of Phosphates: "Advance in Research and Practice", Zhang, P., El-Shall, H., Wiegel, R., eds., SME, Littleton, CO., pp. 289-301.

Good, P. C., 1976, "Beneficiation of Unweathered Indian Calcareous Phosphate Rock by Calcination and Hydration", U. S. Government Printing Office, 1976-603-755/129, pp. $1-17$.

Gruber, G. A., Raulerson J. D., and Farias, R. P., 1987, "Adapting Technoloey to Beneficiate a Low-Grade Phosphorite Ore", Minerals and Metallurgical Processing, 
Feb., pp. 14-18.

Gruber, G. A., Zheng, S. B., and Hwang C. L., 2001, "A Pilot-Scale Demonstration of the IMC/CLDRI/FIPR Flotation Process for Florida High-MgO Pebble", Final report submitted to Florida Institute of Phosphate Research, publication No. 02-133-178.

Gu, Z. X., 2002, "Fine Particle Flotation for Florida Dolomitic Phosphate Pebbles", Master Thesis, West Virginia University.

Gu, Z. X., Gao, Z. Z., and Hwang C. L., 1999, "Development of New Technology for Beneficiation of Florida Dolomitic Phosphate Resources", Final report submitted to Florida Institute of Phosphate Research, publication No. 02-129-167.

Gu, Z. X., Gao Z. Z., and Zheng S. B., 1999, "Beneficiation of Florida Dolomitic Phosphate Pebble with a Fine Particle Flotation Process", Beneficiation of Phosphates: "Advance in Research and Practice", Zhang, P., El-Shall, H., Wiegel, R., eds., SME, Littleton, CO., pp.155-162.

Hanna, J., and Anazia, I., 1990, "Selective Flotation of Dolomitic Limestone Impurities from Florida Phosphates", FIPR Publication No. 02-066-089.

Hanna, H. S., and Somsundaran, P., 1976, "Flotation”, A. M. Gaudin Memorial Volume, M. C. Fuerstenau ed., Vol. 1, AIME, N.Y., 197-272.

Houot, R., 1982 "Beneficiation of Phosphatic Ores through Flotation: Review of Industrial Applications and Potential Developments," Intl J. of Mineral Process., Vol.9, p.353-384. 
Houot, R., Joussement, R., Tracez, J., and Brouard, R., 1985, "Selective Flotation of Phosphate Ores Having A Siliceous and/or Carbonated Gangue”, Int. J. Miner. Process., Vol. 14, pp. 245-264.

Houot, R., and Polgaire, J. L., 1980, "Inverse Flotation Beneficiation of Phosphate Ores", In Proceedings, 2nd International Congress on Phosphorus Compounds, Boston, April, pp. 231-246.

Hsieh, S. S., and Lehr, J. R., 1985, "Beneficiation of Dolomitic Idaho Phosphate Rock by the TVA Diphosphonic Depressant Process", Mineral and Metallurgical processing, Feb., pp. 10-13.

Huang, W. G., and Zhang, G. L., 1993 "Beneficiating Baokang Phosphate ore with Heavy Medium Separation Process," Chemical Mines Technology, No.2, p.24

Hutwelker, J.F., 1994, “High Throughput Flotation Column Process,” U.S. Patent No. $5,307,937$.

Johnston, D. J., and Leja, J., 1978, "Flotation Behavior of Calcium Phosphates and Carbonates in Orthophosphate Solution", Trans. Inst. Min. Metall. (Sect. C: Miner. Process. Extr. Metall.), pp. C-237.

Laird, D. H., and Ng, D., 1992, "Magnesium Separation from Dolomitic Phosphate by Acid Leaching", Final Report, FIPR Project \#91-01-093.

Lawendy, T. A. B., and McClellan, G. H., 1993, "Flotation of Dolomitic and Calcareous 
Phosphate Ores", 1993, Beneficiation of Phosphates: Theory and Practice, El-Shall, H., Moudgil, B., Wiegel, R., eds., SME, Littleton, CO., pp.231-244.

Lawver, L. E., and Snow, R. E., 1980, "Method of Beneficiating Phosphate Ores", U. S. Patent 4,189,103, Feb. 19.

Lehr, J. R., and Hsieh, S. S., 1981, "Beneficiation of High Carbonate Phosphate Ores", U. S._Patent 4,287,053.

Li, B., Tao, D., Ou, Z., and Liu, J., 2003, "Cyclo-microbubble Column Flotation of Fine Coal”, Separation Science and Technology, Vol. 38, No. 5, pp. 1125-1140.

Llewellyn, T. D., "Beneficiation of High-Magnesium Phosphate from Southern Florida, 1982, RI 8609, USBM.

Lu S. C., and Sun K. J., 1999, "Development of Phosphate Flotation Reagents in China”, Engineering Foundation Conference. Beneficiation of Phosphates: "Advance in Research and Practice", Zhang, P., El-Shall, H., Wiegel, R., eds., SME, Littleton, CO., pp.21-26.

Mahlanggu, T., Nyamhunga, M., Simbi, D. J. and Fernandes, T. R. C., 1999, "Column Flotation of Dorowa Rock Phosphate Slimes", Beneficiation of Phosphates: “Advance in Research and Practice", Zhang, P., El-Shall, H., Wiegel, R., eds., SME, Littleton, CO., pp.95-101.

Mitzmager, A., Mizrahi, J., and Fischer, E., 1966, "Flotation of Calcite from Phosphate Slimes, Effect of Soluble Alkali Phosphate Salts", Trans. Inst. Min. Metall. (Sect. C: 
Miner. Process. Extr. Metall.), pp. C233-239.

Moudgil, B. M., and Chanchani, R., 1985, "Flotation of Apatite and Dolomite Using Sodium Oleate as the Collector", Minerals and Metallurgical Processing, Vol. 2, No. 1, pp.13-19.

Moudgil, B. M., and Ince, D., 1991, "Effect of Sodium Chloride on Flotation of Dolomite from Phosphate”, Minerals and Metallurgical Processing, Vol. 8, No. 3, pp.139-143.

Moudgil, B. M., and Somasundaran, P., 1986, "Advances in Phosphate Beneficiation," Advances in Mineral Processing, Arbiter Symposium, SME, pp.426.

Moudgil, B. M., et al., 1986, "Separation of Dolomite From the South Florida Phosphate Rock", FIPR Publication No. 02-023-051.

Prasad, M., Majunder, A. K., and Rao, T. C., 2000, "Reverse Flotation of Sedimentary Calcareous/Dolomitic Rock Phosphate Ore-An Overview”, Minerals and Metallurgical Processing, Vol. 17, No. 1, pp.49-55.

Peng, F. F., and Gu, Z. X., 2005, "Processing Florida Dolomitic Phosphate Pebble in a Double Reverse Fine Flotation Process", Minerals and Metallurgical Processing, Vol. 22, No. 1, pp.23-30.

Peng, F. F., and Xia, Y. K., 2002, "Evaluation of Solvents for the Frothers of Copper-Molybdenite Sulfide Mineral Flotation”, Preprint 02-196, 2002 SME Annual Meeting, Phoenix, AZ, Feb. 25-27 
Peng, F. F., and Xia, Y. K., 2002, "Stability of Foam and Frother Evaluation Methodology", Preprint 02-184, 2002 SME Annual Meeting, Phoenix, AZ, Feb. 25-27

Peng L., 1989, Review on Beneficiation Processes for Phosphate Rocks from Hujie Area," Chemical Mines Technology, No.6, p.16.

Peng L., 1992, "Studies on Double Reverse Flotation of Calcareous- Siliceous Phosphate Rocks,"Chemical Mines Technology, No.2, p.30

Rao, D. V., 1985, "Flotation of Calcareous Mussorie Phosphate Ore", Int. J. Mineral Processing, Vol. 14, pp. 57-66.

Rao, D. V., 1979, "Flotation of Low Grade Phosphate Ore", Int. Symp. on Resources Eng. and Tech., Jan. 8-11, pp. 1-7.

Rao, K. H., Antti, B. M., and Forssberg, E., 1989, "Flotation of Phosphatic Material Containing Carbonatic Gangue Using Sodium Oleate as Collector and Sodium Silicate as Modifier", Intl. J of Mineral Process., Vol. 26, pp. 123-140.

Rao, H. K., et al., 1988, "Mechanism of Oleate Interaction on Salt-type Minerals, I. Adsorption and Electrokinetic Studies of Calcite in the Presence of Sodium Oleate and Sodium Metasilicate", Colloids Surfaces, Vol. 34, pp. 227-239.

Rule, A. R., 1985, "Beneficiation of Complex Phosphate Ores Containing Carbonate and Silica Gangue", In Proceedings, XVth IMPC, Vol. 3, pp. 380-389. 
Rule, A. R., 1970, "Removal of Magnesium Impurities from Phosphate Rock Concentrates", USBM RI 7362.

Rule, A. R., 1982, "Application of Carbonate-Silica Flotation Techniques to Western Phosphate Materials", RI 8728, USBM.

Sampat-Kumar, V. Y., Mohan, N., and Biswas, A. K., 1971, "Fundamental Studies on the Role of Carbon Dioxide in a Calcite Flotation System", Trans. SME-AIME, Vol. 250, pp. 182-186.

Saint-Guilhem, R., 1975, "La Valorisation des Phosphates Mineraux Pauvres a Gangue Carnobatee", Reprients 11, Congres International de Valorisation des Minerais Seminaire sur, pp. 3-15.

Seth, V., Kumar, R., Arora, S.C.D., and Biwas, A.K., 1975, "Disodium Dodecyl Phosphate as a Collector in the Calcite-Apatite Mineral System”, Trans. Inst. Min. Metall, v. 84, pp. C56-C58.

Shao, X., Jiang, C., and Parekh, B. K., 1999, "Flotation Separation of Phosphate and Dolomite Using a New Amphoteric Collector", Beneficiation of Phosphates: “Advance in Research and Practice", Zhang, P., El-Shall, H., Wiegel, R., eds., SME, Littleton, CO., pp.187-192.

Sis, H., 2001, "Enhancing Flotation Recovery of Phosphate Ores Using Nonionic Surfactants", Ph.D. Thesis.

Smani, S., Cases, J. M., and Blazy, P., 1975, "Beneficiation of Sedimentary Moroccan 
Phosphate Ore", Part 1, 2, 3 and 4, Trans. SME-AIME, Vol. 258, pp 168-182.

Soto, H., and Iwasaki, I., 1986, "Selective Flotation of Phosphates from Dolomite Using Cationic Collectors", Intl J. of Mineral Process., No.16, p.3-27.

Somasundaran, P., Xiao, L., and Viswanathan, K.V., 1987, "Interactions between Dissolved Mineral Species and Surfactants in the Francolite/Dolomite Flotation”, Proceedings of International Symposium organized by Central-South University of Technology and Technical University of Clausthal, Changsha, China, Sept. 21-24.

Tang Y. F., 1989, "Effects of Phosphate on Flotation of Francolite and Dolomite," Chemical Mines Technology, No.5, p.20.

Tang D. S., 1984, "Studies on Separation of Dolomite from Phosphate," Chemical Mines Technology, No.1, p.31.

Wei Q. S., 1992, "Continuous Test for Baokang Phosphate Ore with Reverse-Direct Flotation Flowsheet,"Chemical Mines Technology, No.2, p.61

Wiegel, R. L., 1999, "Phosphate Rock Beneficiation Practice in Florida”, Beneficiation of Phosphates: "Advance in Research and Practice", Zhang, P., El-Shall, H., Wiegel, R., eds., SME, Littleton, CO., pp.271-275.

Wu, L., and Forsling, W., 1993, "Surface Complexation of Calcium Minerals in Aqueous Solution - 2. The Complexation of Alizarin Red S at Fluorapatite-Water Interface", 1993, "Beneficiation of Phosphate: Theory and Practice." El-Shall, H., Moudgil, B., Wiegel, R., eds., SME, Littleton, CO., pp. 45-56. 
Wu L. T., 1985, "Studies on Removal of Magnesium Impurities from Carbonated Phosphate Rocks with Reverse Flotation Process," In Proceedings of the First Symposium of Phosphate Beneficiation in China.

Wu, L. T., and Yang, Z.W., 1983, Proceedings of IFA/CNCCC Technical Seminar on Phosphate Fertilizer, pp. 17-36.

Xiao, L., Kunjappu, J. T., and Somasundaran, P., 1989, "Surface and Bulk Precipitation of Oleate in Fracolite/Dolomite Systems", private communication.

Xiao, L., and Somasundaran, P., 1989, "Interactions Between Oleate Collector and Alizarin Modifier in Dolomite/Francolite Flotation System," Minerals and Metallurgical Processing, May, pp. 100-103.

Yang, D. C., 1991, “Technical Advantages of Packed Flotation Columns”, Column'91, Proceedings, Intl Conference on Column Flotation, Agar, G. A., Huls, B. J., and Hyma, D. B., Eds. Sudbury, Ontario, Canada, June 2-6, pp. 631-646.

Yang Z. W., 1986, "Prospects for Development of Flotation Reagents for Phosphate Beneficiation," Chemical Mines Technology, No.1, p.9.

Zeng M. Y., 1998, "Recovery of Coal Fines Using Packed Column Flotation with Reagent Enhancement", M. S. thesis, West Virginia University

Zhang, P., 1993, "Phosphate Beneficiation-Trends of 90's," "Beneficiation of Phosphate: Theory and Practice." El-Shall, H., Moudgil, B., Wiegel, R., eds., SME, Littleton, CO., 
pp.399-425.

Zheng, X., Merrill P. A., and Ross W. S., 2002, "A Two Stage Flotation Process for Reducing $\mathrm{MgO}$ in a Fine Phosphate Process Stream", Beneficiation of Phosphates: "Fundamental and Technology", Zhang, P., El-Shall, H., Somasundaran, P., Stana, R., eds., SME, Littleton, CO., pp.187-192.

Zhong K. L., et al., 1986, "Studies on Reverse Flotation of Francolite," Chemical Mines Technology, No.2, p.26 


\section{APPENDIX A}

Size distribution and chemical analysis of dolomitic phosphate samples 
Table A-1 Size distribution and chemical analysis of dolomitic phosphate pebble sample $\mathrm{H}$

\begin{tabular}{|c|c|c|c|c|c|c|c|c|c|c|c|c|c|}
\hline \multirow{2}{*}{$\begin{array}{c}\text { Size } \\
\text { US sieve no. }(\mathrm{mm})\end{array}$} & \multirow{2}{*}{ Wt. \% } & \multicolumn{6}{|c|}{ Grade, $\%$} & \multicolumn{6}{|c|}{ Recovery, \% } \\
\hline & & $\mathrm{P}_{2} \mathrm{O}_{5}$ & $\mathrm{MgO}$ & Insol & $\mathrm{Fe}_{2} \mathrm{O}_{3}$ & $\mathrm{Al}_{2} \mathrm{O}_{3}$ & $\mathrm{CaO}$ & $\mathrm{P}_{2} \mathrm{O}_{5}$ & $\mathrm{MgO}$ & Insol & $\mathrm{Fe}_{2} \mathrm{O}_{3}$ & $\mathrm{Al}_{2} \mathrm{O}_{3}$ & $\mathrm{CaO}$ \\
\hline+0.25 in $(6.3 \mathrm{~mm})$ & 44.84 & 23.4 & 3.68 & 10.53 & 0.87 & 0.76 & 39.20 & 43.43 & 49.33 & 40.86 & 45.59 & 38.35 & 44.38 \\
\hline +No. $8(2.38 \mathrm{~mm})$ & 8.86 & 26.6 & 2.47 & 9.93 & 0.81 & 1.00 & & & 6.53 & 7.62 & 8.36 & 10.04 & 9.15 \\
\hline+ No. $18(1.0 \mathrm{~mm})$ & 7.84 & 27.5 & 1.34 & 15.47 & 0.73 & 0.95 & 39.33 & 8.93 & 3.14 & 10.50 & 6.70 & 8.41 & 7.79 \\
\hline -No. $150(0.1 \mathrm{~mm})$ & 3.06 & 18.2 & 5.12 & 15.34 & 1.74 & 1.81 & 33.50 & 2.31 & 4.68 & 4.06 & 6.25 & 6.26 & 2.59 \\
\hline Head & 100.00 & 24.16 & 3.35 & 11.56 & 0.85 & 0.88 & 39.61 & 100.00 & 100.00 & 100.00 & 100.00 & 100.00 & 100.00 \\
\hline
\end{tabular}


Table A-2 Chemical analysis of the as-received sample $\mathrm{H}$

\begin{tabular}{|c|c|c|c|c|c|c|}
\hline Component & $\mathrm{P}_{2} \mathrm{O}_{5}$ & $\mathrm{CaO}$ & $\mathrm{Fe}_{2} \mathrm{O}_{3}$ & $\mathrm{Al}_{2} \mathrm{O}_{3}$ & $\mathrm{MgO}$ & Insoluble \\
\hline$\%$ & 23.70 & 38.58 & 0.96 & 0.83 & 3.34 & 12.46 \\
\hline
\end{tabular}

Table A-3 Size distribution and chemical analysis after the sample was crushed to

minus $1.18 \mathrm{~mm}$ (14 mesh) of sample $\mathrm{H}$

\begin{tabular}{|c|c|c|c|c|c|c|c|}
\hline \multirow{2}{*}{$\begin{array}{c}\text { Size } \\
(\mathrm{mesh})\end{array}$} & \multirow{2}{*}{$\mathrm{Wt} \%$} & \multicolumn{7}{|c|}{ Assay, \% } \\
\cline { 3 - 8 } & & $\mathrm{P}_{2} \mathrm{O}_{5}$ & $\mathrm{CaO}$ & $\mathrm{Fe}_{2} \mathrm{O}_{3}$ & $\mathrm{Al}_{2} \mathrm{O}_{3}$ & $\mathrm{MgO}$ & Insoluble \\
\hline$-14+30$ & 35.82 & 24.80 & 39.42 & 0.75 & 0.69 & 2.63 & 8.01 \\
\hline$-30+60$ & 29.13 & 23.10 & 37.31 & 0.74 & 0.66 & 2.62 & 14.21 \\
\hline$-60+100$ & 11.49 & 21.30 & 34.10 & 0.73 & 0.65 & 2.20 & 19.71 \\
\hline$-100+200$ & 9.26 & 23.60 & 36.67 & 0.85 & 0.77 & 2.30 & 13.27 \\
\hline$-200+400$ & 5.07 & 24.60 & 37.46 & 0.93 & 0.81 & 2.82 & 7.15 \\
\hline-400 & 9.22 & 18.00 & 34.64 & 0.94 & 0.91 & 5.91 & 4.06 \\
\hline Total & 100.00 & 23.15 & 37.40 & 0.78 & 0.71 & 2.86 & 11.24 \\
\hline
\end{tabular}

Table A-4 Size distribution and chemical analysis of flotation feed of sample H (after the sample was ground in rod mill)

\begin{tabular}{|c|c|c|c|c|c|c|c|}
\hline \multirow{2}{*}{$\begin{array}{c}\text { Size } \\
(\mathrm{mm})\end{array}$} & \multirow{2}{*}{$\mathrm{Wt} \%$} & \multicolumn{6}{|c|}{ Assay, $\%$} \\
\cline { 3 - 8 } & & $\mathrm{P}_{2} \mathrm{O}_{5}$ & $\mathrm{CaO}$ & $\mathrm{Fe}_{2} \mathrm{O}_{3}$ & $\mathrm{Al}_{2} \mathrm{O}_{3}$ & $\mathrm{MgO}$ & Insoluble \\
\hline$-60+100$ & 4.62 & 24.1 & 37.5 & 0.71 & 0.57 & 1.22 & 17.84 \\
\hline $100+200$ & 35.83 & 23.9 & 36.76 & 0.75 & 0.65 & 1.78 & 14.66 \\
\hline$-200+400$ & 19.77 & 24.4 & 36.86 & 0.79 & 0.68 & 2.25 & 11.68 \\
\hline-400 & 39.78 & 20.5 & 35.28 & 0.87 & 0.81 & 4.5 & 6.08 \\
\hline & 100.00 & 22.66 & 36.23 & 0.80 & 0.72 & 2.93 & 10.80 \\
\hline
\end{tabular}


Table A-5 Size distribution and chemical analysis of dolomitic phosphate pebble sample L

\begin{tabular}{|c|c|c|c|c|c|c|c|c|c|c|c|c|c|}
\hline \multirow{2}{*}{$\begin{array}{c}\text { Size } \\
\text { US sieve no. }(\mathrm{mm})\end{array}$} & \multirow{2}{*}{ Wt. \% } & \multicolumn{6}{|c|}{ Grade, $\%$} & \multicolumn{6}{|c|}{ Recovery, \% } \\
\hline & & $\mathrm{P}_{2} \mathrm{O}_{5}$ & $\mathrm{MgO}$ & Insol & $\mathrm{Fe}_{2} \mathrm{O}_{3}$ & $\mathrm{Al}_{2} \mathrm{O}_{3}$ & $\mathrm{CaO}$ & $\mathrm{P}_{2} \mathrm{O}_{5}$ & $\mathrm{MgO}$ & Insol & $\mathrm{Fe}_{2} \mathrm{O}_{3}$ & $\mathrm{Al}_{2} \mathrm{O}_{3}$ & $\mathrm{CaO}$ \\
\hline+0.25 in $(6.3 \mathrm{~mm})$ & 5.45 & 15.26 & 7.57 & 15.52 & 1.33 & 0.87 & 33.47 & 3.16 & 24.66 & 6.01 & 7.79 & 4.73 & 4.74 \\
\hline +No. $5(4.0 \mathrm{~mm})$ & 8.35 & 22.74 & 4.37 & 11.14 & 0.86 & 0.95 & 39.05 & 7.22 & 21.83 & 6.62 & 7.72 & 7.93 & 8.48 \\
\hline+ No. $10(2.0 \mathrm{~mm})$ & 36.91 & 28.11 & 1.29 & 10.69 & 0.84 & 0.99 & 41.57 & 39.43 & 28.48 & 28.07 & 33.33 & 36.51 & 39.90 \\
\hline +No. $16(1.18 \mathrm{~mm})$ & 28.88 & 27.13 & 0.87 & 15.73 & 0.97 & 0.92 & 39.53 & 29.77 & 15.03 & 32.31 & 30.11 & 26.54 & 29.68 \\
\hline +No. $30(0.60 \mathrm{~mm})$ & 10.80 & 24.85 & 0.8 & 22.65 & 0.89 & 0.95 & 26.02 & 10.20 & 5.17 & 17.40 & 10.33 & 10.25 & 7.31 \\
\hline +No. $50(0.3 \mathrm{~mm})$ & 3.71 & 28.1 & 0.61 & 15.02 & 1.05 & 1.1 & 39.96 & 3.96 & 1.35 & 3.97 & 4.19 & 4.08 & 3.86 \\
\hline +No. 100 (0.15 mm) & 2.72 & 29.4 & 0.41 & 12.86 & 0.95 & 1.04 & 40.92 & 3.04 & 0.67 & 2.49 & 2.78 & 2.83 & 2.90 \\
\hline -No. 100(0.15 mm $)$ & 3.17 & 26.6 & 1.48 & 13.87 & 1.1 & 2.25 & 38.08 & 3.21 & 2.81 & 3.13 & 3.75 & 7.13 & 3.14 \\
\hline Head & 100.00 & 26.31 & 1.67 & 14.06 & 0.93 & 1.00 & 38.46 & 100.00 & 100.00 & 100.00 & 100.00 & 100.00 & 100.00 \\
\hline
\end{tabular}


Table A-6 Chemical analysis of the as-received dolomitic phosphate sample L

\begin{tabular}{|c|c|c|c|c|c|c|}
\hline Component & $\mathrm{P}_{2} \mathrm{O}_{5}$ & $\mathrm{CaO}$ & $\mathrm{Fe}_{2} \mathrm{O}_{3}$ & $\mathrm{Al}_{2} \mathrm{O}_{3}$ & $\mathrm{MgO}$ & Insoluble \\
\hline$\%$ & 26.14 & 43.02 & 0.81 & 1.38 & 1.54 & 8.83 \\
\hline
\end{tabular}

Table A-7 Size distribution after the sample was crushed to minus $1.18 \mathrm{~mm}$ (14 mesh) of sample $\mathrm{L}$

\begin{tabular}{|c|c|c|}
\hline $\begin{array}{c}\text { Size } \\
(\mathrm{mesh})\end{array}$ & $\mathrm{Wt}(\mathrm{g})$ & $\mathrm{Wt} \%$ \\
\hline$-14+30$ & 124.4 & 42.85 \\
\hline$-30+50$ & 58.8 & 20.25 \\
\hline$-50+60$ & 36.9 & 12.71 \\
\hline$-60+100$ & 19.1 & 6.58 \\
\hline$-100+200$ & 23.8 & 8.20 \\
\hline-200 & 27.3 & 9.40 \\
\hline & 290.3 & 100.00 \\
\hline
\end{tabular}

Table A-8 Size distribution of flotation feed of sample L (after the sample was ground in rod mill)

\begin{tabular}{|c|c|c|}
\hline $\begin{array}{c}\text { Size } \\
(\mathrm{mm})\end{array}$ & Wt.(g) & Wt.\% \\
\hline$-60+100$ & 11.2 & 3.69 \\
\hline$-100+200$ & 121.7 & 40.13 \\
\hline$-200+400$ & 60.4 & 19.91 \\
\hline$-400+635$ & 32.7 & 10.78 \\
\hline-635 & 77.3 & 25.49 \\
\hline & 303.3 & 100.00 \\
\hline
\end{tabular}




\section{APPENDIX B}

Measurement Data of Frothability and Froth Stability 
Table B-1 Foam height as a function of airflow rate at various dosages of FAS-40A collector $(\mathrm{cm})$

\begin{tabular}{|c|c|c|c|c|c|c|}
\hline \multirow{2}{*}{$\begin{array}{c}\text { Airflow rate } \\
(1 / \mathrm{min})\end{array}$} & \multirow{2}{*}{ Water } & \multicolumn{5}{|c|}{ FAS-40A concentration, g/l } \\
\cline { 3 - 7 } & & 0.20 & 0.40 & 0.60 & 0.80 & 1.00 \\
\hline 0.05 & 0.20 & 0.80 & 1.10 & 1.20 & 1.50 & 1.80 \\
\hline 0.10 & 0.35 & 1.00 & 1.50 & 1.70 & 1.90 & 2.10 \\
\hline 0.20 & 0.75 & 1.50 & 2.00 & 2.20 & 2.40 & 2.70 \\
\hline 0.30 & 1.15 & 2.00 & 2.50 & 2.75 & 2.90 & 3.25 \\
\hline 0.40 & 1.60 & 2.40 & 3.00 & 3.25 & 3.40 & 3.75 \\
\hline 0.50 & 2.00 & 2.90 & 3.40 & 3.60 & 4.00 & 4.25 \\
\hline 0.60 & 2.25 & 3.25 & 3.75 & 4.00 & 4.40 & 4.75 \\
\hline
\end{tabular}

Table B-2 Foam height as a function of airflow rate at various ratios of DSS1 to

FAS-40A collector* (cm)

\begin{tabular}{|c|c|c|c|c|c|c|}
\hline \multirow{2}{*}{$\begin{array}{c}\text { Airflow rate } \\
(1 / \mathrm{min})\end{array}$} & \multicolumn{6}{|c|}{ Ratio of DSS1 to FAS-40A, \% } \\
\cline { 2 - 7 } & 0 & 1 & 2.5 & 5 & 7.5 & 10 \\
\hline 0.10 & 1.50 & 1.60 & 1.70 & 2.00 & 2.50 & 4.00 \\
\hline 0.20 & 2.00 & 2.25 & 2.30 & 2.50 & 3.00 & 6.00 \\
\hline 0.30 & 2.50 & 2.75 & 2.85 & 3.00 & 4.00 & 9.00 \\
\hline 0.40 & 3.00 & 3.25 & 3.40 & 4.00 & 5.00 & 12.00 \\
\hline 0.50 & 3.40 & 3.75 & 4.00 & 4.75 & 6.00 & 14.00 \\
\hline 0.60 & 3.75 & 4.00 & 4.25 & 5.00 & 6.50 & 16.00 \\
\hline
\end{tabular}

* FAS-40A concentration is fixed at $0.4 \mathrm{~g} / \mathrm{l}$. 
Table B-3 Foam height as a function of airflow rate at various ratios of DP to FAS-40A collector* $(\mathrm{cm})$

\begin{tabular}{|c|c|c|c|c|c|c|}
\hline \multirow{2}{*}{$\begin{array}{c}\text { Airflow rate } \\
(1 / \mathrm{min})\end{array}$} & \multicolumn{6}{|c|}{ Ratio of DP to FAS-40A, \% } \\
\cline { 2 - 7 } & 0 & 1 & 2.5 & 5 & 7.5 & 10 \\
\hline 0.10 & 1.50 & 1.50 & 1.50 & 1.50 & 1.60 & 1.70 \\
\hline 0.20 & 2.00 & 2.00 & 2.25 & 2.25 & 2.50 & 2.75 \\
\hline 0.30 & 2.50 & 2.75 & 3.00 & 3.25 & 3.50 & 3.75 \\
\hline 0.40 & 3.00 & 3.25 & 3.70 & 3.95 & 4.30 & 4.50 \\
\hline 0.50 & 3.40 & 3.80 & 4.40 & 4.75 & 5.00 & 5.50 \\
\hline 0.60 & 3.75 & 4.10 & 4.80 & 5.25 & 5.75 & 6.00 \\
\hline
\end{tabular}

* FAS-40A concentration is fixed at $0.4 \mathrm{~g} / \mathrm{l}$.

Table B-4 Foam height as a function of airflow rate at various ratios of TW to FAS-40A collector* $(\mathrm{cm})$

\begin{tabular}{|c|c|c|c|c|c|c|}
\hline \multirow{2}{*}{$\begin{array}{c}\text { Airflow rate } \\
(1 / \mathrm{min})\end{array}$} & \multicolumn{6}{|c|}{ Ratio of TW to FAS-40A, \% } \\
\cline { 2 - 7 } & 0 & 1 & 2.5 & 5 & 7.5 & 10 \\
\hline 0.10 & 1.50 & 1.50 & 1.50 & 1.60 & 1.80 & 2.20 \\
\hline 0.20 & 2.00 & 2.00 & 2.10 & 2.20 & 2.25 & 2.75 \\
\hline 0.30 & 2.50 & 2.50 & 2.60 & 2.70 & 2.90 & 3.50 \\
\hline 0.40 & 3.00 & 3.00 & 3.10 & 3.25 & 3.50 & 4.50 \\
\hline 0.50 & 3.40 & 3.50 & 3.60 & 3.70 & 4.00 & 5.00 \\
\hline 0.60 & 3.75 & 3.75 & 3.80 & 3.90 & 4.40 & 5.50 \\
\hline
\end{tabular}

* FAS-40A concentration is fixed at $0.4 \mathrm{~g} / \mathrm{l}$. 
Table B-5 Lifetime of foams produced by FAS-40A collector in the presence and absence of surfactants

\begin{tabular}{|c|c|c|c|c|}
\hline \multirow{2}{*}{$\begin{array}{c}\text { FAS-40A } \\
\text { g/l }\end{array}$} & \multicolumn{4}{|c|}{ Lifetime, s } \\
\cline { 2 - 5 } & No surfactant & With 10\% TW & With 10\% DP & With 10\% DSS1 \\
\hline 0.2 & 4.0 & 12.0 & 14.0 & 19.0 \\
\hline 0.4 & 8.0 & 14.0 & 17.0 & 24.0 \\
\hline 0.6 & 9.0 & 15.0 & 19.0 & 31.0 \\
\hline 0.8 & 12.0 & 16.0 & 20.0 & 35.0 \\
\hline 1.0 & 14.0 & 17.0 & 20.0 & 40.0 \\
\hline
\end{tabular}


APPENDIX C

Batch Stirrer-tank Cell Flotation Data 
Table C-1 pH effect on dolomite flotation

(FAS-40A: $2.5 \mathrm{~kg} / \mathrm{t}$ of feed)

\begin{tabular}{|c|c|c|c|c|c|c|c|c|c|}
\hline \multirow{2}{*}{$\mathrm{pH}$} & \multirow{2}{*}{ Product } & \multirow{2}{*}{ Wt.\% } & \multicolumn{3}{|c|}{ Grade, $\%$} & \multicolumn{3}{|c|}{ Recovery, \% } & \multirow{2}{*}{ SI } \\
\hline & & & $\mathrm{P}_{2} \mathrm{O}_{5}$ & $\mathrm{MgO}$ & AI & $\mathrm{P}_{2} \mathrm{O}_{5}$ & $\mathrm{MgO}$ & $\mathrm{AI}$ & \\
\hline \multirow{3}{*}{3.5} & Float & 6.14 & 13.30 & 8.17 & 5.50 & 3.43 & 17.44 & 2.89 & \multirow{3}{*}{30.34} \\
\hline & Sink & 93.86 & 24.50 & 2.53 & 12.08 & 96.57 & 82.56 & 97.11 & \\
\hline & Feed & 100.00 & 23.81 & 2.88 & 11.68 & 100.00 & 100.00 & 100.00 & \\
\hline \multirow{3}{*}{4.4} & Float & 12.87 & 10.10 & 9.98 & 4.55 & 5.55 & 43.68 & 5.12 & \multirow{3}{*}{50.41} \\
\hline & Sink & 87.13 & 25.40 & 1.90 & 12.46 & 94.45 & 56.32 & 94.88 & \\
\hline & Feed & 100.00 & 23.43 & 2.94 & 11.44 & 100.00 & 100.00 & 100.00 & \\
\hline \multirow{3}{*}{4.6} & Float & 16.30 & 9.90 & 9.76 & 4.62 & 6.93 & 55.57 & 6.84 & \multirow{3}{*}{57.07} \\
\hline & Sink & 83.70 & 25.90 & 1.52 & 12.25 & 93.07 & 44.43 & 93.16 & \\
\hline & Feed & 100.00 & 23.29 & 2.86 & 11.01 & 100.00 & 100.00 & 100.00 & \\
\hline \multirow{3}{*}{5} & Float & 19.93 & 11.20 & 9.69 & 4.73 & 9.96 & 59.67 & 8.33 & \multirow{3}{*}{55.97} \\
\hline & Sink & 80.07 & 25.20 & 1.63 & 12.95 & 90.04 & 40.33 & 91.67 & \\
\hline & Feed & 100.00 & 22.41 & 3.24 & 11.31 & 100.00 & 100.00 & 100.00 & \\
\hline \multirow{3}{*}{5.4} & Float & 20.12 & 14.60 & 9.08 & 3.06 & 12.52 & 52.73 & 5.72 & \multirow{3}{*}{50.12} \\
\hline & Sink & 79.88 & 25.70 & 2.05 & 12.71 & 87.48 & 47.27 & 94.28 & \\
\hline & Feed & 100.00 & 23.47 & 3.46 & 10.77 & 100.00 & 100.00 & 100.00 & \\
\hline \multirow{3}{*}{5.6} & Float & 32.08 & 19.10 & 6.49 & 4.80 & 26.52 & 65.43 & 13.94 & \multirow{3}{*}{44.56} \\
\hline & Sink & 67.92 & 25.00 & 1.62 & 14.00 & 73.48 & 34.57 & 86.06 & \\
\hline & Feed & 100.00 & 23.11 & 3.18 & 11.05 & 100.00 & 100.00 & 100.00 & \\
\hline \multirow{3}{*}{6} & Float & 33.22 & 19.90 & 5.91 & 4.77 & 28.61 & 62.82 & 14.34 & \multirow{3}{*}{40.93} \\
\hline & Sink & 66.78 & 24.70 & 1.74 & 14.18 & 71.39 & 37.18 & 85.66 & \\
\hline & Feed & 100.00 & 23.11 & 3.13 & 11.05 & 100.00 & 100.00 & 100.00 & \\
\hline \multirow{3}{*}{7.4} & Float & 38.67 & 20.10 & 5.44 & 4.77 & 33.11 & 69.72 & 16.73 & \multirow{3}{*}{41.73} \\
\hline & Sink & 61.33 & 25.60 & 1.49 & 14.97 & 66.89 & 30.28 & 83.27 & \\
\hline & Feed & 100.00 & 23.47 & 3.02 & 11.03 & 100.00 & 100.00 & 100.00 & \\
\hline \multirow{3}{*}{8.4} & Float & 42.25 & 20.60 & 4.95 & 6.26 & 37.06 & 70.30 & 24.26 & \multirow{3}{*}{38.57} \\
\hline & Sink & 57.75 & 25.60 & 1.53 & 14.30 & 62.94 & 29.70 & 75.74 & \\
\hline & Feed & 100.00 & 23.49 & 2.98 & 10.90 & 100.00 & 100.00 & 100.00 & \\
\hline \multirow{3}{*}{9.3} & Float & 58.54 & 21.20 & 3.90 & 8.10 & 53.90 & 81.86 & 43.36 & \multirow{3}{*}{30.28} \\
\hline & Sink & 41.46 & 25.60 & 1.22 & 14.94 & 46.10 & 18.14 & 56.64 & \\
\hline & Feed & 100.00 & 23.02 & 2.79 & 10.94 & 100.00 & 100.00 & 100.00 & \\
\hline \multirow{3}{*}{10.7} & Float & 71.49 & 21.80 & 4.46 & 9.57 & 67.60 & 91.57 & 62.27 & \\
\hline & Sink & 28.51 & 26.20 & 1.03 & 14.54 & 32.40 & 8.43 & 37.73 & 23.77 \\
\hline & Feed & 100.00 & 23.05 & 3.48 & 10.99 & 100.00 & 100.00 & 100.00 & \\
\hline
\end{tabular}


Table C-2 Effect of FAS-40A dosages on dolomite flotation in the absence of surfactants at $\mathrm{pH} 5.4$

\begin{tabular}{|c|c|c|c|c|c|c|c|c|c|}
\hline \multirow{2}{*}{$\begin{array}{c}\text { FAS-40A } \\
\mathrm{kg} / \mathrm{t}\end{array}$} & \multirow{2}{*}{ Product } & \multirow{2}{*}{$\mathrm{Wt} \%$} & \multicolumn{3}{|c|}{ Grade, $\%$} & \multicolumn{3}{|c|}{ Recovery, \% } & \multirow{2}{*}{ SI } \\
\hline & & & $\mathrm{P}_{2} \mathrm{O}_{5}$ & $\mathrm{MgO}$ & $\mathrm{AI}$ & $\mathrm{P}_{2} \mathrm{O}_{5}$ & $\mathrm{MgO}$ & $\mathrm{AI}$ & \\
\hline \multirow{3}{*}{0.5} & Float & 6.76 & 14.60 & 9.54 & 5.37 & 4.24 & 19.79 & 3.49 & \multirow{3}{*}{31.44} \\
\hline & Sink & 93.24 & 23.90 & 2.80 & 10.77 & 95.76 & 80.21 & 96.51 & \\
\hline & Feed & 100.00 & 23.27 & 3.26 & 10.41 & 100.00 & 100.00 & 100.00 & \\
\hline \multirow{3}{*}{1} & Float & 14.54 & 10.80 & 9.87 & 4.66 & 7.00 & 45.40 & 5.92 & \multirow{3}{*}{49.19} \\
\hline & Sink & 85.46 & 24.40 & 2.02 & 12.61 & 93.00 & 54.60 & 94.08 & \\
\hline & Feed & 100.00 & 22.42 & 3.16 & 11.45 & 100.00 & 100.00 & 100.00 & \\
\hline \multirow{3}{*}{1.5} & Float & 16.28 & 9.87 & 9.63 & 3.83 & 7.05 & 49.76 & 5.39 & \multirow{3}{*}{52.82} \\
\hline & Sink & 83.72 & 25.30 & 1.89 & 13.08 & 92.95 & 50.24 & 94.61 & \\
\hline & Feed & 100.00 & 22.79 & 3.15 & 11.57 & 100.00 & 100.00 & 100.00 & \\
\hline \multirow{3}{*}{2} & Float & 20.42 & 11.70 & 9.46 & 4.89 & 10.53 & 58.95 & 8.91 & \multirow{3}{*}{55.39} \\
\hline & Sink & 79.58 & 25.50 & 1.69 & 12.82 & 89.47 & 41.05 & 91.09 & \\
\hline & Feed & 100.00 & 22.68 & 3.28 & 11.20 & 100.00 & 100.00 & 100.00 & \\
\hline \multirow{3}{*}{2.5} & Float & 19.93 & 11.20 & 9.69 & 4.73 & 9.96 & 59.67 & 8.33 & \multirow{3}{*}{55.97} \\
\hline & Sink & 80.07 & 25.20 & 1.63 & 12.95 & 90.04 & 40.33 & 91.67 & \\
\hline & Feed & 100.00 & 22.41 & 3.24 & 11.31 & 100.00 & 100.00 & 100.00 & \\
\hline \multirow{3}{*}{3} & Float & 20.48 & 11.30 & 9.89 & 4.46 & 10.32 & 59.83 & 8.59 & \multirow{3}{*}{55.86} \\
\hline & Sink & 79.52 & 25.30 & 1.71 & 12.22 & 89.68 & 40.17 & 91.41 & \\
\hline & Feed & 100.00 & 22.43 & 3.39 & 10.63 & 100.00 & 100.00 & 100.00 & \\
\hline
\end{tabular}


Table C-3 Effect of the ratio of DSS1 to FAS-40A on dolomite flotation

(pH: 5.4 , FAS-40A: $1.5 \mathrm{~kg} / \mathrm{t}$ )

\begin{tabular}{|c|c|c|c|c|c|c|c|c|c|}
\hline \multirow{2}{*}{ DSS1 } & \multirow{2}{*}{ Product } & \multirow{2}{*}{$\mathrm{Wt} \%$} & \multicolumn{3}{|c|}{ Grade, \% } & \multicolumn{3}{|c|}{ Recovery, \% } & \multirow{2}{*}{ SI } \\
\hline & & & $\mathrm{P}_{2} \mathrm{O}_{5}$ & $\mathrm{MgO}$ & AI & $\mathrm{P}_{2} \mathrm{O}_{5}$ & $\mathrm{MgO}$ & AI & \\
\hline \multirow{3}{*}{$2.5 \%$} & Float & 13.08 & 9.17 & 10.46 & 3.32 & 4.97 & 41.94 & 4.19 & \multirow{3}{*}{50.76} \\
\hline & Sink & 86.92 & 26.4 & 2.18 & 11.44 & 95.03 & 58.06 & 95.81 & \\
\hline & Feed & 100.00 & 24.15 & 3.26 & 10.38 & 100.00 & 100.00 & 100.00 & \\
\hline \multirow{3}{*}{$5 \%$} & Float & 12.19 & 7.84 & 10.86 & 2.96 & 4.13 & 42.50 & 3.45 & \multirow{3}{*}{50.85} \\
\hline & Sink & 87.81 & 25.3 & 2.04 & 11.5 & 95.87 & 57.50 & 96.55 & \\
\hline & Feed & 100.00 & 23.17 & 3.12 & 10.46 & 100.00 & 100.00 & 100.00 & \\
\hline \multirow{3}{*}{$10 \%$} & Float & 17.66 & 8.03 & 10.96 & 2.77 & 6.02 & 60.91 & 4.64 & \multirow{3}{*}{62.09} \\
\hline & Sink & 82.34 & 26.9 & 1.51 & 12.22 & 93.98 & 39.09 & 95.36 & \\
\hline & Feed & 100.00 & 23.57 & 3.18 & 10.55 & 100.00 & 100.00 & 100.00 & \\
\hline \multirow{3}{*}{$15 \%$} & Float & 19.64 & 9.26 & 10.65 & 3.3 & 7.76 & 64.87 & 5.96 & \multirow{3}{*}{62.74} \\
\hline & Sink & 80.36 & 26.9 & 1.41 & 12.73 & 92.24 & 35.13 & 94.04 & \\
\hline & Feed & 100.00 & 23.44 & 3.23 & 10.88 & 100.00 & 100.00 & 100.00 & \\
\hline
\end{tabular}


Table C-4 Effect of the ratio of DP to FAS-40A on dolomite flotation

(pH: 5.4, FAS-40A: $1.5 \mathrm{~kg} / \mathrm{t})$

\begin{tabular}{|c|c|c|c|c|c|c|c|c|c|}
\hline \multirow{2}{*}{$\mathrm{DP}$} & \multirow{2}{*}{ Product } & \multirow{2}{*}{$\mathrm{Wt} \%$} & \multicolumn{3}{|c|}{ Grade, \% } & \multicolumn{3}{|c|}{ Recovery, \% } & \multirow{2}{*}{ SI } \\
\hline & & & $\mathrm{P}_{2} \mathrm{O}_{5}$ & $\mathrm{MgO}$ & $\mathrm{AI}$ & $\mathrm{P}_{2} \mathrm{O}_{5}$ & $\mathrm{MgO}$ & $\mathrm{AI}$ & \\
\hline \multirow{3}{*}{$2.5 \%$} & Float & 18.70 & 10.8 & 10.25 & 3.27 & 8.72 & 58.10 & 5.80 & \multirow{3}{*}{57.06} \\
\hline & Sink & 81.30 & 26.0 & 1.70 & 12.22 & 91.28 & 41.90 & 94.20 & \\
\hline & Feed & 100.00 & 23.16 & 3.30 & 10.55 & 100.00 & 100.00 & 100.00 & \\
\hline \multirow{3}{*}{$5 \%$} & Float & 18.38 & 11.3 & 10.33 & 3.95 & 8.73 & 58.38 & 6.76 & \multirow{3}{*}{57.86} \\
\hline & Sink & 81.62 & 26.6 & 1.66 & 12.28 & 91.27 & 41.62 & 93.24 & \\
\hline & Feed & 100.00 & 23.79 & 3.25 & 10.75 & 100.00 & 100.00 & 100.00 & \\
\hline \multirow{3}{*}{$10 \%$} & Float & 21.80 & 10.4 & 9.11 & 3.63 & 9.63 & 60.61 & 7.93 & \multirow{3}{*}{58.99} \\
\hline & Sink & 78.20 & 27.2 & 1.65 & 11.75 & 90.37 & 39.39 & 92.07 & \\
\hline & Feed & 100.00 & 23.54 & 3.28 & 9.98 & 100.00 & 100.00 & 100.00 & \\
\hline \multirow{3}{*}{$15 \%$} & Float & 19.11 & 11.5 & 9.98 & 4.3 & 9.20 & 58.08 & 7.76 & \multirow{3}{*}{57.48} \\
\hline & Sink & 80.89 & 26.8 & 1.70 & 12.08 & 90.80 & 41.92 & 92.24 & \\
\hline & Feed & 100.00 & 23.88 & 3.28 & 10.59 & 100.00 & 100.00 & 100.00 & \\
\hline
\end{tabular}


Table C-5 Effect of the ratio of TW to FAS-40A on dolomite flotation

(pH: 5.4, FAS-40A: 1.5 kg/t)

\begin{tabular}{|c|c|c|c|c|c|c|c|c|c|}
\hline \multirow{2}{*}{ TW } & \multirow{2}{*}{ Product } & \multirow{2}{*}{$\mathrm{Wt} \%$} & \multicolumn{3}{|c|}{ Grade, \% } & \multicolumn{3}{|c|}{ Recovery, \% } & \multirow{2}{*}{ SI } \\
\hline & & & $\mathrm{P}_{2} \mathrm{O}_{5}$ & $\mathrm{MgO}$ & AI & $\mathrm{P}_{2} \mathrm{O}_{5}$ & $\mathrm{MgO}$ & AI & \\
\hline \multirow{3}{*}{$2.5 \%$} & Float & 15.35 & 11.3 & 9.81 & 4.02 & 7.18 & 45.80 & 5.58 & \multirow{3}{*}{51.37} \\
\hline & Sink & 84.65 & 26.5 & 2.11 & 12.34 & 92.82 & 54.20 & 94.42 & \\
\hline & Feed & 100.00 & 24.17 & 3.29 & 11.06 & 100.00 & 100.00 & 100.00 & \\
\hline \multirow{3}{*}{$5 \%$} & Float & 11.90 & 10.4 & 9.89 & 3.57 & 5.22 & 37.01 & 4.10 & \multirow{3}{*}{46.19} \\
\hline & Sink & 88.10 & 25.5 & 2.27 & 11.27 & 94.78 & 62.99 & 95.90 & \\
\hline & Feed & 100.00 & 23.70 & 3.18 & 10.35 & 100.00 & 100.00 & 100.00 & \\
\hline \multirow{3}{*}{$10 \%$} & Float & 12.48 & 9.8 & 9.49 & 3.56 & 5.14 & 35.30 & 4.11 & \multirow{3}{*}{45.28} \\
\hline & Sink & 87.52 & 25.8 & 2.48 & 11.86 & 94.86 & 64.70 & 95.89 & \\
\hline & Feed & 100.00 & 23.80 & 3.36 & 10.82 & 100.00 & 100.00 & 100.00 & \\
\hline \multirow{3}{*}{$15 \%$} & Float & 12.21 & 9.41 & 9.89 & 3.31 & 4.86 & 38.28 & 3.74 & \multirow{3}{*}{47.54} \\
\hline & Sink & 87.79 & 25.6 & 2.22 & 11.84 & 95.14 & 61.72 & 96.26 & \\
\hline & Feed & 100.00 & 23.62 & 3.16 & 10.80 & 100.00 & 100.00 & 100.00 & \\
\hline \multirow{3}{*}{$30 \%$} & Float & 15.51 & 10.1 & 10.10 & 3.57 & 6.59 & 50.02 & 5.30 & \multirow{3}{*}{54.45} \\
\hline & Sink & 84.49 & 26.3 & 1.85 & 11.7 & 93.41 & 49.98 & 94.70 & \\
\hline & Feed & 100.00 & 23.79 & 3.13 & 10.44 & 100.00 & 100.00 & 100.00 & \\
\hline
\end{tabular}


Table C-6 Effect of FAS-40A dosages on dolomite flotation in the presence of surfactant DSS1 at pH 5.4

\begin{tabular}{|c|c|c|c|c|c|c|c|c|c|c|}
\hline \multirow{2}{*}{ FAS-40A } & \multirow{2}{*}{ DSS1 } & \multirow{2}{*}{ Product } & \multirow{2}{*}{$\mathrm{Wt} \%$} & \multicolumn{3}{|c|}{ Grade, \% } & \multicolumn{3}{|c|}{ Recovery, \% } & \multirow{2}{*}{ SI } \\
\hline & & & & $\mathrm{P}_{2} \mathrm{O}_{5}$ & $\mathrm{MgO}$ & $\mathrm{AI}$ & $\mathrm{P}_{2} \mathrm{O}_{5}$ & $\mathrm{MgO}$ & $\mathrm{AI}$ & \\
\hline \multirow{3}{*}{0.45} & \multirow{3}{*}{0.05} & Float & 9.67 & 8.79 & 10.45 & 4.22 & 3.63 & 30.98 & 3.88 & \multirow{3}{*}{42.78} \\
\hline & & Sink & 90.33 & 25 & 2.49 & 11.2 & 96.37 & 69.02 & 96.12 & \\
\hline & & Feed & 100.00 & 23.43 & 3.26 & 10.52 & 100.00 & 100.00 & 100.00 & \\
\hline \multirow{3}{*}{0.9} & \multirow{3}{*}{0.1} & Float & 14.20 & 7.43 & 11.31 & 3.7 & 4.58 & 49.94 & 5.03 & \multirow{3}{*}{55.47} \\
\hline & & Sink & 85.80 & 25.6 & 1.88 & 11.57 & 95.42 & 50.06 & 94.97 & \\
\hline & & Feed & 100.00 & 23.02 & 3.22 & 10.45 & 100.00 & 100.00 & 100.00 & \\
\hline \multirow{3}{*}{1.35} & \multirow{3}{*}{0.15} & Float & 17.68 & 8.15 & 11.27 & 3.51 & 6.22 & 61.61 & 5.69 & \multirow{3}{*}{61.72} \\
\hline & & Sink & 82.32 & 26.4 & 1.51 & 12.51 & 93.78 & 38.39 & 94.31 & \\
\hline & & Feed & 100.00 & 23.17 & 3.24 & 10.92 & 100.00 & 100.00 & 100.00 & \\
\hline \multirow{3}{*}{1.8} & \multirow{3}{*}{0.2} & Float & 20.40 & 8.84 & 11.30 & 3.31 & 7.99 & 69.52 & 6.02 & \multirow{3}{*}{64.07} \\
\hline & & Sink & 79.60 & 26.1 & 1.27 & 13.24 & 92.01 & 30.48 & 93.98 & \\
\hline & & Feed & 100.00 & 22.58 & 3.32 & 11.21 & 100.00 & 100.00 & 100.00 & \\
\hline \multirow{3}{*}{2.25} & \multirow{3}{*}{0.25} & Float & 22.56 & 9.84 & 10.68 & 3.22 & 9.76 & 74.15 & 6.54 & \multirow{3}{*}{65.40} \\
\hline & & Sink & 77.44 & 26.5 & 1.09 & 13.41 & 90.24 & 25.85 & 93.46 & \\
\hline & & Feed & 100.00 & 22.74 & 3.25 & 11.11 & 100.00 & 100.00 & 100.00 & \\
\hline \multirow{3}{*}{2.7} & \multirow{3}{*}{0.3} & Float & 23.05 & 10.5 & 10.61 & 3.11 & 10.51 & 74.82 & 6.30 & \multirow{3}{*}{65.46} \\
\hline & & Sink & 76.95 & 26.8 & 1.07 & 13.87 & 89.49 & 25.18 & 93.70 & \\
\hline & & Feed & 100.00 & 23.04 & 3.27 & 11.39 & 100.00 & 100.00 & 100.00 & \\
\hline
\end{tabular}


Table C-7 Effect of FAS-40A dosages on dolomite flotation in the presence of surfactant DP at pH 5.4

\begin{tabular}{|c|c|c|c|c|c|c|c|c|c|c|}
\hline \multirow{2}{*}{ FAS-40A } & \multirow{2}{*}{ DP } & \multirow{2}{*}{ Product } & \multirow{2}{*}{$\mathrm{Wt} \%$} & \multicolumn{3}{|c|}{ Grade, $\%$} & \multicolumn{3}{|c|}{ Recovery, \% } & \multirow{2}{*}{ SI } \\
\hline & & & & $\mathrm{P}_{2} \mathrm{O}_{5}$ & $\mathrm{MgO}$ & $\mathrm{AI}$ & $\mathrm{P}_{2} \mathrm{O}_{5}$ & $\mathrm{MgO}$ & $\mathrm{AI}$ & \\
\hline \multirow{3}{*}{0.45} & \multirow{3}{*}{0.05} & Float & 14.99 & 14 & 8.58 & 5.14 & 8.73 & 38.37 & 7.82 & \multirow{3}{*}{44.03} \\
\hline & & Sink & 85.01 & 25.8 & 2.43 & 10.69 & 91.27 & 61.63 & 92.18 & \\
\hline & & Feed & 100.00 & 24.03 & 3.35 & 9.86 & 100.00 & 100.00 & 100.00 & \\
\hline \multirow{3}{*}{0.9} & \multirow{3}{*}{0.1} & Float & 19.75 & 12.7 & 8.96 & 4.82 & 11.15 & 54.92 & 8.49 & \multirow{3}{*}{51.86} \\
\hline & & Sink & 80.25 & 24.9 & 1.81 & 12.78 & 88.85 & 45.08 & 91.51 & \\
\hline & & Feed & 100.00 & 22.49 & 3.22 & 11.21 & 100.00 & 100.00 & 100.00 & \\
\hline \multirow{3}{*}{1.35} & \multirow{3}{*}{0.15} & Float & 20.25 & 11.7 & 9.37 & 4.51 & 10.58 & 60.71 & 8.00 & \multirow{3}{*}{55.90} \\
\hline & & Sink & 79.75 & 25.1 & 1.54 & 13.17 & 89.42 & 39.29 & 92.00 & \\
\hline & & Feed & 100.00 & 22.39 & 3.13 & 11.42 & 100.00 & 100.00 & 100.00 & \\
\hline \multirow{3}{*}{1.8} & \multirow{3}{*}{0.2} & Float & 20.30 & 11.1 & 9.83 & 4.52 & 9.87 & 59.70 & 8.32 & \multirow{3}{*}{56.73} \\
\hline & & Sink & 79.70 & 25.8 & 1.69 & 12.69 & 90.13 & 40.30 & 91.68 & \\
\hline & & Feed & 100.00 & 22.82 & 3.34 & 11.03 & 100.00 & 100.00 & 100.00 & \\
\hline \multirow{3}{*}{2.25} & \multirow{3}{*}{0.25} & Float & 20.45 & 11.2 & 9.58 & 4.24 & 10.15 & 61.68 & 7.71 & \multirow{3}{*}{57.27} \\
\hline & & Sink & 79.55 & 25.5 & 1.53 & 13.05 & 89.85 & 38.32 & 92.29 & \\
\hline & & Feed & 100.00 & 22.58 & 3.18 & 11.25 & 100.00 & 100.00 & 100.00 & \\
\hline \multirow{3}{*}{2.7} & \multirow{3}{*}{0.3} & Float & 20.67 & 10.9 & 9.86 & 4.51 & 9.24 & 62.22 & 7.66 & \multirow{3}{*}{58.59} \\
\hline & & Sink & 79.33 & 25.7 & 1.56 & 13.06 & 90.76 & 37.78 & 92.34 & \\
\hline & & Feed & 100.00 & 22.83 & 3.28 & 11.40 & 100.00 & 100.00 & 100.00 & \\
\hline
\end{tabular}


Table C-8 Effect of FAS-40A dosages on dolomite flotation in the presence of surfactant TW at $\mathrm{pH} 5.4$

\begin{tabular}{|c|c|c|c|c|c|c|c|c|c|c|}
\hline \multirow{2}{*}{ FAS-40A } & \multirow{2}{*}{ TW } & \multirow{2}{*}{ Product } & \multirow{2}{*}{$\mathrm{Wt} \%$} & \multicolumn{3}{|c|}{ Grade, $\%$} & \multicolumn{3}{|c|}{ Recovery, \% } & \multirow{2}{*}{ SI } \\
\hline & & & & $\mathrm{P}_{2} \mathrm{O}_{5}$ & $\mathrm{MgO}$ & $\mathrm{AI}$ & $\mathrm{P}_{2} \mathrm{O}_{5}$ & $\mathrm{MgO}$ & $\mathrm{AI}$ & \\
\hline \multirow{3}{*}{0.45} & \multirow{3}{*}{0.05} & Float & 5.74 & 13.8 & 10.3 & 4.8 & 3.38 & 18.35 & 2.63 & \multirow{3}{*}{31.05} \\
\hline & & Sink & 94.26 & 24 & 2.79 & 10.8 & 96.62 & 81.65 & 97.37 & \\
\hline & & Feed & 100.00 & 23.41 & 3.22 & 10.46 & 100.00 & 100.00 & 100.00 & \\
\hline \multirow{3}{*}{0.9} & \multirow{3}{*}{0.1} & Float & 15.84 & 12 & 9.38 & 4.61 & 8.23 & 44.86 & 6.75 & \multirow{3}{*}{48.51} \\
\hline & & Sink & 84.16 & 25.2 & 2.17 & 11.99 & 91.77 & 55.14 & 93.25 & \\
\hline & & Feed & 100.00 & 23.11 & 3.31 & 10.82 & 100.00 & 100.00 & 100.00 & \\
\hline \multirow{3}{*}{1.35} & \multirow{3}{*}{0.15} & Float & 16.32 & 10.8 & 10.3 & 3.92 & 7.68 & 49.74 & 5.58 & \multirow{3}{*}{52.23} \\
\hline & & Sink & 83.68 & 25.3 & 2.03 & 12.93 & 92.32 & 50.26 & 94.42 & \\
\hline & & Feed & 100.00 & 22.93 & 3.38 & 11.46 & 100.00 & 100.00 & 100.00 & \\
\hline \multirow{3}{*}{1.8} & \multirow{3}{*}{0.2} & Float & 19.17 & 11.5 & 9.84 & 4.7 & 9.60 & 57.43 & 8.07 & \multirow{3}{*}{55.56} \\
\hline & & Sink & 80.83 & 25.7 & 1.73 & 12.7 & 90.40 & 42.57 & 91.93 & \\
\hline & & Feed & 100.00 & 22.98 & 3.28 & 11.17 & 100.00 & 100.00 & 100.00 & \\
\hline \multirow{3}{*}{2.25} & \multirow{3}{*}{0.25} & Float & 20.51 & 12.1 & 9.69 & 4.55 & 10.72 & 62.97 & 8.17 & \multirow{3}{*}{58.05} \\
\hline & & Sink & 79.49 & 26 & 1.47 & 13.2 & 89.28 & 37.03 & 91.83 & \\
\hline & & Feed & 100.00 & 23.15 & 3.16 & 11.43 & 100.00 & 100.00 & 100.00 & \\
\hline \multirow{3}{*}{2.7} & \multirow{3}{*}{0.3} & Float & 19.37 & 10.9 & 9.8 & 3.82 & 9.05 & 59.23 & 6.49 & \multirow{3}{*}{57.74} \\
\hline & & Sink & 80.63 & 26.3 & 1.62 & 13.22 & 90.95 & 40.77 & 93.51 & \\
\hline & & Feed & 100.00 & 23.32 & 3.20 & 11.40 & 100.00 & 100.00 & 100.00 & \\
\hline
\end{tabular}


Table C-9 Effect of CCS-500 dosages on dolomite flotation at pH 5.1

\begin{tabular}{|c|c|c|c|c|c|c|c|c|c|}
\hline \multirow{2}{*}{$\begin{array}{c}\mathrm{CCS}-500 \\
\mathrm{Kg} / \mathrm{t}\end{array}$} & \multirow{2}{*}{ Product } & \multirow{2}{*}{$\mathrm{Wt} \%$} & \multicolumn{3}{|c|}{ Grade, $\%$} & \multicolumn{3}{|c|}{ Recovery, \% } & \multirow{2}{*}{ SI } \\
\hline & & & $\mathrm{P}_{2} \mathrm{O}_{5}$ & $\mathrm{MgO}$ & Insol. & $\mathrm{P}_{2} \mathrm{O}_{5}$ & $\mathrm{MgO}$ & Insol. & \\
\hline \multirow{3}{*}{2.0} & Float & 35.08 & 16.60 & 7.00 & 6.08 & 24.32 & 76.52 & 19.88 & \multirow{3}{*}{55.34} \\
\hline & Sink & 64.92 & 27.91 & 1.16 & 13.24 & 75.68 & 23.48 & 80.12 & \\
\hline & Feed & 100.00 & 23.94 & 3.21 & 10.73 & 100.00 & 100.00 & 100.00 & \\
\hline \multirow{3}{*}{1.5} & Float & 30.84 & 15.57 & 7.54 & 5.28 & 20.33 & 71.73 & 15.19 & \multirow{3}{*}{55.62} \\
\hline & Sink & 69.16 & 27.20 & 1.32 & 13.14 & 79.67 & 28.27 & 84.81 & \\
\hline & Feed & 100.00 & 23.61 & 3.24 & 10.72 & 100.00 & 100.00 & 100.00 & \\
\hline \multirow{3}{*}{1} & Float & 24.18 & 15.45 & 7.75 & 4.86 & 15.93 & 59.81 & 11.46 & \multirow{3}{*}{51.62} \\
\hline & Sink & 75.82 & 26.00 & 1.66 & 11.98 & 84.07 & 40.19 & 88.54 & \\
\hline & Feed & 100.00 & 23.45 & 3.13 & 10.26 & 100.00 & 100.00 & 100.00 & \\
\hline \multirow{3}{*}{0.75} & Float & 19.03 & 15.82 & 7.66 & 5.67 & 12.73 & 45.46 & 10.07 & \multirow{3}{*}{44.98} \\
\hline & Sink & 80.97 & 25.50 & 2.16 & 11.90 & 87.27 & 54.54 & 89.93 & \\
\hline & Feed & 100.00 & 23.66 & 3.21 & 10.71 & 100.00 & 100.00 & 100.00 & \\
\hline \multirow{3}{*}{0.5} & Float & 11.75 & 15.49 & 8.19 & 4.94 & 7.71 & 30.13 & 5.28 & \multirow{3}{*}{37.68} \\
\hline & Sink & 88.25 & 24.70 & 2.53 & 11.79 & 92.29 & 69.87 & 94.72 & \\
\hline & Feed & 100.00 & 23.62 & 3.19 & 10.98 & 100.00 & 100.00 & 100.00 & \\
\hline
\end{tabular}

Table C-10 Effect of CCS-500 dosages on dolomite flotation at pH 5.1

\begin{tabular}{|c|c|c|c|c|c|c|c|c|c|}
\hline \multirow{2}{*}{$\begin{array}{c}\mathrm{CCS}-550 \\
\mathrm{Kg} / \mathrm{t}\end{array}$} & \multirow{2}{*}{ Product } & \multirow{2}{*}{$\mathrm{Wt} \%$} & \multicolumn{3}{|c|}{ Grade, $\%$} & \multicolumn{3}{|c|}{ Recovery, \% } & \multirow{2}{*}{ SI } \\
\hline & & & $\mathrm{P}_{2} \mathrm{O}_{5}$ & $\mathrm{MgO}$ & Insol. & $\mathrm{P}_{2} \mathrm{O}_{5}$ & $\mathrm{MgO}$ & Insol. & \\
\hline \multirow{3}{*}{1.5} & Float & 33.50 & 18.00 & 6.27 & 6.75 & 25.35 & 65.41 & 21.36 & \multirow{3}{*}{47.10} \\
\hline & Sink & 66.50 & 26.70 & 1.67 & 12.52 & 74.65 & 34.59 & 78.64 & \\
\hline & Feed & 100.00 & 23.79 & 3.21 & 10.59 & 100.00 & 100.00 & 100.00 & \\
\hline \multirow{3}{*}{1.0} & Float & 15.17 & 16.90 & 6.42 & 5.69 & 11.06 & 31.31 & 8.62 & \multirow{3}{*}{34.87} \\
\hline & Sink & 84.83 & 24.30 & 2.52 & 10.79 & 88.94 & 68.69 & 91.38 & \\
\hline & Feed & 33.50 & 18.00 & 6.27 & 6.75 & 25.35 & 65.41 & 21.36 & \\
\hline
\end{tabular}


Table C-11 Mixtures of FAS-40A and CCS-500 (or CCS-550) as collector at pH 5.1

\begin{tabular}{|c|c|c|c|c|c|c|c|c|c|c|}
\hline \multirow{2}{*}{ FAS-40A } & \multirow{2}{*}{ SS } & \multirow{2}{*}{ Product } & \multirow{2}{*}{$\mathrm{Wt} \%$} & \multicolumn{3}{|c|}{ Grade, $\%$} & \multicolumn{3}{|c|}{ Recovery, \% } & \multirow{2}{*}{ SI } \\
\hline & & & & $\mathrm{P}_{2} \mathrm{O}_{5}$ & $\mathrm{MgO}$ & Insol. & $\mathrm{P}_{2} \mathrm{O}_{5}$ & $\mathrm{MgO}$ & Insol. & \\
\hline \multirow{3}{*}{1.5} & \multirow{3}{*}{ CCS-550 } & Float & 22.23 & 12.00 & 9.43 & 4.59 & 11.35 & 65.81 & 9.15 & \multirow{3}{*}{59.95} \\
\hline & & Sink & 77.77 & 26.80 & 1.40 & 13.03 & 88.65 & 34.19 & 90.85 & \\
\hline & & Feed & 100.00 & 23.51 & 3.19 & 11.15 & 100.00 & 100.00 & 100.00 & \\
\hline \multirow{3}{*}{3.0} & \multirow{3}{*}{ CCS-500 } & Float & 22.51 & 12.26 & 9.66 & 4.06 & 11.66 & 66.21 & 8.33 & \multirow{3}{*}{60.10} \\
\hline & & Sink & 77.49 & 26.98 & 1.43 & 12.98 & 88.34 & 33.79 & 91.67 & \\
\hline & & Feed & 100.00 & 23.67 & 3.28 & 10.97 & 100.00 & 100.00 & 100.00 & \\
\hline
\end{tabular}

Table C-12 Effect of PA-31 dosages on dolomite flotation at pH 5.1

\begin{tabular}{|c|c|c|c|c|c|c|c|c|c|}
\hline \multirow{2}{*}{$\begin{array}{c}\mathrm{CCS}-500 \\
\mathrm{Kg} / \mathrm{t}\end{array}$} & \multirow{2}{*}{ Product } & \multirow{2}{*}{$\mathrm{Wt} \%$} & \multicolumn{3}{|c|}{ Grade, \% } & \multicolumn{3}{|c|}{ Recovery, \% } & \multirow{2}{*}{ SI } \\
\hline & & & $\mathrm{P}_{2} \mathrm{O}_{5}$ & $\mathrm{MgO}$ & Insol. & $\mathrm{P}_{2} \mathrm{O}_{5}$ & $\mathrm{MgO}$ & Insol. & \\
\hline \multirow{3}{*}{1.5} & Float & 17.80 & 10.76 & 8.97 & 3.92 & 8.20 & 54.68 & 6.30 & \multirow{3}{*}{55.62} \\
\hline & Sink & 82.20 & 26.10 & 1.61 & 12.63 & 91.80 & 45.32 & 93.70 & \\
\hline & Feed & 100.00 & 23.37 & 2.92 & 11.08 & 100.00 & 100.00 & 100.00 & \\
\hline \multirow{3}{*}{2.0} & Float & 19.21 & 11.02 & 8.72 & 3.66 & 9.01 & 59.52 & 6.22 & \multirow{3}{*}{58.11} \\
\hline & Sink & 80.79 & 26.45 & 1.41 & 13.11 & 90.99 & 40.48 & 93.78 & \\
\hline & Feed & 100.00 & 23.49 & 2.81 & 11.29 & 100.00 & 100.00 & 100.00 & \\
\hline \multirow{3}{*}{2.7} & Float & 21.53 & 11.07 & 8.59 & 3.53 & 10.26 & 66.03 & 6.68 & \multirow{3}{*}{60.81} \\
\hline & Sink & 78.48 & 26.60 & 1.21 & 13.48 & 89.74 & 33.97 & 93.32 & \\
\hline & Feed & 100.00 & 23.26 & 2.80 & 11.34 & 100.00 & 100.00 & 100.00 & \\
\hline
\end{tabular}




\section{APPENDIX D}

\section{Modified Packed Column Flotation Data}


Table D-1 Results of modified packed column flotation

\begin{tabular}{|c|c|c|c|c|c|c|c|c|c|c|c|c|c|c|c|}
\hline \multirow{2}{*}{ Run } & \multicolumn{4}{|c|}{ Coded conditions } & \multicolumn{4}{|c|}{ Natural conditions } & \multirow{2}{*}{ Product } & \multirow[b]{2}{*}{$\mathrm{Wt} \%$} & \multicolumn{2}{|c|}{ Grade, $\%$} & \multicolumn{2}{|c|}{ Recovery, \% } & \multirow{2}{*}{ SI } \\
\hline & $\mathrm{pH}^{1}$ & $\mathrm{CL}^{2}$ & $\mathrm{IF}^{3}$ & $\mathrm{AR}^{4}$ & $\mathrm{pH}$ & $\mathrm{CL}$ & IF & $\mathrm{AR}$ & & & $\mathrm{P}_{2} \mathrm{O}_{5}$ & $\mathrm{MgO}$ & $\mathrm{P}_{2} \mathrm{O}_{5}$ & $\mathrm{MgO}$ & \\
\hline \multirow{3}{*}{1} & \multirow{3}{*}{-1} & \multirow{3}{*}{-1} & \multirow{3}{*}{-1} & \multirow{3}{*}{-1} & \multirow{3}{*}{4.5} & \multirow{3}{*}{2} & \multirow{3}{*}{10} & \multirow{3}{*}{1.5} & Float & 3.40 & 18.80 & 4.15 & 2.48 & 10.24 & \multirow{3}{*}{23.41} \\
\hline & & & & & & & & & Sink & 96.60 & 26.06 & 1.28 & 97.52 & 89.76 & \\
\hline & & & & & & & & & Feed & 100.00 & 25.81 & 1.38 & 100.00 & 100.00 & \\
\hline \multirow{3}{*}{2} & \multirow{3}{*}{1} & \multirow{3}{*}{-1} & \multirow{3}{*}{-1} & \multirow{3}{*}{-1} & \multirow{3}{*}{5.5} & \multirow{3}{*}{2} & \multirow{3}{*}{10} & \multirow{3}{*}{1.5} & Float & 5.20 & 20.15 & 4.74 & 3.95 & 18.44 & \multirow{3}{*}{32.22} \\
\hline & & & & & & & & & Sink & 94.80 & 26.86 & 1.15 & 96.05 & 81.56 & \\
\hline & & & & & & & & & Feed & 100.00 & 26.51 & 1.34 & 100.00 & 100.00 & \\
\hline \multirow{3}{*}{3} & \multirow{3}{*}{-1} & & & & & & & & Float & 7.33 & 20.68 & 3.77 & 5.81 & 20.45 & \\
\hline & & 1 & -1 & -1 & 4.5 & 3 & 10 & 1.5 & Sink & 92.67 & 26.50 & 1.16 & 94.19 & 79.55 & 31.85 \\
\hline & & & & & & & & & Feed & 100.00 & 26.07 & 1.35 & 100.00 & 100.00 & \\
\hline & & & & & & & & & Float & 3.80 & 20.30 & 4.93 & 2.98 & 13.39 & \\
\hline 4 & -1 & -1 & 1 & -1 & 4.5 & 2 & 20 & 1.5 & Sink & 96.20 & 26.08 & 1.26 & 97.02 & 86.61 & 27.05 \\
\hline & & & & & & & & & Feed & 100.00 & 25.86 & 1.40 & 100.00 & 100.00 & \\
\hline & & & & & & & & & Float & 5.39 & 19.46 & 4.04 & 3.97 & 15.76 & \\
\hline 5 & -1 & -1 & -1 & 1 & 4.5 & 2 & 10 & 2.1 & Sink & 94.61 & 26.84 & 1.23 & 96.03 & 84.24 & 29.05 \\
\hline & & & & & & & & & Feed & 100.00 & 26.44 & 1.38 & 100.00 & 100.00 & \\
\hline & & & & & & & & & Float & 11.21 & 21.47 & 3.66 & 9.22 & 29.52 & \\
\hline & & & & & & & & & Sink & 88.79 & 26.68 & 1.10 & 90.78 & 70.48 & \\
\hline 6 & 1 & 1 & -1 & -1 & 5.5 & 3 & 10 & 1.5 & Feed & 100.00 & 26.10 & 1.39 & 100.00 & 100.00 & 36.95 \\
\hline & & & & & & & & & Sink & 92.98 & 26.81 & 1.20 & 94.58 & 80.35 & \\
\hline & & & & & & & & & Feed & 100.00 & 26.36 & 1.39 & 100.00 & 100.00 & \\
\hline
\end{tabular}

1. Flotation $\mathrm{pH} ; 2$. Collector dosage; 3 . Froth height; 4. Airflow rate. 
Table D-1 Results of modified packed column flotation (cont'd)

\begin{tabular}{|c|c|c|c|c|c|c|c|c|c|c|c|c|c|c|c|}
\hline \multirow{2}{*}{ Run } & \multicolumn{4}{|c|}{ Coded conditions } & \multicolumn{4}{|c|}{ Natural conditions } & \multirow{2}{*}{ Product } & \multirow[b]{2}{*}{$\mathrm{Wt} \%$} & \multicolumn{2}{|c|}{ Grade, $\%$} & \multicolumn{2}{|c|}{ Recovery, \% } & \multirow{2}{*}{ SI } \\
\hline & $\mathrm{pH}$ & $\mathrm{CL}$ & $\mathrm{IF}$ & $\mathrm{AR}$ & $\mathrm{pH}$ & $\mathrm{CL}$ & $\mathrm{IF}$ & $\mathrm{AR}$ & & & $\mathrm{P}_{2} \mathrm{O}_{5}$ & $\mathrm{MgO}$ & $\mathrm{P}_{2} \mathrm{O}_{5}$ & $\mathrm{MgO}$ & \\
\hline \multirow{3}{*}{7} & \multirow{3}{*}{-1} & \multirow{3}{*}{1} & \multirow{3}{*}{1} & \multirow{3}{*}{-1} & \multirow{3}{*}{4.5} & \multirow{3}{*}{3} & \multirow{3}{*}{20} & \multirow{3}{*}{1.5} & Float & 5.39 & 19.46 & 4.04 & 3.97 & 15.76 & \multirow{3}{*}{29.05} \\
\hline & & & & & & & & & Sink & 94.61 & 26.84 & 1.23 & 96.03 & 84.24 & \\
\hline & & & & & & & & & Feed & 100.00 & 26.44 & 1.38 & 100.00 & 100.00 & \\
\hline \multirow{3}{*}{8} & \multirow{3}{*}{-1} & \multirow{3}{*}{-1} & \multirow{3}{*}{1} & \multirow{3}{*}{1} & \multirow{3}{*}{4.5} & \multirow{3}{*}{2} & \multirow{3}{*}{20} & \multirow{3}{*}{2.1} & Float & 5.12 & 17.50 & 4.40 & 3.48 & 17.48 & \multirow{3}{*}{31.35} \\
\hline & & & & & & & & & Sink & 94.88 & 26.19 & 1.12 & 96.52 & 82.52 & \\
\hline & & & & & & & & & Feed & 100.00 & 25.75 & 1.29 & 100.00 & 100.00 & \\
\hline \multirow{3}{*}{9} & \multirow{3}{*}{-1} & \multirow{3}{*}{1} & & & & & & & Float & 8.14 & 18.10 & 4.77 & 5.67 & 26.88 & \\
\hline & & & -1 & 1 & 4.5 & 3 & 10 & 2.1 & Sink & 91.86 & 26.70 & 1.15 & 94.33 & 73.12 & 38.52 \\
\hline & & & & & & & & & Feed & 100.00 & 26.00 & 1.44 & 100.00 & 100.00 & \\
\hline & & & & & & & & & Float & 4.23 & 19.67 & 3.92 & 3.20 & 12.00 & \\
\hline 10 & 1 & -1 & 1 & -1 & 5.5 & 2 & 20 & 1.5 & Sink & 95.77 & 26.30 & 1.27 & 96.80 & 88.00 & 24.95 \\
\hline & & & & & & & & & Feed & 100.00 & 26.02 & 1.38 & 100.00 & 100.00 & \\
\hline & & & & & & & & & Float & 9.61 & 22.08 & 2.87 & 8.10 & 19.84 & \\
\hline 11 & 1 & -1 & -1 & 1 & 5.5 & 2 & 10 & 2.1 & Sink & 90.39 & 26.65 & 1.23 & 91.90 & 80.16 & 28.27 \\
\hline & & & & & & & & & Feed & 100.00 & 26.21 & 1.39 & 100.00 & 100.00 & \\
\hline & & & & & & & & & Float & 9.16 & 20.31 & 3.87 & 7.08 & 26.07 & \\
\hline 12 & 1 & 1 & 1 & -1 & 5.5 & 3 & 20 & 1.5 & Sink & 90.84 & 26.88 & 1.11 & 92.92 & 73.93 & 36.3 \\
\hline & & & & & & & & & Feed & 100.00 & 26.28 & 1.36 & 100.00 & 100.00 & \\
\hline
\end{tabular}


Table D-1 Results of modified packed column flotation (cont'd)

\begin{tabular}{|c|c|c|c|c|c|c|c|c|c|c|c|c|c|c|c|}
\hline \multirow{2}{*}{ Run } & \multicolumn{4}{|c|}{ Coded conditions } & \multicolumn{4}{|c|}{ Natural conditions } & \multirow{2}{*}{ Product } & \multirow[b]{2}{*}{$\mathrm{Wt} \%$} & \multicolumn{2}{|c|}{ Grade, $\%$} & \multicolumn{2}{|c|}{ Recovery, \% } & \multirow{2}{*}{ SI } \\
\hline & $\mathrm{pH}$ & $\mathrm{CL}$ & $\mathrm{IF}$ & $\mathrm{AR}$ & $\mathrm{pH}$ & $\mathrm{CL}$ & $\mathrm{IF}$ & $\mathrm{AR}$ & & & $\mathrm{P}_{2} \mathrm{O}_{5}$ & $\mathrm{MgO}$ & $\mathrm{P}_{2} \mathrm{O}_{5}$ & $\mathrm{MgO}$ & \\
\hline \multirow{3}{*}{13} & \multirow{3}{*}{-1} & \multirow{3}{*}{1} & \multirow{3}{*}{1} & \multirow{3}{*}{1} & \multirow{3}{*}{4.5} & \multirow{3}{*}{3} & \multirow{3}{*}{20} & \multirow{3}{*}{2.1} & Float & 6.90 & 19.87 & 5.03 & 5.17 & 24.01 & \multirow{3}{*}{36.61} \\
\hline & & & & & & & & & Sink & 93.10 & 27.00 & 1.18 & 94.83 & 75.99 & \\
\hline & & & & & & & & & Feed & 100.00 & 26.51 & 1.45 & 100.00 & 100.00 & \\
\hline \multirow{3}{*}{14} & \multirow{3}{*}{1} & \multirow{3}{*}{-1} & \multirow{3}{*}{1} & \multirow{3}{*}{1} & \multirow{3}{*}{5.5} & \multirow{3}{*}{2} & \multirow{3}{*}{20} & \multirow{3}{*}{2.1} & Float & 7.11 & 21.69 & 3.01 & 5.92 & 15.18 & \multirow{3}{*}{25.27} \\
\hline & & & & & & & & & Sink & 92.89 & 26.38 & 1.29 & 94.08 & 84.82 & \\
\hline & & & & & & & & & Feed & 100.00 & 26.05 & 1.41 & 100.00 & 100.00 & \\
\hline \multirow{3}{*}{15} & \multirow{3}{*}{1} & \multirow{3}{*}{1} & & & & & & & Float & 13.11 & 22.56 & 3.77 & 11.20 & 37.45 & \\
\hline & & & -1 & 1 & 5.5 & 3 & 10 & 2.1 & Sink & 86.89 & 26.99 & 0.95 & 88.80 & 62.55 & 41.81 \\
\hline & & & & & & & & & Feed & 100.00 & 26.41 & 1.32 & 100.00 & 100.00 & \\
\hline & & & & & & & & & Float & 10.55 & 22.13 & 3.94 & 8.83 & 32.17 & \\
\hline 16 & 1 & 1 & 1 & 1 & 5.5 & 3 & 20 & 2.1 & Sink & 89.45 & 26.95 & 0.98 & 91.17 & 67.83 & 39.91 \\
\hline & & & & & & & & & Feed & 100.00 & 26.44 & 1.29 & 100.00 & 100.00 & \\
\hline & & & & & & & & & Float & 8.65 & 21.98 & 4.21 & 7.23 & 27.90 & \\
\hline 17 & 1 & 0 & 0 & 0 & 5.5 & 2.5 & 15 & 1.8 & Sink & 91.35 & 26.72 & 1.03 & 92.77 & 72.10 & 37.73 \\
\hline & & & & & & & & & Feed & 100.00 & 26.31 & 1.31 & 100.00 & 100.00 & \\
\hline & & & & & & & & & Float & 7.51 & 21.17 & 3.95 & 6.05 & 21.96 & \\
\hline 18 & -1 & 0 & 0 & 0 & 4.5 & 2.5 & 15 & 1.8 & Sink & 92.49 & 26.71 & 1.14 & 93.95 & 78.04 & 33.3 \\
\hline & & & & & & & & & Feed & 100.00 & 26.29 & 1.35 & 100.00 & 100.00 & \\
\hline
\end{tabular}


Table D-1 Results of modified packed column flotation (cont'd)

\begin{tabular}{|c|c|c|c|c|c|c|c|c|c|c|c|c|c|c|c|}
\hline \multirow{2}{*}{ Run } & \multicolumn{4}{|c|}{ Coded conditions } & \multicolumn{4}{|c|}{ Natural conditions } & \multirow{2}{*}{ Product } & \multirow[b]{2}{*}{$\mathrm{Wt} \%$} & \multicolumn{2}{|c|}{ Grade, $\%$} & \multicolumn{2}{|c|}{ Recovery, \% } & \multirow{2}{*}{ SI } \\
\hline & $\mathrm{pH}$ & $\mathrm{CL}$ & IF & $\mathrm{AR}$ & $\mathrm{pH}$ & $\mathrm{CL}$ & IF & $\mathrm{AR}$ & & & $\mathrm{P}_{2} \mathrm{O}_{5}$ & $\mathrm{MgO}$ & $\mathrm{P}_{2} \mathrm{O}_{5}$ & $\mathrm{MgO}$ & \\
\hline \multirow{3}{*}{19} & \multirow{3}{*}{0} & \multirow{3}{*}{1} & \multirow{3}{*}{0} & \multirow{3}{*}{0} & \multirow{3}{*}{5} & \multirow{3}{*}{3} & \multirow{3}{*}{15} & \multirow{3}{*}{1.8} & Float & 9.01 & 22.00 & 4.01 & 7.53 & 26.18 & \multirow{3}{*}{35.82} \\
\hline & & & & & & & & & Sink & 90.99 & 26.77 & 1.12 & 92.47 & 73.82 & \\
\hline & & & & & & & & & Feed & 100.00 & 26.34 & 1.38 & 100.00 & 100.00 & \\
\hline \multirow{3}{*}{20} & \multirow{3}{*}{0} & \multirow{3}{*}{-1} & \multirow{3}{*}{0} & \multirow{3}{*}{0} & \multirow{3}{*}{5} & \multirow{3}{*}{2} & \multirow{3}{*}{15} & \multirow{3}{*}{1.8} & Float & 6.95 & 20.54 & 3.98 & 5.43 & 20.19 & \multirow{3}{*}{32.19} \\
\hline & & & & & & & & & Sink & 93.05 & 26.72 & 1.18 & 94.57 & 79.81 & \\
\hline & & & & & & & & & Feed & 100.00 & 26.29 & 1.37 & 100.00 & 100.00 & \\
\hline \multirow{3}{*}{21} & \multirow{3}{*}{0} & \multirow{3}{*}{0} & & & & & & & Float & 7.22 & 21.33 & 3.81 & 5.83 & 19.51 & \\
\hline & & & 1 & 0 & 5 & 2.5 & 20 & 1.8 & Sink & 92.78 & 26.81 & 1.22 & 94.17 & 80.49 & 30.97 \\
\hline & & & & & & & & & Feed & 100.00 & 26.41 & 1.41 & 100.00 & 100.00 & \\
\hline & & & & & & & & & Float & 8.29 & 21.26 & 3.77 & 6.68 & 22.98 & \\
\hline 22 & 0 & 0 & -1 & 0 & 5 & 2.5 & 15 & 1.8 & Sink & 91.71 & 26.84 & 1.14 & 93.32 & 77.02 & 33.68 \\
\hline & & & & & & & & & Feed & 100.00 & 26.38 & 1.36 & 100.00 & 100.00 & \\
\hline & & & & & & & & & Float & 8.61 & 21.64 & 3.76 & 7.02 & 23.46 & \\
\hline 23 & 0 & 0 & 0 & 1 & 5 & 2.5 & 20 & 2.1 & Sink & 91.39 & 27.00 & 1.16 & 92.98 & 76.54 & 33.86 \\
\hline & & & & & & & & & Feed & 100.00 & 26.54 & 1.38 & 100.00 & 100.00 & \\
\hline & & & & & & & & & Float & 7.11 & 20.69 & 3.85 & 5.56 & 20.58 & \\
\hline 24 & 0 & 0 & 0 & -1 & 5 & 2.5 & 20 & 1.5 & Sink & 92.89 & 26.91 & 1.14 & 94.44 & 79.42 & 32.57 \\
\hline & & & & & & & & & Feed & 100.00 & 26.47 & 1.33 & 100.00 & 100.00 & \\
\hline
\end{tabular}


Table D-1 Results of modified packed column flotation (cont'd)

\begin{tabular}{|c|c|c|c|c|c|c|c|c|c|c|c|c|c|c|c|}
\hline \multirow{2}{*}{ Run } & \multicolumn{4}{|c|}{ Coded conditions } & \multicolumn{4}{|c|}{ Natural conditions } & \multirow{2}{*}{ Product } & \multirow[b]{2}{*}{$\mathrm{Wt} \%$} & \multicolumn{2}{|c|}{ Grade, $\%$} & \multicolumn{2}{|c|}{ Recovery, \% } & \multirow{2}{*}{ SI } \\
\hline & $\mathrm{pH}$ & $\mathrm{CL}$ & IF & AR & $\mathrm{pH}$ & $\mathrm{CL}$ & IF & AR & & & $\mathrm{P}_{2} \mathrm{O}_{5}$ & $\mathrm{MgO}$ & $\mathrm{P}_{2} \mathrm{O}_{5}$ & $\mathrm{MgO}$ & \\
\hline \multirow{3}{*}{25} & \multirow{3}{*}{0} & \multirow{3}{*}{0} & \multirow{3}{*}{0} & \multirow{3}{*}{0} & \multirow{3}{*}{5} & \multirow{3}{*}{2} & \multirow{3}{*}{20} & \multirow{3}{*}{1.8} & Float & 6.22 & 20.15 & 4.11 & 4.77 & 17.88 & \multirow{3}{*}{30.43} \\
\hline & & & & & & & & & Sink & 93.78 & 26.70 & 1.25 & 95.23 & 82.12 & \\
\hline & & & & & & & & & Feed & 100.00 & 26.29 & 1.43 & 100.00 & 100.00 & \\
\hline \multirow{3}{*}{26} & \multirow{3}{*}{0} & \multirow{3}{*}{0} & \multirow{3}{*}{0} & \multirow{3}{*}{0} & \multirow{3}{*}{5} & \multirow{3}{*}{2} & \multirow{3}{*}{20} & \multirow{3}{*}{1.8} & Float & 7.02 & 20.34 & 3.89 & 5.42 & 19.65 & \multirow{3}{*}{31.66} \\
\hline & & & & & & & & & Sink & 92.98 & 26.81 & 1.20 & 94.58 & 80.35 & \\
\hline & & & & & & & & & Feed & 100.00 & 26.36 & 1.39 & 100.00 & 100.00 & \\
\hline
\end{tabular}




\section{VITA}

\section{PERSONAL}

Zhengxing Gu was born in September 11, 1956 in Jiangsu, China

\section{EDUCATION}

1978/1982: Central-South University of Technology, Changsha, Hunan, China, B.S. in Mineral Engineering;

2000/2002: West Virginia University, West Virginia, U.S.A., M.S. in Mineral Processing;

2002/2007: West Virginia University, West Virginia, U.S.A., Ph.D. in Mineral Processing.

\section{WORK EXPERIENCE}

1982-1991: Research Engineer, Lianyungang Design and Research Institute, China;

1992-1999: Senior Research Engineer, Lianyungang Design and Research Institute, China;

2000-2007: Graduate Research Assistant, Department of Mining Engineering, West Virginia University, U.S.A.

\section{SELECTED PUBLICATIONS}

Felicia Peng, and Zhengxing Gu, 2006, "Froth Phase Stability in Fine Dolomitic Phosphate Column Flotation”, SME Annual Conference, St. Louis, MO., March 26-29.

Felicia F. Peng and Zhengxing Gu, 2005, "Processing Florida Dolomitic Phosphate Pebble in Double Reverse Fine Flotation Process", Journal of Minerals and Metallurgical Processing, Vol. 22, No. 1, p.23-30.

Zhengxing Gu, Shibo Zheng, Wenyi Song and Felicia Peng, 2004, "Beneficiation of Sedimentary Dolomitic Phosphate Ore by Dense Medium Separation and Flotation", $4^{\text {th }}$ International Conference of Phosphate Beneficiation, Miami, FL. Dec. 5-10.

Zhengxing Gu and Zhizhong Gao, 1999, "Chapter 13, Beneficiation of Florida Dolomitic Phosphate Pebble with Fine Particle Flotation Technology", Beneficiation of Phosphate: Advances in Research and Practice, p.155-162. 